\title{
A recepção da poesia japonesa em Portugal
}

\section{Versão corrigida}

Tese apresentada como pré-requisito para a obtenção do título de doutor em Literatura Portuguesa pelo programa de pós-graduação em Letras da Faculdade de Filosofia, Letras e Ciências Humanas (FFLCH) da Universidade de São Paulo.

Doutorando: Claudio Alexandre de Barros Teixeira

Orientador: prof. dr. José Horácio de Almeida Nascimento Costa 


\section{AGRADECIMENTOS}

Ao meu orientador, Horácio Costa, pela leitura atenta e sugestões de pesquisa. A Simone Homem de Mello, pela leitura paciente deste trabalho e preciosos comentários. Ao Centro de Referência Haroldo de Campos, onde consultei obras de R. H. Blyth, Octavio Paz, Armando Martins Janeira e diversos outros autores citados nesta tese. Aos professores Antônio Vicente Seraphim Pietroforte, Ida Alves, Susanna Busato e Álvaro Faleiros, que fizeram parte de minha banca de defesa, realizada no dia 11 de dezembro de 2014, na Universidade de São Paulo. 
"Uma semiótica da recepção deve, fundamentalmente, tratar o receptor como um interpretante. O receptor não é alguém que recebe algo, nem está somente em estado passivo: em termos ótimos, ele deveria ser um coautor da informação. Haveria assim toda uma margem para que esse receptor, instigado pela criatividade do produtor (caso se tratasse de um produtor criativo), desse uma resposta criativa à mensagem, fizesse a crítica dessa mensagem. (...) Entendido como interpretante, o receptor é parte do processo sígnico e de todas as possibilidades de desdobramento daquela semiose ilimitada, como diz Umberto Eco."

(Haroldo de Campos, em entrevista concedida a Horácio Costa, publicada como apêndice ao livro Depoimentos de oficina - São Paulo: Unimarco, 2002, p. 83.) 


\section{SUMÁRIO}

Resumo

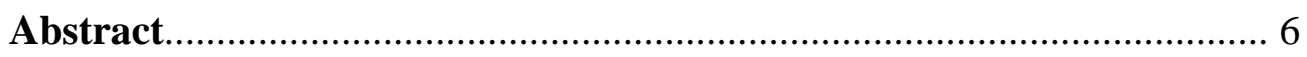

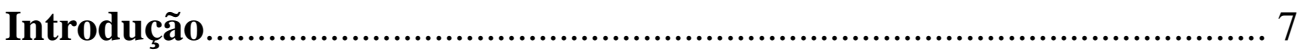

Capítulo I: A poesia japonesa: formas estruturais e referências culturais

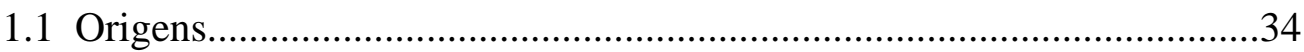

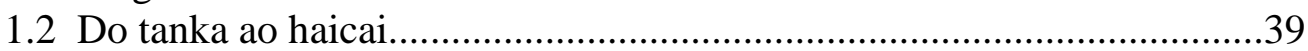

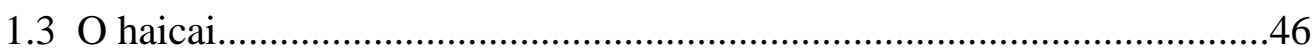

1.4 De Bashô a Shiki................................................................................ 53

1.5. O caráter visual da poesia japonesa..........................................................56

Capítulo II: A recepção da poesia japonesa em Portugal do século XVI até a Restauração Meiji

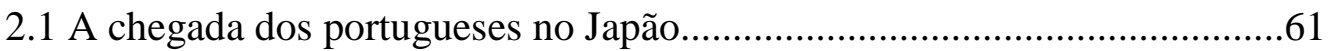

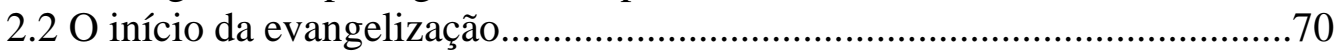

2.3 Relatos dos missionários portugueses sobre o Japão...................................75

2.4 A expulsão dos missionários no Período Tokugawa ..................................78

2.5 A Restauração Meiji e o diálogo cultural com o Ocidente...........................84

2.6 Wenceslau de Moraes, intérprete da cultura japonesa.................................86

$2.7 \mathrm{O}$ caso chinês de Camilo Pessanha

\section{Capítulo III: O diálogo criativo luso-japonês na contemporaneidade}

3.1 Armando Martins Janeira e o teatro lírico japonês.......................................100

3.2 Casimiro de Brito: o "rigor e a claridade enigmática do pensamento" ......114

3.3 Herberto Helder e o princípio da estranheza................................................136

3.4 Ana Hatherly e a reinvenção da escrita.....................................................147

3.5 A erotografia poética de Melo e Castro......................................................159

3.6 A "secura verde" de Albano Martins........................................................171

3.7 O branco no branco: a epifania de Eugênio de Andrade.............................180

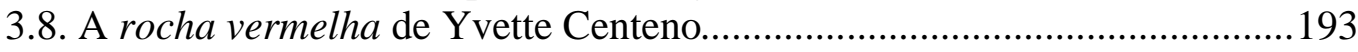

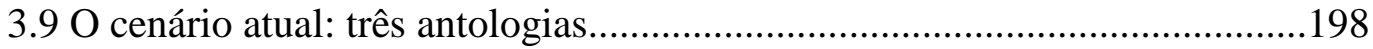

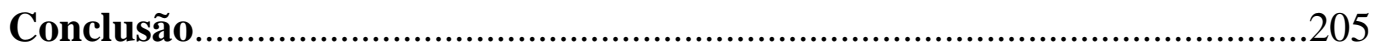

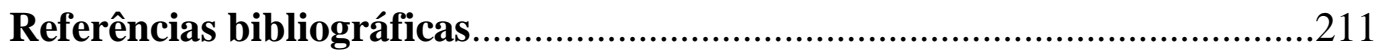




\section{RESUMO}

A recepção da poesia japonesa em Portugal é um estudo sobre o diálogo literário entre os autores portugueses e a tradição lírica da Terra do Sol Nascente. Iniciado no século XVI, esse intercâmbio motivou extensa produção de cartas, diários, relatos de viagem e obras de caráter filológico até a expulsão dos missionários cristãos, ocorrida durante o Período Tokugawa (1603-1867), que interrompeu todas as atividades comerciais, culturais e mesmo diplomáticas entre o arquipélago japonês e Portugal.

Com a Restauração Meiji, iniciada na segunda metade do século XIX, o diálogo é restabelecido, em um contexto internacional de crescente interesse europeu pela cultura japonesa, que pode ser avaliada pelas obras publicadas no período por autores como os franceses Edmond de Goncourt e Pierre Loti, o britânico Basil Chamberlain, o norteamericano Lafcadio Hearn e o português Wenceslau de Moraes, este último autor de numerosos livros, como Relance da alma japonesa, Daí Nippon e O culto do chá. Wenceslau de Moraes traça um amplo panorama da civilização japonesa, comentando desde a religião, a moral, a política, a vida cotidiana até as formas poéticas praticadas na literatura japonesa, realizando as primeiras traduções de haicais para o nosso idioma.

A recepção criativa da poesia japonesa em Portugal, porém, acontecerá apenas na segunda metade do século XX, quando poetas como Herberto Helder, Casimiro de Brito, Ana Hatherly, E. M. de Melo e Castro, Eugênio de Andrade, Albano Martins e Yvette Centeno recebem a influência da caligrafia artística japonesa, dos enigmáticos koans (公案). e da extrema concisão e imagética do haicai, desenvolvendo a partir daí composições autônomas, relacionadas com as preocupações formais da época, e em especial com o movimento da Poesia Experimental Portuguesa (PO-EX). Nosso propósito é estudar como cada um desses autores recebeu e transformou o influxo da tradição literária japonesa, mesclada a seus projetos literários e mitologias pessoais. 


\begin{abstract}
The reception of Japanese poetry in Portugal is a study of the literary dialogue between Portuguese authors and the lyrical tradition of the Land of the Rising Sun. Started in the sixteenth century, this exchange prompted extensive production of letters, diaries , travel accounts and works of philological character until the expulsion of Christian missionaries, which occurred during the Tokugawa Period (1603-1867), when all commercial, cultural and even diplomatic activities between the Japanese archipelago and Portugal ceased.

With the Meiji Restoration, which started in the second half of the nineteenth century, the dialog was restored in an international context of increasing European interest in Japanese culture, which can be evaluated by through works published in the period by such authors as the Frenchmen Edmond de Goncourt and Pierre Loti, the Englishman Basil Chamberlain, the American Lafcadio Hearn and the Portuguese Wenceslas de Moraes. This last author published such booksas Glimpse of the Japanese soul and Nippon Hence the cult of tea. Wenceslas de Moraes paints a broad picture of Japanese civilization, from religion, morality, politics and everyday life to the poetic forms practiced in Japanese literature. He also did the first translations of haiku into our language.

The creative reception of Japanese poetry in Portugal, however, take place only in the second half of the twentieth century, when poets like Herbert Helder, Casimiro de Brito, Ana Hatherly , EM de Melo e Castro, Eugenio de Andrade, Albano Martins and Yvette Centeno receive the influence of the Japanese Art of callygraphy, of the enigmatic koans and of the extreme concision and imagery of haiku. From these sources, poets developed autonomous compositions related to the formal concerns of the time, especially with the movement of Portuguese Experimental Poetry $(P O-E X)$. Our purpose is to study how each of these authors has received and transformed the influx of Japanese literary tradition, blending it into his or her literary projects and personal mythologies.
\end{abstract}




\section{INTRODUÇÃO}

Não existe imagem, não existe senão relação entre imagens.

— Jean Luc Godard ${ }^{1}$

Nesta Introdução, vamos discutir conceitos teóricos relacionados à tradução como recriação - ou reimaginação - dos textos originais, ação textual crítico-criativa similar à heteronímia ou às máscaras dramáticas (personae) de Ezra Pound, e ainda alguns tópicos da Teoria da Recepção, que orientam a abordagem adotada neste trabalho. Consideramos tal discussão relevante porque utilizamos essas ferramentas interpretativas ao longo da tese, na análise de poemas extraídos do cânone japonês e redimensionados em outro território linguístico e cultural - o da literatura portuguesa por poetas-tradutores como Herberto Helder e Casimiro de Brito. Em seguida, comentaremos o aspecto visual e analógico da escrita ideográfica à luz do pensamento e da prática poética das vanguardas europeias, e por fim apresentaremos, de modo sucinto, as estratégias de recepção criativa da poesia japonesa desenvolvidas na obra dos autores portugueses estudados no presente volume.

A poesia e as artes visuais japonesas exerceram fecunda influência na criação literária portuguesa na segunda metade do século XX, em consonância com as pesquisas formais da vanguarda, notadamente nos poetas reunidos em torno do movimento da Poesia Experimental Portuguesa (PO-EX), como Ana Hatherly e E. M. de Melo e Castro. A relação entre escrita poética e visualidade, a extrema concisão formal, próxima a um esvaziamento da linguagem, o princípio da analogia, a justaposição de imagens do ideograma e a subversão do sentido pelo emprego de uma lógica nãoaristotélica, mais afeita ao humor e ao paradoxo, são alguns tópicos da arte poética

\footnotetext{
${ }^{1}$ Suplemento Literário de Minas Gerais (Belo Horizonte, fev./2011).
} 
japonesa que estarão presentes em obras como os Ideogramas (1962) de Melo e Castro, a Teoria das cores (1963) de Herberto Helder e os Mapas da imaginação e da memória (1973) de Ana Hatherly. Esse diálogo criativo aconteceu num momento histórico em que o Ocidente vivia uma nova relação afetiva com a cultura japonesa, iniciada no segundo pós-guerra, que incluía o apreço pelo zen-budismo, pela cerimônia do chá, pelos arranjos florais e outras artes tradicionais do Império do Sol Nascente, divulgadas na Europa e nos Estados Unidos por autores como Daisetz Teitaro Sukuzi, Taisen Deshimaru, Allan Watts e Reginald Horace Blyth. Traduções de poesia japonesa circulavam há bastante tempo e o haicai era praticado em toda parte desde a década de 1920 por autores como o mexicano José Juan Tablada, o italiano Giuseppe Ungaretti, o francês Julien Vocance, o grego Giorgos Seféris, o brasileiro Guilherme de Almeida, o argentino Jorge Luís Borges. Nas décadas de 1950-1960, a forma do terceto japonês foi popularizada pelos autores beats norte-americanos, especialmente Gary Snyder, Allen Ginsberg e Jack Kerouac (este último, autor de Book of haikus e Dharma pops, traduzidos no Brasil por Claudio Willer no volume intitulado Livro de haicais $^{2}$ ). A singularidade da recepção criativa portuguesa, que motivou o presente trabalho, consiste em sua compreensão do íntimo relacionamento entre poesia, pintura, gestualidade e caligrafia, bem como na importância do pensamento analógico para a expressão poética, vetores que conciliam a prática japonesa do verso com a experimentação da vanguarda.

Claro: o terceto tradicional de métrica próxima à redondilha também é praticado na literatura portuguesa, com refinado despojamento semântico e invenção imagética, por autores como Casimiro de Brito, Albano Martins, Eugênio de Andrade e Yvette Centeno, que serão estudados nos próximos capítulos, bem como a gesta tradutória dos argonautas lusos que verteram para a língua de Camões os delicados cromos textuais de

\footnotetext{
${ }^{2}$ KEROUAC, Jack. Livro de haicais. Tradução: Claudio Willer. Porto Alegre: L\&PM, 2013.
} 
Bashô e seus discípulos - aventura empreendida por Herberto Helder e Casimiro de Brito. Adotando um ponto de vista poundiano, tratamos as traduções poéticas como obras literárias de valor análogo à produção dos próprios poetas-tradutores, situadas num território próximo ao da máscara dramática ou heteronímia. Invocamos, em defesa dessa abordagem, Haroldo de Campos, para quem "a tradução é também uma persona através da qual fala a tradição. Nesse sentido, como a paródia, ela é também um 'canto paralelo', um diálogo não apenas com a voz do original, mas com outras vozes textuais" (CAMPOS, 2013: 191). Sob essa perspectiva, a tradução pode ser compreendida como modalidade da crítica literária, que "supõe uma escolha, orienta-se por um projeto de leitura, a partir do presente de criação, do passado de cultura" (idem, 136). Conforme Albrecht Fabri, "toda tradução é crítica" porque "nasce da deficiência da sentença", da sua "insuficiência para valer por si mesma" (in CAMPOS, 2013: 2): o original só existe em estado de latência, para as múltiplas interpretações criativas do leitor-tradutor. Neste sentido, um haicai de Bashô traduzido por Casimiro de Brito não nos revela apenas o "sentido" 3 " do texto japonês, mas também a poética do tradutor, ele próprio hábil haicaísta; de modo similar, outra tradução do mesmo poema realizada por Herberto Helder pode sugerir ao leitor alguns elementos essenciais da poesia de $\mathrm{HH}$, como o pensamento analógico e a estética da metamorfose ${ }^{4}$. A comparação entre as soluções encontradas por diferentes poetas-tradutores para um mesmo texto japonês é reveladora não apenas de seus peculiares traços estilísticos, mas também de como eles se relacionam com a tradição literária do cânone japonês (língua de partida) e do cânone

\footnotetext{
${ }^{3}$ Para Walter Benjamin, “o que lhe é essencial não é comunicável, não é enunciado” (BENJAMIN, 2011: 102), motivo pelo qual a tradução literal seria a "transmissão inexata de um conteúdo inessencial" (idem). Aquilo que realmente importa num poema, para o autor alemão, é "o inapreensível, o misterioso" (idem), cabendo ao tradutor a tarefa de encontrar, em seu próprio idioma, um eco "capaz de reproduzir (...) a ressonância de uma obra estrangeira" (idem, 112).

${ }^{4}$ As traduções de Casimiro de Brito e Herberto Helder são analisadas no terceiro capítulo deste trabalho.
} 
português (língua de chegada), numa ampla teia intertextual iniciada por Wenceslau de Moraes (1854-1929), que em sua pioneira jornada tradutória adaptou o haicai japonês na forma tradicional da quadra portuguesa, incorporando toda sorte de expressões coloquiais e trocadilhos. A tradução criativa, conforme Marcelo Tápia, percorre justamente a saga de "reinvenção de uma tradição, inserida em novo contexto" (idem, XVIII). A tradição não é um território imutável ${ }^{5}$, mas algo vivo, suscetível de metamorfoses. Conforme Haroldo de Campos, ela "não se move apenas pela homologação: seu motor, frequentemente, é a ruptura, a quebra, a descontinuidade, a dessacralização pela leitura ao revés" (CAMPOS, 1981: 208). Em vez da reconstrução da aura de um passado para sempre perdido, distante de nosso meio e cultura, a tradução criativa toma para si a responsabilidade pela "construção de uma tradição viva" como "um ato até certo ponto usurpatório, que se rege pelas necessidades do presente de criação" (idem, 39), escreve Haroldo de Campos. Nessa aventura linguística até certo ponto fabulatória, o texto 'transforma-se na 'viagem', e seu ponto de chegada acolhe-o de modo a participar de sua reestruturação, para a qual o presente, a releitura e a comunicação em novo espaço e em novo tempo são determinantes" (idem) Podemos pensar, aqui, no comentário de Marcelo Tápia a respeito do método tradutório de Augusto de Campos: "enfatizar a estrutura do texto e sua interação com o leitor permitirá um desapego da ideia de reconstruir um mundo passado (uma vez que este se modifica pelo mundo presente no ato da leitura e da recriação)", o que, na opinião do autor, caminha "ao encontro do conceito de make it new" (in CAMPOS, 2013: XIX). Refabular uma cultura, um texto literário de um idioma e concepção de mundo tão distantes do universo eurocêntrico, sem dúvida, é um risco, inclusive para o texto

\footnotetext{
5 A visão da tradição como espaço estático, "puro", é questionada também por Rudolf Borchardt, em seu livro A imagem histórica da Ilíada afirma: "toda tradição está destruída. Os motivos decisivos estão sempre perdidos, inclusive quando aparentemente foram transmitidos” (in MILÁN, 2002: 74).
} 
original: segundo Derrida, em seu livro Torres de Babel, "o original se dá modificandose, esse dom não é o de um objeto dado, ele vive e sobrevive em mutação" (DERRIDA, 2002: 38). O autor francês cita, em seguida, um adágio de Walter Benjamin: "Pois na sobrevida, que não mereceria esse nome se ela não fosse mutação e renovação do vivo, o original se modifica. Mesmo para as palavras modificadas existe ainda uma pósmaturação" (idem).

O texto poético refabulado em outra língua e ambiente cultural, dentro dessa concepção crítico-tradutória, seria a "desconstrução e reconstrução da história" porque "traduz a tradição, reinventando-a", na síntese feliz de Marcelo Tápia, proclive à concepção haroldiana (in CAMPOS, 2013: XVIII). Pensamento similar foi desenvolvido por Jorge Luis Borges no ensaio As versões homéricas, incluído no livro Discussão: "O conceito de texto definitivo não corresponde senão à religião ou ao cansaço" (BORGES, 1985: 71-72), de onde conclui: "pressupor que toda a recombinação de elementos é inferior ao seu original é supor que o rascunho $\mathrm{X}$ é obrigatoriamente inferior ao rascunho $\mathrm{Y}$ - já que não pode haver nada mais do que rascunhos" (idem). Sem rejeitar - por considerá-las inevitáveis - as omissões e ênfases que variam de uma versão para outra (no caso, traduções inglesas da Ilíada de Homero, e em especial as de Chapman, Buckley e Pope), Borges conclui: "Qual dessas numerosas versões é a fiel?, quererá saber talvez o meu leitor. Repito que nenhuma ou todas elas" (idem, 78). Para o autor do Livro de areia, "se a fidelidade tem que referir-se à imaginação de Homero, aos irrecuperáveis homens e dias que ele se representou, nenhuma delas pode ser fiel para nós” (idem). A hipótese da versão literal, centrada na

\footnotetext{
6 “Recuperar a história”, escreve Júlio Plaza, “é estabelecer uma relação operativa entre passado-presente e futuro, já que implica duas operações simultâneas e não-antagônicas: de um lado, a apropriação da história, de outro, uma adequação à própria historicidade do presente, estratégia esta que visa não só vencer a corrosão do tempo e fazê-lo reviver, mas também visa sublinhar que as coisas somente podem voltar como diferentes." (PLAZA, 2013: 5-6)
} 
pura referencialidade, é abandonada pelo autor da História universal da infâmia, que considera: "Em cada idioma, não acredito que haja sinônimos, nem sequer sei se a palavra lua é uma tradução exata da palavra inglesa moon. Possivelmente não, já que essa palavra passou por diferentes autores e cada um a escreveu diferente" (entrevista publicada na revista Gaia n. 1: 1989, 5). Citando o exemplo do pesadelo, Borges assinala a diferença de significados culturais entre o termo inglês nightmare, "que significa, no inglês antigo, 'demônio da noite", e o termo francês cauchemar, que "gerou a famosa metáfora do pesadelo, le cheval noir de la nuit" (idem, 8). A analogia borgiana é reforçada por Karlheinz Stierle, para quem "o caso ideal de um significante que tenha um e apenas um significado, conforme nos ensina qualquer dicionário, praticamente inexiste" (in LIMA: 2011, 123), uma vez que "cada significante evoca, de imediato, um horizonte de significados possíveis, dentro do qual se há de descobrir o significado visado" (idem). Dessa forma, "a significação frasal é uma hipótese, que se erige sobre uma quantidade de significados correlacionados, que, por sua vez, são projetados sobre a base material dos significantes" (idem). A atividade tradutória, em consequência, não se afasta de uma certa refabulação, ou "reimaginação" - termo usado por Haroldo de Campos para se referir às suas recriações de poesia chinesa e japonesa e o exemplo mais notório é talvez o de Edward FitzGerald, cidadão inglês do século XIX que traduziu o Rubayat de Omar Khayyam, autor persa do século XI (a palavra rubayat é o plural de rubai, quadra persa em que o primeiro, o segundo e o quarto verso rimam entre si. Essa forma breve pode ser comparada com o terceto japonês, ou haicai, com a quadra chinesa, ou jueju, e com o poema breve coreano, o sijô, esse último traduzido no Brasil por Yun Jung Im e Alberto Marsicano no livro Sijô - poesiacanto coreana clássica. São Paulo: Iluminuras, 1994. No Ocidente, o poema breve tem uma história que remonta ao epigrama, ao dístico e outras formas da poesia clássica grega e 
romana) O tema é abordado por Borges em outro ensaio, publicado no volume Outras inquisições:

Aconteceu um milagre: da fortuita conjunção de um astrônomo persa que condescendeu à poesia e de um inglês excêntrico que percorre, talvez, sem entendê-los por completo, livros orientais e hispânicos, surge um extraordinário poeta, que não se parece com nenhum dos dois. Swinburne escreve que FitzGerald "deu a Omar Khayyam um lugar perpétuo entre os maiores poetas da Inglaterra", e Chesterton, sensível ao que há de romântico e de clássico nesse livro sem par, observa que ao mesmo tempo há nele "uma melodia que escapa e uma inscrição que dura". Alguns críticos entendem que o Omar de FitzGerald é, de fato, um poema inglês com referências persas; FitzGerald interpolou, afinou e inventou, mas seus Rubayat parecem exigir que os leiamos como persas e antigos. (BORGES, 1999: 73)

FitzGerald, “amador” em cultura persa, segundo Haroldo de Campos, “não hesitou em situar-se, com desenvoltura, na polêmica dos 'orientalistas' a respeito da interpretação mística ou realista dos versos de amor e vinho do poeta-astrônomo dos Rubayat" (CAMPOS, 2013: 43), tomando o partido de uma interpretação laica e hedonista, em detrimento da leitura esotérica sufi, assim como fez Goethe, em seu Diva Ocidental-Oriental, na transposição criativa de versos de Hafiz (poeta também homenageado por Manuel Bandeira, na Lira dos cinquent'anos, na curiosa composição Gazal em louvor de Hafiz, que recria em português o verso monorrimo da tradição persa e árabe-andaluz). "Qualquer tradução é uma 'aventura histórica' e não definitiva, sobrevive em função das convenções culturais de sua época ${ }^{7}$, , resume Yao Feng.

A tradução poética, portanto, transcende a desejada identidade entre texto "original" e texto recriado, ao se materializar em um novo original, que responde às inquietações estéticas e históricas de um outro momento e cultura. A esse propósito, escreve João Alexandre Barbosa, em As ilusões da modernidade: "Traduzir significaria assim distanciar-se cada vez mais do sentido original pela modificação de um contexto básico perdido" (BARBOSA, 2005: 156). O que é possível preservar, sempre de forma parcial, nesse processo criativo, são alguns vestígios da informação estética (Max

\footnotetext{
${ }^{7}$ BONVICINO, Régis e FENG, Yao, 2007: 138.
} 
Bense), do original, sem presunção de verdade ou pureza. Conforme escreve Haroldo de Campos: "Teremos, como quer Bense, em outra língua, uma outra informação estética, autônoma, mas ambas estarão ligadas por uma relação de isomorfia: serão diferentes enquanto linguagem, mas, como os próprios corpos isomorfos, cristalizar-se-ão dentro de um mesmo sistema" (CAMPOS, 2013: 4). Em vez da busca inalcançável de reproduzir fielmente uma realidade em outra, tão distinta em formas históricas, estéticas e culturais, teríamos a possibilidade da interpretação. Para João Alexandre Barbosa, a tradução poética não é mais encarada como a "busca do Sentido - de que se nutriu e se nutre toda a hermenêutica religiosa desde, pelo menos, Friedrich Schleiermacher - mas como produção de sentidos" (idem). Esta operação é, evidentemente, crítica: "na medida em que a tradução é vista como produção de sentidos, envolvendo o processo de interpretação, a passagem de um código a outro, seja ele qual for, exige o exercício da crítica" (idem, 157), ao que podemos acrescentar: crítica do fazer poético do passado pela escolha de determinado autor, texto e conjunto de recursos formais utilizados - e crítica do fazer poético do presente, pela produção e circulação de um texto poético que reafirma ou questiona valores estéticos hegemônicos na criação poética e nos estudos literários da época corrente. Lembremos, a esse propósito, que o trabalho tradutório de Ezra Pound estava intimamente ligado ao seu pensamento crítico, em particular à noção de paideuma, ou "ordenação do conhecimento de modo que o próximo homem ou geração possa achar, o mais rapidamente possível, a parte viva dele e gastar um mínimo de tempo com itens obsoletos ${ }^{8}$. . Ao traduzir Jules Laforgue ou Tristan Corbière, por exemplo, havia a deliberada intenção de valorizar a linhagem "coloquial-irônica" do Simbolismo francês, numa época em que ainda predominava certa poesia confessionaldecadentista. Do mesmo modo, as criativas traduções que Pound realizou da poesia

\footnotetext{
${ }^{8}$ POUND, 1978: 11-12.
} 
chinesa (Li T'ai Po) e japonesa (Hagoromo), a partir dos estudos de Fenollosa, contribuíram para o surgimento do imagismo e da técnica de composição que o poeta norte-americano desenvolveu em seu poema longo Cantos (ou Cantares) - a montagem "ideogrâmica" de versos ou blocos de texto, obedecendo a um pensamento analógico. O estudo dos caracteres chineses influenciou também o método de estudo de poesia desenvolvido por Pound, baseado na comparação entre textos de diferentes autores e épocas (por isso mesmo, chamado método ideogrâmico), tendo em vista o objetivo da renovação estética (Make it new, frase adotada por Pound a partir de um adágio confuciano do século VI a.C.). Em depoimento sobre o processo de criação do dístico In a station of metro, datado de 1912, exemplo mais notório do "japonismo" em sua literatura (The apparition of these faces in the crowd: / Petals on a wet, black bough. "A visão destas faces dentre a turba: / Pétalas num ramo úmido, escuro, na tradução de Augusto de Campos, in POUND, 1983: 93), Pound refere-se ao princípio de justaposição do haicai japonês ("the hokku sentence"”), tema estudado pelo orientalista Ernest Fenollosa no ensaio Os caracteres da escrita chinesa como um instrumento para a poesia, que teve edição póstuma aos cuidados do próprio Pound.

A tese central de Fenollosa, mais atento à estética do que à gramática ou à filologia ${ }^{10}$, afirma: "Nesse processo de compor" (a escrita em caracteres ideográficos), “duas coisas que se somam não produzem uma terceira, mas sugerem uma relação fundamental entre ambas ${ }^{11 "}$ (in CAMPOS, 2000: 116). Como exemplo, cita o ideograma

\footnotetext{
${ }^{9}$ In CAMPOS, 2013: 28.

${ }^{10}$ Pound escreveu sobre o ensaio de Fenollosa: "O que temos aqui não é uma simples discussão filológica e sim um estudo dos fundamentos da estética (...). Fenollosa viu-se logo impelido para diversas modalidades de pensamento que desde então produziram frutos na 'nova' pintura e na poesia ocidental. Foi um precursor sem o saber, e sem que o reconhecessem como tal”. (in CAMPOS, 2000: 109)

11 O cineasta Sergei Eisenstein, de maneira análoga a Fenollosa, afirma: "A combinação de dois elementos suscetíveis de serem 'pintados' permite a representação de algo que não pode ser graficamente retratado" (in CAMPOS, 2000: 151).
} 
que representa comensal, formado pela justaposição dos signos homem e fogueira. O cineasta soviético Sierguéi Eisenstein (atento ao princípio da montagem na escrita chinesa e japonesa, que considera o cinema antes do cinema), fornece outros exemplos, no ensaio O principio cinematográfico e o ideograma (1929): "o desenho da água e o desenho de um olho significam 'chorar'; o desenho de uma orelha perto do desenho de uma porta = 'ouvir'. Mas, isto é... montagem! Sim, é exatamente isto que fazemos no cinema" (in CAMPOS, 2000: 151). A relação analógica está presente mesmo na construção de frases simples do cotidiano, segundo Fenollosa, que cita a sentença "O sol se ergue a leste", que em chinês se escreve com os seguintes caracteres:

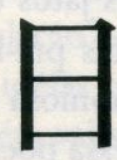

Sol

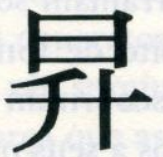

(se) ergue

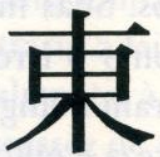

(a) leste

\section{Figura 1}

O signo que representa o sol se repete nos dois signos seguintes, num movimento cinético, e no último visualizamos uma síntese, "formado por um sol entrelaçado aos galhos de uma árvore ${ }^{12,}$, conforme o orientalista norte-americano, que após converterse ao budismo adotou o nome japonês de Kanō Yeitan Masanobu. Não será despiciendo recordar aqui a frase do cineasta francês Jean-Luc Godard: "Não existe imagem, não existe senão relação entre imagens ${ }^{13}$,, fórmula que pode ser aplicada tanto à montagem cinematográfica $^{14}$ (comparação realizada anteriormente por Eisenstein e colocada em

\footnotetext{
${ }^{12}$ In CAMPOS, 2000: 136.

${ }^{13}$ Suplemento Literário de Minas Gerais (Belo Horizonte, fev./2011).

${ }^{14}$ Mário Alves Coutinho, no artigo intitulado Godard: montagem: cinema: literatura: história escreve: "A montagem seria, segundo Jacques Aumont e Michel Marie, uma atividade que consistiria em 'colar uns após outros, em uma ordem determinada, fragmentos de filme, os planos, cujo comprimento foi igualmente determinado de antemão' (AUMONT/MARIE, 2003: 195-196). (...) De uma maneira geral, poderia ser dito que o cinema americano (o que se costuma chamar o 'cinema clássico hollywoodiano', uma construção em grande parte atribuída a Griffith, cuja linguagem ele estabeleceu e que perdura
} 
prática em filmes como Outubro, A greve e Encouraçado Potemkin) quanto ao processo de aglutinação de signos na escrita ideográfica. Em outro exemplo, referido por Haroldo de Campos, temos o ideograma que representa de modo metafórico o conceito de lealdade, formado pelos signos de coração + meio:

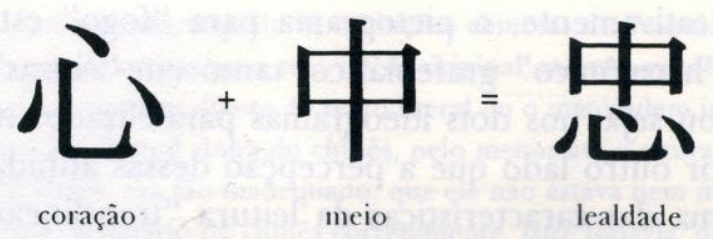

\section{Figura 2}

Temos aqui uma peculiar junção entre um signo icônico (coração) e um signo puramente fonético (meio) para a construção de um conceito abstrato (lealdade), que poderia ser traduzido, literalmente, como "ter o coração de alguém no centro", conforme interpretação de J. Y. Liu (idem, 57). Um último exemplo, ainda mais metafórico, é o verso de Li Shang-yin (813-858 d.C.), poeta da dinastia T’ang, considerado um dos mais obscuros da poesia clássica chinesa:

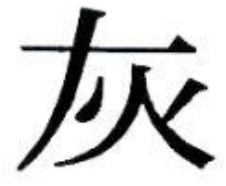

rinzas

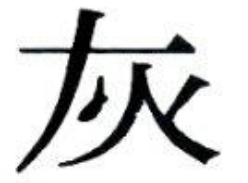

cinzas + coraçào $=$ desespero

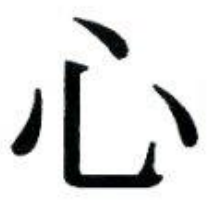

outono sobre coraçio = sentir-se melancólico, triste
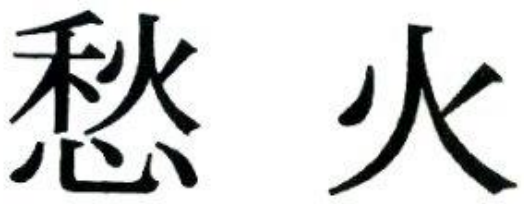

fogo

\section{Figura 3}

basicamente até hoje) valorizou principalmente a narratividade: como contar uma história (...). Eisenstein - que começou a fazer cinema influenciado por Griffith, mas muito cedo criou sua própria concepção de montagem - muda o eixo da discussão e da prática da montagem ao vê-la não mais como puramente narrativa, mas como conflito: 'então, montagem é conflito' (EISENSTEIN, 2002: 43), ele escreveria em Fora de quadro. Aqui, trata-se de 'efeitos figurais, a montagem podendo, por exemplo, estabelecer uma relação de metáfora' (AUMONT/MARIE, 2003: 196). Ou, nas palavras de Eisenstein, em A forma do filme, 'um cinema que procura um laconismo máximo para a representação visual de conceitos abstratos' (EISENSTEIN, 2002: 37). Ou, mais concretamente ainda, em $O$ sentido do filme, 'dois pedaços de filme de qualquer tipo, colocados juntos, inevitavelmente criam um novo conceito, uma nova qualidade, que surge da justaposição’ (EISENSTEIN: 2002, 14)" (idem). 
Conforme interpretação de J. Y. Liu, o poeta chinês associou uma palavra que remete a uma imagem concreta, cinzas, a outra de sentido abstrato, desespero, representada graficamente por "cinzas ao lado do coração" (idem, 37), flash metafórico que sugeriu a Haroldo de Campos uma leitura verlainiana: "outono sobre o coração" (a tradução integral deste poema pode ser lida no livro Escrito sobre jade, organizado e traduzido por Haroldo de Campos, e também na Antologia da poesia clássica chinesa - Dinastia T'ang, de Ricardo Portugal, que constam nas referências bibliográficas deste trabalho).

A contribuição original de Fenollosa para os estudos de poética, em síntese, reside na abordagem da escrita ideográfica como detentora de uma lógica pictórica e relacional, baseada na justaposição de signos, não raro de forma metafórica (quando ocorre "a utilização de imagens materiais para sugerir relações imateriais", idem, 127), que combina o som (tempo) e a imagem (espaço). O pensamento de Fenollosa, apesar de refutações recentes quanto ao suposto caráter imitativo-figurativo dos caracteres chineses $^{15}$, é defendido por autores como Jian-Zhang, Laszlo K. Géfin e Ed Brumby, que apontam a iconicidade inerente à escrita chinesa, mesmo nos signos estilizados que já não podem ser considerados como figuras abreviadas. Esta mesma iconicidade é percebida, inclusive, nos sinais puramente fonéticos, que têm uma dimensão plástica,

\footnotetext{
${ }^{15}$ Haroldo de Campos, no livro Ideograma: lógica, poesia, linguagem cita um estudo de I. Taniguchi, que classifica os ideogramas chineses em seis categorias. As duas primeiras, hsiang-hsing e chi-shih, "representam diretamente uma coisa ou uma imagem", constituindo "ideogramas de natureza pictorial, cuja significação independe da língua falada considerada (chinês, japonês ou coreano). (...) A terceira classe, huey-yi (...), constitui-se pela junção de dois ou mais elementos pictográficos ou indicativos, não perdendo o compósito resultante 'sua natureza ideogrâmica' ('sua significação resulta do significado dos diferentes elementos, Wieger). (...) Considera, então, o autor a quinta e a sexta classes, respectivamente chuang-chu (aplicação extensiva, por analogia, metáfora, adaptação, segundo Wieger) e chiah-chieh ('falso empréstimo', idem). Trata a quinta expressão da 'energia dinâmica' do caráter chinês, capaz de sofrer transformações no tempo; a sexta, vista como 'empréstimo por homofonia', parece-lhe um desenvolvimento da 'ideia latente' na quarta, vale dizer, hsieh-sheng. Nesta se detém, por ser a mais relevante, já que constitui $90 \%$ da escrita chinesa, sendo 'produto de uma duplicidade - o fonético $+o$ radical - e não mero fonograma'. (...) Assim - argumenta I. Taniguchi - 'a relação entre signifiant $\mathrm{e}$ signifié é motivada (isomorfismo: signo icônico) ou antes, o signifiant já é diretamente o signifié'. E conclui: 'Pode-se dizer que Fenollosa e Pound intuitivamente divisaram essa natureza semiótica do ideograma chinês'.” (Idem, 12-13)
} 
ressaltada na caligrafia artística (書道, shodô) ${ }^{\mathrm{i}}$. Segundo declaração de Ed Brumby, a “intenção real” de Fenollosa seria demonstrar "até que ponto a escrita poética chinesa e japonesa estavam estreitamente ligadas, num sentido visual, a outras formas expressivas, como a pintura" (idem, 17-18). A respeito do "elemento visual na poesia japonesa", Haroldo de Campos escreve que "é algo que lhe é intrínseco, que participa de sua própria natureza" (CAMPOS, 1977: 63). "Não se trata, apenas, da metáfora visual, daquilo que Pound denominava "fanopeia", observa o poeta brasileiro, "mas de alguma coisa ainda mais essencial, que radica na própria estrutura do kanji, o ideograma chinês que os japoneses importaram para sua escrita na segunda metade do século III de nossa era" (idem). O kanji, que surgiu como escrita pictográfica (desenho de objetos), evoluiu "para uma notação extremamente sintética e estilizada", prossegue, constituindo uma "verdadeira metáfora gráfica, tanto mais complexa quanto mais 'abstratas' as ideias a veicular", uma vez que nesse sistema de escrita é possível "representar não apenas coisas do mundo real, como também emoções, sentimentos etc. (daí a pertinência do termo ideograma, ou representação gráfica de ideias)" (idem, 63-64). A visualidade inata da lírica japonesa é realçada pela caligrafia, "que dá corpo ao poema, tendo ela em si, já na feição que os traços assumem, a capacidade de fixar estados de espírito", escreve Leonardo Fróes (in CAPPARELLI e YUQI, 2012: 23). "Poesia, caligrafia e pintura são a rigor faces da mesma arte, não estando as três compartimentadas, e às vezes um mesmo artista, caso de Wang Wei, se destaca como mestre em todas" (idem). A recuperação da visualidade da escrita é justamente a pedrade-toque do experimentalismo poético português, que irá pesquisar os labirintos visuais da poesia maneirista e barroca ${ }^{16}$ e o grafismo de antigos alfabetos do Ocidente e do Oriente, além de explorar as interfaces entre poesia, artes visuais e tecnologia. A saga

\footnotetext{
${ }^{16}$ Tema abordado por Ana Hatherly em A experiência do prodígio - bases teóricas e antologia de textos
} 
dos vanguardistas portugueses começou em 1962 com a publicação de Ideogramas, de Melo e Castro, série de 29 poemas visuais elaborados à maneira de Apollinaire - a disposição gráfico-visual mimetiza o referente, como nos Calligrammes. O poema pêndulo, por exemplo, é construído a partir de uma única palavra fragmentada, em que as partículas semânticas são diagramados de modo a sugerir o movimento pendular:

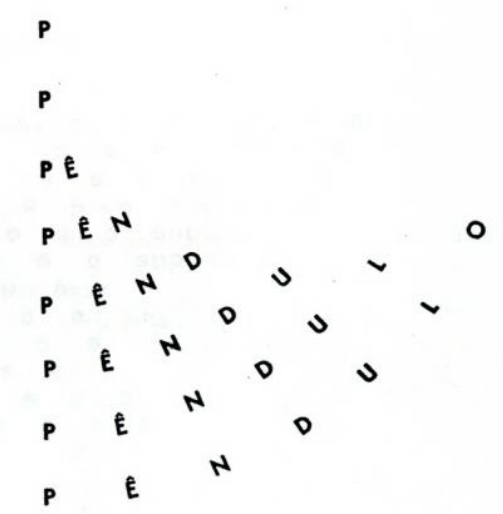

\section{Figura 4}

O espelhismo icônico entre signo e significado está presente não apenas no design da composição, mas na própria consoante inicial $p$, que comparece em todas as linhas, cujo formato recorda um pêndulo invertido. Nesse discurso visual não-linear, a sintaxe normativa é abolida: não há relação sujeito/verbo/objeto nem qualquer qualificação do referente, numa representação plástica da ideia. Esta série de poemas — primeiro registro do experimentalismo poético em Portugal —, apesar de sua radicalidade inventiva, tem poucas afinidades com a lógica (e a estética) do ideograma: a concisão e a visualidade estão presentes, bem como a "compreensão sintático-ideográfica", em lugar do discurso "analítico-discursivo", mas dois elementos essenciais da escrita ideográfica estão ausentes: a técnica de montagem ou justaposição de signos e a gestualidade caligráfica. Na segunda série de Ideogramas, nos poemas visuais 
intitulados Cinéticos (ambos de 1966) e sobretudo em seus infopoemas, desenvolvidos com recursos de informática, Melo e Castro superou a fase mimético-referencial, incorporando o "borrão", a "mancha", que criam atrito com as camadas de significados e atribuem à escrita um caráter plástico mais expressivo, símile à caligrafia artística japonesa. Diálogo mais explícito com as artes japonesas pode ser rastreado no trabalho pictórico de Ana Hatherly, sobretudo na notável série de desenhos caligráficos intitulada Mapas da imaginação e da memória (1973) e em Hand made (2000), conjunto de desenhos e pinturas expostos inicialmente em 1992, no Centro de Arte Moderna da Fundação Calouste Gulbenkian. A autora portuguesa, que se interessou pelo Budismo Zen na década de 1960, estudou diferentes alfabetos antigos, como o chinês, o árabe, o grego, o rúnico, para inventar um repertório de sinais que ela denominou de "alfabeto estrutural" ou "alfabeto conceptual", composto de oito signos, que combinados entre si permitem 64 variações, como no I ching:

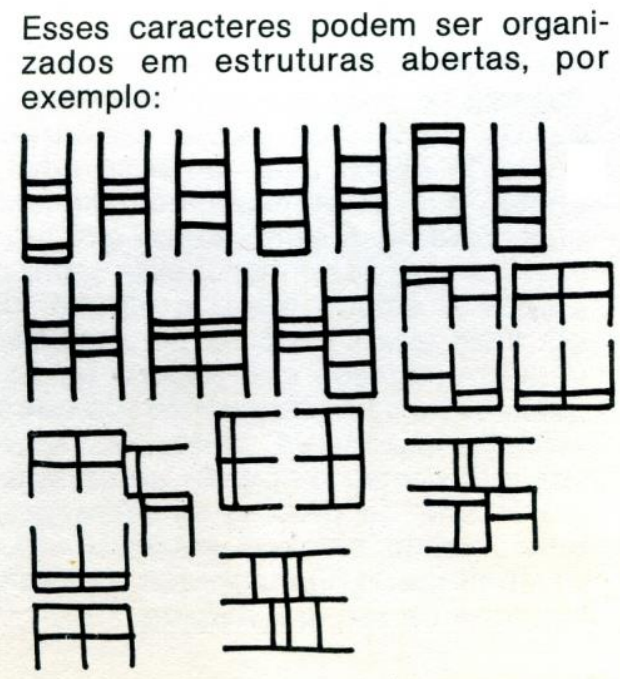

\section{Figura 5}

Neste alfabeto de ruídos abstratos, em que o referente está ausente, é a caligrafia, o borrão, enfim, o gesto pictórico que compõe os textos visuais, à maneira do shodô. 
Ana Hatherly também se encantou com os "desconcertantes textos usados pelos Mestres Japoneses para instruir os seus discípulos" (HATHERLY, 2006: 12-13), conhecidos como koans. A leitura de tais textos causou na autora "profunda impressão e, em termos estruturais, deixara, a sua marca na minha concepção das Tisanas" (idem, 13). Como exemplo ilustrativo da "reimaginação" do koan pela autora portuguesa, citamos abaixo uma fábula relatada por Taisen Deshimaru, no livro A tigela e o bastão, e a Tisana 12:

\section{A CABEÇA E O RABO}

Havia uma serpente cuja cabeça e cujo rabo viviam brigando. O rabo dizia:

-- Fico sempre para trás, enquanto tu vais na frente, e sou obrigado a seguir-te.

No fim de contas, o rabo enrolou-se numa árvore. Não queria mais avançar. A cabeça viu uma bonita rã. Quis comê-la, mas não pode.

Diante disso, a cabeça permitiu ao rabo que fosse na frente. Mas, como o rabo não tinha olhos, caiu num buraco e a cabeça morreu na queda.

(DESHIMARU, 1983: 33)

\section{TISANA 12}

Era uma vez duas serpentes que não gostavam uma da outra. Um dia, encontraram-se num caminho muito estreito e como não gostavam uma da outra devoraram-se mutuamente. Quando cada uma devorou a outra não ficou nada. Esta história tradicional demonstra que se deve amar o próximo ou então ter muito cuidado com o que se comer (sic).

(HATHERLY, 2006a: 23)

A estrutura narrativa do koan, em que o humor e o absurdo intencional são usados para abalar o raciocínio lógico, permitindo uma compreensão intuitiva dos eventos, tem uma relação especular com as Tisanas, obra em progresso formada por pequenos poemas em prosa, aforismáticos, que a poeta portuguesa vem publicando desde 1967, e também os inventos em prosa de Herberto Helder, como a Teoria das cores, publicada inicialmente 
nos Cadernos de poesia experimental e posteriormente incluída no volume Os passos em volta (1963):

\section{TEORIA DAS CORES}

Era uma vez um pintor que tinha um aquário e, dentro do aquário, um peixe encarnado. Vivia o peixe tranqüilamente acompanhado pela sua cor encarnada, quando a certa altura começou a tornar-se negro a partir - digamos - de dentro. Era um nó negro por detrás da cor vermelha e que, insidioso, se desenvolvia para fora, alastrando-se e tomando conta de todo o peixe. Por fora do aquário, o pintor assistia surpreendido à chegada do novo peixe.

O problema do artista era este: obrigado a interromper o quadro que pintava e onde estava a aparecer o vermelho do seu peixe, não sabia agora o que fazer da cor preta que o peixe lhe ensinava. Assim, os elementos do problema constituíam-se na própria observação dos fatos e punham-se por uma ordem, a saber:

1) peixe, cor vermelha, pintor, em que a cor vermelha era o nexo estabelecido entre o peixe e o quadro, através do pintor;

2) peixe, cor preta, pintor, em que a cor preta formava a insídia do real e abria um abismo na primitiva fidelidade do pintor.

Ao meditar acerca das razões por que o peixe mudara de cor precisamente na hora em que o pintor assentava na sua fidelidade, ele pensou que, lá dentro do aquário, o peixe, realizando o seu número de prestidigitação, pretendia fazer notar que existia apenas uma lei que abrange tanto o mundo das coisas como o da imaginação. Essa lei seria a metamorfose. Compreendida a nova espécie de fidelidade, o artista pintou na sua tela um peixe amarelo.

(HELDER, 2004: 21)

A antifábula helderiana desarticula o tecido lógico cartesiano e apresenta uma outra lógica, baseada na observação da impermanência dos fenômenos, que o autor denomina "lei da metamorfose": o peixe vermelho torna-se negro e por fim amarelo, numa alegoria da ideia budista da contínua mutação de todas as coisas, afim do devir heraclítico. As técnicas de repetição, combinação e permutação das células semânticas, recorrentes na poesia barroca, são usadas por Helder nesta e em outras composições, como a Comunicação acadêmica, também de 1963. Neste insólito poema em prosa, Helder esvazia o sentido habitual das palavras, para transformá-las em termos quase abstratos, com evidente caráter lúdico. Podemos recordar, a esse propósito, uma sentença de Roland Barthes a respeito do haicai, no livro $O$ império dos signos: "O que 
é abolido não é o sentido, é toda idéia de finalidade" (BARTHES, 2007: 111). Operando como um agente sabotador na linguagem, o haicai teria a capacidade de "esvaziar, estupefazer, enxugar a tagarelice" (idem, 98), observa o semioticista francês, e o clímax dessa experiência seria o estado de satori (悟り, “compreensão”, “iluminação", conceito que será discutido na página 202 deste trabalho), ou "suspensão pânica da linguagem" (idem). A radicalidade inventiva do texto helderiano, imbuído de uma vontade de dissolução luciferina, avizinha-se portanto da estratégia criativa adotada por Ana Hatherly em suas Tisanas, dotadas de uma "indeterminação deslizante", de uma “técnica de destruição da certeza" (HATHERLY, 2006: 13). A autora portuguesa, comentando essa série de pequenos poemas em prosa, símile de um diário de espantos, escreve: “As Tisanas também são uma reflexão sobre a ilusão da verdade que é a arte, uma reflexão sobre a cultura como projeção da invenção do real, uma reflexão sobre o jogo como veículo de conhecimento na sua função libertadora de energia, criadora de liberdade e de reflexão sobre as formas" (idem), comentário que podemos estender à escritura criativa helderiana enquanto elaboração crítica dos discursos culturais e intervenção de uma utopia estética. Roland Barthes comenta que o Zen busca "deter a linguagem" (BARTHES, 2007: 98), visando um estado de silêncio interior, de cessação do pensamento, o que na poesia pode corresponder à concisão, à elipse, a uma ação “sobre a própria raiz do sentido, para fazer com que esse sentido não se difunda, não se interiorize (...), não divague no infinito das metáforas, nas esferas do símbolo" (idem). O haicai, conforme o semioticista francês, "não é um pensamento rico reduzido a uma forma breve, mas um acontecimento breve que acha, de golpe, sua forma justa" (idem). Estas definições podem ser aplicadas, com distanciamento crítico, a dois poetas portugueses de escrita lacunar, aforismática: Albano Martins e Eugênio de Andrade. 
Albano Martins, que publicou seu título de estreia, Secura verde, em 1950, deixou-se contaminar, inicialmente, pelo influxo da poesia grega e latina, traduzindo poemas breves de Alceu e Safo. Sua afinidade pela concisão semântica - representada, no cânone ocidental, por formas poéticas breves como o dístico, o epigrama e a quadra - orientou boa parte de suas criações textuais, como este terceto, publicado no livro Coração de bússola (1967): "A vida / -- essa invenção magnífica / da morte” (MARTINS, 2000: 44). No livro Em tempo de memória (1974), o autor português praticou uma escrita ainda mais concentrada, dispondo palavras e frases na página como se intentasse a representação visual do movimento rítmico. O poema Modulação, por exemplo, é construído como uma sequência de breves aforismos, sem relação de continuidade referencial ou sintática entre as estrofes (ou fragmentos):

3.

De inomináveis obscuros, refluentes sinais se tece a polpa, a medula do espaço que habitamos.

$*$

O ritmo do universo cabe, inteiro, na pupila dum verso.

Árvores que me doem na garganta Quem as arranca? Quem as planta?

*

Branco, 
solúvel

veneno

ao rés

das pálpebras

arde

lento.

$*$

De lágrimas se molha

o tempo e a memória.

(MARTINS, 2000: 69-70).

Podemos pensar numa analogia com o princípio da justaposição de imagens na poesia japonesa, reforçada por outros elementos da estética do autor, como os cortes elípticos, o discurso paratático e a distribuição das linhas, simulando formas geométricas de uma caligrafia tipográfica (com ecos evidentes da Micropaisagem de Carlos de Oliveira). Os paradoxais jogos de pensamento do poema, por sua vez, recordam a escrita enigmática dos koans, especialmente na estrofe: "O ritmo / do universo / cabe, / inteiro, / na pupila / dum verso", com os deliberados contrastes entre maior e menor, o que está em cima e o que está em baixo. A similaridade formal entre a escritura poética de Albano Martins e os textos japoneses, porém, não é fruto de uma recepção criativa direta: o próprio autor declarou que leu tardiamente traduções de Bashô, Issa e Buson. A coincidência fortuita é obra do ocaso objetivo ou de uma feliz sincronia, e se tornará diálogo consciente em obras mais recentes, como o volume Com as flores do salgueiro (1993), homenagem ao tricentenário da morte de Bashô. O livro é formado por 48 poemas escritos na forma do terceto, sem métrica ou rimas e com a presença do signo da estação do ano (kigo). Ao lado de cada poema, escrito em português, Albano Martins incluiu a tradução para o japonês, com os kanjis dispostos em uma coluna vertical, e a versão para o inglês, numa convergência de idiomas. Como exemplo dessa delicada poética, citaremos um único poema: "Castanha é a cor / do sorriso / do ouriço" (MARTINS, 1995: 23). Para além do 
mero esqueleto frásico, Albano Martins, no dizer de José Fernando Castro Branco, buscou "o instante poético, a anotação rápida de um momento privilegiado, a fixação do efêmero pela palavra justa em que, como afirma Paz, 'o instante é incomensurável'” (BRANCO, 2004: 51).

Eugênio de Andrade - assim como Albano Martins - cultivou a forma breve já em seus primeiros livros publicados, antes de travar conhecimento com a poesia japonesa. Numa composição dos anos 1940, por exemplo, o autor diz: “o outono é isto / apodrecer de um fruto / entre folhas esquecido / Água escorrendo, / quem sabe donde, / ocasional e fria / e sem sentido" (ANDRADE, 2000: 14). Neste poema de apenas sete linhas, podemos vislumbrar uma série de paralelos com a poética do "Senhor Bananeira" Matsuo Bashô: a presença da referência sazonal, a montagem cinematográfica, o verbo indicando uma ação presente, o mistério sutil, a indeterminação. O poema, anterior em duas décadas à divulgação do haicai em Portugal por Herberto Helder e Casimiro de Brito, faz-nos pensar, novamente, numa situação de sincronia. Conforme Jakobson: "A descrição sincrônica considera não apenas a produção literária de um período dado, mas também aquela parte da tradição literária que, para o período em questão, permaneceu viva ou foi vivificada" (JAKOBSON, 1969: 121). Para o linguista soviético, "a escolha de clássicos e sua reinterpretação à luz de uma nova tendência é um dos problemas essenciais dos estudos sincrônicos" (idem). Júlio Plaza considera que há "duas formas de transmissão da história: a forma sincrônica e a diacrônica. Esta mais próxima do historicismo, aquela mais adequada e conatural ao projeto poético-artístico" (PLAZA, 2013: 2-3). Segundo o autor de A tradução intersemiótica, "a 'história inacabada' é a história morta, aquela que nada mais diz. A História, então, pressupõe a leitura. É pela leitura que damos sentido e reanimamos o passado". Nesse sentido, prossegue o autor, “a tradução (...) se apresenta como a forma mais atenta de ler a história porque é uma 
forma produtiva de consumo, ao mesmo tempo que relança para o futuro aqueles aspectos da história que realmente foram lidos e incorporados ao presente" (idem). Mais adiante, o autor afirma:

Estamos, pois, diante de duas chances: ou o presente recupera o passado como fetiche, como novidade, como conservadorismo, como nostalgia, ou ele o recupera de forma crítica, tomando aqueles elementos de utopia e sensibilidade que estão inscritos no passado e que podem ser liberados como estilhaços ou fragmentos para fazer face a um projeto transformativo do presente, a iluminar o presente (idem, 7).

A partir dessas reflexões teóricas, surge a inevitável pergunta: como podemos cotejar um autor japonês do século XVII, com seu lastro de cultura confucionista e zen-budista, com um poeta português do século XX que sonha com a Grécia clássica? Segundo Jakobson, é possível fazermos aproximações textuais de autores de diferentes períodos históricos e repertórios culturais que o olhar do "presente de criação" reconhece como símiles, embora sem comércio direto de ideias e formas entre eles. Dialogando com o pensamento do autor soviético, Haroldo de Campos afirma: “a literatura é o domínio do simultâneo, um simultâneo que se reconfigura a cada nova intervenção criadora" (CAMPOS, 1976: 21). Sob este paradigma, "cada época nos dá o seu 'quadro sincrônico', graças ao qual podemos ler todo o espaço literário - um espaço literário onde Homero é contemporâneo de Pound e Joyce" (idem). Concluindo, escreve o autor brasileiro: “Entre o 'presente de criação' e o 'presente de cultura' há uma correlação dialética: se o primeiro é alimentado pelo segundo, o segundo é redimensionado pelo primeiro" (idem, 22). O demônio da simultaneidade, com a sua lógica de conexões que transcendem fronteiras espaço-temporais, autoriza, portanto, a analogia ${ }^{17}$. A poesia de Eugênio de Andrade é um vasto palimpsesto onde notamos relações intertextuais diretas com os clássicos gregos e romanos, o panteísmo, o estoicismo, os espanhois da geração

\footnotetext{
17 O ensaio Uma arquitextura do barroco, publicado no livro A operação do texto, de Haroldo de Campos, inclui uma miniantologia sincrônica com poemas de autores tão distanciados no espaço-tempo como Góngora, Mallarmé, Sousândrade, Lezama Lima e Li Shang Yin.
} 
de 27 e só posteriormente, quando o autor já tinha consolidado a sua poética, com o haicai e o Budismo Zen. Quando descobre a poesia de Bashô, seu ignorado $\operatorname{antepassado}^{18}$, reconhece afinidades eletivas e presta homenagem ao poeta-samurai na conhecida peça Rumores de verão:
As cigarras cantam
como no inverno
arde lenha verde.
Um rumor pueril
e doce de abelhas
acrescenta a sede.
Quando o sol avista
os flancos do mar
despe-se a correr,
e dança dança dança.

(ANDRADE, 2000: 545)

Esta notável peça é construída na forma de três tercetos, com certa autonomia referencial e sintática. Podemos ler a composição como um pequeno conjunto de haicais, ou ainda como a montagem de três "planos", à maneira da técnica cinematográfica - que tanta afinidade possui com a escrita ideográfica. O primeiro terceto apresenta uma imagem simples e direta, com referência sazonal e uma ação que acontece no momento presente, comparada a outra ação que talvez (pelo grau de sutileza e ambiguidade do verso) aconteça no passado. O segundo terceto, mais intelectualizado, guarda pouca similaridade com a escrita espontânea do haicai japonês: a palavra rumor é adjetivada como pueril e a terceira linha introduz uma inusitada metáfora, figura pouco frequente na arte concentrada de Bashô e seus discípulos. O terceiro e último terceto apresenta uma curiosa prosopopeia, em que o sol se despe e corre para os

\footnotetext{
18 Jorge Luís Borges, no ensaio Kafka e seus precursores, incluído no volume Outras inquisições, escreve: "O fato é que cada escritor cria seus precursores. Seu trabalho modifica nossa concepção do passado, como há de modificar o futuro. Nesta correlação, não importa a identidade ou a pluralidade dos homens". (BORGES, 1999: 98).
} 
flancos do mar (imagem que recorda a desmesura de uma composição de Bashô: "o dia em chamas / joga no mar / o rio mogâmi”, na tradução de Paulo Leminski ${ }^{19}$, e também os conhecidos versos de Rimbaud: “Elle est retrouvée. / Quoi? — L' Éternité. / C'est la mar allée / Avec le soleil ${ }^{20 "}$, aproximação textual reforçada pela última linha do poema - "dança dança dança", citação de um poema em prosa do livro Une saison en enfer ${ }^{21}$ (traduzido no Brasil por Ledo Ivo). A intertextualidade, aliás, é um recurso verificável também na poesia de Bashô, como por exemplo no poema "Baía Kisa / Seishi dorme na chuva, / mimosas úmidas ${ }^{22}$, , que faz referência ao poeta chinês Su Tung-Po (10361101), que, nas palavras de Octavio Paz, “comparava a paisagem do lago Si Hu com a beleza de uma mulher da época, Hsi-Tzé (Seishi). Bashô, ao contemplar a baía de Kisagata, imagina a paisagem do lago Si Hu e recorda o poema chinês e Seishi",23.

Rumores de verão integra o volume Pequeno formato (1997), composto de 30 poemas - dísticos, tercetos, quadras. De todos os livros de Eugênio de Andrade, este é o que apresenta maior contenção verbal e vínculo direto com o imaginário e a escrita poética de Dai Nippon, como verificamos nesta outra composição, intitulada Jardim de Lou Lim Leouc: "Deste jardim o que levo comigo / é um ramo de bambu para servir / de espelho ao resto de meus dias" (idem, 551). A justaposição de cenas e ações simultâneas, princípio estrutural do tanka e do haicai, está presente em diversas peças do volume, especialmente no poema intitulado Verão: "Era verão, pela varanda entrava / a madura ondulação do trigo, / o grito lancinante dos pavões, / o cavalo na sombra ardendo em cio" (idem, 547), em que notamos ainda a referência sazonal e a unidade

\footnotetext{
${ }^{19}$ LEMINSKI: 1983, 51.

${ }^{20}$ RIMBAUD: 1984, 108.

${ }^{21}$ RIMBAUD: 1982, 52.

${ }^{22}$ BASHÔ: 1983, 84.

${ }^{23}$ Idem, 106.
} 
entre os acontecimentos da natureza, numa ordenação cósmica. O encontro de Albano Martins e Eugênio de Andrade com a poesia japonesa - assim como aconteceu com Herberto Helder, Ana Hatherly, Casimiro de Brito, Yvette Centeno, Melo e Castro - foi possível graças à tradução de poemas japoneses para o inglês, o francês e o espanhol (especialmente as versões para o inglês de R. H. Blyth, reunidas na obra em quatro volumes intitulada Haiku) e também pela divulgação no Ocidente de obras sobre o Zen, a pintura e a caligrafia japonesas, além dos relatos de viajantes como Fernão Mendes Pinto, Wenceslau de Moraes e Armando Martins Janeira. A leitura que os poetas portugueses fizeram da poesia japonesa, portanto, não partiu dos textos originais, mas de interpretações, e também dos estudos teóricos de autores como Fenollosa, Pound e Octavio Paz. Houve, assim, um intercâmbio estético e intelectual mediado pelas reflexões de escritores ocidentais sobre o haicai e a cultura japonesa, por um lado (com toda a carga inevitável de distorção e ruído) e da apreensão sensorial, silenciosa, das artes visuais japonesas, por outro. A pintura tradicional japonesa (sumiê), a caligrafia artística (shodô), os arranjos florais (ikebana), as gravuras coloridas (ukyo-ê), não precisam ser traduzidas: assim como a música, são linguagens artísticas apreensíveis pelos sentidos. Esta foi a "educação sentimental" dos poetas portugueses que na segunda metade do século XX se encantaram pelo Japão, convertido em território imaginado ou espaço semiótico regido não pela semântica ou pela gramática, mas pela sensibilidade e pela percepção das formas. Se a tradução poética projeta o lastro de cultura do presente no texto recriado, que se converte em novo original, processo similar acontece na criação poética que se deixa contaminar por temas e estilemas de um repertório tão afastado do nosso como é a lírica do Período Tokugawa. O exemplo mais notório dessa alquimia é o poeta-tradutor Casimiro de Brito, que participou de um dos movimentos de renovação da literatura portuguesa na década de 1960, o Poesia 61, 
e se tornou o principal responsável pela divulgação do haicai japonês em Portugal. Seu ambicioso projeto denominado LIVRO DOS HAIKU, iniciado em 1958, será composto por um total de 14 obras, sendo que duas já foram publicadas, até a presente data: $A$ sombra de Bashô, sequência de 110 composições que dialogam com poemas do autor japonês, na forma de imaginária renga, e Através do ar, editado no Japão, em quatro línguas, em parceria com Ban’Ya. Além desses títulos, Casimiro de Brito publicou as antologias Poemas orientais (1962) e Poesia japonesa (1995), com traduções realizadas conjuntamente com Ban'Ya ${ }^{24}$, preparou um dossiê sobre o haicai para a revista brasileira Poesia sempre e reuniu haicais de autores portugueses e brasileiros no livro Uma rã que salta - homenagem a Bashô (1995). Os haicais do próprio Casimiro de Brito, publicados no volume A boca na noite (2012), raramente têm medidas métricas fixas ou rimas; o autor prescinde da referência à estação do ano e investe na concisão formal e nos cortes elípticos. O diálogo com a poesia tradicional japonesa acontece em diversas composições, como por exemplo nesta peça: "Vagueiam pela casa / o homem, a mosca e o ar -- / ninguém descansa ${ }^{25,}$, que recorda um conhecido poema de Bashô traduzido por Kimi Takenaka e Alberto Marsicano: “em profundo silêncio / o menino, a cotovia / o branco crisântemo ${ }^{26 "}$ (BASHÔ, 1997: 10). Em ambos poemas, os temas centrais são a interdependência e a compaixão budista por todos os seres vivos, incluindo moscas, cotovias e crisântemos. As peças de maior originalidade, no entanto, são as situadas no final do volume, sob o título $C f$. Lautréamont, como esta curiosa composição, releitura intertextual focada na imagética surrealizante: “A terra não passa /

\footnotetext{
${ }^{24}$ Ban'Ya realiza a tradução literal dos haicais do japonês para o francês (idioma que leciona na Universidade de Tóquio) e Casimiro de Brito faz a versão final, do francês para o português, conforme depoimento prestado a mim pelo próprio poeta, via correio eletrônico. A parceria é mantida também na tradução dos poemas do próprio Ban'Ya para o português, com a colaboração de Casimiro de Brito.

${ }^{25}$ BRITO, 2012: 14.

${ }^{26}$ BASHÔ, 1997: 10.
} 
de um imenso cu celeste / fremindo, cantando". Claro - este não é um haicai, stricto sensu - temos aqui um terceto que estabelece uma conversa entre dois repertórios não apenas distintos mas, aparentemente, antagônicos: a poesia tradicional japonesa, de um lado, com toda a sua ética e etiqueta derivadas das normas de conduta confucionistas e da metafísica budista, e, de outro lado, a irreverência dos Cantos de Maldoror e de William Burroughs (autor de $O$ homem que ensinou o seu cu a falar). Em outro poema, Casimiro de Brito escreve: "Mãos vegetais / raízes de árvores invisíveis / trepando nas veias". Nesta peça, ainda mais estranha, as aliterações em $v$ e $s$ podem ser comparadas aos trocadilhos e jogos verbais da poesia japonesa, como o kakekotoba $(\text { 掛詞 })^{27}$; porém, a fúria semântica e metafórica está mais próxima do simbolismo e do surrealismo, movimentos aos quais Lautréamont, em geral, é associado. Nestas composições, que não ocultam o lastro de cultura ocidental (incluindo referências à filosofia pré-socrática grega, especialmente Tales de Mileto e Heráclito de Éfeso), Casimiro de Brito evita os clichês do japonismo, as repetidas imagens de cerejeiras, montanhas e neblinas para manifestar o seu próprio imaginário: citações ocidentais e orientais, do passado e do presente, eruditas e vulgares, biográficas e ficcionais, entrecruzam-se, entrespelham-se, entredevoram-se.

Yvette Centeno - assim como Casimiro de Brito - evita paisagens adocicadas e o registro caricatural de aspectos exteriores da cultura japonesa, adotando uma estratégia criativa voltada ao diálogo amoroso (por vezes conflituoso) entre diferentes repertórios culturais e idiomas. Na antologia Uma rã que salta, a autora portuguesa publicou uma

\footnotetext{
27 A montagem, inerente ao princípio da escrita ideográfica, também comparece, no plano semântico, num recurso peculiar da poesia japonesa chamado kakekotoba, ou "palavra pendurada", que Haroldo de Campos define como "um recurso de compressão semântica e ambiguidade poética, algo como a 'palavra-valise' de Lewis Carrol e Joyce. Assim, matsubara significa 'pinheiral' (matsu, pinheiro; bara, campo), mas, ao mesmo tempo, matsu é um verbo, com a acepção de esperar". (CAMPOS, 1993: 20) E Donald Keene, citado por Leminski em Matsuo Bashô, A lágrima do peixe, faz o seguinte comentário: "A palavra shiranámi, que significa 'ondas brancas', poderia sugerir a um japonês a palavra shiráni, que quer dizer 'desconhecido', ou 'námida', que quer dizer 'lágrima”' (in LEMINSKI, 1983: 39).
} 
renga realizada em parceria com Stephen Reckert (1923-2013), composta de 12 poemas - ela escreveu os tercetos (hokku), em português, e Reckert os dísticos (waki), em espanhol, italiano, inglês, francês e português, numa babel deliberada de línguas e camadas intertextuais. Os poemas, escritos sem medidas métricas ou referência sazonal, contrastam com a (aparente) simplicidade do haicai japonês, pela ostensiva (voluntária) presença do olhar intelectual, que não se limita a observar e registrar os fenômenos da natureza: assim, por exemplo, numa composição de claras referências intertextuais, que incorpora um ícone cultural do Ocidente ao cenário do poema japonês mais conhecido:

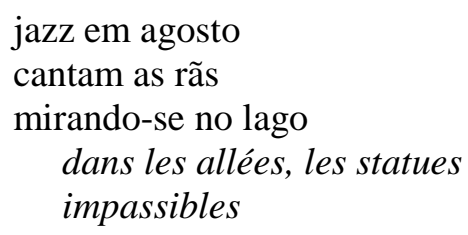

Yvette Centeno incorpora a música ao poema com ironia, mesclando o ritmo de Charlie Parker e John Coltrane ao coaxar das rãs, elevado ao nível do canto. Há também um contraponto entre a ação do poema e a impassibilidade das estátuas, nos versos escritos em francês, e a relação de espelhismo entre quem vê e quem é visto, numa possível referência ao leitor e ao ato da leitura. Em apenas cinco linhas (a medida de um tanka), há todo um hipertexto que desafia a simulação da ingenuidade e da pureza - qualidades de um ambiente rural e religioso talvez irreproduzível no espaço urbano conflituoso em que vivemos. No livro A Oriente, publicado em 1998, Yvette Centeno reúne nada menos que 80 haicais, numerados e sem títulos, mesclados a outros poemas breves, escritos em português e em francês. Nestas pequenas aquarelas poéticas, a autora faz alusões à mitologia grega ("Três mulheres, / três parcas: / uma delas cortará o fio",28), ao

\footnotetext{
${ }^{28}$ Idem, 45.
} 
Mahabharata (e "O elefante de bronze, / em vez do cavalo / alado ${ }^{29 "}$ - curiosa aproximação entre o deus-elefante Ganesha e o Pégaso helênico), à pintura hiperrealista

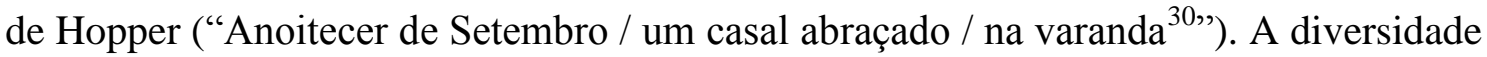
temática de Yvette Centeno, que navega entre multíplices códigos culturais, de diferentes territórios espaço-temporais, sintetiza, a nosso ver, a maneira como aconteceu a recepção criativa da poesia japonesa em Portugal - e usamos a palavra recepção, aqui, tal como compreendida por Haroldo de Campos, uma ação em que o receptor "não é alguém que recebe algo, nem está somente em estado passivo: em termos ótimos, ele deveria ser um coautor da informação" (CAMPOS, 2002: 83). Exercendo o papel de interpretante e "instigado pela criatividade do produtor (caso se tratasse de um produtor criativo)", caberia ao poeta dar "uma resposta criativa à mensagem", fazer a "crítica dessa mensagem" (idem). Retornamos, aqui, aos conceitos apresentados no início do presente texto, como os de refabulação, reimaginação, e também ao exemplo (alegórico) citado por Borges - o de Omar Khayyam traduzido por FitzGerald: não é a "fidelidade" semântica, a cópia ingênua do "conteúdo" de um presumível original (tido como puro e imutável) que faz a diferença criativa, a intervenção cultural no sentido mais amplo, e sim a reinvenção da tradição, com todas as possibilidades de ruído, dissonância, mescla, bizarria e deformação: movimento de caráter plagiotrópico ${ }^{31}$ (do gr. plágios, oblíquo; que não é em linha reta; transversal; de lado), distinto do esforço erudito de codificação

\footnotetext{
${ }^{29}$ Idem, 53.

${ }^{30}$ Idem, 49.

31 “A plagiotropia (...) se resolve em tradução da tradição, num sentido não necessariamente retilíneo. Encerra uma tentativa de descrição semiótica do processo literário como produto do revezamento contínuo de interpretantes, de uma 'semiose ilimitada' ou 'infinita' (Peirce, Eco), que se desenrola no espaço cultural. Tem a ver, obviamente, com a ideia de paródia como 'canto paralelo', generalizando-a para designar o movimento não-linear de transformação dos textos ao longo da história, por derivação nem sempre imediata. Conjuga-se com minha concepção da operação tradutora como o capítulo por excelência de toda possível teoria literária (e toda literatura comparada nela fundada)" (CAMPOS, 1981: 75-6, nota 5).
} 
de uma interpretação histórica, sociológica ou mesmo estética que se pretende "exata" ou "neutra". A criação poética, em suas relações com outros códigos culturais, nunca é "neutra" - ela assume a voluntária parcialidade de sua leitura crítica da tradição, reinventada para o tempo presente, os homens presentes. A visada sincrônica, por outro lado, não exclui ou elimina a diacronia e em nossa discussão dos poetas portugueses adotamos os dois paradigmas para recontarmos a trajetória do diálogo literário entre o Japão e Portugal. Entendemos a palavra recepção também no sentido que é dado a ela por Luiz Costa Lima, para quem “a imaginação é produtiva” (LIMA, 2011: 17). Segundo o crítico brasileiro, estudioso de Iser e Jauss, "o receptor não capta um reflexo, mas estabelece uma configuração, isto é, organiza, filtra e seleciona o que recebe" (idem). Em vez de considerar apenas a obra de arte enquanto materialidade formal, numa relação de dicotomia entre sujeito e objeto, a Teoria da Recepção considera a interação com o leitor-interpretante, exercendo "papel vivo e ativo" na "própria estrutura da obra" (idem). "O texto literário e artístico, tem, pois, como primeiro efeito converter o habitualizado em estranho" (idem, 24), escreve o autor brasileiro. Afirmar que "o significado do texto literário é engendrado no processo de leitura", prossegue, “significa que o texto não é 'expressão de algo outro', anterior e independente dele" (idem). Isto acontece, segundo Costa Lima, "porque o texto contém um grau interno de indeterminação (Unbestimmtheit), que o distingue tanto de um teorema como de uma mensagem pragmática" (idem, 25). A qualidade da indeterminação, "que não é exclusiva do texto literário mas nele se acentua" (idem, 26), reconhece a "presença na cena textual de 'lugares vazios' (Leerstellen)", que podem ser definidos como "relações não-formuladas entre as diversas camadas do texto e suas várias possibilidades de conexão" (idem), cabendo ao leitor-interpretante "suplementar o(s) vazio(s) assim criado(s) pois do contrário o enredo não fluirá" (idem). Os lugares vazios, prossegue 
Costa Lima, "apresentam a estrutura do texto literário como uma articulação com furos, que exige do leitor mais do que a capacidade de decodificação" (idem), que diz respeito apenas "ao domínio da língua" (idem). O que é necessário, segundo o crítico literário brasileiro, é uma "participação ativa" do leitor, que "se choca com o entendimento tradicional da obra literária" (idem), baseada na concepção de que haveria uma única “interpretação correta" de uma escrita ficcional. Ao reconhecer a multiplicidade de interpretações de um mesmo texto, a partir de sua inerente camada de indeterminação, a Teoria da Recepção admite que o efeito estético é dado pela própria estrutura do texto, que "será atualizado de acordo com o 'horizonte de expectativas' (expressão não usada por Iser) de seu receptor" (idem). O aspecto lúdico é evidente nesse processo: conforme escreve Iser, "quanto mais o leitor é atraído pelos procedimentos a jogar os jogos do texto, tanto mais é ele também jogado pelo texto". Assim, de acordo com o teórico alemão, "novos traços de jogo emergem - ele assegura certos papeis ao leitor e, para fazê-lo, deve ter claramente a presença potencial do receptor como uma de suas partes componentes" (in LIMA: 2011, 116). Como resultado dessas premissas, Iser considera que "o jogo do texto, portanto, é uma performance para um suposto auditório e, como tal, não é idêntico a um jogo cumprido na vida comum, mas, na verdade, um jogo que se encena para o leitor, a quem é dado um papel que o habilita a realizar o cenário apresentado" (idem, 116). Nesse contexto, “o jogo encenado do texto não se desdobra, portanto, como um espetáculo que o leitor meramente observa, mas é tanto um evento em processo como um acontecimento para o leitor, provocando seu envolvimento direto nos procedimentos e na encenação" (idem). Ao jogar os jogos do texto, poderá o leitor produzir 'um 'suplemento' individual, que considera ser o significado do texto. O significado é um 'suplemento' porque prende o processo ininterrupto de transformação e é adicional ao texto, sem jamais ser autenticado por ele" (idem). Iser conclui o 
raciocínio afirmando que "a encenação (...) é basicamente um meio de transpor fronteiras e isso é igualmente verdadeiro para o jogo do texto, que encena uma transformação e, ao mesmo tempo, revela como se faz a encenação" (idem, 117). A diversidade de possibilidades interpretativas - cada uma delas entendida como jogo ou performance - em particular na tradução poética, será abordada em diferentes momentos de nosso trabalho, que utiliza conceitos e métodos da Teoria da Recepção de maneira livre, não-dogmática.

No primeiro capítulo da tese, estabelecemos um breve panorama da poesia japonesa desde o Manyoshu, antologia clássica publicada no século VII, durante o Período Heian, até Masaoka Shiki (1867-1902), que codificou o haicai como gênero literário. Ao longo do tópico, analisamos a concepção estrutural e os recursos estéticos empregados no haicai, conceitos da filosofia da arte japonesa e a relação entre poesia e caligrafia.

No segundo capítulo, abordamos o diálogo cultural entre Portugal e o Japão, iniciado no século XVI com a chegada de missionários cristãos nas ilhas japonesas. Relatamos os primeiros registros desse intercâmbio, como as obras publicadas pelo padre João Rodrigues, incluindo o Vocabulário da lingoa de Iapam, primeiro dicionário Japonês-Português, com 32 mil verbetes, e a Arte da lingoa de Iapam, que é, possivelmente, a primeira fonte de informação sobre a poesia japonesa divulgada em Portugal. O capítulo faz um registro histórico sucinto das tensões provocadas pela atividade evangelizadora nas ilhas japonesas até a ulterior expulsão dos missionários no Período Tokugawa, que culminou na interrupção do comércio, das relações políticas e culturais com os portugueses, que seriam retomadas apenas no século XIX, após a Restauração Meiji. Neste capítulo, destacamos a atividade de Wenceslau de Moraes, diplomata, oficial da marinha e escritor português que viveu em Tokushima e escreveu numerosas obras sobre a cultura japonesa, entre elas Relance da alma japonesa (1926), 
onde apresenta as primeiras traduções de haicais japoneses para a língua portuguesa. Por sugestão da profa. dra. Ida Alves, que participou de minha banca de defesa, realizada no dia 11 de dezembro de 2014 na Universidade de São Paulo, foi acrescentado um tópico sobre as traduções de oito elegias chinesas realizadas por Camilo Pessanha, contemporâneo e amigo de Wenceslau de Moraes.

No terceiro capítulo, analisamos o trabalho criativo de oito autores portugueses que dialogaram com diferentes aspectos da poesia e da cultura japonesas: Armando Martins Janeira, diplomata, ensaísta, autor de um livro fundamental - $O$ impacto português sobre a civilização japonesa - e de pioneiras traduções de peças de teatro nô para o português (incluindo Hagoromo, “O manto de penas"); Casimiro de Brito e Herberto Helder, poetas-tradutores que além de notáveis versões de haicais japoneses desenvolveram obras criativas próprias que conversam com a forma do terceto e também com o koan budista; Ana Hatherly e E. M. de Melo e Castro, poetas que trabalham com a caligrafia, o grafismo, o desenho e a pintura, em diapasão comparável ao da poesia escrita em caracteres ideográficos; Albano Martins e Eugênio de Andrade, poetas que conciliam a concisão, a elipse e a secura semântica (derivados, num primeiro momento, da leitura de poetas gregos e romanos) com a criação de densas paisagens verbais, próximas à concentrada imagética da poesia japonesa; e Yvette Centeno, poeta universalista que faz do haicai um polo de aglutinação, confronto e metamorfose de múltiplos códigos culturais. No final deste trabalho, apresentamos uma breve conclusão.

Meu interesse pela cultura japonesa é antigo - surgiu com a prática de artes marciais (aikidô, iaidô, esta última uma modalidade de esgrima com a lâmina de aço, ou kataná), a leitura intensa de Bashô, na tradução de Paulo Leminski, além do fascínio pelo cinema de Mizoguchi, Ozu, Kurosawa - e é claro, pelas delícias da culinária japonesa, sem dispensar o sakê. O tema desta tese nasceu, portanto, de uma confluência 
de meu interesse pela cultura japonesa e de minhas leituras de poesia portuguesa contemporânea, em especial de Ana Hatherly, tema de minha dissertação de mestrado, onde já abordei a relação entre os koans e as Tisanas e a presença da caligrafia nos Mapas da imaginação e da memória. Registro aqui, para finalizar a introdução, que foi o meu orientador, prof. Horácio Costa, que me apresentou às obras de Ana Hatherly e de Wenceslau de Moraes, além de me indicar instigantes caminhos de leitura e pesquisa. Concluídos os objetivos gerais desta Introdução - análise de conceitos teóricos da tradução criativa, exposição sucinta dos aspectos icônicos e analógicos da escrita ideográfica e sua ressonância em autores portugueses da segunda metade do século XX - convidamos agora o leitor para apreciar os três capítulos que compõem este trabalho.

Post scriptum: ao longo da tese, comentaremos também as traduções de haicais realizadas por Jorge de Sena e publicadas em sua notável obra em dois volumes Poesia de 26 séculos. Não dedicamos um capítulo específico à obra do memorável poeta, tradutor e ensaísta português por considerarmos que o seu diálogo com a poesia japonesa foi ocasional e circunscrito à atividade tradutória. Os autores portugueses abordados no terceiro capítulo deste trabalho - Armando Martins Janeira, Herberto Helder, Casimiro de Brito, Ana Hatherly, E. M. de Melo e Castro, Albano Martins, Eugênio de Andrade, Yvette Centeno - são apresentados e discutidos conforme a cronologia de publicação de obras relacionadas com a recepção da poesia japonesa, e não de acordo com suas datas de nascimento ou de geração literária. 


\section{CAPÍTULO I}

\section{A POESIA JAPONESA: FORMAS ESTRUTURAIS E REFERÊNCIAS CULTURAIS}

\section{1 - Origens}

A poesia lírica japonesa registra diversas modalidades de composição, como o tanka (短歌), surgido no século VIII, e o haicai (俳句), popularizado a partir do século XVI por Matsuo Bashô e seus discípulos. No presente capítulo, vamos analisar os gêneros tradicionais da poesia japonesa, sua história, formas estruturais e referências culturais, com especial atenção para a caligrafia, a visualidade da escrita ideográfica, a relação da poesia com outras formas artísticas, como a pintura, e os conceitos da filosofia da arte japonesa. O caldo de cultura relatado aqui de forma sucinta estará presente nas estratégias criativas adotadas pelos poetas portugueses em suas traduções da poesia japonesa e em seus próprios textos poéticos, assunto que será abordado no terceiro capítulo deste trabalho.

O primeiro registro da poesia clássica japonesa é a antologia Manyoshu (万葉集) ${ }^{32}$, cujo título já foi traduzido como "Livro das mil folhas", "Coleção de duas mil ideias" e "Livro de dez mil palavras" (SUZUKI: 1979, 11), publicada no século VIII, durante o Período Heian (794-1192). Conforme escreve Eico Suzuki no livro A literatura japonesa, esta coletânea, dividida em vinte volumes, reúne “4.500 poemas, classificados de acordo com os temas. O mais antigo poema é de amor, composto pela princesa Iua, esposa do imperador Nintoku (...), no começo do quinto século" (SUZUKI, 1979: 11). O grande número de composições poéticas de temática amorosa presentes na antologia, explica Suzuki, deve-se ao fato de que, na antiga sociedade aristocrática japonesa,

\footnotetext{
32 Os poemas dessa antologia estão sendo traduzidos para o português pela profa. Geny Wakisaka, diretora do Centro de Estudos Japoneses e coordenadora do curso de Língua e Literatura Japonesa da Universidade de São Paulo (USP).
} 
orientada por rígidas normas de conduta, "o namoro se faz por troca de poemas de parte a parte" (idem). Ao longo de 450 anos, o Manyoshu recebeu acréscimos de poetas de diferentes classes sociais, desde a família imperial até "damas e nobres, monges, guerreiros, a plebe, até mendigos, sendo numerosos os autores desconhecidos" (idem, 12). A poesia se manifesta como uma forma de expressão que transcende ou subverte o tecido social, como se fosse um território livre de imposições e normas específicas de conduta: "temas populares são abordados pela aristocracia, que se identifica com as camadas mais humildes, não havendo, pelo menos no sentimento e nas letras, divisão estanque entre elas" (idem). O Manyoshu reúne três modalidades de composição poética, a saber: o tchôca (長歌, poema longo), o tanka (短歌, poema curto) e o sedoka (旋頭歌, poema médio). De todos estes gêneros poéticos, o mais praticado é o tanka, do qual encontramos 4.207 composições no Manyoshu. O tanka clássico é formado por duas estrofes, um terceto de 5-7-5 sílabas e um dístico de 7-7 sílabas, sem rimas. Conforme diz o estudioso Shuichi Kato no livro Tempo e espaço na cultura japonesa, “o poema tanka é a única forma poética sistematizada reconhecida e promovida pela corte a partir do Período Heian, e que depois continuou sendo o estilo principal de expressão lírica da língua japonesa” (KATO, 2011: 84). O tanka é reconhecido como forma canônica no Manyoshu e também no Kokin Wakashu (古今和歌集) ou Antologia de poemas de ontem e de hoje, coletânea compilada por ordem imperial ${ }^{33}$ e publicado no século $\mathrm{X}$, que reúne mais de mil poemas, sendo apenas cinco tchôka, quatro sedoka e as demais composições pertencentes ao gênero tanka ${ }^{34}$. Esta será a forma por excelência

\footnotetext{
${ }^{33}$ Wenceslau de Moraes comenta que "durante o período medieval, isto é, desde o século $\mathrm{X}$ até o século $\mathrm{XV}$, tiveram publicidade, também por ordens dos soberanos, nada menos que vinte e uma antologias poéticas. Não faltam, pois, documentos que habilitem os curiosos, quando amplamente conhecedores da linguagem, a seguir a evolução da poesia japonesa”. (MORAES, 1926: 191)

${ }^{34}$ Conforme escreve Antônio Nojiri, essa modalidade poética, na época de seu surgimento, chamava-se waka, sendo que " Wa é uma outra leitura do ideograma Yamato, expressão designativa de Japão, e ka, outra leitura do ideograma uta, poema ou canto" (in AKIKO, 2007: 28).
} 
da poesia japonesa até meados do século XVI, sendo praticada ainda hoje por numerosos poetas, inclusive no Ocidente ${ }^{35}$. A evolução da poesia japonesa desde o Manyoshu, publicado no século VIII, até o Kokin Wakashu, que veio a lume 150 anos depois, não representou apenas "a concentração na forma poética curta" (idem, 85). Outras importantes mudanças são verificáveis na segunda antologia, como a adoção de pseudônimos poéticos (kana) em lugar dos nomes verdadeiros (mana) dos poetas, todos eles pertencentes à aristocracia japonesa, em contraste com a diversidade social verificada no Manyoshu. "Mudam também os recursos estilísticos" (idem), diz Shuichi Kato, com o uso frequente da aliteração, da assonância, da onomatopeia, do trocadilho, também encontrados nos textos poéticos das peças de teatro Nô, e a ênfase temática está no mono omoi (o "pensar nos fatos"). O Manyoshu cantava o amor (somon, "poemas de paixão") e a morte (banka, "elegia e canto fúnebre"), e ainda, nos poemas mistos, abordava "celebrações, viagens, ocorrências militares e, em número menor, até mesmo temas como a miséria, o imposto pesado e o saquê" (idem, 86). Já na antologia palaciana Kokin Wakashu foram banidos os temas relacionados à política e à bebida alcoólica, recorrentes na poesia chinesa - por exemplo, no Livro das odes coletadas por Confúcio, ou Shi king (詩) -, cuja influência estava caindo em desuso na lírica japonesa. Ocorre também "um contraste notável com a classificação das obras de acordo com o tipo de tema, e o surgimento do costume peculiar em classificar os poemas líricos de acordo com as "quatro estações"” (idem, 85). Com efeito, como diz Shuichi Kato, "um terço dos mais de mil poemas dos vinte rolos do Kokin Wakashu é composto de poemas de amor, e outro terço, de poemas das quatro estações. Desde então, muitas antologias seguiram o exemplo" (idem, 86). O critério de dividir os poemas de um livro de acordo

\footnotetext{
${ }^{35}$ No Brasil, Wilson Bueno publicou dois livros de tankas: Pequeno tratado de brinquedos (São Paulo: Iluminuras, 1996) e Pincel de Kyoto (Bauru: Lumme Editor, 2008).
} 
com a estação do ano é um elemento específico da literatura japonesa, não encontrando correspondentes na China ou em países europeus. (A temática sazonal, porém, encontrase em muitos poemas chineses, especialmente da dinastia Tang, 618-907 d.C., como na conhecida composição de Li T'ai Po - ou Li Bai -, traduzida por Sérgio Capparelli e Sun Yuqi: "Cobre-se de geada / a escadaria de jade. / O frio úmido da noite / entranha em suas meias de seda. / Ela solta o cortinado / e através dos cristais translúcidos / contempla a lua de outono”, CAPPARELLI e YUQI, 2012: 75). É uma prática que transporta, para o campo da poesia, o conceito de tempo na cultura japonesa, que não obedece a uma lógica evolutiva linear, do tipo início-meio-fim, mas a um princípio cíclico; por isso mesmo, sua representação gráfica poderia ser um círculo ou espiral infinita. O pensamento tradicional japonês sobre o tempo remonta, provavelmente, à observação das estações pelos camponeses, que obedeciam ao ritmo sazonal para a semeadura e a colheita. As estações, que regem a agricultura, a pesca, os ritos religiosos, festas e cerimônias eram os sinais visíveis de uma ordenação do cosmo, da natureza e do próprio homem. "Na parte oeste da ilha principal do arquipélago japonês e na ilha de Kyoshu - ou seja, na região que foi o centro da cultura antiga - a distinção das estações é clara, é regrada", escreve Shuichi Kato, "e não é difícil imaginar que essas mudanças que se sucedem naturalmente possam ter definido uma consciência do tempo cotidiano da sociedade agrícola" (idem, 49). O trabalhador rural japonês percebeu que as quatro estações se sucedem e que os fenômenos naturais não acontecem uma única vez. "Não é que o tempo das quatro estações avance em linha reta, ele dá voltas em uma circunferência, e nela não há começo ou fim” (idem, 87).

A percepção do tempo cíclico pelos agricultores japoneses foi absorvida pela corte Heian, a partir do século XI, tornando-se o principal recurso de expressão para os poetas 
e escritores. O conhecido Makura no Soshi (枕草子), ou Livro do travesseiro ${ }^{36}$, escrito entre os anos de 994 e 1001 pela dama da corte Sei Shonagon, começa com estas palavras: "Da primavera, o amanhecer. (...). Do verão, a noite. (...) Do outono, o entardecer. (...) Do inverno, o despertar”. (SHONAGON, 2013: 45). Outra obra célebre, de natureza épica, o Heike Monogatari (平家物語), ou Narrativas do clã Taira, do século XII, também começa com uma invocação sobre a efemeridade de todas as coisas, onde a ideia do tempo cíclico alia-se à noção da impermanência dos fenômenos. Na poesia do gênero tanka, a referência sazonal indica o momento em que os versos foram escritos, a atitude mental do autor, ao observar ou participar de uma ação, e os sentimentos relacionados a essa paisagem. Assim, a "primavera" pode estar associada ao "perfume da ameixa", ao "canto do rouxinol" ou à lembrança da "amada", o “outono" pode estar acompanhado pelo "corvo", "solidão", "vento" e assim por diante. O princípio da analogia entre as quatro estações, os acontecimentos na natureza e as atitudes e emoções humanas é o coração do tanka, que a partir da antologia Kokin Wakashu "tornou-se uma forma de transmissão social do pensamento e, por outro lado, um meio de entretenimento" (KATO, 2011: 89), sintetiza Shuichi Kato.

\section{2 - Do tanka ao haicai}

A forma clássica do tanka, composta de um terceto e um dístico, totalizava 31 sílabas, sem rimas. Conforme diz Paulo Franchetti, em seu livro Haikai, a relação entre

\footnotetext{
${ }^{36}$ O livro de Sei Shonagon também é conhecido como Livro de cabeceira (título, aliás, do filme do diretor inglês Peter Greenaway que dialoga com essa obra). Wenceslau de Moraes faz um comentário interessante a respeito: "Em minha opinião e pelo pouquíssimo que conheço de tão complicado assunto, o livro de impressões Makura no Sôshi (Notas de travesseiro), publicado cerca do ano 1000 e do qual é autora a dama da corte Sei Shonagon, é um dos mais atraentes, se não o mais atraente de todos os primores literários do período de Heian, o que quer dizer - de toda a literatura japonesa; -- direi mais nunca li nenhum livro de impressões, em qualquer literatura ocidental, que tanto me deleitasse como este". (MORAES, 1926: 182-183)
} 
as duas estrofes de um tanka não apresenta "um claro nexo lógico", e os poemas em que isso ocorre "são usualmente considerados de segundo nível" (FRANCHETTI, 1990: 1112). Os procedimentos mais recorrentes, prossegue o autor, "são ou a justaposição direta de imagens de alguma forma complementares ou a utilização da shimo-no-ku (下の句, estrofe de baixo) para apresentar uma espécie de comentário ou exemplificação do clima geral estabelecido na kami-no-ku (上の句, estrofe de cima)”. Um bom exemplo da forma de composição do tanka é este poema de Ki no Tsurayuki (868-945):

Cheio de saudades,

Vou encontrar a minha amada:

Na noite de inverno

$\mathrm{O}$ vento do rio é gelado

E gritam as aves noturnas.

Tradução: Paulo Franchetti ${ }^{37}$

No dístico inicial, há um eu lírico que manifesta saudades da amada e a intenção de encontrá-la; já no terceto, surge uma paisagem composta pelo vento de inverno, o rio gelado e as aves noturnas, sem nenhuma voz lírica, como se fosse a montagem de duas sequências cinematográficas, sem uma ligação discursiva ou narrativa entre elas. A não explica B, uma estrofe não afirma, nega ou contradiz a outra, mas sugere um clima, um estado de espírito, algo incorpóreo que não se materializa no texto, mas que é suscetível de diferentes interpretações, de acordo com o repertório e a sensibilidade do leitor.

A estrutura do tanka permitia que dois poetas participassem na criação do mesmo poema: um escrevia o terceto e o outro o dístico. Com o passar do tempo, começaram a surgir séries inteiras de poemas escritos por diversos poetas, num jogo semelhante ao “cadáver delicado" dos surrealistas que passou a ser conhecido como renga (连歌). Conforme Shuichi Kato, “o renga é uma produção conjunta de muitas pessoas, na qual

\footnotetext{
${ }^{37}$ (in FRANCHETTI, 2012: 11)
} 
ninguém pensa na estrutura como um todo, apenas concentra a atenção em como compor da melhor forma possível a estrofe a ser acrescida em cada uma das situações" (KATO, 2011: 94). Nessa aparente brincadeira estilizada, "cada um faz uma estrofe relacionada exclusivamente à última estrofe composta, sem nenhuma necessidade de considerar as estrofes anteriores." (idem). O fluir do encadeamento poético não é planejado, segundo o estudioso japonês, uma vez que "ele segue conforme as ideias que surgem no momento, ora mudando-se o tema, ora o cenário, ora a emotividade (idem)." O encanto desse jogo poético, tanto para o poeta quanto para o público, está no "encontro inesperado", na "engenhosidade" e na "retórica" de cada estrofe apresentada (idem). "Resumindo, a graça está na relação que se estabelece entre as duas estrofes que está bem diante de nossos olhos. A graça é concluída no presente, e não se liga nem ao passado nem ao futuro. O renga é o estilo literário que vive no 'agora = aqui'." (idem).

Donald Keene compara o poema encadeado japonês ao emakimono (絵巻物), "pintura realizada sobre uma faixa de papel manuseada como os antigos pergaminhos, enrolando-se de um lado a mesma extensão que se desenrola de outro; cada seção sob a nossa vista tem unidade e sentido, mas o rolo todo, se desdobrado, não teria mais coesão e coerência" (in FRANCHETTI: 1990, 14). O novo estilo poético desenvolveu-se nas cortes aristocráticas japonesas, sendo praticado, inclusive, pelo xogum Minamotono Sanetomo (1192-1210), e se torna "uma das principais atividades de salão da aristocracia medieval japonesa e o veículo por excelência do namoro cortesão" (FRANCHETTI: 1990, 13). Segundo o Taiheki (太平記), ou Registros da grande paz, obra escrita no século XIV, no período das guerras civis, “a força militar que cercava o castelo e esperava a reação do adversário passou a realizar reuniões de renga nos locais de acampamento" (idem, 93). A composição de poemas encadeados atinge o seu 
momento de apogeu entre o final do Período Kamura e o início do Período Muromachi (1333-1600), e o mestre que se destaca é Sôgi (1421-1502), autor de versos como estes, na versão de Paulo Franchetti: "Fim da tarde: / Ainda há neve e as encostas da montanha / Estão cobertas de névoa ${ }^{38 " ~(F R A N C H E T T I, ~ 1990: ~ 13) . ~ A ~ p a r t i r ~ d o ~ s e ́ c u l o ~}$ XIV, diz o autor brasileiro, "se estabelecem inúmeras regras para a elaboração do renga longo (kusari renga, 鎖連歌), das quais as mais importantes para nós são as que se referem à primeira estrofe - o hokku (発句) -, pois elas continuam vigendo no que hoje conhecemos como haikai ou haiku (俳句)". A estrofe inicial, prossegue o autor, deveria ter dezessete sílabas, "conter sempre uma referência à estação do ano e ao lugar onde se realizou a sessão; e ser sintaticamente completo, independente da estrofe seguinte". (FRANCHETTI, 1990: 13). Com o passar do tempo, o renga torna-se um passatempo de corte altamente estilizado, submetido a numerosas regras, e cai no artificialismo e na frivolidade. “À medida que se esterilizava como mera atividade cortesã", escreve Octavio Paz,

o renga clássico começou a ser substituído nos meios externos à corte por um tipo de poema coletivo que, embora utilizando a mesma forma, elimina a maior parte das regras complicadas, admite o uso de palavras de origem chinesa e se compraz no trocadilho, no dito espirituoso e no humor (PAZ, 1996: 157-158).

O novo gênero literário, chamado renga haikai (俳諧の連歌, versos ligados 'cômicos', informais), "ganhará popularidade principalmente em reuniões da ascendente classe de comerciantes", mas também será praticado "entre soldados, monges e mesmo entre nobres, em situações em que não impere a etiqueta da corte" (idem). Um exemplo de renga haikai é esta série de poemas, citada pelo autor mexicano no mesmo ensaio:

El aguacero invernal incapaz de esconder a la luna la deja escaparse de su puño

\section{TOKOKU}

\footnotetext{
${ }^{38}$ In FRANCHETTI, 1990: 13.
} 
Mientras camino sobre el hielo

piso relámpagos: la luz da mi linterna.

JUGO

$\mathrm{Al}$ alba, los cazadores

atan a sus flechas

blancas hojas de helechos.

YASUI

Abriendo de par en par

la puerta norte del Palacio: la Primavera!

BASHÔ

Entre los rastrillos

y el estiércol de los caballos

humea, cálido, el aire.

KAKEI $^{39}$

(in PAZ, 1996: 158)

A transformação do renga clássico, de feição aristocrática, numa forma popular, de linguagem coloquial, deve-se aos poetas Arakida Moritake (1473-1549) e Yamazaki Sokán (1465-1553). A arte praticada por estes mestres, segundo o poeta e ensaísta mexicano, "opôs à tradição cortesã e requintada do renga um saudável horror ao sublime e uma perigosa inclinação pela imagem artificiosa e o jogo de palavras (o trocadilho)" (idem, 173). A nova modalidade de renga trouxe à poesia a linguagem coloquial, urbana, das grandes cidades japonesas e, como observa Shuichi Kato, "voltou-se para as experiências concretas e versáteis dos assuntos do dia-a-dia" (KATO: 2011, 93), constituindo uma "revolução poética semelhante, neste sentido, às que

\footnotetext{
${ }^{39}$ Sebastião Uchoa Leite assim traduziu para o nosso idioma: "O aguaceiro invernal / incapaz de esconder a lua / deixa-a escapar-se de seu punho" (TOKOKU); "Enquanto caminho sobre o gelo / piso relâmpagos: a luz da minha lanterna" (JUGO); "Na aurora, os caçadores / atam às suas flechas / brancas folhas de feto" (YASUI); "Abrindo de par em par / a porta norte do Palácio: / a Primavera!" (BASHÔ); "Entre os rastelos / e o esterco dos cavalos / fumega, cálido, o ar" (KAKEI). (in PAZ, 1996: 158)
} 
ocorreram no Ocidente, primeiro no período romântico e depois em nossos dias" (PAZ, 1996: 173). A inclusão da fala das ruas numa arte de origem aristocrática, segundo Paz, significa a "irrupção do elemento histórico e portanto crítico na linguagem poética" (idem). Com o passar do tempo, o terceto que fazia parte do tanka e do renga, chamado hokku, ganhou vida própria, tornando-se um novo gênero poético, conhecido como haikai ou haiku. Duas escolas poéticas se desenvolvem, a partir daí: a Teimon (貞門(ていもん), de Matsunaga Teitoku (1571-1653), que tentou regressar à linguagem poética convencional do antigo renga, e a Danrin (談林派(だんりんは), liderada por Nishyama Soin (1605-1682), que mantém o humor e a linguagem popular. Como exemplos antitéticos dessas escolas, citamos dois poemas, traduzidos por Octavio Paz:

Hora del tigre:

niebla de primavera

también rayada!

(Teitoku)

Lluvia de mayo: es hoja de papel el mundo entero

$(\text { Soin })^{40}$

(in PAZ, 1996: 174)

O poema de Teitoku é metafórico e cria uma imagem inusitada, de certa beleza poética - a névoa rajada como o tigre - mas afastada da natureza e sem um sentido existencial que transcenda o mero artifício imagético. Conforme Paulo Franchetti, a escola de Teitoku, conhecida como Teimon (Teitoku + mon, escola, maneira), “almejava elevar o

\footnotetext{
${ }^{40}$ Sebastião Uchoa Leite assim traduziu esses poemas para o nosso idioma: "Hora do tigre: / névoa de primavera / também rajada" (Teitoku) e "Chuva de maio: / é folha de papel / o mundo inteiro" (Soin) (in PAZ, 1996: 174).
} 
haikai a um nível de realização estética semelhante ao do waka ${ }^{41}$ ", (FRANCHETTI, 2012: 16) e por isso evitava os termos vulgares, o humor pesado e a informalidade que caracterizavam sua rival, a Danrin (em tradução literal, "floresta falante"), liderada por Soin (1604-1682). O segundo poema de Soin, atira o dardo em outra direção e usa uma imagem simples para estabelecer uma relação entre a fragilidade da folha de papel e a impermanência dos fenômenos, tema caro à filosofia zen-budista. A liberdade formal de Soin foi possível graças à "ação demolidora de Sokan (1458-1546), que, no século anterior, praticou um verdadeiro terrorismo contra as boas maneiras do tanka" (idem), escrevendo versos como estes:

A roupagem da névoa

Está molhada nas barras.

A deusa Saho, Quando chega a primavera, Urina de pé.

Tradução: Paulo Franchetti ${ }^{42}$

Poetas como Soin, Sokan e Moritake são os precursores daquele que seria reconhecido como um dos maiores poetas do Império do Sol Nascente: Matsuo Bashô (1644-1694). Sob a influência de "um pensamento religioso sincrético, em que o animismo xintoísta convive com a doutrina budista do mundo como ilusão e sofrimento $^{43}$ " (FRANCHETTI, 1990: 19), Bashô fez do haicai um severo exercício

\footnotetext{
${ }^{41}$ Waka (和歌), modo como era conhecida a poesia japonesa. Wa é outra leitura do ideograma Yamato, 大和, que designa o Japão, e $k a$ significa poema ou canto.

42 (in FRANCHETTI, 2012: 17)

${ }^{43} \mathrm{O}$ xintoísmo é uma religião originária do arquipélago japonês (ao contrário do budismo, que surgiu na Índia, e do confucionismo, importado da China) que remonta à pré-história. Enfatiza o culto aos antepassados, aos espíritos da natureza (kami) e aos deuses da mitologia japonesa, em especial Izanagi e Izanami, o casal divino que deu origem ao universo, e Amaterasu, a deusa do Sol. O imperador também era adorado como um deus vivo, prática que subsistiu até a derrota do Japão na II Guerra Mundial, quando Hiró́oto fez um pronunciamento radiofônico reconhecendo a sua humanidade. O xintoísmo também é conhecido como Kami no michi ("caminho dos deuses").
} 
espiritual, quase uma ascese. "A obra capital de Bashô", escreve Paulo Franchetti, "foi a elevação do haikai ao estatuto de um michi, um dô, isto é, um caminho de vida, uma forma de ver e de viver o mundo" (FRANCHETTI, 1990: 18)." “A partir do estabelecimento da Shomon (Bashô + mon, escola, maneira)", prossegue, "o haikai passa a ser um equivalente do Sadô - o caminho do chá - enquanto forma iniciática de disciplina e de exercício espiritual (idem).” Bashô não rompe com a tradição nem cria novas formas poéticas ("Não sigo o caminho dos antigos; busco o que eles buscaram", in PAZ: 1996, 156), mas transforma o sentido do haicai, que deixa de ser um divertimento frívolo para se tornar expressão da mais alta poesia, em que se destacam elementos como a observação rara ("chuva de primavera / a água escorre do teto / pelo ninho de vespas ${ }^{44, "), ~ a ~ d e s m e s u r a ~(" o ~ d i a ~ e m ~ c h a m a s ~ / ~ j o g a ~ n o ~ m a r ~ / ~ o ~ r i o ~ m o g a ̂ m i ~}{ }^{45, "), ~ o ~}$ humor e a coloquialidade ("pulgas piolhos / um cavalo mija / do lado do meu travesseiro ${ }^{46 ”}$ ), a compaixão e benevolência budistas (“em minha cabana / tenho o que oferecer pelo menos / os mosquitos são pequenos ${ }^{47,}$ ) e o profundo sentimento de solidão (“do orvalho / nunca esqueça / o branco gosto solitário ${ }^{48 ”) . ~ M a s ~ o ~ q u e ~ v e m ~ a ~ s e r, ~}$ exatamente, o novo gênero poético - o haicai - que Bashô transforma numa arte em que "o pessoal e o impessoal, o alto e o baixo, o elegante e o grotesco compõem um mesmo mundo, cheio de sentido e de vida?" (FRANCHETTI, 1990: 16).

\subsection{O haicai}

\footnotetext{
${ }^{44}$ LEMINSKI: 1983, 51.

${ }^{45}$ Idem.

${ }^{46}$ Idem, 52.

${ }^{47}$ Idem, 54.

${ }^{48}$ Idem, 64.
} 
O haicai ou haiku (俳句) é o poema breve japonês composto de três versos, de cinco, sete e cinco sílabas, sem rimas ou título, geralmente inserido num diário de viagem (俳文, haibun) ou numa pintura (禅画, zen-ga) ${ }^{49}$. Escrito no alfabeto de ideogramas (漢字, kanjis), que representam figuras abreviadas, e em dois sistemas fonéticos, o hiragana (平仮名, que registra palavras japonesas que não se utilizam de caracteres chineses) e o katakana (片仮名, usado para registrar palavras estrangeiras) e desenhado em refinada caligrafia, o haicai não era uma arte exclusivamente verbal, mas uma síntese de texto e visualidade. Os versos são dispostos em "uma, duas, três ou quatro linhas verticais, segundo as conveniências do quadro em que se inserem e/ou ênfase que o calígrafo quiser dar a uma palavra ou frase" (FRANCHETTI, 1990: 33), e a leitura é feita na vertical, da direita para a esquerda, ao contrário do que acontece nos idiomas ocidentais. Criação intersemiótica orientada por princípios de economia construtiva e alta definição de contornos, o haicai é a representação direta do mundo dos fenômenos, em linguagem substantiva e dicção coloquial, ainda que a presença do inusitado, do humor e a própria estrutura da língua japonesa criem sensações de estranheza e imprevisto, como no conhecido poema de Bashô: "velha lagoa / o sapo

\footnotetext{
${ }^{49}$ A forma padronizada do haicai nas traduções para línguas ocidentais é o terceto de 5-7-5 sílabas, embora em japonês os versos possam estar dispostos em uma única linha, divididos por palavras de corte, ou kireji. Segundo Paulo Franchetti, "Os kireji mais comuns são: kana, ya e keri. Kana é uma partícula pospositiva que indica emoção. Na realidade, sua principal função é fazer com que a palavra antecedente seja vista como o foco do poema, o núcleo em torno do qual se constela a energia poética. Por ser uma partícula muito marcante, aparece nas últimas sílabas de uma estrofe. Em nossa tradição equivale a um ponto de exclamação, a uma interjeição como 'ah' (...). Ya também pode indicar emoção ou suspensão do pensamento e, em certos casos, dúvida. Ocorre normalmente na quinta sílaba e o mais das vezes funciona apenas como uma espécie de pausa. Em nossa tradução, foi substituída por um travessão (-) ou por dois pontos (:) (...). Finalmente, -keri, utilizado para indicar que uma ação se concluiu e que daí resultou alguma emoção ou sensação relevante para o sentido do poema." (FRANCHETTI, 1990: 33-34)
} 
salta / o som da água ${ }^{50,}$, que o olhar semiótico de Barthes reconheceu como um irônico jogo de imagens entre maior (a lagoa) e menor (o sapo). Conforme diz Paulo Leminski em sua biografia do poeta japonês, o primeiro verso de um haicai "expressa em geral uma circunstância eterna, absoluta, cósmica, não-humana, normalmente uma alusão à estação do ano, presente em todo haicai” (LEMINSKI, 1983: 44). O autor cita, como exemplos de kigo (季語), o signo da estação ano, versos como "lua de outono", "vento de primavera" e "tempestade de verão", que fazem parte de numerosos poemas do cânone japonês. O segundo verso do haicai, segundo Leminski, "exprime a ocorrência do evento, o acaso da acontecência, a mudança, a variante, o acidente casual. Por isso, talvez, tenha duas sílabas a mais que os outros" (idem, 45). A terceira linha do haicai, por fim, "representa o resultado da interação entre a ordem imutável do cosmo e o evento. Resultado distinto da conclusão de um silogismo da lógica grega aristotélica" (idem). "No poema japonês", prossegue o autor, "não há 'logo', 'portanto' nem ‘contudo'. As articulações sintáticas são soltas, ambíguas em suas funções lógicas, abertas, plurais.” (idem). Barthes, por sua vez, observou que no haicai não há descrições, nem definições, elementos básicos na comunicação ocidental: "sem descrever nem definir, o haicai (...) emagrece até a pura designação. (...) O sentido é apenas um flash, um arranhão de luz" (BARTHES, 2007: 112). Os três versos do haicai, como as três varetas de um arranjo floral, ou ikebana (生け花), estabelecem uma relação entre o Céu (Shin), o Homem (So) e a Terra (Gyo) (Figura 1), vale dizer, entre o eterno e o efêmero, resumindo a filosofia zen-budista ${ }^{51}$, que enfatiza a interdependência

\footnotetext{
${ }^{50}$ In LEMINSKI, 1983: 20.

${ }^{51}$ Conforme Ricardo M. Gonçalves, em seu livro Textos budistas e zen-budistas: "O budismo foi introduzido oficialmente no Japão no ano 538, no reinado do imperador Kinmei. A grande figura dos primeiros tempos do Budismo nipônico foi o príncipe Shotoku (574-622), que deu ao Japão sua primeira lei escrita, inspirada em ideais budistas, mandou missões de estudo à China, a fim de promover uma
} 
entre todas as coisas do universo e, ao mesmo tempo, a mutabilidade e a impermanência

dos fenômenos, regidos pelo tempo cíclico.
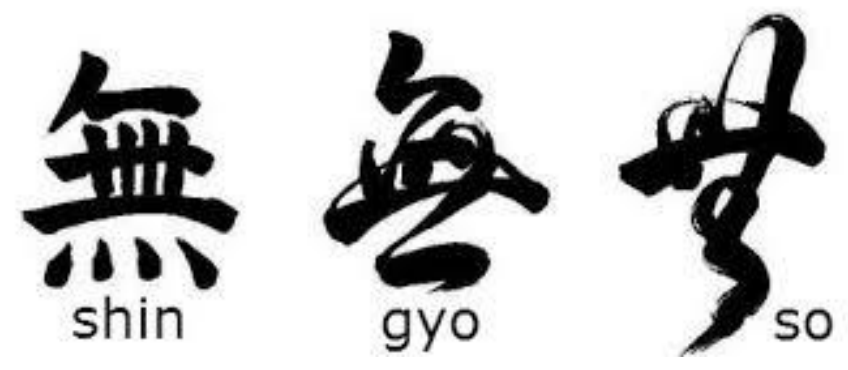

\section{Figura 6}

A representação da impermanência é essencial nas artes tradicionais japonesas,

como os arranjos florais (生け花, ikebana), a caligrafia (書道, shodô) e a pintura (墨絵,

sumiê), que ressaltam a brevidade da existência do homem e das coisas e a contínua

transformação no devir temporal, em que a única realidade imutável é o Vazio do estado

absorção intensa da cultura continental, na qual o Budismo figurava em primeiro plano, e escreveu ele próprio comentários aos principais sutras do Maaiana. Do século VI ao século IX, o Budismo nipônico foi quase que exclusivamente uma religião do estado, destinada a reforçar o prestígo político do imperador. Em torno de Nara, a primeira capital do Japão, floresceram grandes mosteiros, em que numerosos monges se entregavam a profundos estudos filosóficos e celebravam rituais mágico-religiosos, visando à prosperidade do Estado e à glória da casa imperial. (...) No século IX, com a mudança da capital para Quioto, começa uma nova fase para o Budismo no Japão. As principais figuras desse século foram Saichô, também chamado Denkyo Daishi (767-822), e Kukai, também chamado Kôbo Daishi (774-835 ). O primeiro introduziu no Japão a escola Tendai e fundou o famoso mosteiro de Enryakuji, no Monte Hiei, próximo a Quioto, de onde saíram os principais mestres do Budismo japonês. A escola Tendai tem por especial característica o ecletismo, fundindo harmoniosamente as doutrinas da escola chinesa Tien-Tai, baseadas no Sutra do Lótus da Boa Lei, com elementos do Zen-Budismo, da Escola Devocional da Terra Pura e do Budismo Esotérico. Kukai, além de ter introduzido no Japão o Budismo Esotérico, com o nome de Escola Shingon, desenvolveu intensa atividade literária, deixando muitos poemas, tratados filosóficos e novos estilos de caligrafia. Notabilizou-se também como educador, cabendo-lhe o mérito de criar no Japão a primeira escola destinada a fornecer educação gratuita às classes populares, o Shugeishuchi-in, numa época em que a educação era monopólio exclusivo das classes dominantes em todo o mundo. (...) Finalmente, temos o Zen-Budismo, nos seus dois principais ramos, Soto e Rinzai. O Movimento Rinzai foi introduzido por Eisai (1141-1251), tendo encontrado grande aceitação por parte da nobreza guerreira do Japão feudal. (...) O movimento Soto foi introduzido por Dooguen (1200-1253), que teve seus primeiros contatos com o Zen como discípulo de Eisai, tendo posteriormente viajado à China, onde se iniciou na escola Soto com o mestre Tendo Nyojo. (...) A história do Budismo japonês depois do século XIII nada mais é que a história do desenvolvimento das escolas fundadas anteriormente. Ao passo que o Budismo Zen se difundia entre a classe guerreira, influenciando decisivamente o desenvolvimento das artes, da moral feudal e da cultura em geral, as escolas devocionais encontraram grande aceitação entre as classes populares." (GONÇALVES, 1999: 25-28) 
búdico, ou sunyata ${ }^{52}$. Na pintura sumiê, por exemplo, notamos a valorização do espaço vazio, do traço imperfeito, inacabado ou borrado, que coloca em primeiro plano o contorno abreviado das figuras, e não os volumes. A tensão entre preciso e impreciso, presença e ausência, concreto e abstrato, real e imaginado é frequente nesse repertório cultural e deriva das concepções filosóficas do taoísmo chinês, do Tao te king (道德經) e do I king ou I ching ${ }^{53}$ (易經), que abordam a perfeição do imperfeito, do inacabado ou desfeito, índices da fugacidade da matéria e do tempo. A interferência criativa do acaso na elaboração da obra de arte e a ação intuitiva do artista são outros elementos valorizados na arte japonesa, porque remetem à simplicidade, à espontaneidade, à naturalidade, rompendo com as limitações da lógica rotineira e das convenções formais. Um mestre, no sentido japonês da palavra, não é aquele que maneja com habilidade as técnicas de composição poética, de pintura à nanquim ou de luta com a espada, mas sim aquele que, tendo assimilado essas técnicas, superou o mero domínio formal, atingindo a arte sem arte, ou criação natural e sem artifícios, que corresponde ao ideal zen-budista de desapego e volta à natureza original da mente, que é o estado de vacuidade, ou sunyata, a harmonia que transcende todas as oposições entre sujeito e objeto, o interno e o externo, o efêmero e o eterno. Outro princípio importante é yugen (幽玄), que significa "mistério", "charme sutil". Os dois ideogramas que compõem a palavra significam, respectivamente, mistério e obscuridade. Segundo Darci Yasuco Kusano, "yugen possui um significado além das aparências" (KUSANO: 1987, 22). "Os fatores

\footnotetext{
${ }^{52}$ Sunyata, segundo Ricardo M. Gonçalves, é "o real incondicionado por trás de todos os fenômenos impermanentes e relativos" (idem, 16). Quando o praticante budista obtém essa compreensão e logra "desapegar-se dos fenômenos impermanentes e relativos, aceitando-os como tais, assumindo a transformação de si mesmo e de todas as coisas, com todas as suas consequências" ele "experimenta o Nirvana, isto é, o incondicionado, que Buda não define, limitando-se a dizer que ele é caracterizado pela repressão do sofrimento e de suas causas, a ignorância, a cólera e as paixões descontroladas" (idem).

${ }^{53}$ King ou ching, em chinês, significa "livro clássico".
} 
primordiais que constituem o yugen são a beleza e a elegância, aliadas à suavidade; o

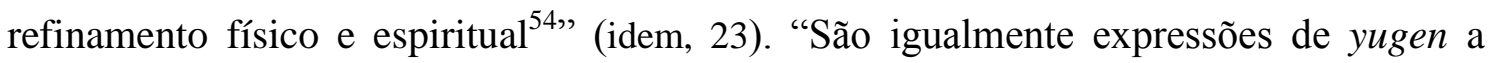
beleza ideal, sublime, com uma aura de mistério" (idem). Um haicai tem yugen se ele consegue abordar um assunto de maneira inusitada, mas com sutileza, sem ostentação ou vulgaridade. Assim, por exemplo, neste poema de Bashô: "dia de finados / do jeito

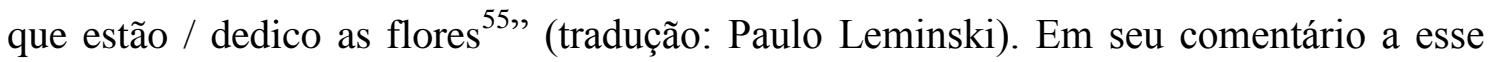
poema, o tradutor diz: "Na festa de Ulambamma, os japoneses homenageiam os mortos. Neste dia, todos colhem flores para levar aos que já se foram. Bashô, também: é um budista, articulado com os ritos da tribo" (LEMINSKI: 1983, 14). Porém, no haicai que escreve em homenagem aos mortos, o poeta apresenta uma "subversão súbita: as flores que vê, Bashô as oferece sem tirá-las do pé. Uma afirmação de vida: um sim para a poesia" (idem).

Dois conceitos essenciais da filosofia da arte japonesa, que comentaremos a seguir, são os de wabi e sabi (侘寂), presentes em todas as artes tradicionais influenciadas pelo zen-budismo, desde a poesia, arquitetura e pintura até os arranjos florais e a cerimônia do chá. Sabi é o conceito que se aplica a poemas caracterizados pelo clima de solidão e de tranquilidade. Um texto tem sabi quando mostra a calma, a resignada solidão do homem em meio ao universo. Conforme Hammitzsch, "a imagem de uma simples cabana, possivelmente solitária, um nobre cavalo amarrado; este é o sabi" (HAMMITZSCH, 1993: 61). O que caracteriza o conceito de sabi, conforme o autor alemão, "é a ausência de uma beleza óbvia; é a beleza do incolor em contraste com a beleza resplandecente; é a beleza do transitório contrastando com a beleza do

\footnotetext{
54 "Yasunari Takahashi, num estudo literário de cunho semiótico, opina: 'Etimologicamente, poderia significar algo sombrio e escuro, mas o que o termo realmente implica é a beleza crepuscular, antes do que o terror e o desespero da extrema escuridão. Esse crepúsculo seria, para Zeami, uma metáfora atenta no seu mais profundo grau'." (CAMPOS, 1993: 25-26)
} 
exuberante; é a beleza enrugada, porém sábia, da idade, diante da beleza cheia de forças, mas imatura, da juventude" (idem, 62). Sabi sugere também “tornar-se sereno, estar só, a solidão profunda" (idem). Um bom exemplo de sabi é este poema de Kobayashi Issa, cheio de recolhimento e interiorização: "Em solidão, / como a minha comida / e sopra o vento de outono ${ }^{56 "}$ (tradução: Paulo Franchetti), ou ainda, este da poeta e monja budista Chiyo-Ni: “colchão de mendigo / cheio de graça / vozes dos grilos ${ }^{57 ”}$ (tradução: Alice Ruiz, a partir da versão em inglês de R. H. Blyth: "The nightly couch of the beggar / how lively and gay / with voices of insects $\left.{ }^{58, "}\right)$. Wabi também significa solidão, mas desta vez com referência à vida do eremita, do asceta. Designa a tranquilidade da pobreza voluntária, do despojamento que liberta o espírito dos desejos que prendem ao mundo. A arte que tem wabi trabalha com o mínimo de elementos, apenas com aqueles suficientes para indicar a integração entre homem e universo. É a perfeição do imperfeito, a beleza do assimétrico, humilde, irregular, que corresponde à visão budista da realidade como algo efêmero e mutável. "Os ensinamentos do zen e, do mesmo modo, o Caminho do Chá, valorizam a assimetria, pois só ela é livre de repetições, propiciando um desenvolvimento criativo", escreve Hammitzsch. "Além do mais, a simetria nos faz sentir, de um modo muito forte, o momento da perfeição, e não é isso o que se deseja.” (idem, 114) Sen Sotan, no tratado Zencharoku (禅茶録), afirma que “O verdadeiro wabi é incompleto, não tem nenhum desejo próprio, nem anseio algum de perfeição" (in HAMMITZSCH, 1993: 98). Um exemplo de wabi é o jardim de pedra e areia de um conhecido templo budista em Kyoto. Podemos lembrar também da seguinte

\footnotetext{
${ }^{55}$ LEMINSKI, 1983: 14.

${ }^{56}$ In FRANCHETTI, 1990: 141.

${ }^{57}$ RUIZ, 1981: 13.

${ }^{58}$ BLYTH, 1981: 257 (primeiro volume).
} 
história tradicional: convidado por um nobre poderoso a mostrar sua perícia na arte dos arranjos florais, o mestre Riyoki é recebido no palácio, mas entregam a ele apenas as flores e uma bacia de água, sem os apetrechos necessários para se fazer o arranjo. Em poucos minutos, porém, Riyoki cortou as pétalas e as dispôs de maneira harmônica na água da bacia, com elegância e beleza. Numerosos poemas de Bashô, Issa e Buson têm o espírito de wabi, mas um poema que se destaca pela força expressiva é o haicai de Shiki traduzido por Maurício Arruda Mendonça: "No meio do mato / a flor branca / seu nome desconhecido" (versão muito próxima à de R. H. Blyth: "Among the grasses, / A flower blooms white, / Its name unknown"59).

\subsection{De Bashô a Shiki}

Bashô estabeleceu o haicai como forma literária tradicional e caminho para a iluminação zen-budista, ou satôri. Sua influência é visível em artistas como Yosa Buson (1716-1783), poeta-pintor do Período Tokugawa (“Ante o branco crisântemo / a tesoura hesita / por um momento", tradução: Maurício Arruda Mendonça ${ }^{60}$, que podemos comparar com a de Blyth: "The scissors hesitate / Before the white chrysanthemums, / A moment", in BLYTH, 1981: 246) e Kobayashi Issa (1763-1827), poeta de forte expressão emocional voltado à observação dos insetos, animais, aves e crianças ("A neve está derretendo - A aldeia - está cheia de crianças!”, tradução: Paulo Franchetti ${ }^{61}$ ). A renovação do haicai como gênero literário, porém, é obra de Masaoka Shiki (18671902), autor que "pertence a um outro mundo, o da integração ou confronto do Japão antigo com o Ocidente" (FRANCHETTI: 1990, 28). "Vivendo em uma época em que a influência da recém-descoberta cultura ocidental ameaçava de extinção as formas

\footnotetext{
${ }^{59}$ In MENDONÇA, 1999: 117 e BLYTH, 1981: 256 (primeiro volume).

${ }^{60}$ In MENDONÇA, 1999: 116.

${ }^{61}$ In FRANCHETTI, 1990: 74.
} 
literárias tradicionais", escreve o estudioso brasileiro Paulo Franchetti, Shiki "foi um homem totalmente imbuído de sua missão histórica: preservar e multiplicar o interesse pela poesia japonesa em tercetos de 5-7-5 sílabas e com a imagética tradicional japonesa" (idem). "Shiki é a síntese de um período de transformações radicais no Japão, a chamada Restauração Meiji”, escreve Maurício Arruda Mendonça. "Como um artista moderno japonês, convivem nele a formação de samurai, a influência da literatura chinesa, o racionalismo neoconfucionista, a estética ocidental e um feroz e contundente desejo de revisar os gostos e modelos tradicionais do haicai” (MENDONÇA, 1998: 114115). Ativista cultural e crítico literário, Shiki publicou artigos e poemas em jornais e revistas, contribuindo decisivamente "para manter vivas e em primeiro plano as características que julgava mais específicas da poesia japonesa - expressão direta, objetiva, por meio de imagens claras, sem abstrações ou sentimentalismo" (idem). Foi ele quem criou a palavra haiku, a partir da aglutinação de HAIkai e hokKU, para designar o terceto de 5-7-5 sílabas como um gênero autônomo, e não mais como parte de uma pintura, renga ou diário. Na opinião de Shiki, "haiku era uma forma poética, enquanto renga não tinha estatuto artístico, não era arte. As noções de autoria individual e de autonomia do objeto estético - conflitantes com as que presidiram à criação do renga - levaram-no a rejeitar o poema coletivo" (FRANCHETTI: 1990, 28). A partir de Shiki, o haicai (ou haiku) passa a ser literatura, e não mais uma expressão poética da filosofia zen-budista. Conforme R. H. Blyth, "Shiki revolucionou o haicai. Ele se esforçou em capacitar as pessoas a escrever sem qualquer fundamento espiritual ou religioso muito definido; escrever haicai embora não trilhando o Caminho do Haicai” (in MENDONÇA, 1998: 115). "Shiki tencionava separar os elementos espirituais que faziam do haicai mais uma prática religiosa do que um fazer poético. A afirmação de Shiki era clara: 'haicai é literatura', e portanto, passível de análise crítica e de novas 
abordagens estéticas", escreve Maurício Arruda Mendonça (idem). "Para ele o haicai era concebido pelo indivíduo e, por isso, assumia características particulares. Daí seu desprezo pelo haikai-no-renga, o poema coletivo resultante de encadeamento de haicais, de caráter eminentemente lúdico, modalidade 'destituída de arte', na visão de Shiki (idem)." Quais eram os valores estéticos defendidos por Shiki, nos artigos que publicou em jornais da imprensa diária e na célebre revista Hototogisu (ホトトギス), que ele fundou e editou até o final da vida? Em primeiro lugar, a afirmação do terceto de 5-7-5 sílabas como forma literária autônoma e sem viés religioso; em segundo lugar, o uso do kigo, ou verso com referência à estação do ano, e por fim a observação direta dos fenômenos, com o máximo de objetividade. Maurício Arruda Mendonça observa que desde 1894 Shiki “já demonstrava uma predileção pelo haicaísta Buson, tendo inclusive publicado o volume Haijin Buson (1896), no qual enaltecia as qualidades de verdadeira pintura de seus haicais, sua habilidade em contar uma história em 17 sílabas" (MENDONÇA, 1998: 115). O ano de 1894 também será importante porque registra o encontro de Shiki com o pintor Nakamura Fusetsu (1866-1943), “que o iniciará na sua teoria denominada shasei (写生), a qual privilegiava o retrato do estado natural, a representação verídica não só de paisagens, mas também de situações do cotidiano" (idem). "Descrevendo os objetos com clareza e objetividade, como se estivessem emoldurados na 'tela' de uma janela imaginária”, escreve Maurício Arruda Mendonça, "o ideal de shasei poderia ser levado a um alto grau de refinamento. Pode-se dizer que, baseado na poética de Buson e na teoria do shasei, Shiki chegaria a defender a tese de que o haicai e a pintura são artes idênticas" (idem). Como ilustração a esta ideia, podemos citar os versos de Buson: "Com a luz do relâmpago, / Barulho de pingos -- / Orvalho nos bambus ${ }^{62 "}$ (tradução: Paulo Franchetti). Shiki teve numerosos discípulos,

\footnotetext{
${ }^{62}$ In FRANCHETTI, 1990: 105.
} 
entre os quais se destaca Takahama Kyoshi (1874-1959), que manteve-se fiel ao pensamento de seu mestre. Em 1912, escreveu na revista Hototogisu: "O haicai, como eu o entendo, é uma arte literária clássica. Considerá-lo dessa maneira não é diminuí-lo como se fosse coisa antiquada. Uma arte literária clássica é algo especial, construída sob regras há muito estabelecidas" (in MENDONÇA, 1998: 117). "O poeta que permanece dentro dessa disciplina", continua, "é livre para trabalhar desembaraçadamente como lhe aprouver. Quais são as convenções do haicai? As principais são o interesse pelos tópicos sazonais, a limitação a dezessete sílabas e a linguagem poética" (idem), regras seguidas atualmente por numerosos grupos de poetas que se dedicam ao haicai, no Japão e no mundo ocidental.

\subsection{0 caráter visual da poesia japonesa}

O caminho da caligrafia, ou shodô (書道, “o caminho da escrita”), surgiu na China, durante a dinastia Han (202 a.C. a 220 d.C.), e sempre esteve associado à poesia e à pintura $^{63}$. "É a caligrafia que dá corpo ao poema", escreve Leonardo Fróes, "tendo ela em si, já na feição que os traços assumem, a capacidade de fixar estados de espírito" (in CAPPARELLI, Sérgio, e YUQI, Sun, 2012: 23). "Na mão do poeta”, prossegue o autor, "enquanto ele raciocina em palavras que têm de adaptar-se a uma forma, o pincel vai circular entre relaxamento e tensão, delicadeza e vigor, para constituir seu dizer." Deste modo, "poesia, caligrafia e pintura são a rigor faces da mesma arte, não estando as três

\footnotetext{
63 "No começo do século III a.C., Qin Shi Huang, conhecido como o Primeiro Imperador, reprimiu as revoltas dos Estados em guerra e unificou a China. Ao mesmo tempo, ele organizou e consolidou a escrita e os caracteres chineses que ficou conhecida como a escrita seal ou tensho. Esta escrita era bem balanceada seguindo um rígido conjunto de regras. Ela dá uma impressão de estabilidade e grandeza, sugerindo a solene dignidade da dinastia Qin (221-207 a.C.). (...) Gradualmente, a escrita seal ou tensho foi considerada muito incômoda para o uso diário, e como resultado, foi sendo desenvolvida uma menos complexa, a escrita reisho. Como a maioria dos oficiais começou a usar a escrita reisho, ela acabou por ser refinada e se tornou, para os propósitos práticos, a escrita formal da dinastia Han (206-24 d.C.). Na escrita reisho uma das pinceladas é horizontal, apresentando, frequentemente, uma pequena dobra à direita e formato retangular em sua totalidade. " (SAITO, 2004: 19)
} 
compartimentadas, e às vezes um mesmo artista, caso de Wang Wei, se destaca como mestre em todas $^{64 "}$ (idem). A espontaneidade, a naturalidade, típicas das artes tradicionais inspiradas pelo taoísmo e pelo zen-budismo, estão presentes também na caligrafia. Conforme Viviane Alleton, "na China, o ato de escrever, longe de ser uma ruptura do 'estado de natureza', está ligado ao sentimento da natureza. Para muitos chineses, não há bela paisagem sem uma inscrição na pedra, poema, dístico ou simples caractere" (idem, 94). No tratado clássico chinês Meng Tian bijing, é dito que "deve-se conduzir o pincel até o fim, de uma maneira natural, como o peixe que nada com facilidade na água. Escreve-se aqui com suavidade, ali com força (...), mas sempre com a naturalidade das nuvens, espessas ou leves, que escalam o topo de uma montanha." (idem). Já no livro Gu jin shu ren you lue ping, afirma-se que "os caracteres escritos por Tchong You assemelham-se à fênix que paira no ar ou às gaivotas que sobrevoam a superfície do mar" (idem). Os caracteres caligrafados por Wang Xizhi são comparados, nessa mesma obra, à "vivacidade de dragões impetuosos que saltam em direção ao céu ou de tigres que percorrem as montanhas." (idem). Todas estas definições, embora metafóricas, indicam a ação espontânea de uma arte "que explora a beleza e a simplicidade espontâneas da linha", onde "cada pincelada é desenvolvida pelo movimento de decisão. As pinceladas não são passíveis de correção" (in SAITO, 2004: 29), assim como acontece no haicai (o que nos faz recordar um adágio zen-budista citado pelo poeta norte-americano Allen Ginsberg: "primeira ideia, melhor ideia"). Segundo Gombrich, os artistas chineses buscavam "adquirir uma tal facilidade no

\footnotetext{
${ }^{64}$ Conforme Cecília Noriko Ito Saito, "à luz da Semiótica da Cultura, a polêmica instaurada pela história, que via o shodô ora como escrita, ora como pintura, praticamente desaparece, uma vez que tanto pintura como caligrafia seriam textos da cultura. (...) Metaforicamente, assemelha-se" (o texto) "a uma rede que transmite a imagem de algo que cresce, expande e se desenvolve, onde a inscrição do autor é lúdica. $\mathrm{O}$ texto é plural, não tem centro, nem fechamento e não depende de uma interpretação (...) O semioticista Cesare Segre (1989: 152) diz que a palavra textus firmou-se na língua latina como particípio passado de texere, metáfora do discurso como um tecido que se atualizou não permanecendo apenas como vocabulário.“ (SAITO, 2004: 23).
} 
manejo do pincel e tinta que pudessem registrar a imagem enquanto sua inspiração ainda estava fresca, à maneira de um poeta escrevendo seus versos" (idem, 39).

O Japão importou da China a arte da caligrafia e o alfabeto de ideogramas em meados do século III d. C. e esta aquisição teve reflexos profundos na concepção e estrutura visual de sua tradição poética, apesar das diferenças entre os dois idiomas (conforme Donald Keene: “o gênio da língua japonesa era bem diferente do chinês. Não só sujeito, predicado e objeto eram, até um grau, indistinguíveis, e a pontuação inexistente, mas até o perfil das palavras era borrado". In LEMINSKI, 1983: 33). A caligrafia japonesa, exercida inicialmente pelos sacerdotes budistas, desenvolveu-se no final do Período Asuka (538 a 710 d. C.) e a mais antiga peça escrita em papel é o Hokke Gisho (法華義疏), conjunto de quatro rolos com comentários sobre o Sutra Hokke, datado de 615 d.C. No final do Período Heian (794-1185), conforme Cecília Noriko Ito Saito, "surgiram manuscritos executados em folhas de papel, cortados em forma de leques, que sintetizavam a caligrafia e a pintura" (SAITO, 2004: 15). Ao contrário da arte visual religiosa tradicional, nesses manuscritos "os motivos eram determinados pela iconografia" (idem), libertando-se dos "laços ritualísticos" (idem). Nesse período, os calígrafos já não eram monges-pintores, mas artistas leigos que preferiam retratar cenas mundanas. Desenvolveram-se três estilos básicos de caligrafia: kaisho ou shinsho, "um estilo que apresenta quebras e movimentos duros" (idem, 19), gyosho, "estilo mediano, de letra cursiva, que não se apresenta tão duro quanto o kaisho" (idem) e sosho, "estilo fluido composto por cursos rápidos", que por sua beleza se tornou "o estilo mais popular entre os mestres da caligrafia" (idem). Com o passar do tempo, a arte do shodô passou a fazer parte da vida cotidiana dos japoneses, sendo utilizada na decoração da sala de chá ou no tokonoma (床の間), nicho especial de um 
aposento decorado com uma caligrafia ou pintura e arranjos florais. Os instrumentos utilizados tradicionalmente pelos mestres japoneses de caligrafia são o pincel feito com cerdas de pêlo de coelho ${ }^{65}$ (筆, fudê), a tinta feita à base de carvão em óleo vegetal (墨, sumi, usado na pintura sumiê) e ainda o papel feito com fibra de bambu, palha ou bagaço de bananeira (和紙, washi). Os calígrafos utilizavam ainda uma esteira macia e absorvente, colocada abaixo do papel (下敷き, shitajiki), pequenos pesos em forma de barras, para segurar o papel (文鎮 , bunchin) e o suporte para a tinta (硯, suzuri). A realização da caligrafia é bastante ritualizada, desde a preparação da tinta até a execução do pincel e envolve gestualidade e improvisação. "Existe algo de instância não determinada, não pronta e que se resolve no instante de sua execução”, escreve Cecília Noriko Ito Saito (idem, 102). "Esta é a característica-chave do shodô. Quando um indivíduo pratica o shodô, realiza algo nesse processo, através da ação do seu corpo ${ }^{66 "}$ (idem). A importância da gestualidade na escrita e na caligrafia permite o paralelo, estabelecido por Saito, entre o shodô "e alguns artistas da vanguarda, mais exatamente Jackson Pollock" (idem, 39). Conforme a estudiosa brasileira, em seu livro O shodô, o corpo e os novos processos de significação:

Os novos artistas-investigadores consideravam a pintura, o esboço e o quadro como uma ação, e, como tal, a primeira ação deveria ser a melhor. Nada poderia obstruir a ação de pintar. O que importava era a revelação contida no ato. Traçando um paralelo de similaridade com o artista que trabalha o shodô, a perfeição da pincelada que não permite correção indica a valoração da primeira ação (idem).

Na França, o estilo do expressionismo abstrato ou Action painting, caracterizado por pinceladas espontâneas, borrões e respingos de tinta, compondo superfícies ásperas e

\footnotetext{
65 “Os tipos de pêlos de animais, utilizados nos pinceis, trazem resultados diversos quanto à elasticidade. Alguns absorvem mais tinta, alguns liberam mais, e cabe ao calígrafo decidir qual é aquele apropriado para um trabalho específico. Ao contrário de se usar uma pena, o pincel dos calígrafos reserva mais controle na espessura e no tom dos caracteres. Os artesãos hábeis fabricam seus próprios pinceis, experimentando-os conforme seus efeitos" (idem, 102)

66 Com efeito, segundo Shutaro Mukai, professor da Musashino Art University, os próprios ideogramas "são associados com o sentido do tato ou a sensação física" (in CAMPOS: 2000, 18) e evocam, para o japonês, "a memória dos movimentos musculares envolvidos no ato de escrever" (idem, 19).
} 
assimétricas na tela, foi chamado de tachismo, palavra derivada do termo francês tache, que significa "mancha". Nos Estados Unidos, Jackson Pollock (1912-1956) foi o primeiro artista plástico que se interessou por essa técnica de aplicação de tinta, "e, como na caligrafia chinesa, suas pinturas deveriam ser feitas de uma forma rápida e não-premeditada. Na maioria das vezes, o pintor colocava suas telas no chão, arremessando as tintas sobre ela para descobrir novas configurações" (idem, 40). Conforme Saito, "Pollock desenvolve qualidades rítmicas neste método de respingamento ao acaso. Nesse processo, as mãos do artista não são determinantes, sendo a variedade das formas das linhas, elas próprias, dotadas de uma linguagem individual" (idem, 40). O calígrafo japonês, por seu turno, "interessa-se pelo ritmo da linha e é através dele que a energia é controlada. Na medida em que o trabalho é executado, o ritmo penetra inteiramente nos movimentos do corpo, braço e pincel, tornando-se uma base inconsciente que o capacita a soltar-se livremente" (idem). Não se trata, diz a estudiosa brasileira, de uma "repetição mecânica de pinceladas, mas sim uma peça viva que responde aos impulsos criativos do momento. A linha apresenta fluidez e oferece uma grande diversidade de expressão", comentário que podemos estender tanto a Pollock quanto a Ono no Michikaze (894-966), um dos maiores calígrafos japoneses, que viveu durante o Período Heian. As similaridades entre a caligrafia artística japonesa e o expressionismo abstrato podem ser ampliadas até as experiências poéticas de autores portugueses que investiram na composição visual, como Ana Hatherly e E. M. de Melo e Castro, expoentes do movimento da Poesia Experimental.

Estudamos, no presente capítulo, os gêneros poéticos mais praticados na literatura japonesa entre os séculos VIII e XIX, com ênfase particular em seus aspectos estruturais, referências culturais e a íntima relação entre poesia, caligrafia e pintura, que 
fascinarão os poetas portugueses na segunda metade do século XX. No capítulo seguinte, iremos rastrear o diálogo cultural entre os autores portugueses e a cultura japonesa desde os relatos de viajantes do século XVI até os livros memoráveis de Wenceslau de Moraes, primeiro tradutor do haicai para a língua portuguesa. 


\section{CAPÍTULO II}

\section{A RECEPÇÃO DA POESIA JAPONESA EM PORTUGAL DO SÉCULO XVI ATÉ A RESTAURAÇÃO MEIJI}

\section{1 - A chegada dos portugueses ao Japão}

O diálogo entre os poetas e narradores portugueses e a cultura japonesa começa no século XVI, com os relatos de Fernão Mendes Pinto, Luís Fróis, o padre João Rodrigues e outros autores quinhentistas que visitaram o arquipélago japonês em missão comercial ou evangelizadora. O intercâmbio cultural, comercial e religioso entre Portugal e as ilhas japonesas será interrompido durante o xogunato Tokugawa e retomado apenas na segunda metade do século XIX, após a Restauração Meiji. O presente capítulo estudará as referências ao Japão e à cultura japonesa nos escritos de autores portugueses do período, com destaque para a obra do escritor e diplomata Wenceslau de Moraes, que pesquisou a história, a religião, o folclore, a política, a literatura e as artes tradicionais japonesas e realizou as primeiras traduções de haicais para a língua portuguesa.

A mais remota referência literária ocidental ao Japão encontra-se nas Viagens de Marco Polo (1254-1324), que chamava esse país de Zipagu ${ }^{67}$ (a partir do chinês Jihpên-kuo, "terra do sol nascente"): "Zipagu é uma ilha a levante, a mil e quinhentas milhas em alto mar. A ilha é bem grande, e sua gente é branca, de boas maneiras e formosa; adoram ídolos e não estão sob o domínio de ninguém, senão de si mesmos” (POLO, 1997: 136). O viajante veneziano afirma que "ali se encontra muito ouro, porque o têm em abundância, mas ninguém ali vai e nenhum mercador leva daquele ouro, e por isso o têm em tamanha quantidade" (idem). Conforme escreve o ensaísta português Fidelino de Figueiredo, em texto publicado no volume Torre de Babel, em

\footnotetext{
${ }^{67}$ Em algumas edições do livro de Marco Polo, a palavra é grafada como Cipango ou Cipangu.
} 
1925, a repercussão do livro de Marco Polo em Portugal foi imensa: "O manuscrito dessa tradução latina circulou muito em Portugal, principalmente na época das viagens de descobrimento" (in MORAES, s/d: 19), sendo aceita a tradição, partilhada desde o século $\mathrm{XV}$, que o livro "foi trazido ao reino pelo Infante D. Pedro, o qual andou as sete partidas do mundo e morreu em Alfarrobeira. D. Duarte e D. Manuel II foram seus leitores, como mostra a existência da obra entre os livros de seu uso" (idem). O autor prossegue o comentário afirmando que a obra de Marco Polo, seja no manuscrito latino, seja no texto português impresso, "foi folheado com mão diurna e noturna pelos teóricos dos nossos descobrimentos, pelos historiadores e pelos cartógrafos" (idem).

A descrição feita por Marco Polo em sua narrativa de viagem "deixava o novo país envolto numa névoa de fabulosas riquezas", escreve Armando Martins Janeira, em seu livro O impacto português sobre a civilização japonesa (JANEIRA, 1988: 26), “e assim, quando Cristóvão Colombo descobriu o Haiti, em 1492, estava convencido de que tinha chegado ao misterioso Cipangu de Marco Polo" (idem). Quando o padre João Rodrigues, um século mais tarde, escreveu a sua História da Igreja no Iapam "sentiu-se na necessidade de demonstrar que o Cipangu, de que falava o mercador veneziano, era o país que ele habitava" (idem). O primeiro europeu que usou a palavra Japão, aliás jampon, foi o português Tomé Pires, na Suma oriental, publicada em 1515, que descreve as plantas medicinais que encontrou em suas viagens à Malásia. Em 1572, outro viajante português, que percorreu Macau, Goa e Moçambique - Luís de Camões publicou seu poema épico Os lusíadas. No canto X dessa obra, o poeta descreve os continentes e países conhecidos na geografia portuguesa do século XVI, fazendo breve referencia ao Japão: “... Esta, meio escondida, que responde / De longe à China, donde vem buscar-se, / É Japão, onde nasce a prata fina, / Que ilustrada será co'a Lei divina” (CAMÕES, 1999: 745, estrofe 131, edição crítica de Francisco da Silveira Bueno). A 
passagem, embora sucinta, aponta dois fatos históricos relevantes: o interesse português nas minas de ouro e prata do Japão e o propósito de evangelização das ilhas japonesas, que acontecerá a partir do final do século XVI, com a vinda de comerciantes e missionários europeus. Em 1543, os primeiros portugueses ${ }^{68}$ desembarcam na ilha de Tanegashima, episódio relatado por Fernão Mendes Pinto na Peregrinação e tem início o Período Nanban (palavra derivada de nambanjin, ou "bárbaros do sul", modo como os japoneses referiam-se aos portugueses e espanhóis), durante o qual houve intensa interação comercial, cultural e religiosa entre japoneses e europeus.

O Japão (em japonês: 日本; transl.: Nihon ou Nippon; oficialmente 日本国, Nipponkoku ou Nihon koku), um arquipélago formado por 6.852 ilhas - entre elas as quatro maiores, Honshu (本州), Hokkaido (北海道), Kyushu (九州) e Shikoku (四国), que representam 97\% do território nipônico - era mais povoado do que qualquer país europeu da época, com uma população de 26 milhões de pessoas. A sociedade japonesa, aristocrática e feudal, tinha uma rígida divisão entre classes sociais - mercadores, camponeses, sacerdotes, guerreiros - e uma economia baseada, sobretudo, na agricultura; entre o final do Período Momoyama (1573-1598) e o início do Período Tokugawa (1603-1867), porém, as atividades comerciais conheceram uma fase de rápido desenvolvimento, e com elas prosperam as cidades. O jesuíta português João Rodrigues, que viveu em Kyoto, então capital do império, entre os séculos XVI e XVII,

\footnotetext{
${ }^{68}$ Conforme Armando Martins Janeira, "a data da chegada dos portugueses ao Japão é muito discutida. As principais fontes históricas apontam os anos de 1542 ou 1543. Os testemunhos por esta última data parecem mais ponderados. Em favor dela são António Galvão, no seu Tratado, e a crônica japonesa sobre a história da introdução da espingarda no Japão, Teppo-ki, escrita em 1606 pelo Nampo Bunshi, padre budista da seita zen, de Satsuma, para o senhor de Tanegashima. (...). Fernão Mendes Pinto reclama na Peregrinação a honra de ser o primeiro ocidental a chegar no Japão. Schurhammer e Boxer negam-lhe a prioridade, dizendo que este naquela data é mais provável que estivesse na Birmânia ou no Pegú, embora ambos reconheçam que Mendes Pinto foi ao Japão muito cedo, em 1544. Armando Cortesão, Samuel Purchas e Dorothy Osborne garantem a versão de Mendes Pinto". (JANEIRA, 1988: 27-28)
} 
chama essa localidade de "a nobre e populosa cidade de Miyako" ${ }^{69 "}$ (in COLLCUTT, JANSEN e KUMAKURA, 2008: 108). Rodrigo de Vivero y Velasco calcula a população da capital japonesa em 800 mil pessoas e estima que "cerca de 300 mil ou 400 mil vive nos arredores" (idem). Octavio Paz, em conhecido ensaio sobre a cultura japonesa, refere-se a esse período com estas palavras: "Vive-se na rua e multiplicam-se os teatros, os restaurantes, as casas de prazer, os banhos públicos atendidos por moças, os espetáculos dos lutadores. Uma burguesia próspera e refinada protege e fomenta os prazeres do corpo e do espírito" (PAZ, 1996: 156). As gravuras coloridas em madeira, ou ukiyo-ê (浮世絵, “imagens do mundo flutuante”) surgem nesse período, assim como os romances pornográficos, ou "Livros de primavera", e as peças do teatro de marionetes, ou kabuki (歌舞伎). O mais conhecido pintor japonês dessa era, mestre na técnica das gravuras coloridas, foi Hokusai (1760-1849), que retratou o cotidiano de mercadores, operários, prostitutas, com bastante realismo. Sobre ele escreveu Wenceslau de Moraes no livro Dai Nippon: "Desenhando especialmente para os romances ilustrados em voga, o desenho de Hokusai passava do papel para a gravura, e era destruído" (MORAES, s/d: 91). Por essa razão, "raríssimos são os originais do mestre; e poucos kakemonos seus se conhecem; os que existem, e que hoje valem quantias fabulosas, são uma maravilha de coloração e de verdade" (idem).

A expansão comercial, que sustentou o florescimento cultural e urbano das grandes cidades, estava relacionada com as necessidades militares dos senhores feudais, ou daimyôs (大名 $)^{70}$, uma vez que o Japão vivia um período conturbado, de constantes guerras civis, conhecido como Sengoku (戦国時代), que antecedeu a unificação. “Eram

\footnotetext{
${ }^{69}$ Miyako ou Miaco, nome da cidade de Kyoto no século XVII.

${ }^{70}$ Aluísio Azevedo, vice-cônsul em Yokohama entre 1897 e 1899, escreve a respeito do daymiô em seu livro $O$ Japão, que deixou inacabado e teve publicação póstuma: "puro chefe feudal, com senhorio e
} 
necessários comerciantes que abastecessem os exércitos de armas, cavalos e armaduras; de alimentos, bebidas e roupas para as tropas; que vendessem materiais de construção para levantar fortes e castelos e madeira para embarcações e pontes" (idem, 108-109). Graças ao intenso comércio com Portugal, e depois com a Espanha, Holanda e Inglaterra, os japoneses entraram em contato com os grandes centros comerciais da Europa e da Ásia. "Navios japoneses que tinham licença zarparam para Luzon e para o Sul da Ásia, onde se estabeleceram alguns grupos de comerciantes. O século XVI presenciou também uma crescente efusão de ouro e de prata procedente das novas minas abertas no país" (idem, 109). Toyotomi Hideyoshi, o "senhor da guerra" que liderou o Japão nas últimas décadas do século XVI, "consciente dos benefícios que o comércio podia oferecer, impôs exações aos comerciantes, exerceu um controle direto das minas e efetuou cunhagens de ouro e prata" (idem), além de criar "um sistema monetário uniforme" e investir "na construção em grande escala de castelos e fortificações" (idem). O contato com o mundo ocidental movimentou a economia japonesa, especialmente a partir de 1550.

Conforme Daniela de Carvalho, no artigo Nambanjin: sobre os portugueses no Japão, "desde a chegada dos primeiros portugueses ao Japão que comerciantes portugueses se dirigiam à ilha de Kyushu” (CARVALHO, 2000: 134). No início, prossegue a autora, “o comércio era conduzido por empresas privadas, mas, à medida que aumentavam os lucros, o estado português decidiu intervir e começou a organizar o comércio com o Oriente" (idem). A partir de 1556, um barco por ano dirigia-se ao Japão, e o intercâmbio comercial intensificou-se quando os comerciantes portugueses passaram a ser intermediários entre a China e o Japão (as transações entre os dois países tinham sido proibidas pelos imperadores Ming em 1480, devido à ação de piratas que construir navios e ferir batalhas" (AZEVEDO, 1984: 54). 
espalharam o terror ao longo da costa chinesa. "Nestas circunstâncias", escreve Daniela de Carvalho, "os portugueses depressa perceberam que, servindo de intermediários comerciais entre os dois países, podiam obter grandes lucros”. In: CARVALHO, 2000: 134). O comércio com as ilhas japonesas "tinha como base Macau, que se fez com os ricos lucros deste comércio", escreve Armando Martins Janeira. "Os barcos do comércio entre Macau e o Japão eram os maiores barcos do mundo, atingindo 2.000 toneladas" (JANEIRA, 1988: 144). Kurufune (黒船), ou “navios negros” era como os japoneses chamavam os barcos portugueses que chegavam ao arquipélago nipônico para fazer o comércio. "Não é possível estimar com precisão o volume de negócios", escreve Daniela de Carvalho, "mas não restam dúvidas que esta atividade foi muito lucrativa para os portugueses. Os japoneses importavam sobretudo seda, ouro, veludo, cerâmica e exportavam prata e objetos feitos em lacre" (idem, 135). Segundo Armando Martins Janeira, o Japão também importava "veludo, pólvora e porcelana, que os portugueses traziam da China, e especiarias, que traziam da Índia e do Sudeste asiático. Vinho era trazido de Portugal, e frequentemente dado de presente aos senhores feudais, que muito o apreciavam" (JANEIRA, 1988: 120). A lista de mercadorias que as galeotas portuguesas trouxeram ao Japão em 1637 incluía também “damascos, brocados e cetins de várias denominações e qualidades, veludo, xales, tecidos de algodão, gaze e linho, peles e cabedais, ouro em obra, óculos, porcelanas (...), marfim, campainhas de coral, caixas para tabaco, dois ratos brancos vivos", entre outros itens identificáveis, "no valor total de 2. 141.468 taéis" (idem). Luiz Caldas Lisboa e Mara Rúbia Araki, no livro Namban - O dia em que o Ocidente descobriu o Japão - ressaltam a importância do comércio de armas com os portugueses, que trouxeram a espingarda para o Japão, o que levou à mudança das táticas de guerra dos samurais e facilitou o processo de unificação 
do país, conduzido por Oda Nobunaga. Wenceslau de Moraes comenta que a introdução da espingarda nas ilhas japonesas "marca o início, nas artes de guerra do Japão, de uma época nova. Constitui uma verdadeira revolução nos processos de ataque e defesa" (MORAES, 1993: 42). A nova arma, prossegue o autor, irá "vulgarizar-se por toda a parte, impondo no país inteiro modificações imediatas na construção das fortalezas, na estratégia da guerra etc.” (idem). O impacto da introdução de armas de fogo no Japão foi tão grande que inspirou obras literárias como a Teppo-ki, ou "Crônica da espingarda”, que traz uma curiosa descrição dos portugueses, de acordo com a ótica nipônica:

Estes homens, bárbaros do Sudeste, são comerciantes. Compreendem até certo ponto a distinção entre superior e inferior, mas não sei se existe entre eles um sistema próprio de etiqueta. Bebem um copo sem o oferecerem aos outros; comem com os dedos, e não com pauzinhos como nós. Mostram os seus sentimentos sem nenhum rebuço. Não compreendem o significado dos caracteres escritos. São gente que passa a vida errando de aqui para além, sem morada certa, e trocam as coisas que possuem pelas que não têm, mas no fundo são gente que não faz mal.

(in JANEIRA, 1988: 31)

O retrato satírico dos portugueses está presente em diversos textos literários japoneses do período e também nos famosos biombos namban (南蛮), pintados por mestres das escolas Kano, Tosa e Sumiyoshi, em cidades como Nagasaki e Kyoto. Segundo Armando Martins Janeira, "o tema favorito destas pinturas é a chegada dos portugueses ao Japão. Vêem-se em geral, no primeiro plano, o capitão-mor, levado num andor ou sob uma larga umbrela, seguido de jesuítas, ou frades, que vêm ao seu encontro" (idem, 177). A cena da chegada dos portugueses é conhecida como namban gyoretsu, ou "cortejo dos bárbaros do sul" (idem). Os portugueses foram retratados também em "caixas de laca, bocetas, polvorinhos e outros objetos", em que os missionários e comerciantes lusitanos apareciam com "narizes enormes, largos chapéus e largas calças apertadas nos tornozelos, chamadas 'bombachas"” (idem, 178). O retrato de época nos objetos de arte japoneses produzidos nesse período era tão detalhado que 
os biombos namban são hoje, ao lado das gravuras de Linschoten, "a única fonte para o estudo do vestuário dos portugueses na Ásia nos fins do século XVI e começos do seguinte" (idem). Sobre a rica arte dos biombos japoneses, Sophia de Mello Breyner Andresen escreveu um conhecido poema:

\section{OS BIOMBOS NAMBAN}

Os biombos Namban contam

A história alegre das navegações

Pasmo de povos de repente

Frente a frente

Alvoroço de quem vê

O tão longe tão de pé

Laca e leque

Kimono camélia

Perfeição esmero

E o sabor de tempero

Cerimónias mesuras

Nipónicas finuras

Malícia perante

Narigudas figuras

Inchados calções

Enquanto no alto

Das mastreações

Fazem pinos dão saltos

Os ágeis acrobatas

das navegações

Dançam de alegria

Porque o mundo encontrado

É muito mais belo

Do que o imaginado

(ANDRESEN, 1989: 54-55)

O poema, construído sem medidas métricas, apresenta um interessante contraponto entre referências ocidentais e orientais, usando figuras como a aliteração ("Pasmo de povos"), a metonímia ("Laca e leque / kimono e camélia"), elevada a uma função semiótica de índice, e deliciosas caricaturas verbais, que mostram os portugueses vistos pela sarcástica ótica nipônica ("Narigudas figuras", "Inchados calções"). O elemento teatral-circense, nas linhas finais (“Os ágeis acrobatas / das navegações”) sugere alusão 
às pantomimas dramáticas realizadas nas cortes japonesas, muitas vezes com a presença de comerciantes e missionários lusitanos, em que era encenada, de forma cômica, a chegada dos portugueses ao Japão e os rudes costumes demonstrados pelos "bárbaros do sul”, conforme referido por Fernão Mendes Pinto em sua Peregrinação e comentado por Wenceslau de Moraes:

Pode bem imaginar-se a ironia sarcástica, explodindo em girândolas de riso, daquele nobre dáimio, de sua esposa, de sua filha, de todas as damas da sua corte, ao poisarem os olhares naqueles cinco brutamontes, naqueles tremendíssimos alarves, educados na rude boémia das viagens e no convívio íntimo dos povos menos cultos, atirados ali sobre as esteiras, comendo com as mãos, como os macacos, os finos acepipes, que os japoneses levam à boca entre as pontas de duas varinhas de marfim!... (MORAES, 1993: 72).

O Período Namban foi um rico momento de intercâmbio artístico, em que os japoneses assimilaram diversas técnicas europeias, sobretudo na pintura. "A influência da pintura ocidental na pintura mural (shohekiga), afirma Tamon Miki, "não deve ser desprezada" (idem). Kano Sanraku (1559-1635), por exemplo, utilizou a perspectiva em suas obras. Armando Martins Janeira observa que na escola de pintura de Kano Eitoku há influência evidente da pintura a óleo ocidental, "nos mosaicos coloridos de tons escuros obtidos pela aplicação e contraste de pigmentos claros”, embora, de modo geral, a arte japonesa tenha evitado a recepção da estética ocidental. Em meados do século XVIII, "a pintura holandesa exerceu grande influência", escreve Armando Martins Janeira, "sobretudo no emprego da perspectiva, da divisão da luz e da sombra, sobre a escola do Ukyioe, escola que preferia as figuras e assuntos populares, os temas dos teatros, dos artífices, dos bairros do prazer das grandes cidades" (idem, 179). O autor comenta ainda que "o estímulo da pintura europeia ia fazendo um número crescente de pintores japoneses, que procuravam a síntese entre as técnicas e os valores europeus e os tradicionais" (idem). A alternância criativa entre "tradição e estímulos e influências ocidentais", conclui, "foi-se alargando e tomando um lugar cada vez mais importante na evolução da arte japonesa”, sobretudo a partir da Restauração Meiji, na segunda metade 
do século XIX, quando o Japão conhecerá um novo momento de abertura para o diálogo artístico e cultural com o Ocidente.

\subsection{0 início da evangelização}

O intercâmbio comercial e cultural com os portugueses abriu as portas do Japão para a atividade missionária, levada a cabo pela Companhia de Jesus. Conforme William Johnston, professor da Universidade Sophia, de Tóquio, "o cristianismo foi levado para o Japão pelo basco Francisco Xavier, que desembarcou em Kagoshima em 1549 na companhia de dois outros jesuítas e um intérprete japonês” (in ENDO, 2011, 12). Xavier, na qualidade de emissário do vice-rei da Índia, encontrou-se com o daimyô Ouochi Yashita e ofereceu-lhe diversos presentes trazidos de Portugal - relógios, instrumentos musicais, vinho, entre outras coisas - e solicitou permissão para pregar a doutrina cristã. "Apesar da oposição dos monges budistas", escreve Daniela de Carvalho, "foi-lhe concedida a permissão e o próprio senhor feudal se converteu ao cristianismo" (CARVALHO, 2000: 133). Como o Japão encontrava-se numa fase de intensa guerra civil - o Período Sengoku - que dificultava o livre trânsito pelo país, os "missionários exerceram as suas atividades sobretudo na ilha de Kyushu, ao sul do país" (idem). Os navegadores portugueses fundaram ali, na segunda metade do século XVI, a cidade de Nagasaki, que se tornou um importante pólo de intercâmbio comercial e de propagação do cristianismo. A cidade foi cedida à Igreja Católica pelo daimyô Omura Sumitada e a partir de 1571 os barcos portugueses dirigiam-se para esta cidade, considerada por eles "o melhor porto do mundo". Conforme escreve Daniela de Carvalho, "ao rei de Portugal competia pagar as despesas de manutenção em Nagasaki, como protetor das missões no Japão" (CARVALHO, 2000: 136), embora, como ressalta a autora, "esses pagamentos raramente se efetuavam e a Igreja dependia exclusivamente do negócio dos barcos portugueses" (idem). Em 1580, Omura Sumitada assinou um 
contrato concedendo Nagasaki à Sociedade de Jesus. Sete anos depois, Hideyoshi anexou a cidade, que continuou como centro da Igreja no Japão até 1614, tornando-se o refúgio para os japoneses convertidos ao cristianismo, quando estes passaram a ser perseguidos pelo governo japonês. "Com a expulsão dos portugueses e outros europeus, o Japão fechou as portas ao resto do mundo" (idem, 135), escreve Daniela de Carvalho, e a cidadela dos cristãos japoneses passou a ser interditada a comerciantes e missionários portugueses. "Apenas os chineses e os holandeses foram autorizados a permanecer no pequeno porto artificial de Deshima, em Nagasaki”, prossegue a autora, "com as suas atividades circunscritas ao comércio" (idem), encerrando-se um capítulo das relações históricas entre Japão e Portugal.

O diálogo entre os missionários cristãos e as autoridades militares e religiosas japonesas foi conflituoso desde o início. "Os comerciantes eram de fato bem recebidos, mas o mesmo não se passava com os missionários" (idem, 134), escreve Daniela de Carvalho. Os japoneses tinham interesse especialmente no comércio com Portugal, que facilitava a importação de artigos chineses e novidades européias para as casas aristocráticas, o que por si só não significava receptividade à conversão ao catolicismo. "Compreendendo isto", prossegue a autora, "os missionários resolveram explorar o interesse pelo comércio para evangelizar os japoneses" (idem). Deste modo, “comerciantes e missionários completavam-se nas suas atividades" (idem). No início, os jesuítas tentaram se adaptar aos costumes japoneses, adotando suas normas de etiqueta, vestuário, o estilo de suas casas e mobiliário, participavam da cerimônia do chá ${ }^{71}$.

\footnotetext{
71 "Embora os jesuítas tivessem geralmente uma certa preocupação em respeitar as diferenças culturais e adotar os costumes nativos, nem todos os missionários partilhavam essa preocupação. Alguns missionários defendiam posições eurocêntricas e censuravam os costumes japoneses. O padre português Francisco Cabral é disto um exemplo. Considerava os japoneses uma raça bárbara, não admitia que os jesuítas japoneses interviessem na educação dos padres japoneses e não permitia que os padres mais jovens aprendessem japonês, pois considerava ser uma língua demasiado árdua para europeus. Condenava a maneira de viver dos japoneses, as suas maneiras e também o fato de não comerem carne. Este padre foi substituído por um outro que defendia a ideia de que os missionários deviam seguir os costumes japoneses, exceto no que dizia respeito à maneira de vestir”. (CARVALHO, 2000: 136 )
} 
Armando Martins Janeira escreve que "os jesuítas adotaram o mesmo costume, ainda hoje praticado em todos os templos xintoístas, de oferecer aos deuses danças em sinal de devoção, introduzindo na procissão do Corpo de Deus, em Nagasaki, em 1605, danças japonesas e europeias diante do Santíssimo Sacramento” (JANEIRA, 1988: 151). A palavra Deus foi traduzida inicialmente por Xavier como Dainichi, "que é a designação do Buda Vairocana", escreve Armando Martins Janeira. "Esta palavra é já uma adaptação ao budismo duma palavra xintoísta, pois significa 'Grande Sol'” (idem, 147). "Quando Xavier se apercebeu disto", prossegue o autor, "exortou, nas suas pregações, os japoneses a que não acreditassem em Dainichi, que era uma invenção do demônio" (idem). Os jesuítas não aceitavam o culto aos antepassados, prática religiosa tradicional ainda hoje muito popular entre os japoneses, e condenavam a adoração de ídolos. Apesar de todas as dificuldades encontradas pelos missionários no trabalho de evangelização, incluindo a oposição dos sacerdotes budistas e xintoístas - que levaram o missionário Luís Fróis a comparar o trabalho de evangelização às adversidades que um muçulmano teria de enfrentar se tentasse construir uma mesquita em Lisboa - Xavier conseguiu converter centenas de japoneses, partindo pouco depois para a China, “cuja conversão lhe parecia indispensável prelúdio à do Japão” (ENDO, 2011, 12). O verdadeiro arquiteto da evangelização nas ilhas japonesas, segundo William Johnston, foi o italiano Alessandro Valignano (1539-1606) ${ }^{72}$, “que combinava o entusiasmo de Xavier com uma presciência e tenacidade extraordinárias" (idem).

\footnotetext{
72 Conforme Armando Martins Janeira, o missionário "fez três visitas ao Japão: a primeira de 1579 a 1582, em que compôs o Sumario de las cosas de Japón (1583), a segunda de 1590 a 1592, em que compôs as Adiciones al sumario (1592), e a terceira de 1598 a 1603, durante a qual escreveu a Apologia de la Compañia de Jesus y de la China (1598) e Princípio y progreso de la religión cristiana en Japón (1601-1603). (...) Valignano nasceu em Nápoles. Falava três línguas, espanhol, italiano e português, mas preferia a castelhana, que era a mais conhecida dos amanuenses que com ele trabalhavam. Escreve no entanto em português os Advertimentos e avisos dos costumes e catangues do Japão e a segunda parte da História da Companhia das Índias Orientais, cuja primeira parte é redigida em espanhol. O seu livro mais importante é o Sumario de las cosas del Japón" (JANEIRA, 1988: 92).
} 
Quando o missionário italiano realizou a sua primeira visita ao Japão, em 1579, “já havia uma florescente comunidade de 150 mil cristãos, cujas magníficas qualidades e profunda fé inspiraram em Valigmano a visão de um arquipélago inteiramente cristão no norte da Ásia" (idem). Seminários, colégios, hospitais e uma noviciaria foram construídos pela missão católica, que em pouco tempo obtém prestígio na própria corte. "Luís Fróis consegue construir uma igreja numa mistura de estilo japonês e europeu em Quioto", escreve Daniela de Carvalho, "e o número de japoneses a converter-se ao cristianismo foi aumentando" (CARVALHO, 2000: 136) Por volta de 1580, escreve a autora, "havia 150.000 cristãos e esse número duplicou no início do século XVII" (idem). Em 1590, prossegue, "havia 350.000 cristãos numa população nacional de 27.000.000" (idem). O crescimento do intercâmbio comercial, cultural e religioso entre o Japão e Portugal teve entre suas conseqüências o envio de embaixadores japoneses a países europeus. Conforme Armando Martins Janeira, "a embaixada partiu de Nagasaki em 20 de fevereiro de 1582, no barco do capitão Inácio de Lima” (JANEIRA, 1988: 107). "Durante o longo tempo das esperas e da viagem, os dois jovens japoneses estudavam latim, canto, música, japonês e português. Em 10 de agosto de 1584 chegaram a Lisboa" (idem). Da capital portuguesa os emissários japoneses rumaram para Toledo e Madri, na Espanha de Felipe II, e de lá para o Vaticano, onde "os embaixadores tiveram ocasião de assistir à entronização de Sixto V, em 15 de abril, quinze dias depois da morte de Gregório XIII" (idem, 109). No regresso à capital japonesa, os emissários imperiais percorreram "várias cidades da Itália (...). Voltaram por Madri, Évora, Lisboa, Batalha, Alcobaça. Na visita a Coimbra os jovens embaixadores gastaram vinte dias, tendo assistido às festas do Natal” (idem). No dia $1^{\circ}$. de janeiro, continua o autor, os jovens embaixadores assistiram a um sermão na capela da Companhia de Jesus, que foi "traduzido em latim, hebraico, francês, italiano, inglês e 
japonês. (...) Foi o primeiro sermão em japonês dito em Portugal, fato que até hoje não foi provavelmente repetido" (idem). A missão diplomática partiu de Lisboa para o Japão em 8 de abril de 1586 e coroou um processo histórico de abertura ao Ocidente que logo seria interrompido no século XVII, durante o Período Tokugawa, com a expulsão dos missionários e a restrição do intercâmbio com os europeus, que duraria até a Restauração Meiji, no final do século XIX.

\subsection{Relatos dos missionários portugueses sobre o Japão}

Conforme William Johnston, as cartas e registros dos missionários católicos são a principal fonte de informação que temos hoje sobre a sociedade japonesa no período de 1570 a 1614, uma vez que há poucos relatos japoneses sobre esse tempo histórico. Entre os livros escritos pelos jesuítas, destacam-se a História do Japão e o Tratado em que se contém muito susinta e abreviadamente algumas contradições e diferenças de costumes entre a gente da Europa e esta província do Japão, de Luís Fróis (1532-1597), autor também de vasta correspondência, em que descreve, por exemplo, a beleza das casas japonesas e a habilidade dos carpinteiros:

São tão primos os carpinteiros do Japão em suas obras que com fazerem casas mais nobres, e grandes, as fazem de tal maneira todas, que se podem quando querem as desconjuntar em pedaços e levalas de uma parte para outra, como muitas vezes fazem, e para isso costumam lavrar primeiro a madeira toda, e depois em três, ou quatro dias a adjuntão e alevantão, fazendo de improviso hua Casa em hum lugar razo que parece impossível fazer nem com espaço de hum anno.

(in JANEIRA, 1988: 93)

Em outra carta, datada de 27 de abril de 1565, assim descreve um jardim japonês:

... te no meo do jardim, hua alagoa de vinte passos de comprimeto, de agoa singolar, que trouxe a poder de dinheiro, dali a duas, ou tres legoas, e entralhe dentro por hum rochedo de penedia, e trabalhando a mão, que parece obra da mesma natureza. No meo desta lagoa há muitas maneiras de ilhas, e ilheosinhos, que se passam de huas as outras com pontes muitos frescas de pao, e de pedra, e tudo isto fica de baixo de mui frescas arvores, e sem nenhua duvida, que disto se não pode escrever a terça parte do que he.

(idem) 
Na sua História de Japam descreve um castelo:

Tem dentro grande número de cazas mui fermosas, e ricas, porque estão todas cozidas em ouro, tão limpas e bem feitas que parece não pode chegar mais adiante a humana limpeza; e no meio está hua maneira de torres a que elles chamam Tenxu, que tem outra figura mui mais nobre, e soberba que as nossas torres, a qual é de sete sobrados todos por dentro, e por fora feitos de estupenda, e maravilhosa arquitectura, porque por dentro são tudo figuras de ouro, e de diversas cores, que estão pelas paredes mui ricamente pintadas, e por defora está cada sobrado destes pintado de várias cores hus de branco com suas janelas de charão, ou verniz preto como em Japão se uza, que parecem em estremo fermzoas, outros de vermelho, outros de azul, e o que está em cima de todos, e assim este tenxu, como todas as mais cazas, são cubertas de telha as mais fortes e fermozas que quantas sabemos em Europa, que parecem de cor azul, e as dianteiras tem todas huas cabeças redondas douradas e os telhados tem huas soberbas carancas com mui nobre e artificiosa figura, de maneira que fica toda hua mui arrogante, aprimorada e lustroza obra.

(idem, 94-95)

Luís Fróis é considerado o escritor quinhentista que mais escreveu sobre o Japão, principalmente em sua vasta correspondência, em que narra os eventos da guerra civil e os êxitos da atividade missionária. Em 1569, tornou-se amigo de Oda Nobunaga (15341582), "senhor da guerra" que desencadeou o processo de unificação do Japão, com quem estabeleceu fecundo convívio. Outro autor quinhentista que se dedicou a escrever sobre a cultura japonesa foi o já referido padre João Rodrigues, autor do Vocabulário da lingoa de Iapam (1603), chamado de Nippo Jiten entre os japoneses, publicado em Nagasaki, que foi o primeiro dicionário Japonês-Português, com 32 mil verbetes, elaborado para ajudar os missionários no estudo do idioma ${ }^{73}$. Em 1604, João Rodrigues escreveu o volume intitulado Arte da lingoa de Iapam, possivelmente a primeira fonte de informação sobre a poesia japonesa divulgada em Portugal. O jesuíta escreve que

Ha hua sorte de versos a modo de Renga que se chama: Faicai, de estillo baixo \& o verso he de palavras ordinarias, \& facetas a modo de verso macarronico, $\&$ deste modo de Renga, posto que nam tem tantos preceitos como a verdadeira, o numero de

\footnotetext{
${ }^{73}$ Armando Martins Janeira comenta que "os portugueses andaram por todo o Japão, desde Tanegashima, ao sul, até Hokkaido, ao norte, e deixaram ali uma obra notável cujo valor permanece. Foram eles que escreveram as primeiras gramáticas e os primeiros dicionários da língua japonesa, que ainda hoje são reeditados de quando em quando e considerados de valiosa consulta pelos eruditos japoneses, a primeira história do Japão e os primeiros estudos sociológicos e de análise dos costumes nipônicos em língua ocidental. Algumas destas obras estão traduzidas em japonês, alemão, espanhol, francês e inglês, embora nunca hajam sido publicadas em Portugal." (idem)
} 
versos pode ser o mesmo. E pode começar pello segundo verso de sete sete, que se chama Tçuquecu, \& continuar com cinco sete cinco (in FRANCHETTI, 1990: 37).

A referência do religioso português, embora lacônica, indica o conhecimento dos gêneros poéticos e das medidas métricas praticadas nas ilhas japonesas, sem isentar-se de juízo de valor (estillo baixo, palavras ordinárias, nam tem tantos preceitos como a verdadeira). João Rodrigues é autor também da História da Igreja no Japão, em que faz observações sobre a vida cotidiana japonesa, a cerimônia do chá, o budismo e o xogunato. Conforme escreve Armando Martins Janeira, esta iniciativa foi acompanhada por outra, não menos ambiciosa, de tradução para o japonês de vários livros religiosos, como Imitatio Christi, de Tomás Kempis, e "de obras de literatura clássica europeia, como as Fábulas de Esopo, excertos de Homero, Platão, Aristóteles, César, Sêneca, Cícero e outros autores gregos e latinos" (JANEIRA, 1988: 159). Prossegue o autor:

Estas e outras obras de que se conservam muitos raros exemplares, hoje valiosíssimos, demonstram o alto nível intelectual dos homens a quem fora confiada a cristianização do Japão. A maior parte dos missionários enviados para o Extremo Oriente passou por um período de adaptação e treino em Goa, cujo bispado, constituído em 1534, estendia a sua autoridade a todo o Extremo Oriente. Os missionários enviados ao Japão e à China eram obrigados àquele estágio. Ricci completou a sua educação em Coimbra e em Goa. Para todos os missionários Portugal, como diz Panikkar, "era o seu segundo país, o seu lar espiritual”.

(JANEIRA, 1988: 160)

João Rodrigues, que falava e escrevia perfeitamente o idioma japonês, deixou-se encantar pela arquitetura, paisagismo, vestuário, ciências e artes visuais do arquipélago nipônico, escrevendo um curioso relato sobre a então capital imperial, Miaco (Kyoto):

He a Cidade de Miyaco limpissima com ruas muy largas, em todas há agoas de fontes excelentes, e ribeiros que correm pelo meyo dellas...

A gente de Miyaco, e morador he muy branda de condição e muito cortez e grande agasalhadora; e muy bem trajada e dicioza e muy dada em continuas recreaçoens, e folguedos, e passatempos como he ir ao campo com banquetes, a ver comedias, representaçoens e entremezes e outros vários cantos que tem a seu modo; he gente de muita romagem e devação aos templos, e de ordinário há tanta frequiência de homens e molheres que a elles vão a orar, e ouvir pregações que parece um jubileo. A lingoa he a melhor e mais polida de todo o reyno, por estar ali a Corte e os Cughes (nobres) em que isto se conserva; as sahídas desta cidade, por qualquer parte são as mais lindas e agradáveis de frescura e campinas que há em todo o Japão. 
No contorno da Cidade ha lugares de bosques e arvoredos de muita recreação onde todos os dias ha concurço dos da Cidade a se recrearem com banquetes, estendendo certo modo de tendas com que ficam resguardados huns dos outros. São os da cidade muy dados a poezia, que esta nação tem muy excellente e artificiosa a seu modo.

(idem, 98-99)

João Rodrigues seria expulso do Japão em 1610, como consequência de um incidente em Macau com o navio português Madre de Deus, em que foram mortos marinheiros japoneses. Este episódio faz parte de uma série de conflitos que levariam à expulsão de todos os missionários e encerrariam o "século cristão" na Terra do Sol Nascente.

\subsection{A expulsão dos missionários no Período Tokugawa}

Conforme William Johnston, a ruptura foi antecedida, em 1587 pela decisão do “senhor da guerra" Toyotomi Hideyoshi ((1537-1598), sob efeito do álcool, de ordenar que todos os missionários deixassem o país. "Decidi”, lia-se em sua mensagem, “que os padres não devem permanecer em solo japonês. Portanto, ordeno que, tendo eles resolvido seus assuntos aqui num prazo de vinte dias, retornem para sua terra" (in ENDO, Shusaku. 2011, 14). “A fúria de Hideyoshi”, escreve Johnson, "logo se abateu; a maioria dos missionários não deixou o país; e o decreto de expulsão virou letra morta" (idem) $)^{74}$. A comunidade cristã no arquipélago japonês, como anotou C. R. Boxer, não parava de crescer, e quatro anos após a mensagem de Hideyoshi ela já somava 200 mil almas. Em 1597, o "senhor da guerra" tem novo acesso de fúria, ao ser informado por um piloto de um navio espanhol de que os missionários "abriam caminho para as forças armadas do rei” (idem, 14-15). Hideyoshi mandou crucificar, então, 26 missionários,

\footnotetext{
74 “Já em 1587, antes da chegada de outros europeus, Hideyoshi tinha decretado a expulsão dos cristãos e, em 1597, mandou enforcar nove missionários portugueses e dezessete cristãos japoneses (REISCHAUER, 1981: 88)." No entanto, "considerações de caráter econômico levaram Hideyoshi a reconsiderar a decisão. Chamou Valignano e disse-lhe que estava disposto a permitir a presença de comerciantes, mas não a dos missionários. Como lhe foi dito que isso não seria possível e que, se a presença dos missionários não fosse autorizada, os barcos portugueses não aportariam mais no Japão, Hideyoshi abandonou a ideia de expulsar os cristãos". (CARVALHO, 2000: 138)
} 
europeus e japoneses, numa fria manhã de fevereiro, episódio retratado numa pintura exposta no Museu do Oriente, em Lisboa, e também na decoração de inúmeros templos franciscanos ${ }^{75}$, como a Igreja da Ordem Terceira de São Francisco de Assis, em Recife, construção do século XVIII conhecida por sua cúpula dourada. Broering assim relata o episódio, em seu livro Os 26 mártires do Japão: "Foram crucificados do modo seguinte: não foram pregado na cruz, mas amarrados pelos braços e pernas. Foram presos à cruz nos pés, nas mãos e no pescoço por argolas de ferro. No meio da cruz havia uma espécie de assento que ajudava a evitar a sufocação” (BROERING, 1983: 15-16).

"A obra missionária, porém, continuou de alguma maneira", escreve Johnson, no texto de apresentação do romance $O$ silêncio, de Shusaku Endo, que aborda esse período histórico (idem, 15). “Os jesuítas viviam apreensivos, mas ainda desfrutavam as boas graças da corte regencial; e foi apenas no governo de Ieyasu - sucessor de Hideyoshi e primeiro dos xóguns Tokugawa - que a sentença de morte da missão católica se tornou irrevogável” (idem). O pretexto para a decisão, novamente, foi o boato - desta vez apresentado pelo piloto inglês Will Adams - de que a presença de missionários católicos no país estava relacionada a interesses políticos da União Ibérica.

Em 1614, o xogum Ieyasu Tokugawa promulga um édito de expulsão, declarando que "o bando dos kirishitan veio para o Japão (...) ansiando por disseminar uma lei pérfida, destruir a verdadeira doutrina e apossar-se do país. Esse é o germe de um grande desastre e precisa ser esmagado" (idem, 16). Segundo William Johnston, este foi “o golpe de morte. Veio numa época em que havia uns 300 mil cristãos no Japão (cuja população total era de 20 milhões de pessoas), mais os colégios, seminários e hospitais e o crescente clero nativo" (idem). Apesar da repressão, a obra missionária continuou de forma clandestina, “até que, sob os sucessores de Ieyasu, a caça aos fiéis e sacerdotes

\footnotetext{
${ }^{75}$ Na cidade de São Paulo, o episódio foi retratado na Igreja de São Francisco de Assis situada no bairro de Vila Clementino.
} 
cristãos se tornou tão sistematicamente cruel que varreu todo e qualquer vestígio visível do cristianismo" (idem). Segundo o inglês Richard Cocks, a forma usual de execução era a fogueira, e ele declara ter visto "55 pessoas de todas as idades e ambos os sexos serem queimadas vivas no leito seco do rio Kamo, em Kyoto (outubro de 1619), e entre elas havia criancinhas de cinco ou seis anos nos braços das mães" (idem). A perseguição aos japoneses convertidos ao catolicismo ficou conhecida como sakoku e o número de mártires, apenas entre 1614 e 1640, seria de cinco a seis mil mortos, segundo Johnston. O último e decisivo episódio do combate à cristandade foi o levante dos camponeses de Shimabara, em 1637, contra o aumento dos impostos para a edificação de um novo castelo pelo o clã de Matsukura. Conforme escreve Johnston, "essa rebelião (...) transformou-se depois em manifestação da fé cristã, e os insurgentes carregavam estandartes em que se lia 'Louvado seja o Santíssimo Sacramento' e bradavam os nomes de Jesus e Maria" (idem, 18-19). A tragédia era inevitável: “O levante foi sufocado com implacável crueldade, e o xogunato Tokugawa, convencido de que tal rebelião só fora possível com ajuda de fora, resolveu de uma vez por todas cortar os vínculos com Portugal e cerrar o Japão para o resto do mundo" (idem), mantendo apenas vínculos comerciais com os chineses e holandeses no porto artificial de Deshima, em Nagasaki. A essa altura, a contribuição cultural portuguesa nas ilhas nipônicas já era imensa - sendo suficiente citarmos a introdução da tipografia e da imprensa, em 1591, o início dos estudos de história e filologia japonesas, graças ao trabalho de gramáticos e dicionaristas como os padres Duarte Silva e João Rodrigues, bem como a incorporação de palavras portuguesas ao idioma japonês, como assinala Daniela de Carvalho em seu artigo Nambanjin: sobre os portugueses no Japão:

Em todos os livros são referidas palavras portuguesas que entraram no vocabulário japonês como Bisuketto (biscoito); kompeitou (confeitos, doces); shabon, muitas vezes dizem shabon dama (bola de sabão), kasutera (castela, bolo tipo pão de ló), tabako (tabaco), botan (botão), pan (pão), koppu (copo), karuta (carta). Num dos livros 
também se faz referência às palavras japonesas introduzidas na língua portuguesa como katana, biombo (byobu) (CARVALHO, 2000: 142).

A decisão de fechar as fronteiras e suspender o intercâmbio comercial e cultural com outros países não era novidade na história japonesa. Conforme escreve Collcutt, "na história das relações internacionais do Japão, alternaram-se os períodos de relativa abertura e ativos contatos com o mundo externo, com outros de relativo isolamento" (COLLCUTT, JANSEN e KUMAKURA, 2008: 110). No Período Tokugawa, que se estendeu por 264 anos, o Japão se manteve em paz com os vizinhos e sem as disputas de poder entre os clãs que caracterizou os períodos anteriores. "O xogunato Tokugawa foi um estado feudal centralizado e autoritário. Somente no final do período se começou a experimentar uma relativa descentralização como conseqüência da debilitação do poder central (...) e da maior autonomia de alguns dos daimyôs mais influentes" (idem). Conforme Luiz Dantas, o xogum Ieyasu Tokugawa "estabeleceu (...) as bases dessa sociedade através de um certo número de decretos" (in FRANCHETTI, 1990: 212). Em 1615, por exemplo, foram lidas, numa assembléia de daimyôs, as Buke-Shohatto ("regras das casas militares"), que prescreviam normas de conduta para civis e militares, incluindo normas quanto à alimentação e vestuário dos camponeses, regras para o casamento, interdição do consumo de álcool e dos atos licenciosos, entre outros itens. Segundo Luiz Dantas,

é clara no texto a valorização das virtudes militares, obediência e sacrifício, bem como gosto pronunciado pela austeridade. Vida frugal, vestimentas despojadas, moderação nos prazeres; essas aspirações revelam a vontade de impor um ideal patriarcal de existência (idem, 214).

As leis decretadas pelo xogum Tokugawa não se limitavam a "criar os alicerces de um Estado autoritário, mas chegavam até a codificar o estilo de vida, ao mesmo tempo que impossibilitavam qualquer mudança, o crime supremo do regime" (idem). A vida intelectual japonesa nesse período conheceu o estudo intenso da filosofia de Confúcio, que enfatiza o culto aos antepassados, a piedade filial, a obediência aos superiores e a 
lealdade ao imperador, ao mesmo tempo em que valorizava as artes tradicionais inspiradas pelo zen-budismo, como a caligrafia, os arranjos florais e a cerimônia do chá. Somente em Edo (Tóquio), a nova capital do império, havia 800 instrutores de caligrafia. Conforme escreve Collcutt, nesse período "foram publicados inúmeros livros ilustrados mediante a técnica da gravura em madeira devido à grande demanda gerada por uma população urbana cada vez mais instruída" (COLLCUTT, JANSEN e KUMAKURA, 2008: 157). No início do século XIX, o Japão "se converteria pouco a pouco em uma sociedade mais instruída, móvel, fluida e ávida por diversão e entretenimento" (idem). "Além das escolas han, onde se educavam os jovens samurais dos domínios, escolas privadas e escolas de um único cômodo ofereciam instruções básicas aos filhos de aldeões e camponeses" (idem). Ronald Dure estima que, no final do Período Tokugawa, “43\% dos homens e 10\% das mulheres haviam recebido algum tipo de educação escolar. Seja qual for a porcentagem exata, está claro que (...) já estavam assentadas as bases da alfabetização, educação e cultura modernas vindouras" (idem). Wenceslau de Moraes observa que a educação japonesa, inicialmente, era ministrada pelos monges budistas nos mosteiros, que "ensinavam o povo sem distinção de classes, instruindo-o na sua doutrina religiosa, e também no conhecimento dos clássicos chineses, da história, das leis, das matemáticas, da literatura nacional" (MORAES, 1926: 241-245), embora "as mulheres, em especial, eram sistematicamente postas de parte em assuntos de cultura”. (idem). Com o advento da restauração imperial em 1868, prossegue Moraes, “o Japão instituiu realmente um verdadeiro sistema educativo, abolindo distinções, nivelando classes, estendendo a todos os filhos do Império o benefício da cultura" (idem). Com a reforma do ensino, "as crianças japonesas, sem distinção de sexos, entram para a escola elementar ordinária, que é obrigatória e quase gratuita, aos oito anos de idade, ou um pouco antes" (idem). O 
escritor português ressalta a laicidade do ensino nas escolas japonesas: “Apresso-me em dizer que a matéria de religião, tanto na escola elementar como nas aulas superiores que se lhe segue, é absolutamente excluída do ensino em todos os estabelecimentos do governo" (idem), seguindo cada um "a religião que seus pais lhe incutem no seio da família, sem disso dar contas a ninguém" (idem). Wenceslau de Moraes observa também que "não há iletrados no Japão, a não ser alguns indivíduos maduros já em anos, que escaparam aos preceitos educativos que a restauração veio implantar, no ano de 1868" (idem). Nas cidades e aldeias japonesas, conclui, "as escolas elementares espalham-se profusamente, enxameiam, para que haja lugar para toda a gente." (idem).

Esta é, em linhas gerais, a sociedade japonesa que seria redescoberta pelos europeus quando o intercâmbio artístico, econômico e cultural com o Ocidente foi retomado, a partir de 1853, após ameaças de bombardeio da costa japonesa pela esquadra norteamericana do comodoro Perry ${ }^{76}$, que impôs, manu militari, o fim do isolamento nipônico.

\footnotetext{
${ }^{76}$ Comentário de Luiz Dantas: "Matthew Calbraith Perry (1794-1858), o primeiro ocidental a penetrar no Japão com uma frota naval moderna. O comodoro Perry era um oficial antigo e eminente da marinha americana. Aceitou, sem hesitar, o comando do Pacífico, pois não queria suportar o tratamento reservado pelas autoridades japonesas a qualquer tentativa de aproximação por parte dos países ocidentais. Exigiu do governo que forças militares proporcionais à sua posição fossem postas às suas ordens. Foi em 8 de julho de 1853 que sua frota, composta de quatro navios, dois a vapor, dois a vela, lançou âncora na enseada de Uraga. Essa força recebera ordens do presidente Billmore de não tolerar humilhações de nenhum tipo, estar pronta para a ação, e só receber funcionários de categoria elevada para serem ouvidos pelo comodoro. Além disso, trariam uma carta pessoal do presidente americano, na qual explicava que Perry buscava somente a amizade dos japoneses, a possibilidade de reabastecer-se de carvão, garantias para os marujos americanos naufragados perto das costas japonesas e permissão de comerciar. Na capital do shogun, as autoridades decidiram receber a embaixada americana, o que foi feito em 14 de julho, com toda a solenidade. A carta do presidente americano, além dos pedidos já mencionados, continha ameaças apenas encobertas, no caso em que as solicitações não fossem satisfeitas. Com efeito, declarava que o comodoro Perry viria novamente no ano seguinte buscar a resposta com uma esquadra 'mais poderosa'. Foi o caso, pois o comodoro Perry voltou ao Japão em 12 de fevereiro de 1854, bem mais cedo que previsto, porque o oficial americano temia que outros concorrentes ocidentais aproveitassem o sucesso da sua missão para entrarem em contato também com o Japão. (...) A segunda esquadra do comodoro Perry era com efeito mais poderosa, nove navios ao todo. Não representava somente ameaças, todavia, porque os americanos tomaram o cuidado de trazer numerosos presentes - armas, munições, livros, bebidas, batatas, e um trem de verdade em tamanho reduzido, que teve enorme sucesso. O shogun devolveu a seu turno o gesto amistoso, oferecendo os presentes tradicionais japoneses, o sakê e o peixe seco - julgados insuficientes pelos americanos - e quatro cachorros. Entretanto, o essencial foi a assinatura de um tratado de comércio em 31 de março de 1854, prevendo intercâmbios e a abertura de dois portos, Shimoda e
} 


\subsection{A Restauração Meiji e a retomada do diálogo cultural com Portugal}

Em 1858, o Japão assinou tratados comerciais “com os Estados Unidos, a Holanda, a Rússia, a Inglaterra e a França”, escreve Daniela de Carvalho. "As relações com Portugal só foram retomadas dois anos depois, por insistência de um holandês" (CARVALHO, 2000: 141). Conforme relata Fidelino de Figueiredo: "Em 1860, a corveta D. João I conduzia de Xangai a Yedo o governador de Macau, Isidro Guimarães (...) para, na qualidade de ministro plenipotenciário, negociar um tratado comercial e fazer entrega ao imperador de uma carta autógrafa de el-rei D. Pedro V" (in MORAES, s/d: 24). Conduzindo as negociações com habilidade, o emissário obtém a assinatura do tratado, reatando as relações entre Portugal e o Japão, rompidas há mais de dois séculos - a troca de embaixadores, porém, só aconteceria mais tarde, em 1862, mantendo-se a interdição imperial a qualquer atividade missionária nas ilhas japonesas. A retomada do diálogo cultural entre os dois países logo teve reflexos na produção literária: o próprio comandante da embarcação que levou o governador Isidro Guimarães ao Japão, Marques Pereira, escreveu uma obra intitulada Viagem da corveta D. João I à Capital do Japão no ano de 1860, que apresenta informações acerca da "geografia, da história, da etnologia, das artes, das indústrias, dos costumes sociais e da vida política” do Japão, sem isentar-se de comentários moralistas a respeito dos "banhos públicos dos dois sexos promíscuos" e da "fácil nudez das mulheres", conforme escreve Fidelino de Figueiredo (in MORAES, s/d: 24). Depois da publicação do relato de viagem de Marques Pereira, divulgou-se em Portugal a tradução incompleta da Viagem à roda do Japão, do alemão Rodolfo Lindau, que aborda o cotidiano da vida japonesa de forma menos preconceituosa, admitindo que há outra visão de moralidade na sociedade japonesa. Como resultado de uma nova missão diplomática, liderada pelo Visconde de São 
Januário, surge em 1873 a obra escrita por Pedro Gastão Mesnier: O Japão - estudos e impressões de viagens, impressa em Macau no ano anterior e posteriormente traduzida para o idioma inglês e publicado na China Review, de Hong Kong. A respeito desse autor, escreve Fidelino de Figueiredo, de maneira lacônica, que "percorrera o litoral e o interior em excursões aventurosas, de sorte que identificou lugares que foram cenários de velhos e sangrentos episódios, e autenticou ruínas e estropiados restos" (idem, 26). Nos anos seguintes, a produção literária, memorialística e historiográfica portuguesa a respeito do Japão adquire vulto, com a publicação de obras como Japão por dentro (1904), de Ladislau Batalha, que descreve a sociedade japonesa já em avançado processo de ocidentalização, A estrela de Nagasaki (1907), de Campos Júnior, retrato ficcional da perseguição aos missionários portugueses, Samurais e mandarins (1912), de Luís Guimarães, obra marcada pelo impressionismo e sentimentalismo, além de obras de caráter filológico de Gonçalves Viana e Jordão de Freitas, este último responsável por um trabalho erudito, assim descrito por Fidelino de Figueiredo:

Jordão de Freitas conseguiu descrever sete gramáticas e oito vocabulários e dicionários, compostos pelos missionários jesuítas, e ainda aproveitados no século XIX. A este investigador se devem ainda informes novos sobre a imprensa de tipos móveis, que os portugueses levaram de Macau para o Japão (idem, 29).

No campo da historiografia, convém citarmos Luciano Cordeiro, editor das Batalhas da Companhia de Jesus, do padre Francisco Antônio Cardim; Ayres de Sá, que publicou trabalhos sobre a embaixada que D. João IV enviou ao Japão em 1644, e ainda Antônio Tomás Pires, que fez imprimir o depoimento de um padre franciscano que no século XVI recolhera em Goa o depoimento de um cristão japonês. Fidelino de Figueiredo cita também “o padre Francisco Rodrigues (que) delineou um rápido resumo da ação missionária e cultural dos seus correligionários; e César de Mendes (...), (que) divulgou por tradução o capítulo do livro do professor japonês, dr. Nimura, Nambanqui ou 
Narração dos bárbaros do sul" (idem), que se refere à carta de saudação e aos presentes que D. Duarte de Menezes, vice-rei da Índia, enviou em 1588 ao príncipe japonês Otaico. A obra de Fernão Mendes Pinto, por muito tempo considerada fantasiosa, é revalorizada. "À luz da cartografia da época e da correspondência dos padres jesuítas" escreve Figueiredo, "Cristóvão Aires esclareceu muitos passos da vida de Pinto, corrigiu confusões cronológicas, fixou todas as datas da sua última viagem ao Japão, em 1554-1556, e esclareceu as relações dele com a Companhia de Jesus” (idem, 29-30).

Todas as obras e autores referidos no aqui assinalam o fascínio português pelo Japão, mesclado a um imaginário fantasista e aos preconceitos eurocêntricos recorrentes ao longo do século XIX. Os relatos mais importantes sobre a sociedade e a cultura japonesa que surgiram nesse período, no âmbito da língua portuguesa, foram sem dúvida aqueles escritos pelo diplomata, oficial da marinha e escritor português Wenceslau de Moraes (1854-1929), sobre quem falaremos no tópico seguinte.

\subsection{Wenceslau de Moraes, intérprete da cultura japonesa}

Wenceslau de Moraes exerceu o cargo de cônsul no Japão, após ter prestado serviços em Macau, Timor Leste e Moçambique. "Em seus vários livros", escreve Paulo Franchetti, "Wenceslau de Moraes (...) relata costumes típicos, traduz haicai, comenta a literatura, a arte e a história do Japão, tenta incentivar o comércio e a compreensão entre as suas duas pátrias" (FRANCHETTI, 2012: 38). Ao contrário de outros viajantes europeus, que descreveram a cultura japonesa sob um olhar preconceituoso e racista, "Moraes se esforça por mostrar aos portugueses a grande e sofisticada civilização que se desenvolvia no outro extremo do mundo" (idem). Wenceslau de Moraes, que como oficial da marinha e diplomata visitou e residiu em vários países da África e da Ásia, não adota em seus livros uma visão generalista sobre o "Oriente", preocupando-se, ao contrário, em perceber a especificidade do traço cultural japonês, respeitando seus usos 
e costumes, e inclusive adotando suas vestimentas, idioma e hábitos alimentares. O escritor português converte-se ao zen-budismo, casa com uma japonesa e passa os seus últimos anos em Tokushima, mergulhado no estudo de uma cultura que o encanta.

Em Relance da alma japonesa, volume publicado em 1926, Moraes "fez uma apresentação do haicai que fugiu por completo ao registro do exotismo pitoresco" (FRANCHETTI, 2012: 38), abordando a estrutura da língua japonesa, normas gramaticais, gêneros poéticos e recursos estilísticos de uma literatura que, até então, era desconhecida em Portugal. Relance da alma japonesa não é um livro erudito, nem uma simples narrativa de viagem, mas o documento sincero de um europeu que desejou sentir a cultura estrangeira que tanto o fascinava. No primeiro capítulo da obra, o autor procura justificar o título, definindo a palavra alma como "transcendência, isto é, a significação do pensamento íntimo do indivíduo, dos indivíduos, na apreciação das coisas" (MORAES, 1926: 11). Ele se propõe a "relancear em espírito o modo de ser da família japonesa, no tocante à sua apreciação racial $^{77}$ das coisas, como ela as vê, como ela as sente" (idem). Reconhece a dificuldade do seu propósito, uma vez que "a alma japonesa é, para nós, europeus, e mais do que a de qualquer outro povo, um caprichoso e enorme ponto de interrogação, refratário a quaisquer averiguações" (idem, 15), mas justifica-se dizendo que "não tomo muito a sério a dificuldade em que me vejo. Palestro apenas com o leitor. Relanceio o meio em que me acho; aponto fatos, como eles se dão, ou me parece darem-se; busco tirar conclusões, porém sem esperança de alcançá-las" (idem). Prossegue o autor: "Em todo caso, sigo um método de estudo, para não me desorientar por completo; e chegarei à última página deste livro, sem sombra de remorsos por ter errado mil vezes o caminho para onde me levou a fantasia" (idem). Nas

\footnotetext{
${ }^{77}$ Como um intelectual europeu do século XIX, Wenceslau de Moraes acreditava sinceramente que a identidade e os valores culturais de um povo ou nação estavam relacionados a características raciais, porém, à diferença de autores que expressavam opiniões claramente racistas, ele não faz juízos de valor
} 
páginas seguintes, Wenceslau de Moraes apresentará minuciosas descrições da sociedade japonesa, comentando aspectos de sua religião, idioma, educação, política, literatura, arte, conceitos sobre o amor e a morte, sempre no meio fio entre a informação objetiva e a impressão subjetiva. Sobre a escrita japonesa, escreve o autor:

"Na língua japonesa, quando escrita (ou pintada, porque o pincel substitui a pena), as palavras escrevem-se de cima para baixo e da direita para a esquerda, ao contrário do que sucede com as línguas européias; empregando símbolos gráficos, silábicos, que os japoneses inventaram, ou então os caracteres ideográficos (...). Desse processo de escrever, deriva o fato de que a primeira página de um livro japonês corresponde à última de um livro escrito a nossa moda." (MORAES, 1925: 30)

O autor português, atento à relação entre poesia, caligrafia e pintura, destaca os materiais utilizados na escrita (o pincel, a pena), a diferença entre os sinais gráficos que representam sons e os caracteres ideográficos, que são figuras abreviadas, bem como a peculiar forma de leitura da escrita japonesa, tão diversa da conhecida nas línguas ocidentais. Wenceslau de Moraes observa a relação íntima entre as regras gramaticais e os conceitos filosóficos que moldaram a cultura japonesa com percepção acurada:

Na gramática japonesa, não há artigos; os substantivos e adjetivos são invariáveis, independentes de gênero e de número; quase que não há pronomes pessoais; os tempos dos verbos são invariáveis, independentes de pessoas; não há sujeito gramatical na oração; de sorte que os fenômenos passam-se como que num mundo sem espectadores, sem testemunhas dos fatos, visto que os indivíduos se eliminam propositadamente da cena; estranha coisa, que leva à compreensão da impersonalidade japonesa. (idem, 211).

A diferença entre a lógica gramatical do idioma de Bashô e sua equivalente na língua de Camões não é considerada por Moraes como deficiência ou falha, e sim como reflexo, no mundo das palavras, de conceitos espirituais: "Começamos a adivinhar aqui um conceito da mais alta importância psíquica, na mentalidade do nipônico: a impersonalidade humana, perante os fenômenos da vida" (idem, 35). O agente individual, numa cultura regida pelos princípios de Confúcio e Hui-neng - sexto

depreciativos sobre os japoneses. Sua preocupação está em tentar entender a cultura do outro, sem hierarquizá-la, ao modo dos estudos culturais regidos pelo Orientalismo. 
patriarca do zen budismo chinês -, é algo "de somenos importância, em presença do grandioso drama da natureza criadora" (idem). Prossegue o autor:

Na língua japonesa, se excetuarmos um ou dois termos raramente empregados, que designam a primeira pessoa, pode dizer-se que não há pronomes pessoais. A consequência imediata deste curiosíssimo fenômeno filológico é não haver senão uma palavra para cada modo e tempo de cada verbo. (...) Na conjugação dos verbos japoneses, não se tem em conta as pessoas. (...) Estabelecida claramente esta distinção, pode e deve-se dizer que não existe sujeito gramatical em japonês. Com efeito, ficou notado que a noção de pessoa, isto é, de um ser subsistente e potencial, não existe nesta língua. A consequência rigorosa deste fato é a impersonalidade absoluta no verbo, o qual não exprime mais do que a existência de um acontecimento, de um estado ou de uma paixão, sem relação com a pessoa. (idem, 38)

A impessoalidade, ou ausência de um eu separado do campo dos fenômenos é um conceito caro à doutrina budista. Conforme explica Ricardo M. Gonçalves em seu livro Textos budistas e zen-budistas, "neste contínuo vir a ser que é este mundo, nada existe de substancial e definitivo. Nenhum fenômeno existe independentemente do contexto em que ele se situa, e seu destino é transformar-se, quando o contexto se modifica" (GONÇALVES, 1999: 15). A ausência de um eu, nesta filosofia tão diferente do pensamento religioso cristão e mesmo das doutrinas devocionais do Extremo Oriente, fundadas na dualidade entre o eu e o outro, o divino e o humano, o sujeito e o objeto, está relacionada a outro princípio da metafísica budista, o da interdependência. Segundo Ricardo M. Gonçalves,

as coisas não se definem pelo que elas são em si, mas pela rede de condicionamentos e relacionamentos que as ligam ao contexto. $\mathrm{O}$ homem, ao se analisar, não encontra em si mesmo e ao seu redor nada a que possa se apegar como sendo seu eu, sua personalidade substancial (idem).

A consequência deste pensamento é que o mundo dos fenômenos, sendo vazio de substancialidade e em contínuo processo de transformação, é impermanente: tudo muda o tempo todo, logo, os seres e as coisas não têm realidade estável, fora de situações específicas do espaço e do tempo, daí a analogia com a experiência do sonho. O único Absoluto, conforme a metafísica budista, é o Vazio, ou Sunyata, que é "inacessível ao pensamento e à linguagem" e que "está em todas as coisas e também dentro delas" 
(idem, 13). Este Vazio "é o Uno, a Totalidade de Existência, o Absoluto, mas pode revelar a si mesmo através da multiplicidade dos fenômenos relativos, contingentes e transitórios, assim como a luz só se revela como tal quando incide em corpos opacos que provoquem o contraste luz-trevas" (idem). A arte tradicional japonesa, que expressa este pensamento filosófico, oculta o eu desde a estrutura da língua, ao mesmo tempo que privilegia a representação do vazio, seja nas pinturas a nanquim, seja na arte da caligrafia, na jardinagem ou na arquitetura. Quando os jesuítas portugueses e espanhóis iniciaram sua missão evangelizadora na Terra do Sol Nascente, foi inevitável o confronto entre a concepção dualista da realidade, que considera Deus, homem e mundo como realidades distintas, eternas e inconfundíveis, e o pensamento monista do budismo japonês. Paulo Leminski, comentando o encontro do padre espanhol Francisco Xavier com o bonzo Ninshitsu, escreve:

Xavier fala do amigo: "tenho falado com diversos bonzos ilustrados, especialmente com um que é tido na mais alta estima por todos, pelo seu saber, conduta e dignidade, como pela avançada idade de oitenta anos. Seu nome é Ninshitsu, que em japonês significa 'Coração da Verdade'. É uma espécie de bispo entre eles e, se o nome que usa é apropriado, é realmente um homem abençoado... Esse homem tem sido para mim um amigo maravilhoso".

O diálogo entre eles, porém, não deve ter sido muito fácil.

Xavier ficou confuso, logo de cara, ao conversar com Nishitsu.

O velho mestre zen parecia não saber se "possuía" ou não uma alma. Para ele, era inteiramente estranho o conceito de que "uma alma" era uma espécie de objeto que "alguém" pode estar "possuindo" e até mesmo "salvando". (LEMINSKI, 1983: 77)

Os jesuítas ficaram confusos com a sensibilidade religiosa japonesa, com a sua concepção do sagrado, com o seu modo de vivenciar a espiritualidade na relação harmoniosa com a natureza e nas práticas artísticas, e sobretudo com o seu sincretismo, tão diverso da exigência de exclusividade da religião católica, do islamismo e do judaísmo. Na sociedade japonesa, como observou Wenceslau de Moraes, o budismo, o confucionismo e o xintoísmo conviviam sem grandes conflitos: para um japonês, era 
comum seguir os preceitos confucionistas em suas relações com a família, o professor, o

patrão, o senhor feudal, o imperador, participar das festividades populares xintoístas e adotar o budismo como veículo para a iluminação ${ }^{78}$. Conforme Wenceslau de Moraes,

A doutrina filosófica de Confúcio fora conhecida no Japão muitos anos atrás; mas não criara escola, adormecia, para acordar muito mais tarde, formando adeptos. O budismo, em face do xintoísmo, com este facilmente cooperou, impressionando as massas pelas suas belas aparências rituais e pelas consolações que lhe trazia. Os japoneses encontraram nele aquilo de que o seu espírito carecia, isto é, a afirmação de uma vida eterna após metempsicoses sucessivas; o prêmio da virtude, o castigo da maldade, um paraíso e um inferno, preceitos de piedade a exercer para com os homens e para com os animais, o amor da paz e mil outros dogmas benfazejos. $\mathrm{O}$ budismo pregava-lhes a inconsistência de todas as coisas deste mundo - dos prazeres, dos regalos, da luxúria, dos desejos, das paixões, do amor - chamando-os ao recolhimento, à contemplação exclusiva da divindade e das coisas divinas. $\mathrm{O}$ apelo à abnegação, à simplicidade, calhava bem com a noção íntima que os japoneses nutriam de si próprios, da sua própria impersonalidade; e seguramente a reforçava. Nenhuma outra religião viria mais de molde, como veio o budismo, a colaborar com o xintoísmo, posto que tão diferente dele. O povo abraçou as duas crenças, como se fossem uma.

(MORAES, 19265: 53-54)

Wenceslau de Moraes conhecia bem o repertório filosófico e religioso do Japão, em especial as práticas e princípios do zen-budismo, como percebemos na leitura de seus inúmeros livros sobre a cultura japonesa, como $O$ culto do chá, Fala a lenda japonesa, Relance da alma japonesa, Dai-Nippon e nas Cartas do Extremo Oriente. Essa familiaridade ajudou o escritor português a entender a filosofia da arte que orienta a criação da poesia japonesa, em especial o tanka e o haicai, que ele "reimaginou" - para usarmos um termo caro a Haroldo de Campos, extraído de suas notas sobre a tradução de poemas chineses e japoneses - na forma das quadras portuguesas, sem rimas (a

\footnotetext{
${ }^{78}$ Armando Martins Janeira observa que "os bonzos budistas tomavam normalmente parte dos festivais xintoístas. No Grande Festival dos Primeiros Frutos, de origem e natureza puramente xintoísta, no século VIII, a imperatriz, discípula fiel do Buda, proclamava 'primeiro servir os Três Tesouros (budismo), depois adorar os deuses (shinto) e a seguir amar o seu povo'. (...) Hoje, é fácil encontrar templos onde os símbolos xintoístas do Sol e da Lua figuram ao lado das imagens do Buda. O alargamento do budismo, que se foi tornando cada vez mais popular, não destruiu outras formas religiosas tradicionais, embora as haja transformado. Esta flexibilidade e tendência sincretista do budismo contrasta com a rigidez do cristianismo, que no Japão declarou guerra às religiões xintoísta e budista, destruindo, quando podia, os seus templos" (JANEIRA, 1988: 146).
} 
poesia tradicional japonesa, assim como a grega, não tinha rimas e os ideogramas eram dispostos em uma, duas, três ou quatro colunas). Conforme diz Wenceslau de Moraes:

Para estudiosos portugueses, todavia, o tanka e o hokku não devem merecer tanta estranheza. Nós temos a quadra portuguesa, a nossa deliciosa quadra popular, tão cheia de seduções que, uma só, pode constituir um poema emocionante. Dá-se também a circunstância de serem certos processos de construção, de uso vulgar na poesia japonesa, como o jogo de palavras, o calembur, ou então a reunião de dois períodos, independentes um do outro no sentido, também vulgares na quadra portuguesa. Em minha opinião, a nossa quadra, quando habilmente manejada, seria suscetível de dar excelentes traduções dos poemas japoneses. (MORAES, 1926: 197)

Conhecida desde a Idade Média, a quadra popular era escrita em várias medidas métricas, especialmente a redondilha, também usada no haicai, e é uma das formas mais concentradas da poesia portuguesa. Sua aparente simplicidade, musicalidade e facilidade de memorização também permitem uma aproximação com o terceto japonês, assim como o emprego de palavras de uso cotidiano e jogos de palavras. Wenceslau de Moraes notou o uso recorrente de onomatopeias na poesia japonesa, como "bisho-bisho (ideia de molhar, de alagar); bura-bura (preguiçosamente); chobo-chobo (gota a gota); goro-goro (estrondo de trovão) ${ }^{79 ", ~(M O R A E S, ~ 1925: ~ 30) . ~ O ~ a u t o r ~ p e r c e b e u, ~ c o m ~ o l h a r ~}$ acurado, a ocorrência, no haicai, da "reunião de dois períodos, independentes um do outro no sentido, também vulgares na quadra", que sendo "habilmente manejada, seria suscetível de dar excelentes traduções dos poemas japoneses" (idem). A partir dessa minuciosa investigação da estética do haicai, Wenceslau de Moraes realiza a transcrição do poema japonês para a quadra - e recordemos aqui o emprego da palavra transcrição por Guilherme de Almeida, no artigo Ritmo, elemento de expressão, em que o poeta e tradutor brasileiro usa o termo tal como é entendido na teoria musical, ou seja, "escrever para um instrumento música escrita para outro" (ALMEIDA, 1997: 17). A comparação entre a atividade tradutória e a transcrição de partituras na música erudita, aliás, recorda

\footnotetext{
${ }^{79}$ Décio Pignatari usou a onomatopeia nas traduções que realizou de haicais de Kobayashi Issa, como nesta composição: "Lagos, pingos, tiros: / Quá-quá-quá dos patos patos / Por enquanto vivos". (PIGNATARI, 1996: 79).
} 
uma outra comparação feita por Roman Jakobson em conferência pronunciada em 1967, em Tóquio: "Pode-se mesmo dizer que uma tradução fiel, cerrada, de poesia seja uma contradição em termos. O que permanece passível é a transposição congenial - a resposta livre, criativa, de um poeta de língua inglesa a um autor russo ou japonês e vive-versa", que o linguista soviético compara a "uma transposição inventiva, engenhosa, de um poema ou de um romance em pintura, cinema, balé ou numa composição musical" (in CAMPOS, 1993: 7). A recriação dos haicais japoneses para o formato da quadra, portanto, pode ser considerada uma original releitura de Wenceslau de Moraes, e até uma antecipação das modernas teorias e práticas da tradução, como as desenvolvidas por Ezra Pound. Apesar de toda a sua boa vontade, compreensão conceitual, domínio do idioma e da facilidade com que percorria o território cultural japonês, no entanto, Wenceslau de Moraes não logrou obter, em português, um resultado poético eficaz, comparável aos textos originais japoneses. O poema de Bashô sobre o salto da rã - o mais conhecido de todos os haicais - assumiu a seguinte fisionomia, ao ser transposto para a quadra portuguesa:

Furu-ike ya

Kawaza tobi-komu

Mizu no oto

Versão literal:

Ah, o velho tanque! e o ruído das rãs, atirando-se para a água!

\section{Versão em quadra:}

Um templo, um tanque musgoso;

Mudez, apenas cortada

Pelo ruído das rãs,

Saltando à água, mais nada...

(MORAES, 1926: 198)

A tradução literal da composição de Bashô recorda as versões que seriam feitas, nas décadas seguintes, por poetas tão distintos entre si como Paulo Leminski ("velha lagoa / 
o sapo salta / o som da água ${ }^{80 "), ~ P a u l o ~ F r a n c h e t t i ~(“ O ~ v e l h o ~ t a n q u e ~-~ U m a ~ r a ̃ ~ m e r g u l h a ~ / ~}$ Barulho de água ${ }^{81 ")}$ e Casimiro de Brito ("No velho tanque / uma rã salta - mergulha. / Ruído na água $\left.{ }^{82,}\right)^{83}$, mas, na transcrição para a quadra, Wenceslau de Moraes afastou-se da síntese, da concisão e do estilo elíptico, abrupto, do haicai tradicional, buscando “explicar" o contexto do poema, sua atmosfera física e emocional, inserindo "palavras ou frases que não aparecem na versão literal”, como diz Paulo Franchetti. "O resultado, muitas vezes, deixa a desejar, porque o texto traduzido resulta muito explicativo ou mesmo prolixo.” (FRANCHETTI, 1990: 39) Assim, na versão do haicai para a quadra, Wenceslau de Moraes inclui um "templo" ausente no texto original, adjetiva o tanque como "musgoso", descreve o silêncio que é apenas implícito no poema ("Mudez, apenas cortada...") e acrescenta uma desnecessária ênfase no verso final (“mais nada...”) Podemos recordar o julgamento crítico de Haroldo de Campos a respeito das primeiras traduções de poemas chineses e japoneses, realizadas na década de 1920, consideradas pelo poeta e tradutor brasileiro como presas de um "exotismo edulcorado e fácil" (CAMPOS, 1993: 17), com uma tendência a "transmitir uma réplica aproximativa, vagamente simbolista, frequentemente diluída, do texto original." (idem, 15). A severidade do parecer, no entanto, pode ser exagerada, se aplicada a Wenceslau de Moraes (contemporâneo de Camilo Pessanha, Fernando Pessoa, Mário de Sá-Carneiro), que não era poeta e não teve como objetivo recuperar a informação estética dos textos originais, mas a sua informação semântica (usamos aqui as categorias de Max Bense), a partir de sua vivência no Império do Sol Nascente. $O$ autor não ambicionou a

\footnotetext{
${ }^{80}$ LEMINSKI, 1983: 20

${ }^{81}$ FRANCHETTI, 2012: 81

${ }^{82}$ BRITO, 1995: 13.

${ }^{83}$ R. H. Blyth assim traduz o mais conhecido de todos os haicais: "The old pond; / A frog jumps in, / The sound of the water" (BLYTH, 1981: 246, primeiro volume). Octavio Paz assim traduziu para o espanhol: "Un viejo estanque / salta uma rana zas! / Chapalateo" (in PAZ, 1974: 241).
} 
"reconstituição da informação estética do original em português", contentando-se com "o simples escopo didático de servir de auxiliar à leitura desse original" (CAMPOS: 1978b, 7). Como bem observou Paulo Franchetti,

não é na discutível e interessante proposta de verter o haicai em uma forma tradicional portuguesa que reside o mérito maior de Moraes, e sim em ter enquadrado suas traduções em uma obra que fornece o que é mais raro em relação ao Extremo Oriente: uma visão de conjunto, harmônica e acurada (FRANCHETTI, 1990: 39)

que só foi possível porque o escritor possuía "um verdadeiro conhecimento dos aspectos mais importantes da cultura japonesa" (idem). Na tradução de um haicai de Chiyo-Ni (1703-1775) ${ }^{84}$, Wenceslau de Moraes obtém o seguinte resultado:

\section{Asagao ni \\ Tsurubê torarete \\ Moral mizu}

A trepadeira trepou

Pela corda do pocinho;

Para não a molestar,

Vai pedir-se água ao vizinho.

(MORAES, 1926: 200)

A resposta criativa do autor português à composição de Chiyo-Ni é opaca: o tradutor incluiu rimas (pocinho / vizinho) ausentes na poesia tradicional japonesa e intentou recuperar as sutilezas sonoras do original - de ritmo acentuado e com sugestivas assonâncias e aliterações - empregando uma paronomásia no verso inicial ( $a$ trepadeira trepou), que não reproduz o impacto fônico do texto de partida. A tradução conserva a linguagem coloquial, característica do haicai, mas o contorcionismo métrico e a estrutura rímica tornam o poema excessivamente artificial, distante da simplicidade almejada na arte japonesa, que valoriza a criação espontânea, a imperfeição e a

\footnotetext{
${ }^{84}$ No Brasil, Chiyo-Ni foi traduzida por Alice Ruiz, no livro Dez hai kais (Florianópolis: Editora Noa Noa, 1981), do qual destacamos este poema: "no pântano da montanha / nada se move / na manhã de neve" (RUIZ, 1981: 14)
} 
assimetria, presentes na própria caligrafia. Em operação tradutória similar, Wenceslau de Moraes transpõe para a quadra um curiosíssimo poema, sem referência de autoria:

\author{
Nusundaru \\ Kagashi no kasa o \\ Amê kyu nari
}

\title{
Versão literal:
}

Cai duramente a chuva no chapéu que eu roubei ao espantalho ${ }^{85}$.

\section{Versão em quadra:}

Vai molhando até aos ossos;

Cai a chuva, mais e mais.

No chapéu, que foi roubar

No campo ao "spanta-pardais."

(MORAES, 1926: 202)

A versão literal, escrita em uma única linha, sem medidas métricas nem rimas, numa dicção seca, próxima à da prosa, tem objetividade e força expressiva; a imagem poética revela-se com precisão quase fotográfica. A recriação na forma da quadra, no entanto, revela-se menos eficaz, pela inserção de palavras adicionais para manter a unidade métrica e o jogo de rimas (Cai a chuva, mais e mais) e pela torção sintática nas duas últimas linhas. Apesar do rebuscamento formal, a tradução apresenta algumas soluções interessantes, como a utilização de expressões da linguagem popular (molhando até aos ossos, 'spanta-pardais), recurso frequente nos haicais de Bashô, pouco afeito à fala palaciana. No décimo capítulo de seu livro Relances da alma

\footnotetext{
${ }^{85}$ Wenceslau de Moraes apresenta um comentário à tradução, em que explicita sua dimensão referencial: "Quando o arroz está próximo da colheita, nuvens de pardais caem sobre o arrozal, na ânsia de devorar os bagos, maduros quase. $\mathrm{O}$ aldeão japonês fabrica então uns bonecos, uns espantalhos - e com que arte e graça! - veste-os com quimonos esfarrapados e inúteis, cobre-lhes as cabeças com chapéus de palha, da clássica forma piramidal, mas evidentemente podres à força de uso, não prestando para nada; e dispõe de espaço em espaço, no arrozal, alguns destes monstrengos, em trágicas posturas, a fim de espantarem os pardais. Para o nosso caso, devemos imaginar um pobre diabo qualquer, talvez um estudante pobre - e há tantos estudantes pobres no Japão!... - que fosse caminhando pela estrada, cabeça nua; surpreendido por um aguaceiro, arranca da cabeça de um espantalho o chapéu pobre, enfia-o na própria cabeça e continua o seu caminho, compondo, talvez, por passatempo, a poesia que citei”. (MORAES, 1926: 202)
} 
japonesa, intitulado A arte e a literatura, Wenceslau de Moraes traduz e comenta estes e inúmeros outros poemas japoneses, esmiuçando a dimensão referencial de cada peça, apresentando ao leitor aspectos da história, religião e cultura japonesas, numa linguagem simples e direta, sem debater aspectos técnicos ou linguísticos. Do ponto de vista poético, talvez as suas recriações mais interessantes sejam aquelas feitas em prosa, geralmente em uma única linha, sem preocupação artística; são textos curtos e diretos, que por isso mesmo traduzem de modo mais eficaz o espírito e a forma do haicai tradicional. Entre estas versões ${ }^{86}$, em que predomina a literalidade, destacamos a tradução do haicai de Yayô (1702-1783), poeta menos conhecido do cânone japonês:

\section{Waré to waga}

Kara ya tomurô,

$$
\text { -- semi no kôe! }
$$

Cantando os ofícios fúnebres diante do seu próprio cadáver... -- ai, a voz da cigarra!...

(MORAES, 1926: 105) ${ }^{87}$

Os jogos aliterativos, nesta notável recriação (ofícios fúnebres), respondem de maneira criativa à tessitura sonora do texto original (Waré to waga), bem como a acentuação rítmica (próprio cadáver), e a súbita fratura operada na sentença, que passa de uma descrição para uma evocação, sugere o princípio da montagem na poesia japonesa tradicional. Wenceslau de Moraes, aliás, não se encantou apenas com a poesia clássica, mas também com a poesia popular, que comenta de modo bastante sucinto,

\footnotetext{
${ }^{86}$ Outras traduções interessantes, sem identificação da autoria dos poemas: Furu terá ya / Kanê mono iwasu / Sakura chiru: Oh, o velho templo! o sino não toca; flores de cerejeira caem sobre o solo... e Yuki no mura / Niwa-tori naitê / Akê shiroshi: Aldeia coberta de neve; galos cantando; rompe a madrugada (idem, 200).

${ }^{87}$ Comentando a composição de Yayô, escreve Wenceslau de Moraes: "Basta isso, que é bem pouco, para vir sugerir ao pensamento do leitor uma impressão de delírio, profundamente perturbadora, só comparável àquelas que por vezes nos acodem, dormindo, durante um mau sonho, febril e angustioso; não logrando definir-se por completo no nosso espírito, porque faltam a este aptidões para senti-la; embora o perturbe como que a sensação do sopro frio de um ambiente extraterrestre, aonde houvéssemos mergulhado". (idem, 105).
} 
relacionando-a com o canto, e com os provérbios tradicionais, que conservam o sabor enigmático e paradoxal das histórias zen-budistas. Provérbios populares ou sapienciais foram compilados na Bíblia, em textos religiosos indianos, poemas mitológicos escandinavos, relatos cosmogônicos quíchuas, clássicos chineses e diversas outras literaturas. Sua proximidade com a escrita poética - pela condensação frásica, tom misterioso, oracular, riqueza imagética e metafórica - foi observada por Wenceslau de Moraes, que conclui o seu capítulo sobre a arte e a literatura do Japão apresentando ao leitor uma lista comentada de provérbios, entre os quais destacamos os seguintes:

Enkô ga tsuki wo toran to saru gagotoshi.

(Como os macacos que quiseram apanhar a lua, refletida pelo próprio Buddha na água). Alude-se a uma parábola, contada pelo próprio Buddha, diz-se. Pela noite, alguns macacos, trepados sobre uma árvore, deram fé da imagem da lua, refletida na água de um poço. Oh, lá, a lua na terra, a descansar!... Resolveram sem demora apoderar-se dela. Um macaco enrola a cauda a um tronco de árvore; um segundo macaco agarra-se ao primeiro; um terceiro ao segundo; assim vão alongando a cadeia, até que o último macaco está quase a segurar a lua... Mas então o tronco da árvore verga e parte-se, mercê do grande peso que agüentava, e todos os macacos morreram afogados.

Gun-mô no taizô wo saguru go gotoshi.

(Como uma chusma de homens cegos, a apalpar um grande elefante). - Diz-se daqueles que ignorantemente criticam o budismo. Alude-se à célebre fábula acerca de alguns homens cegos que tentaram de decidir qual a forma do elefante, apalpando-o. Um apalpa a perna e declara que o elefante é semelhante a um tronco de árvore. Um outro, apalpando-lhe a tromba, declara-o semelhante a uma serpente. Um terceiro, apalpando-lhe a anca, diz que o elefante é igual a uma parede. Um quarto, apalpandolhe a cauda, diz que o elefante é semelhante a uma corda...

(MORAES, 1925: 58-59)

Wenceslau de Moraes faz a versão literal dos provérbios japoneses, a partir do idioma nativo, acrescentando notas explicativas, com motivação referencial: é seu propósito familiarizar o leitor de língua portuguesa com as tradições religiosas, lendas e fábulas que inspiraram tais provérbios. Embora não enfatize a função poética, obtém, aqui e ali, resultados interessantes, pela precisão e objetividade, como este: Onna no ké ni wa daizô mo tsunagaru / "Com um fio de cabelo de mulher, até um grande elefante 
pode ser amarrado" (idem, 60). O escritor português conversa com a poesia e as tradições culturais japonesas com espírito receptivo, de quem deseja embebedar-se desse repertório e apresentá-lo de maneira direta e acessível à sua própria comunidade linguística. O excepcional trabalho ensaístico e tradutório realizado por Wenceslau de Moraes no âmbito dos estudos da cultura japonesa só pode ser comparado ao efetuado por seu contemporâneo Camilo Pessanha (1867-1926) em relação à cultura chinesa, que abordaremos brevemente, no tópico seguinte.

\subsection{O caso chinês de Camilo Pessanha}

Radicado em Macau a partir de 1894, após ser aprovado em concurso para lecionar filosofia no recém-criado liceu dessa colônia portuguesa (onde também exerceu a função de juiz), o autor de Clepsidra escreveu ensaios sobre a história, civilização e artes do Império do Meio, colecionou objetos de arte - pinturas, esculturas, caligrafias,

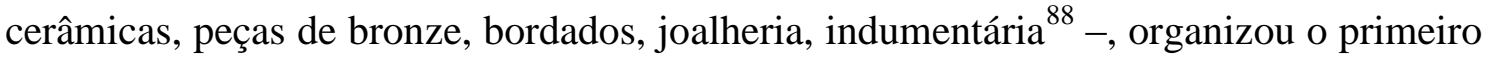
manual que se conhece para aprender chinês: Kuok Man Fo Shu - Leituras chinesas ${ }^{89}$, redigido em colaboração com José Vicente Jorge, e publicou traduções de oito elegias

\footnotetext{
${ }^{88}$ Daniel Pires escreve que "Camilo Pessanha, em colaboração com Lourenço Pereira Marques, recolheu objetos de caráter etnográfico chineses que foram doados à Sociedade de Geografia de Lisboa, e começou a colecionar metódica e criteriosamente peças de arte, empreendimento que acalentou durante todo o seu percurso existencial. Com efeito, peregrinou regularmente pelos antiquários, lojas e prestamistas de Macau, Hong Kong e Cantão em demanda da quinta-essência da arte chinesa. Relata-nos o seu amigo Boaventura Corte real que, em 1914, o escritor adoeceu e pensou que iria morrer proximamente, fixação que o acompanhou sempre e que constitui uma das pedras de toque da sua poética. Decidiu, assim, oferecer ao Estado Português uma coleção de cem peças que foi enviada para Lisboa e ciosamente guardada num armazém anônimo do Museu de Arte Nacional, pois o seu diretor considerou-as de valor irrelevante. Anos depois, o Museu Etnológico de Belém perfilhou também este etnocentrismo artístico, recusando-a liminarmente, de acordo com uma notícia inserta na revista Arte e Arqueologia. Em 1926, Camilo Pessanha convivia diariamente com o espectro da morte: o ópio e uma tuberculose pulmonar minavam-no inexoravelmente. Dois meses antes de falecer, contatou Maia de Magalhães, governador de Macau, com o objetivo de doar ao Estado Português uma segunda coleção de cerca de 220 peças, pondo apenas duas condições para a sua concretização: que se juntasse ao acervo doado anteriormente e que fosse para o Museu Nacional de Machado de Castro, sediado em Coimbra, sua terra natal. Estas premissas foram aceites e o segundo legado veio para Portugal, tendo sido enviado para a exposição de Sevilha de 1929, de onde veio mutilado pois extraviaram-se misteriosamente seis peças." (in PESSANHA, 1993: 8)
}

89 "Espécimen biobliográfico de extrema raridade que, lamentavelmente, não faz parte do patrimônio de nenhuma biblioteca ou arquivo nacionais", conforme escreve Daniel Pires (idem, 9). 
da época da dinastia Ming, valendo-se de seu conhecimento do idioma chinês conhecia nada menos que 3.500 caracteres ideográficos. Em carta de 1912 endereçada a Carlos Amaro, o poeta português escreve: "Bem desejaria publicar um dia meia dúzia de pequenas traduções, mas a empresa, a ser a coisa como eu a tenho esboçado, é cheia de dificuldades" (idem). Considerado as características da língua chinesa “monossilábica, escrita sem modulações gramaticais, apenas uma morfologia posicional, com entonações musicais, que servem para diferenciar muitas sílabas que são idênticas ${ }^{90 "}$ (Donald Kerene) e a forma concentrada das quadras, o poeta escolheu realizar versões literais, quase todas em oito versos, distribuídos em duas estrofes, sem regularidade métrica ou rímica, predominando os versos de doze, treze ou catorze sílabas. Na introdução que escreveu para as suas Oito elegias chinesas, publicadas inicialmente no jornal $O$ progresso, de Macau, o poeta afirma:

Traduzi literalmente - tanto quanto a radical diferença entre o gênio das duas línguas o permite. Esforcei-me por não suprimir nenhuma das ideias contidas no original, por adjetiva e acessória que fosse - embora tendo por vezes de sacrificar a essa imposição de fidelidade os longes de ritmo e a relativa simetria da forma que eu desejaria dar à tradução de cada quadra chinesa, na impossibilidade de as traduzir em quadras de versos portugueses. Menos ainda acrescentei fosse o que fosse no intuito de revelar pormenores, ou com a preocupação de falsos exotismos. Isolei a tradução de cada um dos versos, e dentro dela conservei, nos limites do possível, às ideias e símbolos a ordem original. Isto é, da poesia chinesa busquei trasladar com exatidão o que era trasladável - o elemento substantivo ou imaginativo -; porquanto o elemento sensorial ou musical, resultando de uma técnica métrica especialíssima (em que há sabiamente aproveitados recursos prosódicos de que as línguas europeias não dispõem), é absolutamente inconversível. (idem, 9).

Podemos aqui estabelecer um breve paralelo entre os métodos tradutórios de Wenceslau de Moraes e de Camilo Pessanha: enquanto o primeiro refabulava os poemas, acrescentando, muitas vezes, informações ausentes no texto de partida, para realçar a paisagem e o clima emocional de cada composição (como em sua versão do poema da rã, que o autor reinventa inserindo um "templo" ausente no original de Bashô e o

\footnotetext{
${ }^{90}$ In LEMINSKI, 1983: 33.
} 
adjetivo "musgoso" para qualificar a lagoa), Camilo Pessanha escolhe outro caminho tradutório, buscando a máxima fidelidade ao sentido original, mesmo que ao custo de fazer suas versões em linhas que se aproximam da prosa. $\mathrm{O}$ autor de Clepsidra submetia cada uma de suas traduções à revisão crítica de um eminente sinólogo, o já referido José Vicente Jorge, que, conforme testemunha o poeta, "não só me fez o favor de emendar em alguns pontos a tradução, aproximando-a mais da intenção original, mas forneceume ainda, espontaneamente, grande cópia de notas elucidativas" (idem, 77), que acompanham os poemas recriados. Pessanha valoriza a intervenção crítica do sinólogo, apontando que, sem essas notas, "a inteligência dos textos (mesmo sob o ponto de vista estético) ficaria deficiente" (idem). A importância da literalidade na poesia chinesa, do ponto de vista de Pessanha, reside no "gosto exagerado pela alusão histórica ou literária, que faz com que numerosas passagens, e até poemas inteiros, tenham duplo sentido um superficial e direto e o outro referido ou simbólico, erudito e profundo" (idem). Portanto, conclui o poeta, "em tais condições, o tradutor que não esteja aparelhado com uma vasta cultura sinológica, navega em permanente risco de soçobrar de encontro a inevitáveis, traiçoeiros cachopos" (idem). A compreensão do sentido literal, colocado em primeiro plano em suas traduções, não significa que o autor desconhecia ou menosprezava a extrema poeticidade inerente à escrita ideográfica, bem ao contrário: o poeta português faz referência à "singularidade estrutural" dessa linguagem altamente concentrada, ao "grande poder de evocação visual" e ao "intrínsico valor estético desses caracteres", cada um dos quais "é fundamentalmente um desenho estilizado do mais puro gosto e do melhor efeito decorativo" (idem, 59-60). Pessanha menciona ainda a “euritmia musical da frase escrita, na sua transliteração prosódica, que, pela sábia valorização dos tons, é mais rica, mais expressiva e mais perfeita na literatura chinesa do que o de nenhuma métrica europeia" (idem). Sua ênfase na versão literal, portanto, 
radica numa hipótese de impossibilidade de recuperação das qualidades estéticas da escrita chinesa em línguas ocidentais. Escrevendo sobre esse idioma estrangeiro, tão radicalmente outro, Pessanha destaca o seu caráter tonal, que considera "um elemento prosódico" de "alto valor oratório e poético" (idem, 14), a “imprecisão da linguagem, que no chinês literário é qualidade fundamental, chegando as palavras a não ter significado próprio - tão divergentes e, até, opostas são as acepções de cada uma" (idem, 77) e ainda "a concisão epigráfica - ou, se o leitor assim quiser, telegráfica" (idem), que "manda suprimir quase completamente as palavras designativas das relações lógicas", exigindo do leitor ocidental um esforço imaginativo para a interpretação — "e essa intensidade de sugestão é um dos intraduzíveis encantos da poesia chinesa" (idem, 78). Considerando todas essas dificuldades, Pessanha não intenta uma reengenharia estrutural da poesia chinesa no idioma português, nem utiliza os padrões da versificação portuguesa, optando pelo verso livre, quase em prosa narrativa. Como exemplo da poética da tradução de Pessanha transcrevemos abaixo sua versão da terceira elegia - a mais concisa do conjunto e dedicada a Wenceslau de Moraes ${ }^{91}$ :

\section{SOBRE O TERRAÇO}

(A Wenceslau de Moraes)

Os antigos mortos, invisivelmente

Vêm ainda ao seu terraço antigo...

Já sopra da nona lua o vento lamentoso.

\footnotetext{
${ }^{91}$ Camilo Pessanha e Wenceslau de Moraes conheceram-se em Macau, onde o autor de Relance da alma japonesa se estabeleceu em 1885, para exercer o cargo de professor no liceu. A possível correspondência entre os dois escritores, infelizmente, se perdeu, conforme escreve Daniel Pires, doutor em Cultura Portuguesa pela Universidade de Lisboa, no prefácio ao volume Correspondência, dedicatórias e outros textos, de Camilo Pessanha, publicado em 2013, que reúne 19 cartas do poeta português. Além da dedicatória que o poeta português oferece a Wenceslau de Moraes nesta elegia, há uma breve menção ao escritor no artigo Macau e a gruta de Camões, que Pessanha publica no jornal A Pátria, em 7 de junho de 1924: "Notáveis prosadores (basta lembrar, dentre os contemporâneos, Lafcádio Hearn, Wenceslau de Moraes e Pierre Loti) têm celebrado condignamente os encantos dos países exóticos" (PESSANHA: 1993, 122).
} 
De os três rios $^{92}$ devem estar a chegar os gansos da arribação.

Cobrem nuvens a vastidão dos dois Kuangs ${ }^{93}$.

Declina, pálido, o sol, sobre Pang-Lai ${ }^{94}$.

Desterrado da pátria e sem notícias dela,

Para essas bandas volvo de contínuo os olhos.

(Idem, 85)

A quadra chinesa é aqui reinventada em dois quartetos, sem medidas métricas ou rimas;

o ritmo aproxima-se ao da prosa e o enjambement é empregado nos dois primeiros versos e nos dois últimos. Neste poema, assim como nas demais peças da série, Pessanha mantém palavras em chinês - nomes de rios, pássaros, montanhas, mosteiros num deliberado hibridismo que enriquece a sonoridade dos versos. As mudanças súbitas de paisagem (o terraço dos mortos / o vento / os rios e gansos / o sol sobre Pang Lai) aproximam-se das técnicas de montagem da poesia chinesa e japonesa, propiciadas pela própria estrutura do ideograma, e representam, metaforicamente, o estado emocional do autor do poema, que nas duas últimas linhas lamenta a condição do exílio e o afastamento da mulher amada. É inevitável pensarmos aqui na biografia de Pessanha, em seu desencontro amoroso com Ana de Castro Osório e no exílio voluntário em Macau. A tradução poética pode ser pensada nesse caso como heteronímia ou máscara poética poundiana, em que Pessanha usa a persona de um poeta chinês da Dinastia Ming para expressar sua subjetividade - hipótese formulada por Paulo Franchetti, para quem "a escolha de Camilo Pessanha deve-se provavelmente ao fato de estes poemas espelharem os mesmos traços da sua vivência: solidão, exílio, fuga a um mundo real insuportável e nostalgia da pátria abandonada" (in PESSANHA: 2009, 34). Devemos assinalar também a presença, nas traduções de Pessanha, de características de sua

\footnotetext{
${ }^{92} \mathrm{O}$ poeta se refere ao rio Hiang-tsz-kiang e aos seus dois afluentes.

${ }^{93}$ Referência ao Kuang-Tung e o Kung-Hsi atuais.

${ }^{94}$ P'ang-Lai-Hsian-Kuan, mosteiro taoísta situado a oeste do Cantão. P'ang-Lai - as sarças revoltas - é o nome de três ilhas da mitologia chinesa habitadas pelos Imortais, ou santos taoístas.
} 
própria poética, como a musicalidade, as imagens concisas, o elemento sobrenatural (“Os antigos mortos, invisivelmente"), o tom enigmático, a temática do fluir temporal e a relação analógica entre os planos objetivo e subjetivo, característica da poesia chinesa e japonesa tradicionais. Além das Oito elegias chinesas, que podem ser incluídas no cânon poético de Pessanha (assim como Pound inseriu suas criativas versões de Li T'ai Po, ou Rihaku, em sua obra poética), convém destacar os dois poemas de Clepsidra que dialogam, de modo bastante tênue, com as paisagens e referências culturais do país de Confúcio e Lao Tzu: Viola chinesa, que apesar do título tem uma arquitetura poética mais próxima ao engenho barroco, pelo jogo lúdico das rimas e permutação de palavraschave entre as estrofes (morosa, parlenda), e Ao longe os barcos de flores, em que a agudeza seiscentista predomina sobre a simplicidade, com a repetição da linha "Só, incessante, um som de flauta chora...” entre as três estrofes, à maneira da escrita labiríntica. Diálogo mais explícito com a poesia chinesa parece ocorrer no poema de abertura de Clepsidra, composto de apenas quatro versos - assim como a quadra tradicional chinesa: "Eu vi a luz em um país perdido. / A minha alma é lânguida e inerme. / Oh! Quem pudesse deslizar sem ruído! / No chão sumir-se, como faz um verme $^{95 \%}$. A concisão e os cortes sintáticos desta peça altamente concentrada, assim como a referência ao "país perdido", parecem sinalizar ecos de Cathay, ainda que o tom melancólico e o desejo de extinção remetam antes à filosofia de Schopenhauer, autor de importância decisiva na formação intelectual de Pessanha. O jogo de claro-escuro que se estabelece no texto ("Eu vi a luz em um país perdido" / "No chão sumir-se, como faz um verme"), por outro lado, é novamente um recurso barroco, apropriado pelo leitor fino que foi Camilo Pessanha, para quem a descoberta da China - ao contrário do que aconteceu com Pound - não teve impacto em seu método de criação poética. Conforme

\footnotetext{
${ }^{95}$ PESSANHA: 2009, 53.
} 
escreve Paulo Franchetti, "o mais adequado, no caso das relações entre a poesia de Pessanha e a poesia chinesa (...) não é pensar em influência, mas em reconhecimento, em descoberta de similaridades" (in PESSANHA: 2009, 31), em especial a riqueza imagética, a sonoridade e o caráter sugestivo das linhas - elementos da estética simbolista -, que solicitam a participação imaginativa do leitor para sua decodificação.

Uma questão que merece ser abordada neste tópico é o da seleção dos poemas traduzidos por Pessanha. A terceira elegia, que comentamos há pouco, é uma composição de autoria do obscuro Wang Ting Hsiang, não pertence ao Livro das Odes

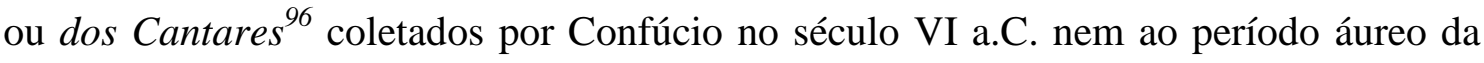
poesia chinesa - a Dinastia T'ang ${ }^{97}$ (618-907), em que destacaram autores como Li T'ai Po, Wang Wei e Tu Fu -, mas à Dinastia Ming (1368-1644), célebre pela sua porcelana, engenharia e arquitetura (datam desse período a conclusão da Grande Muralha e a construção da Cidade Proibida). Pessanha justifica a escolha destes oito poemas de celebração da natureza, da solidão, do exílio e da morte no prefácio que escreveu para as suas traduções, onde afirma: “começarei por uma minúscula antologia de dezessete 98 elegias da dinastia Ming - elegias pelo acento de dolorida melancolia que a todas domina, porquanto a forma, incisiva e curta, é a de verdadeiros epigramas", escolhidas “de entre os inúmeros e vastos cancioneiros da referida época, por um dos mais delicados estetas do Império do Meio nos princípios do século XIX, para presente de

\footnotetext{
96 Existe uma tradução integral do Livro dos Cantares realizada pelo jesuíta português Joaquim A. Guerra, publicada em 1979, em Macau, na coleção Clássicos chineses.

${ }^{97}$ No Brasil, foi publicada a Antologia da poesia clássica chinesa - Dinastia T'ang - com organização e tradução de Ricardo Portugal (São Paulo: Unesp, 2012).

${ }^{98}$ O número total de poemas chineses traduzidos por Pessanha é desconhecido, já que boa parte extraviou-se. No texto de apresentação que escreveu para as suas traduções, em 1914, o poeta declara: "Satisfazendo uma antiga dívida para com o ilustre diretor de $O$ Progresso, entrego hoje ao mesmo semanário umas poucas dúzias de pequenas composições chinesas com cuja decifração tenho entretido os ócios dos últimos seis anos de residência em Macau" (PESSANHA: 2009, 33). Em seguida, afirma que o início dessas publicações seria um conjunto de dezessete elegias, das quais conhecemos apenas oito, publicadas no referido jornal.
} 
despedida a um amigo íntimo que para longe se ausentava" (idem, 75). O compilador dessas composições, escreve Pessanha, "foi o ministro Iong Fong Kong, que ao tempo (no reinado de Chia-King) exercia em Pequim os mais elevados cargos do estado, inclusive o de mentor do príncipe herdeiro" (idem). Tais poemas chegaram a suas mãos "trazidas de tão longe como relíquia preciosa - adaptadas a álbum (com capa de rica madeira das Filipinas, em que havia esculpido o nome em um breve elogio do Mestre), e encerrado tudo em um estojo de tamarindo de dupla tampa" (idem). Na dedicatória ao conjunto de poemas, prossegue, "se declara que os versos são do tempo dos Ming. Nenhuma informação acerca do autor ou autores, senão que viveram nesse período (1368 a 1628)" (idem). A identificação da autoria de cada composição foi possível graças "à direção de um letrado chinês" (idem), e, a partir das indicações fornecidas por ele, Pessanha nomeou, nas notas, a autoria de cada peça. Por qual motivo esta coleção de poemas chamou a atenção de Pessanha, mais do que as peças líricas de um Li T’ai Po, considerado o maior poeta da China? Não temos nenhum registro do autor - carta, ensaio ou resumo de conferência - que permita chegarmos a uma conclusão definitiva, e é bastante provável que sua obra tradutória, em grande parte, tenha sido perdida. Uma hipótese formulada por Paulo Franchetti é que o poeta teria escolhido composições da Dinastia Ming exatamente por serem "poemas inéditos em línguas ocidentais, produzidos não por luminares da poesia chinesa, mas por autores menos divulgados e apreciados pelo público" (in PESSANHA: 2009, 33). A seleção feita pelo autor da Clepsidra, prossegue o autor brasileiro, "deveria ser suficiente para sugerir, mesmo aos menos atentos, a amplitude de referências chinesas do poeta, bem como para indicar o seu grau de conhecimento do idioma, pois não pode apoiar-se em traduções para outras línguas ocidentais" (idem). A morte prematura do poeta, aos 59 anos, bem como o extravio de parte de seus papeis, não nos permitem saber qual era exatamente o seu 
projeto tradutório, se intencionava traduzir também excertos do Livro dos Cantares e outras joias de uma literatura milenar, ou se a sua seleção fora principalmente temática, por afinidade com a sua própria poesia, à maneira da heteronímia. Este é um problema que poderá talvez ser elucidado em anos vindouros, caso venham à luz obras extraviadas de um autor de memória prodigiosa, incansável curiosidade intelectual e rara sensibilidade para a compressão de uma cultura tão distante da sua. Além das Oito elegias chinesas, Pessanha legou-nos os artigos, ensaios e resumos de conferências que tiveram publicação póstuma, sob o título de Escritos sobre a civilização chinesa, principal fonte de informação para o presente texto. O profundo interesse e respeito de Pessanha por uma tradição poética radicalmente diferente da europeia e o desejo de relacionar-se com ela por meio da tradução e da reflexão crítica terão desdobramentos na segunda metade do século XX, na obra de autores como Armando Martins Janeira, Casimiro de Brito, Herberto Helder, Ana Hatherly, E. M. de Melo e Castro, Yvette Centeno, Eugênio de Andrade e Albano Martins, que estudaremos no terceiro capítulo desta tese. 


\section{CAPÍTULO III}

\section{O DIÁLOGO CRIATIVO LUSO-JAPONÊS NA CONTEMPORAINDADE}

\section{1 - Armando Martins Janeira e o teatro lírico japonês}

Um dos principais responsáveis pelo diálogo criativo com o Japão na segunda metade do século XX foi Armando Martins Janeira (1914-1988), autor de livros como Nô - teatro lírico japonês (1954) e O impacto português sobre a civilização japonesa (1970), que comentaremos neste tópico. O escritor português, que fez carreira no Ministério dos Negócios Estrangeiros, foi primeiro secretário da legação diplomática portuguesa em Tóquio, entre 1952 e 1955, e depois embaixador, no período entre 1964 e 1971, fundou a Associação de Amizade Portugal-Japão e o Instituto dos Estudos Orientais da Universidade Nova de Lisboa, onde também lecionou História Contemporânea das Civilizações Orientais. Assim como Wenceslau de Moraes, foi um homem de ação e pensamento, apaixonado pela cultura japonesa; mas, diferente do solitário de Tokushima, incorporou em seus livros uma quantidade maior de informações históricas, em linguagem sóbria, quase jornalística, evitando o impressionismo e o sentimentalismo presentes em numerosas páginas de seu ilustre predecessor. O livro $N \hat{o}^{99}$ - teatro lírico japonês, publicado em Tóquio no ano de 1954, numa edição bilíngue ilustrada de apenas 250 exemplares ${ }^{100}$, chama nossa atenção por ser uma das primeiras traduções para o português de peças desse gênero poéticodramático considerado por Steinilber-Oberlin e Kuni Matsuo como a "quinta essência

\footnotetext{
99 Conforme escreve o autor: “A palavra Nô significa 'talento' e daí exibição de talento, representação elaborada por um conhecedor com gosto e sentido dramático.” (JANEIRA: 1954, 5-6) Darci Yasuco Kusano identifica, no ideograma do nô (能), os seguintes significados: "trabalhar com toda a sua força" + "mostrar o corpo de uma maneira diferente (persona)" + "os pés da tartaruga (representando a vitória da persistência que, em sua forte e tenaz energia, consegue vencer a lebre (ligeira)" = "realização, habilidade, talento, e por extensão, talento numa apresentação”. (KUSANO: 1983, 31)
} 
da poesia japonesa" (in CAMPOS, 1993: 13), e especialmente a peça Hagoromo (羽衣, “O manto de plumas"), traduzida também pelo poeta norte-americano Ezra Pound (em Certain noble plays of Japan, de 1916, republicada no volume The translations of Ezra Pound, 1953) e pelo brasileiro Haroldo de Campos (Hagoromo de Zeami, 1993).

O autor português escreve no prefácio da obra que "não foi por virtude do interesse teatral, mas sobretudo pela sua qualidade poética, que me senti tentado a por em português Kantan, Yuki e Hagoromo. Estes três poemas foram o que de mais belo encontrei traduzido da literatura japonesa" (JANEIRA, 1954: 5). Com efeito, Janeira demonstra pouco apreço pelas formas poéticas curtas, o haicai e o tanka, que ele considera "impróprias para exprimir uma larga gama de emoções", o que as tornaria “muito pobres em comparação com a poesia do Ocidente” (idem, 3). A severa avaliação do autor é baseada na suposição de que, entre os poemas escritos em formas breves, há poucos que falam "de exaltação religiosa, poucos que toquem senão vagamente a metafísica ou a ética" (idem). A tradução dos haicais japoneses para o português realizada por Wenceslau de Moraes também é criticada por Janeira:

... foi descoberto que, para o gosto ocidental, que demanda na poesia profundidade de concepção e largueza criativa, as melhores obras da poesia nipônica não estavam nas coletâneas clássicas, onde na verdade se encontram jóias raras, do Manioshu (Coleção de dez mil folhas), compilado nos séculos VII e VIII, do Shin Koshinshu (Coleção de poemas antigos e modernos) datado de 905, e do Hiakuninshu (Cem poesias de cem poetas), de 1235, aliás muito venerado num país onde o respeito pela tradição e pela antiguidade substitui muitas vezes a apreciação do valor intrínseco. Mas mesmo aqui, poucas vezes penetra a curiosidade do corrente leitor europeu. Porque este, alheio a essas veias ricas da criação do espírito japonês, quase se tem limitado a degustar alguns exemplares refinados da poesia curta do haikai e do tanka. Foram estes os que Venceslau de Moraes nos revelou, e quase sempre com bem pouca exatidão.

(JANEIRA, 1954: 1-2).

Surpreende, num autor inteligente e bem-informado como Janeira, que abordou com objetividade e riqueza de detalhes tantos aspectos da cultura e da sociedade

\footnotetext{
${ }^{100}$ Para a redação deste tópico foi consultado o exemplar disponível no acervo do Centro de Referência Haroldo de Campos, na Casa das Rosas, em São Paulo.
} 
japonesas, essa incompreensão ao mesmo tempo estética e filosófica; o haicai, como vimos no primeiro capítulo, é uma forma poética embebida de vivência espiritual zenbudista - se difere de O paraíso perdido de Milton ou da Divina comédia de Dante em extensão de linhas e quantidade de informações históricas e culturais, não é menor como manifestação de uma religiosidade que é experimentada no cotidiano, seja na meditação silenciosa, seja nas pequenas ações da jornada ordinária ou na observação da natureza o salto de uma rã, o voo de um pato, o capim comido pelo cavalo. Há nessa avaliação de Janeira uma incompreensão da simplicidade da mística japonesa, que prescinde de longos volumes de ética ou metafísica, como a Suma Teológica de Tomás de Aquino, mas nem por isso é vivida com menos profundidade. Estudiosos ocidentais como Donald Keene, inclusive, estabelecem sugestivos paralelos entre o poema curto japonês e o teatro nô: “O nô providencia um molde soberbo para um poeta dramático. Em certo sentido, é um equivalente amplificado do haicai, apresentando apenas os momentos de maior intensidade, como a sugerir o resto do drama" (in CAMPOS, 1977: 58). A montagem ou justaposição de signos, elemento estrutural do haicai, está presente também nas peças de teatro nô, que podem ser entendidas como longos poemas construídos pela sequência de peças breves. Eico Suzuki, no livro Nô - teatro clássico japonês, afirma que o nô é dividido em três partes: jô, prelúdio; ha, movimento; e kiu, final. No prelúdio, o protagonista canta, sozinho ou acompanhado pelo coro, o sashi, ou sentimento que caracteriza o personagem; no movimento, acontecem os diálogos entre o protagonista e o coadjuvante, e no final " o coadjuvante canta o Matiutai ou Canto de Espera, compassado - Deuá; aqui, o(a) protagonista posterior reaparece, baila ou não, podendo cantar, sem compasso, um poema uaca" (SUZUKI, 1977: 68). Lentamente, o canto evolui e se torna "festivo, trágico ou sentimental ou ainda vitorioso, conforme o caso, pelo Kiri, canto finalíssimo, compassado, pelo coro" (idem). Donald Keene, em 
sua analogia entre o haicai e o nô, comenta: "Como o haicai, também o nô possui dois elementos, sendo que o intervalo entre a primeira e a segunda aparição do dançarino principal desempenha a função de corte do haicai, devendo o auditório suprir o elo entre ambas" (in CAMPOS, 1977: 58) ${ }^{101}$. A concisão, elemento-chave da estética do haicai, também comparece na forma da atuação do nô, que é reduzida ao mínimo, em sua representação simbólica - basta um simples movimento de leque do ator-bailarino para indicar a morte de uma personagem, conforme exemplo citado por Haroldo de Campos no ensaio Hagoromo: plumas para o texto, incluído no livro A operação do texto ${ }^{102}$. René Sieffert, comentando Hagoromo, que traduziu para o francês, escreve que a ação da peça "é quase inexistente, e o texto não é senão um longo poema que canta a natureza primaveril” (in CAMPOS: 1993, 13). Cenários, música, dança, interpretação, gestualidade, todos os elementos dessa forma dramática intersemiótica são apresentados com o máximo de economia, desafiando o demônio da eloquência e da retórica (e podemos recordar, aqui, a síntese feliz de R. H. Blyth, no primeiro volume de seu livro Haiku: "In a Nô play, the action takes place in a world where movement represents stillness, and the stillness is not immobility but a perfect balance of opposed forces."). A inclinação da arte japonesa para a contenção e brevidade, como apontou Haroldo de Campos, faz parte de um "programa geral de beleza” próprio da civilização nipônica, uma "tradição viva" que não é apenas "conservada" mas também "vivificada" (CAMPOS: 1976, 119) ao longo das gerações, o que pode ser observado não apenas nas artes tradicionais - "obras de arte visuais, sonoras ou verbais", mas até "no mais humilde artefato cotidiano" (idem). Kunio Komparu, um dos especialistas contemporâneos em teatro nô, estabelece outra interessante analogia entre o drama lírico

\footnotetext{
${ }^{101}$ A divisão ternária, presente no haicai, no ikebana e no teatro nô, conforme vimos no primeiro capítulo, corresponde ao simbolismo Céu-Terra-Homem da filosofia taoísta e do zen-budismo.

${ }^{102}$ CAMPOS: $1976,120$.
} 
e o poema curto japonês: "poderíamos comparar o enredo a um poema do tipo haicai, caligrafado num cartão especial: não se lêem apenas as palavras, mas se apreciam o arranjo e a forma dos caracteres, a utilização das pinceladas de tinta e até mesmo os espaços deixados em branco", assim como, na apresentação de uma peça como Hagoromo, "admiramos não apenas o entrecho, mas o modo de atuar, o canto e o ritmo" (in CAMPOS: 1993, 13). Claro: no teatro nô acontece uma experiência estética que envolve de maneira mais intensa os sentidos do espectador, por envolver recursos visuais, sonoros e imaginativos, mas importa ressaltar que em ambos os casos não se trata apenas da apreciação da letra ou do sentido, mas de todos os elementos estéticos presentes no objeto artístico. Apesar de sua incompreensão quanto ao haicai - e podemos apresentar aqui, em defesa do autor, o fato de que residia no Japão há apenas dois anos, como secretário da legação diplomática, e ainda não estava plenamente familiarizado com a cultura da Terra do Sol Nascente - Armando Martins Janeira observa, com agudeza, alguns elementos essenciais da poesia dramática japonesa:

Nenhuma outra forma teatral fundiu duma maneira tão harmoniosa e bela os elementos díspares da representação cênica. Esta pureza é atingida pelo alto simbolismo do texto e do jogo cênico. Os símbolos puros de que faz-se uso dá-lhe eloquência e brevidade; a riqueza de sugestões dispensa longas declarações de palavras. Alguns passos simbolizam uma longa jornada; uma pedra representa a montanha; um ramo de árvore, a floresta. Esta simplicidade de meios dá-lhe uma nobreza direta e eloquente. (JANEIRA, 1954: 6)

O escritor português observa também que as "expressivas máscaras, a imobilidade estatuária das figuras, e, sobretudo, a dança, que constitui o centro da peça, e que está na sua origem, procuram dar movimento, cor e interesse à declaração do texto", que é escrito em uma "língua antiga", “incompreensível ao ouvido da assistência” (idem, 8). A língua usada nos monólogos e diálogos das peças de teatro nô, efetivamente, não é contemporânea da época em que estas foram escritas (a partir do século XIV): conforme Haroldo de Campos, trata-se de um "coloquial de corte, anterior de pelo menos um 
século, vetusto, isento de qualquer vulgaridade" (in CAMPOS, 1993: 14) ${ }^{103}$. No mesmo texto, que antecede sua tradução da peça Hagoromo, de Zeami, Haroldo de Campos diz: “O nô combina passagens em verso (sob a forma de canto ou de recitativo) com outras em prosa (kotoba), declamadas de forma lenta e solene, sem acompanhamento musical" (idem). A entonação e o canto, nesta singular modalidade de teatro musical dançado, seria comparável 'aos modos gregorianos, ou, talvez, ao Sprechgesang ('canto falado') da música moderna", continua Haroldo de Campos, recordando também que "a parte lírica e os coros compreendiam citações de poesia japonesa e chinesa e de narrativas clássicas de prosa permeada de poesia", como por exemplo a célebre Gengi monogatari, escrita no século XI por Murasaki Shikibu, "uma proustiana Dama da Corte do requintado Período Heian ${ }^{104, "}$ (idem). A trama intertextual dos textos poéticos do teatro nô, à qual devemos acrescentar toda sorte de trocadilhos e jogos verbais, permite a comparação com um "brocado de seda" (idem), na feliz comparação feita por Campos.

Armando Martins Janeira observa, assim como o seu colega brasileiro, o caráter intersemiótico das peças do repertório nô, ressaltando os aspectos litúrgicos e coreográficos dessa poesia dançada, em vários sentidos comparável à ópera ocidental (e em particular à gesamtkunstwerk, ou "obra de arte total" wagneriana): "O nô é um drama lírico de origem religiosa (...). À semelhança do teatro europeu, nasceu das festas religiosas, em que se louvavam os poderes e as graças dos deuses e mais tarde os feitos e quedas dos heróis” (JANEIRA, 1954: 5). Com efeito, escreve Darci Yasuco Kusano, “o teatro nô nasce das apresentações cômicas populares: dengaku e sarugaku (idem, 6),

\footnotetext{
${ }^{103}$ Conforme Darci Yasuko Kusano, "os textos das peças de nô, em escrita arcaica, bastante estilizada e feita com pincel, são compostos de uma mistura de prosa e versos de 7 e 5 sílabas, inseridas no compasso de quatro por quatro. Apresentam freqüentes alusões a referências budistas, citações de versos chineses e japoneses, trocadilhos interessantes, e são cantados e declamados na linguagem da era Kamakura (11921332)". (KUSANO, 1984: 31)

${ }^{104}$ Donatella Natili observa que, "na história da literatura japonesa, a produção literária feminina ocupa um lugar de destaque, tanto que os primeiros grandes romances em língua japonesa foram escritos, no período Heian (794-1185), pelas damas da corte”. (in AKIKO, 2007: 14-15.)
} 
sendo que o primeiro "constituía-se de canções e danças apresentadas pelos agricultores e sacerdotes durante os festivais agrícolas dos arrozais, augurando uma boa colheita", enquanto o segundo "era uma espécie de farsa, da cidade, incluindo shows com animais, saltimbancos e truques de mágica" (idem). Ambas as formas dramáticas, prossegue a autora, "eram um misto de canto, música e acrobacia, com que a nobreza de Kyoto, entediada com a música palaciana, se divertia.” (KUSANO, 1984: 15-16) Estas formas de teatro popular foram reelaboradas e refinadas no século XIV por Motokiyo Zeami (1363-1443), que criou um teatro aristocrático, culto e elegante, apresentado nas cortes. Zeami, um "verdadeiro espírito renascentista", segundo Darci Yasuco Kusano, foi "cantor, compositor, coreógrafo, poeta, o maior ator e autor de nô de todos os tempos" (KUSANO, 1983: 27-28), além de ter escrito 23 tratados sobre o nô, transmitidos secretamente por quase cinco séculos, sendo divulgados apenas a partir de 1909. Entre esses livros destaca-se o Fushi-kaden (da transmissão da flor da interpretação), "também conhecido por kadensho (o livro de transmissão da flor)", composto de sete volumes, considerado "a bíblia do nô" (idem). O novo teatro que surge a partir da reforma da arte dramática realizada por Zeami é composto de 800 peças, "das quais se mantêm hoje no repertório das várias escolas uma terça parte" (JANEIRA: 1954, 6), que se destacam pela "elevada beleza lírica do texto e a pureza da realização cênica" (idem). Os temas desse repertório dramático foram buscados nas tradições "shintoístas e budistas, algumas dessas provindas da China, e às grandes obras da literatura nipônica" (idem), e a parte musical, segundo Darci Yasuko Kusano, era executada por uma pequena orquestra composta de "um instrumento de sopro, o nokan, a flauta de nô, que provê o tema melódico, e três instrumentos de percussão, que marcam o ritmo da peça: kotsuzumi, tamboril pequeno, otsuzumi ou okawa, tamboril grande, e taiko, tambor 
achatado" (KUSANO, 1984; 48). Máscaras (que representam deuses, seres sobrenaturais, anciãos e personagens femininos, sendo todos esses papeis representados exclusivamente por homens), indumentária e cenário estilizado completavam a representação, que buscava causar no espectador uma profunda reação psicológica, quase religiosa. Conforme escreveu Zeami: "Esqueça o teatro e olhe para o nô. / Esqueça o nô e olhe para o ator. / Esqueça o ator e olhe para a ideia $\left(\right.$ kokoro $\left.^{105}\right)$. / Esqueça a ideia e você compreenderá o nô" (in CAMPOS, 1993: 24).

O caráter antinaturalistado teatro lírico japonês faz-nos recordar o drama poético intentado por Mallarmé em peças como Hérodiade e L'après-midi d’un faune, onde praticamente nenhuma ação acontece ${ }^{106}$, bem como a advertência estampada pelo autor francês em Igitur: 'Ce conte s'adresse à l'Intelligence du lecteur qui met les choses em scène, elle-même" (MALLARMÉ, 1984: 10). Com efeito, poetas filiados ao movimento simbolista, como Paul Claudel - que definiu o nô como uma "ampla tapeçaria de imagens e de sentenças ${ }^{107,}$-- e W. B. Yeats intentaram criar dramas estáticos, com ressonâncias diretas do teatro nipônico. Conforme observou Armando Martins Janeira, "Claudel, fascinado por essa arte, chamou para ela a atenção com a autoridade disseminadora dum grande escritor. É a poesia do nô. Chamberlain e Revon deram-nos delas as primeiras amostras insuficientes. Gabriel Péri penetrou-lhe os segredos da linguagem" (JANEIRA, 1954: 3). Porém, foi o irlandês W. B. Yeats que, “inspirado nela, tentou criar uma nova forma de teatro, 'distinta, indireta e simbólica'” (idem), em especial o drama At the hawk's well. Janeira aponta ainda a ressonância do nô em obras

\footnotetext{
${ }^{105}$ Kokoro, em japonês, significa ao mesmo tempo coração e pensamento.

106 Hérodiade é dividido em três partes: Abertura antiga, Cena e Cântico de São João. Apenas na segunda seção da peça-poema acontecem três pequenos gestos da Ama, seguidos de três recusas da protagonista.

${ }^{107}$ In CAMPOS, 1993: 15.
} 
de Gordon Bottomley, Lawrence Binion e Thornton Wilder, autor de A nossa cidade (Our town).

A despeito da influência do nô em peças do repertório ocidental a partir do final da segunda metade do século XIX, traduções significativas, até meados de 1950, eram relativamente poucas - entre elas, a versão francesa de Sieffert, as inglesas de Waley e Pound, a espanhola de Esther Tato Borja (esta última, realizada a partir de versões inglesas). É possível afirmar que Armando Martins Janeira realizou a primeira tradução poética de peças do teatro japonês para a língua portuguesa, a despeito de seu desconhecimento do idioma original - Janeira valeu-se da colaboração de Yoshitomo Okamoto e Oshima Akiko, além de consultar as versões inglesas e francesas das três peças que escolheu para adaptar ao português: Kantan (邯鄲), Yuki (雪) e Hagoromo (羽衣), esta última considerada a mais representativa peça do teatro lírico japonês. Apesar de não ser poeta (assim como Wenceslau de Moraes), Janeira obtém bons resultados na tradução, mantendo a concisão, a ênfase nas imagens e no ritmo dos versos, especialmente na versão de Hagoromo - que ele traduz como $O$ manto de penas. Eico Suzuki, no livro Nô - teatro clássico japonês, assim resume o enredo da peça:

Hagoromo de Zeami passa-se na primavera, no país de Suruga, pinheiral de Miho, onde se avista o sagrado monte Fuji - hoje, local turístico famoso. O pescador Hakuriô, passeando pela baía de Miho, descobre, sobre a ramagem de um pinheiro, maravilhoso manto de plumas. Quando tenta levá-lo para casa, é interpelado por bela personagem, confessando-se dona do manto, o qual não deve pertencer a um humano. O pescador, reconhecendo uma donzela celeste - espécie de anjo budista - mais razão acha para levá-lo. Ela se lamenta vendo os pássaros e nuvens correrem em direção a sua morada, inatingível sem o manto, que lhe permite voar. Penalizado, ele propõe sua troca por danças divinas. Mas só com o manto a donzela poderá bailar. O pescador objeta, uma vez de posse do manto, ela fugirá sem cumprir a promessa. 'Não' - diz ela - 'a desconfiança só existe entre os homens. No céu, não existe a mentira'. Envergonhado, Hakuriô faz a devolução. $O$ anjo se veste e baila, cantando as maravilhas do céu e do Palácio da Lua, onde mora. E desaparece entre a neblina, à altura do Monte Fuji. (SUZUKI, 1977: 109-110)

As peças do repertório nô eram classificadas de acordo com a posição hierárquica do protagonista, que pode ser um deus ou deusa, demônio, ancião, samurai ou dama de 
notável beleza. Hagoromo pertence à categoria katsura-mono (鬘物) ou sanbanmemono (三番目物), em que o drama está centrado na história de uma heroína - no caso, uma tennin (天人), anjo ou ninfa budista. Conforme escreve Haroldo de Campos, "nela, a 'sutileza' e o 'charme' - qualidades resumidas na palavra-chave yugen - prevalecem, ao invés da violência, característica das peças que têm como protagonista um demônio ou uma aparição fantasmagórica" (CAMPOS, 1993: 13-14). Para manter as qualidades poéticas associadas ao princípio de yugen, o tradutor português adotou uma linguagem deliberadamente sugestiva, musical, próxima à dicção simbolista, sem perder de vista a concisão, a alta definição das imagens e o tom narrativo, mais adequado à recitação no palco. Assim, logo no início da peça, Janeira assim traduz o coro dos pescadores:

Os gritos dos remadores

Bradam no vento célere

Sobre as ondas da Bahia de Miho

Para o mar largo.

(JANEIRA, 1954: 22)

Em versos breves, construídos sem medidas métricas nem rimas (nos textos originais japoneses, há linhas de cinco e sete sílabas), Janeira reforça o efeito sonoro utilizando jogos de assonâncias e aliterações, ao mesmo tempo que mantém fidelidade ao sentido literal (preservado na tradução inicial do texto, realizada por Oshima Akiko). Podemos recordar, aqui, as palavras de Jorge Luís Borges sobre a versão literal, em seu artigo Música da palavra e tradução (que integra o volume Esse ofício do verso): "De fato, pode-se dizer que traduções literais contribuem não só, como salientou Matthew Arnold, para o estranhamento e a bizarria, mas também para a singularidade e a beleza" (BORGES, 2000: 74). Isto ocorreria, segundo o autor argentino, porque "se examinamos uma versão literal de algum poema exótico, esperamos algo estranho. Se não encontramos, ficamos meio desiludidos" (idem). A literalidade apontada por Borges no referido texto não se refere, claro está, apenas ao sentido, mas também à singularidade 
da forma do texto original. Quando o capitão Burton traduziu As mil e uma noites, por exemplo, ele criou uma versão literal do título, Livro das mil noites e uma noite, artifício que "é fiel, palavra por palavra, ao árabe. Porém, é falsa no sentido de que as palavras 'livro das mil noites e uma noite' são uma fórmula comum ao árabe, enquanto em inglês temos um ligeiro choque de surpresa. E isso, claro, não era pretendido pelo original" (idem). Do mesmo modo, em outro exemplo citado por Borges, o Shikr HaShirim, livro hebraico que está na gênese da poesia erótico-amorosa do Ocidente, é comumente traduzido como $O$ cântico dos cânticos, numa operação linguística que introduz, nos idiomas ocidentais, uma figura de retórica própria da língua e cultura hebraicas, "que não tinham superlativos, daí não poderem dizer 'o mais sublime dos cânticos' ou 'o melhor dos cânticos"' (idem, 73-74). Esta singularidade (presente também em outras páginas da Bíblia, como na designação "rei dos reis") foi menosprezada por Lutero, que, mais atento à utilidade didática e missionária do que à poeticidade, traduziu Shikr Ha-Shirim como Das hohe Lied, ou "elevada canção" (idem). A tradução literal, tal como entendida por Borges, aproxima-se das teses defendidas por Walter Benjamin e Haroldo de Campos, que propunham contaminar o texto de chegada com a voz singular do texto de partida, mesmo incorrendo no risco (assumido) de construção de um texto artificial ou híbrido, distante do uso natural da língua (e podemos recordar, nesse ponto, que o repertório das peças de teatro nô foi escrito numa língua já arcaica no tempo de Zeami). Assim, na tradução do mesmo canto de Hagoromo, Haroldo de Campos chega a um resultado bem diverso:

Singram barcos ao largo da Bahia de Miho.

Os brados dos pescadores marcam a rota das ondas.

(CAMPOS, 1993: 35)

$\mathrm{Na}$ tradução de Janeira, temos a reprodução exata do sentido do texto japonês (que se encontra transliterado e traduzido, palavra por palavra, em algumas edições da peça: 
Kaza wakizure / Miho no urawa o kogu fune no / Urabito sawagu namiji kana, lemos no apêndice elaborado por Eico Suzuki e Darci Yasuko Kusano para o livro Hagoromo de Zeami), mas a reconfiguração dos efeitos sonoros é opaca; já na versão de Haroldo de Campos, mais sintética (apenas duas linhas), há maior riqueza rítmica, com as aliterações em /b/ e /g/, bem como a disseminação do fonema AR: singRAm, 1ARgo, bARcos, bRAdos, mARcam, RotA. Uma outra passagem do drama japonês, tsukimo nokori no ama no hara. Oyobinaki mi, assim é traduzida por Janeira: "Chegou a Primavera aos pinheirais de Miho" (JANEIRA, 1954, 22), frase meramente referencial, desprovida de informação estética; na versão do poeta brasileiro, o verso ficou assim: “(...) o pinheiral / Espera a primavera: cor-aroma” (CAMPOS, 1993: 35), em que a palavra PinhEiRAl sai esPERA e rima com PRimavERA, além do jogo sinestésico “coraroma", aliás derivado da tradução poundiana breath-colour. As inventivas recriações de Haroldo de Campos trazem para nossa língua os trocadilhos e jogos sonoros próprios do kakekotoba, recurso frequente nas várias modalidades da poesia japonesa e com frequência ignorado na maior parte das traduções para línguas ocidentais, pelo alto grau de dificuldade para sua transposição para outro campo semântico. Em comparação com as versões haroldianas, o esforço tradutório de Armando Martins Janeira pode parecer, no início, bastante modesto; porém, se pensarmos nas possibilidades de encenação da versão portuguesa de Hagoromo, tudo muda de figura. "O manto de penas" não é apenas um texto para ser lido, como literatura, mas para ser encenado - e podemos supor que Janeira concebeu uma versão literária eficaz para a declamação no palco, onde importa mais a habilidade do ator, especialmente sua prosódia, que um artesanato linguístico que requer a atenção da leitura silenciosa. A versão de Janeira, menos virtuosística e numa dicção próxima à da língua falada, parece-nos mais adequada para a representação no palco, onde não é a palavra sozinha que reina, mas a conjunção de 
cenários, indumentária, máscaras, gestos, música instrumental, monólogos e diálogos, unificados de forma orgânica. Como ilustração do que afirmamos, reproduzimos, a seguir, um fragmento do final de Hagoromo / "O manto de penas", na versão de Janeira:

Sobre dez mil léguas de montanha

Os longos lençóis de nuvens

De súbito se entreabrem

A chuva para e agora

A lua aparece no céu claro.

Chegou a primavera aos pinheirais de Miho.

A névoa matinal se enreda ao marulhar das ondas.

(...)

Final:

Na décima quinta noite

Atingiu o símbolo da Perfeição

Irradiando na sua luz

O esplendor da sabedoria

Os votos estão cumpridos

E o país solidamente fundado e em paz

Rico dos sete tesouros

Que por favor da dança sagrada

Caíram sobre a terra.

Mas eis que as horas passaram

E o manto de penas flutua,

Primeiro sobre os pinheirais de Miho,

Depois sobre as nuvens das Ilhas Flutuantes,

Sobre o monte de Ashitaka

E sobre o cimo esfumado do Monte Fuji,

Torna-se indistinto

No espaço do céu azul

E da vista se perde.

(in JANEIRA, 1954: 34)

O texto de Janeira, menos brilhante que o de Haroldo de Campos, permite, por outro lado, que o ator / cantor tenha mais possibilidades interpretativas, de acordo com a modulação da voz. A declamação do nô, conforme vimos, é um tipo de "canto falado"(sprechgesang) em que a base está no ritmo, no deslocamento e entonação de frases e palavras, de acordo com a intenção dramática; Zeami, em seus tratados sobre o nô, dedica especial atenção às técnicas de voz, para a correta harmonização do texto, ritmo e melodia. “A alteração das palavras e do acento que, quando é bem executada, se 
torna uma técnica eficaz para gerar os efeitos artísticos, constitui o tema do capítulo X"

escreve Sakae M. Giroux, no livro Zeami: cena e pensamento nô (Giroux, 2012: 277),

referindo-se a um dos tratados de interpretação de Zeami. Em outra passagem, afirma:

Por outro lado, o efeito que se desprende do ritmo é essencial para Zeami. Em certas peças, como Hanagatami ("O Cesto de Flor") que ele mesmo redigiu, considera que as passagens referentes à mulher louca devem ser cantadas energicamente, do contrário, corre-se o risco de prejudicar a representação. Mas esse ritmo enérgico deve também ser submetido a algumas transformações, a fim de se romper a monotonia como, por exemplo, a execução de uma pausa abrupta sobre o sase de iwarasase.

Na peça Sumidagawa, "O rio Sumida", atribuída a Motomasa, Zeami recomenda uma diminuição do ritmo na passagem de um verso a outro, para obter um efeito de abundância na passagem citada no Sarugaku dangi. E para criar um efeito de ritmo, recomenda pronunciar com muita suavidade uma parte da palavra para, em seguida, articular claramente a outra.

Zeami mostra através de trecho da peça Shôkun, atribuída a Konparu Gonnokami, tio de Zenchiku, as transformações que o ritmo exige do idioma, como o da partícula funcional que se junta à primeira palavra da frase seguinte, o que seria inadmissível na prática corrente da língua. (Idem, 278)

A tradução de Janeira, clara e precisa, sem virtuosismo semântico, permite ao ator realizar plenamente as intenções de Zeami - sugerir, a partir da voz do ator, toda a multíplice gama de variações rítmico-dramáticas que fazem do nô uma verdadeira ópera de câmara, em que todos elementos visuais e sonoros constituem uma unidade estética. 


\subsection{Casimiro de Brito: o "rigor e a claridade enigmática do pensamento"}

Casimiro de Brito será o principal divulgador da poesia japonesa em Portugal na segunda metade do século XX, desenvolvendo amplo trabalho tradutório e ensaístico, além de organizar importantes antologias e publicar os seus próprios haicais, dialogando de maneira pessoal e inventiva com essa modalidade poética, incorporando temas e recursos pouco usuais na poesia japonesa tradicional, conforme discutiremos no presente tópico. Para termos uma compreensão do significado do trabalho de divulgação do haicai por Casimiro de Brito no cenário literário de Portugal é importante ressaltar que a poesia portuguesa, desde as primeiras décadas do século $\mathrm{XX}$ até os grupos que se articularam em torno de revistas como Presença, Árvore e Prisma, não assimilou qualquer influência da poesia japonesa, apesar das traduções pioneiras realizadas por Wenceslau de Moraes, que comentamos no capítulo anterior. Os poetas ligados à revista Orpheu - Fernando Pessoa, Mário de Sá-Carneiro, Almada Negreiros - dialogaram com a poesia clássica grega e romana, com a lírica elisabeteana, com a poesia simbolista francesa, Walt Whitman, o futurismo europeu, mas em nenhum momento com a arte concentrada de Matsuo Bashô e seus discípulos. A ausência de diálogo criativo com a poesia japonesa nas letras portuguesas nesse longo período é um caso excêntrico, uma vez que os leitores europeus e norte-americanos já entraram em contato com o haicai e a cultura japonesa muito tempo antes. Conforme escreve Octavio Paz:

Na história das paixões do Ocidente pelas outras civilizações há dois momentos de fascínio diante do Japão, se esquecermos o engouement dos jesuítas no século XVII e o dos filósofos no século XVIII: um se inicia em França em fins do século passado e, após fecundar diversos pintores extraordinários, culmina com o Imagism dos poetas anglo-americanos; outro começa nos Estados Unidos alguns anos depois da Segunda Guerra Mundial e ainda não terminou. O primeiro período foi, antes de tudo, estético; o encontro entre a sensibilidade ocidental e a arte japonesa produziu várias obras notáveis, tanto na esfera da pintura - e o exemplo maior é o impressionismo - como na da linguagem: Pound, Yeats, Claudel, Éluard. No segundo período a tonalidade tem sido menos estética e mais espiritual ou moral; isto é, não só nos apaixonam as formas artísticas japonesas como também as correntes religiosas, filosóficas ou intelectuais de que são expressão, em particular o budismo. (PAZ, 1996: 171) 
Uma das principais referências desse diálogo "entre a sensibilidade ocidental e a arte japonesa" a que se refere Octavio Paz é a publicação, em 1902, do livro Bashô and the japanese poetical epigram, de autoria do estudioso britânico Basil Chamberlain. Quatro anos depois, o orientalista francês Paul-Louis Couchoud publica na revista Les lettres dois importantes ensaios: Les haikai e Les épigrammes lyriques du Japon, esse último acompanhado de cerca de cem haicais traduzidos, possivelmente a partir do inglês. Conforme diz Paulo Franchetti, o segundo ensaio de Couchoud foi republicado no volume Sages et poetes d'Asie, em 1916, e o livro "correu o mundo, precedido de um prefácio de Anatole France, tornando-se uma das principais referências sobre o assunto, para os leitores de formação francesa" (FRANCHETTI: 2012, 200). Nesse mesmo ano, Julien Vocance (nome literário de Joseph Seguin) publica uma coletânea de haicais intitulada Cent visions de guerre, e em 1921 "sistematiza as suas ideias sobre o haicai e o seu papel de exemplo de uma nova arte poética. Trata-se de Art poétique, que saiu na revista La connaissance" (idem, 201). Apesar da contribuição dos estudos de autores franceses e britânicos sobre o haicai e a cultura japonesa, foi graças ao norte-americano Ezra Pound que "a poesia japonesa passou a ser uma referência realmente importante no Ocidente" (idem, 44), escreve Paulo Franchetti. O autor dos Cantos "fará da reflexão sobre a poesia chinesa e japonesa um dos pontos centrais da sua influente concepção de poesia e literatura" (idem). Na obra teórica e ensaística de Ezra Pound, "a poesia do Extremo Oriente não vai ser nem uma preocupação lateral de um grande poeta (esse era o caso de Camilo Pessanha), nem uma referência importante de um poeta sem nenhuma influência duradoura (como se dá com Amy Lowell, por exemplo)" (idem). Pound descobriu o haicai e as peças de teatro nô a partir de seu interesse pela escrita e poesia chinesas - ele foi o editor do livro Os caracteres da escrita chinesa como instrumento para a poesia, de Ernst Fenollosa, que leu pela primeira vez em 1913, quando recebeu 
os originais que lhe foram entregues pela viúva do sinólogo. Nesta obra singular, "os caracteres chineses eram entendidos radicalmente como ideogramas, isto é, sinais que mantêm uma relação muito próxima com o objeto, ação ou propriedade que representam" (idem, 41). Pound irá valorizar, sobretudo, a justaposição de imagens no ideograma, "em que a relação entre as partes é de natureza metafórica" (idem, 42), recurso que utilizou na concepção estrutural de seu poema longo Os cantos (ou Cantares $^{108}$ ), que escreveu entre 1917 e 1949, no qual inseriu também personagens e episódios reais e lendários da cultura chinesa e japonesa, mesclados a citações enciclopédicas da literatura, da história e da mitologia de diferentes culturas ocidentais, constituindo, segundo Haroldo de Campos, um "imenso ideograma da cosmovisão poundiana, irredutível a um desenvolvimento tradicional, de progressão linear, sob o esquema princípio-meio fim" (CAMPOS, 1977: 58).

Ezra Pound foi o "inventor da poesia japonesa" para o nosso tempo, escreve Paulo Franchetti (parodiando a célebre frase de T. S. Eliot), porque "a desvinculou de uma vez para sempre das leituras que a reduziam a um exotismo sentimental e afetado, sem nenhum interesse para a poesia do Ocidente" (idem, 47), ao mesmo tempo que investiu na assimilação de elementos da estética chinesa e japonesa em seu próprio trabalho poético (e recordemos aqui o poema Numa estação de metrô, um quase haicai em que não faltam o signo da estação do ano e o flash de uma cena cotidiana, assim traduzido por Augusto de Campos: "A visão destas faces dentre a turba: / Pétalas num ramo úmido, escuro ${ }^{109, ", ~ e ~ a i n d a ~ o ~ e n i g m a ́ t i c o ~ t e r c e t o ~ P a p y r u s, ~ t a m b e ́ m ~ r e c r i a d o ~ p o r ~ C a m p o s: ~}$

\footnotetext{
108 No livro A arte no horizonte do provável, Haroldo de Campos afirma: "a própria armadura ideogrâmica dos Cantos, numa escala macroscópica, guarda analogia com a estrutura básica de superposição de elementos do haicai. Em 1914, visualizando o que seria um longo poema imagista ou vorticista, escreveu Pound: 'Perguntam-me, frequentemente, se poderia haver um poema longo imagista ou vorticista. Os japoneses, que produziram o haicai, produziram também as peças Nô. No melhor Nô, a peça inteira... é reunida em torno de uma imagem... Nada tenho contra um longo poema vorticista" (CAMPOS, 1977: 57).
}

${ }^{109}$ POUND, 1983: 93. 
“Domingo / Tão longo / Gôngula ${ }^{110 »)}$. Earl Roy Minner, em texto publicado na revista de estudos Pound Newsletter, chega a afirmar que "enquanto o seu débito para com a China consiste principalmente em ideias históricas, éticas, políticas e outras, sua dívida para com o Japão é mais importante do ponto de vista de sua teoria literária e de sua técnica" (in CAMPOS, 1977: 57). Ao lado de Pound, outra referência que precisa ser citada é a do escritor norte-americano Reginald Horace Blyth, autor da importante antologia Haiku, obra em quatro volumes com traduções de poemas de Bashô, Issa, Buson, Shiki e outros poetas menos conhecidos no Ocidente. Segundo Paulo Franchetti, "suas traduções e comentários aos haicai, aos senryu" e aos textos zen são de valor inestimável para todo estudioso da literatura japonesa no Ocidente." (idem). Ele conhecia profundamente "não só a literatura japonesa como ainda a chinesa e a coreana, e sua familiaridade com os poetas de língua inglesa era também invejável" (idem). Blyth tornou-se um ícone da cultura pop nas décadas de 1950 e 1960, contribuindo para a divulgação da estética e da espiritualidade japonesa, ao lado de autores como D. T. Suzuki e Allan Watts, que foram essenciais para a formação de poetas como Allen Ginsberg, Gary Snyder e Jack Kerouac. Todo esse rico diálogo entre a cultura japonesa e o Ocidente, no entanto, só frutificaria no cenário poético português no final da década de 1950, quando Casimiro de Brito (nascido em 1938), em viagem de estudos na Inglaterra, entrou em contato com o haicai. Em depoimento publicado na edição XXVI da revista Zunái, o poeta português afirma:

\footnotetext{
${ }^{110}$ Idem, 96. Este poema, datado de 1916, é uma "transfiguração fônica" (...) dos resíduos de um fragmento sáfico, recuperados e tentativamente reconstruídos por dois helenistas, um alemão, outro inglês, e a seguir partilhados com júbilo inventivo por jovens poetas frequentadores da biblioteca do British Museum", conforme Haroldo de Campos (CAMPOS: 2013, 31). O poema de EP é portanto uma releitura-palimpsesto, quase heteronímia, em que Pound adota a persona e o timbre da poeta de Lesbos.

${ }^{111}$ O senryu (川柳, literalmente, "salgueiro do rio") é um gênero poético japonês semelhante ao haicai, dividido em três versos, somando 17 sílabas, mas sem o signo da estação do ano (o kigo) e de caráter irônico ou cínico, não raro aproximando-se do humor negro.
} 
Em 1958, numa espécie de exílio político (para me libertar do eminente recrutamento para a Guerra Colonial), fui para Londres e freqüentei o Westfield College. Era um curso de verão, organizado pela BBC, e coube-me ficar instalado nos aposentos de um professor de Poesia Oriental. Foi um deslumbramento - estar dentro de uma pequena biblioteca de poesia que eu desconhecia. E os livros de haiku deslumbraram-me. Na Universidade havia alunos de mais de 50 países e, entre eles, uma japonesa. Aproximei-me dela, contei-lhe quem era e ao que vinha: que ela me ajudasse a traduzir alguns daqueles poetas já que algumas das traduções inglesas não me agradavam. Disse-me que sim, e foram semanas, meses de trabalho delicado e quase abençoado; foi uma relação amorosa iluminada pela poesia. Quando regressei a Portugal a minha poesia transformou-se noutro mundo porque não só se desenvolvia na tradução dos famosos mestres japoneses como eu próprio comecei a escrever de outra maneira. (in Zunái, Revista de Poesia e Debates n. XXVI, março de 2013)

Fascinado pela condensação poética do haicai, sua economia verbal, sutileza e ironia, o poeta português desenvolve atividades de estudo e tradução da poesia japonesa, além de escrever, ele próprio, composições na forma do terceto e de organizar antologias com trabalhos de outros autores portugueses que se dedicaram às formas do tanka e do haicai, de modo ocasional ou sistemático (Uma rã que salta-Homenagem a Bashô. Porto: Limiar, 1995). Seu trabalho no campo da tradução (realizado em parceria com Natsuishi Ban’Ya, professor de francês na Universidade de Tóquio), acompanhado de estudos críticos, está reunido em duas publicações: Poemas orientais, pequeno volume editado em 1962, na cidade de Faro, e o caderno Poesia japonesa, separata da revista de poesia Limiar n. 5, editada no Porto, que saiu em 1995. As traduções de Casimiro de Brito diferenciam-se daquelas realizadas por Wenceslau de Moraes na década de 1920 por não serem meros registros literais, não raro com adições explicativas ou decorativas ausentes nos textos originais, o que aliás também verificamos nas traduções que Jorge de Sena realizou de Bashô e publicadas em sua monumental antologia Poesia de 26 séculos, das quais citamos, como amostragem, sua versão para o poema da rã: “Quebrando o silêncio / do charco antigo a rã salta / n'água - ressoar fundo"112 (in SENA, 1972: 11). Casimiro de Brito, ao contrário de seus

\footnotetext{
${ }^{112}$ Jorge de Sena escreve o seguinte comentário sobre a poesia de Bashô, em sua antologia Poesia de 26 séculos: "A poesia de Bashô é capaz de uma concentração extraordinária; capaz de, nos estreitos limites do haicai, incluir toda a gama da sensibilidade humana, num estilo que não se abandona nunca à
} 
ilustres predecessores, busca conservar não apenas a informação semântica mas também a simplicidade e a coloquialidade do haicai tradicional, e sobretudo o estilo conciso, por vezes seco e abrupto dos textos japoneses, como nesta curiosa composição: "Narciso e biombo: / iluminam-se, branco / no branco, um ao outro ${ }^{113 "}$ (Bashô, 1644-1694), que podemos comparar com versão similar feita por Paulo Leminski: "narciso / biombo / um ao outro ilumina / branco no branco"114, e ainda com a versão de Jorge de Sena: "Um branco narciso / E um branco biombo se reflectem / na sala quieta" (in SENA, 1972: 12). A abstração deste poema, que já foi comparado com a pintura de um artista europeu de vanguarda como o suprematista soviético Casimir Maliévitch, contrasta com a delicadeza de outra composição, quase uma fotografia do cotidiano: "Mulher sem filhos - / como ela é terna / com as bonecas! ${ }^{115 "}$ (Ransetsu, 1654-1707). A metáfora comparece de maneira inusitada nesta peça: "Mulheres no arrozal - / tudo nelas é sujo / menos o seu canto ${ }^{116 "}$ (Raizan, 1654-1716), e ainda neste poema de refinada construção imagética: "O vento, no outono, / toma a forma do capim, / tão espesso! ${ }^{117 "}$ (Kigin, 1624-1704). A participação do eu poético, raridade em uma escrita poética tão

sentimentalidade, e é de uma capacidade descritiva admirável, com por vezes uma aguda e muito realista ironia. O haicai é, na sua forma clássica, um poema de três versos, respectivamente de 5-7-5 sílabas. Outras variações, de ordem daqueles números de sílabas, ou de transformação de um dos valores no outro, eram permitidas. Nas traduções, respeitamos rigorosamente o número de sílabas que Bashô usa em cada verso (não contando, como se deve na metrificação portuguesa, as sílabas depois da última tônica) dos seus haicais. Anote-se que bashô significa banana, e é nome adotado pelo poeta, em homenagem irônica à bananeira que havia em frente à porta de sua casa." (SENA, 1972: 131-132).

${ }^{113}$ In BRITO, 1995: 13.

${ }^{114}$ Branco no branco (1984), livro de poemas de Eugênio de Andrade, teve o seu título inspirado neste haiku de Bashô.

${ }^{115}$ In BRITO, 1995: 13.

${ }^{116}$ Idem.

${ }^{117}$ Idem, 12. 
impessoal, está registrada nesta composição, associada a outra metáfora: "A cobrir os milênios / da minha ausência / o véu duma cascata ${ }^{118 ”, ~(N a t s u i s h i ~ B a n ’ Y a, ~ 1955) . ~}$

Casimiro de Brito obtém resultados poéticos consistentes em português, evitando a afetação e o exotismo, tipo rice powder poetry, males citados por Haroldo de Campos em sua crítica às traduções de poesia oriental filtradas por um simbolismo finissecular. Ao mesmo tempo que evitava os clichês associados a uma ideia romântica de "Oriente", Casimiro de Brito não intentou uma recriação radical da estrutura do ideograma, aquilo que Haroldo de Campos chamava de "metáfora visual" e que é inseparável tanto da escrita como do pensamento japonês. A dimensão plástica dessa micropoética altamente condensada permite-lhe "um extremo refinamento de percepção, um grande poder de síntese imaginativa, em consonância, aliás, com o espírito poético japonês" (CAMPOS: 1977, 65), afirma o poeta e ensaísta brasileiro, citando como exemplo a palavra yumê ("sonho" em japonês), "expressa pelos desenhos abreviados, superpostos, de vegetação crescendo + rede de pesca + cobertura + sol-pôr" (idem, 64). É impossível deixar de pensar "nos estímulos que este simples vocábulo, a partir de seu casulo gráfico, oferece à imaginação poética. É ele, por si só, um verdadeiro diorama de estratos metafóricos" (idem). "No pensamento por imagens do poeta japonês", prossegue o autor brasileiro, “o haicai funciona como uma espécie de objetiva portátil, apta a captar a realidade circundante e o mundo interior, e a convertê-los em matéria visível” (idem, 65).

Casimiro de Brito desconsidera a dimensão visual da escrita e os jogos polissêmicos do kakekotoba em sua recriação da poesia japonesa para o nosso idioma, mas mantém a alta precisão, a dicção enxuta e substantiva do verso japonês, sua simplicidade e espontaneidade, características de todas as artes tradicionais influenciadas pelo zen. A naturalidade da própria caligrafia japonesa, que incorpora o

${ }^{118}$ Idem, 17. 
traçado rápido, o borrão e os contornos assimétricos e imprecisos, dificilmente poderia ser recriada em um método de tradução que valoriza o controle do acaso e o rigoroso cálculo prévio dos efeitos. Neste sentido, podemos considerar válida a observação de Paulo Franchetti, para quem esse método leva a um afastamento "do contexto de produção e recepção, bem como da função social de um dado texto em uma dada sociedade", privilegiando as "correspondências sintáticas, semânticas e sonoras" (FRANCHETTI, 2012: 49). “Quando o poema a ser traduzido pertence a um universo de referências próximo a essa visão de literatura, o método tem resultados excelentes, como se pode ver na tradução que Haroldo de Campos fez do Un coup de dés, de Mallarmé" (idem), prossegue Paulo Franchetti, fazendo a ressalva que "na leitura do haicai, no entanto, que provém de um outro universo de referências, esses pressupostos têm mais efeitos nocivos do que positivos" (idem, 50), citando como exemplo a tradução que Haroldo de Campos fez do famoso poema da rã, de Bashô:

o velho tanque

rã salt’

tomba

rumor de água

(CAMPOS, 1977:62)

$\mathrm{Na}$ opinião de Paulo Franchetti, "em face da poética de Bashô, que sempre demonstrou aversão à mera exibição técnica em haicai (...), a utilização de uma 'palavra-valise' à James Joyce parece completamente inadequada" (idem, 51). O autor justifica seu severo parecer argumentando que "o hokku de Bashô, célebre por inaugurar a maneira despojada e não simbólica de uma escola que se dizia acessível a crianças e incultos, converte-se em um precioso micropoema ostensivamente trabalhado com agudeza e engenho" (idem, 51) (observemos aqui o uso de palavras extraídas do vocabulário barroco, com intenção crítica; os grifos são meus). O parecer de Paulo 
Franchetti leva em consideração o contexto histórico e cultural em que a poesia japonesa foi produzida e também sua legibilidade na época atual, ou seja, ele reconhece a relevância do receptor e do sentido, e é neste ponto que podemos fazer uma breve discussão sobre a poética da tradução. Conforme diz o filósofo alemão Walter Benjamin no ensaio A tarefa do tradutor, escrito em 1921, "levar em consideração o receptor de uma obra de arte ou de uma forma artística" em hipótese alguma "revela-se fecundo para o seu conhecimento" (BENJAMIN, 2011: 101), uma vez que "o próprio conceito de um receptor 'ideal' é nefasto em quaisquer indagações de caráter estético, porque estas devem pressupor unicamente a existência e a essência do homem em geral" (idem). Numa obra poética, continua o autor, "o que lhe é essencial não é comunicável, não é enunciado" (idem, 102), motivo pelo qual a tradução literal seria a "transmissão inexata de um conteúdo inessencial" (idem). Aquilo que realmente importa num poema, para Walter Benjamin, é “o inapreensível, o misterioso" (idem), cabendo ao tradutor a tarefa de encontrar, em seu próprio idioma, um eco "capaz de reproduzir (...) a ressonância de uma obra estrangeira" (idem, 112), tal como fez Hoelderlin em suas versões das tragédias de Sófocles, ou ainda Voss com as traduções de Homero e Lutero com a Bíblia, reconhecendo porém que "toda tradução é apenas um modo algo provisório de lidar com a estranheza das línguas", permanecendo "vedada aos homens (...) uma solução não-temporal e provisória para essa estranheza, uma solução instantânea e definitiva" (idem, 110). O filósofo alemão conclui o seu ensaio fazendo uma longa citação de Rudolf Pannwitz, para quem “o erro fundamental de quem traduz é conservar o estado fortuito da sua própria língua, ao invés de deixar-se abalar violentamente pela língua estrangeira" (idem, 118). O autor considera que, "sobretudo quando traduz de uma língua muito distante, ele deve remontar aos elementos últimos da língua mesma, onde palavra, imagem e som se tornam um só. Ele tem de ampliar e aprofundar sua 
língua por meio da língua estrangeira" (idem). As teses defendidas por Benjamin e Pannwitz encontram ressonância nas formulações teóricas de Haroldo de Campos, para quem a tradução é "recriação, ou criação paralela, autônoma, porém recíproca", conforme escreve em ensaio publicado no livro Metalinguagem e outras metas (CAMPOS: 2004, 35). “Quanto mais inçado de dificuldades esse texto, mais recriável”, prossegue Haroldo de Campos. Numa tradução dessa natureza, "não se traduz apenas o significado, traduz-se o próprio signo, ou seja, sua fisicalidade, sua materialidade mesma (propriedades sonoras, de imagética visual, enfim, tudo aquilo que forma, segundo Charles Morris, a icoinicidade do signo estético)" (CAMPOS, 2004: 35). O significado, ou "parâmetro semântico", conclui o autor, "será apenas e tão-somente a baliza demarcatória do lugar da empresa recriadora. Está-se pois no avesso da chamada tradução literal" (idem). A tradução de poesia, de acordo com esse pensamento, seria, antes de tudo, "uma vivência interior do mundo e da técnica do traduzido. Como que se desmonta e se remonta a máquina da criação, aquela fragílima beleza aparentemente intangível que nos oferece o produto acabado numa língua estranha” (idem, 43). Nessa operação de linguagem, o tradutor realizaria uma "vivissecção implacável, que lhe revolve as entranhas, para trazê-la novamente à luz num corpo linguístico diverso" (idem, 43), princípio que orientou as traduções criativas que Haroldo de Campos realizou de poemas bíblicos, como o Qohélet e o Bereshit, contaminando o português com a sintaxe e a semântica do hebraico, construindo uma língua híbrida, assim como "russificou" o português em suas recriações de Maiakovski e "niponizou" o idioma em sua versão de Hagoromo, peça de teatro nô escrita por Zeami no século XIV, além de haicais de Bashô e Buson. A estratégia de leitura e transcriação adotada por Haroldo de Campos obteve resultados extraordinários, do ponto de vista da construção formal, mas a ressalva apresentada por Paulo Franchetti permanece válida; como resolver o impasse 
entre a recriação e o espírito de despojamento da filosofia zen-budista? Temos aqui um caso para a liberdade de escolha do tradutor, que pode adotar o método que encontrar correspondência com a sua visão particular sobre a poesia e a literatura, uma vez que nenhuma tradução será perfeitamente exata ou inexata, em especial quando se trata do haicai, com todas as suas camadas de significação, tanto semânticas quanto históricas e culturais, muitas delas intraduzíveis. A operação tradutória, tal como a entendemos, não busca uma verdade unívoca, mas a relação estética e de pensamento entre o tradutor e o texto traduzido. Karlheinz Stierle faz uma interessante observação sobre a recepção de textos de outras épocas e culturas pela sensibilidade e compreensão de nosso tempo que merece ser reproduzida aqui:

O leitor não contemporâneo é por isso obrigado, não só a estabelecer uma relação com o texto, mas ao mesmo tempo a reconstruir os repertórios de que dispunha o receptor da comunicação original. No entanto, esta reconstrução nunca pode reconstituir o horizonte original da experiência; ela não passa de relativa e particular, pois é possibilitada por uma conceitualidade explícita. Mas a extinção do contexto da experiência original não tem apenas um aspecto negativo. À medida que reduz os efeitos peculiares das significações conotativas, remete para a conceitualidade essencial do texto, desse modo, dirige especialmente a recepção quase pragmática, criadora de ilusão, para a própria ficção. A diferença temporal entre a produção e a recepção faz com que se perca o encanto dos estereótipos da experiência, trazidos pela própria recepção, e isso permite que se patenteie, sob a qualidade quase pragmática, a qualidade ficcional do texto. (In LIMA: 2011, 157)

Em outra passagem do mesmo ensaio, o autor afirma: "nenhum texto diz apenas aquilo que desejava dizer. Cada texto sofre a coerção inevitável de produzir uma comunicação suplementar e não prevista" (in LIMA: 2011, 131), o que atribui à recepção um evidente caráter lúdico, e nos faz pensar nas concepções de Wolfgang Iser, expostas no ensaio $O$ jogo do texto: "Os autores jogam com os leitores e o texto é o campo do jogo. O próprio texto é um ato intencional pelo qual um autor se refere e intervém em um mundo existente, mas, conquanto o ato seja intencional, visa a algo que ainda não é acessível à consciência" (in LIMA, 2011: 107). Isto ocorre, segundo o teórico alemão, porque "o texto é composto por um mundo que ainda há de ser identificado e que é esboçado de 
modo a incitar o leitor a imaginá-lo e, por fim, interpretá-lo" (idem). "Essa dupla operação de imaginar e interpretar", prossegue o autor, "faz com que o leitor se empenhe na tarefa de vislumbrar as muitas formas possíveis do mundo identificável, de modo que, inevitavelmente, o mundo repetido no texto começa a sofrer modificações" (idem). A conclusão dessa premissa, para Iser, é que "não importa que novas formas o leitor traz à vida: todas elas transgridem - e, daí, modificam - o mundo referencial contido no texto" (idem). A modificação do campo referencial na recepção, conforme Karlheinz Stierle, pode ser sintetizada nesta afirmação - que pode ser invocada em defesa da recriação haroldiana: “a relação do texto com a realidade não é uma simples função de uma realidade a ser retratada, mas sim de uma poética da ficção, que pode ser ora mais, ora menos relacionada com a realidade e com a experiência coletiva da realidade" (idem, 131). Estabelecendo uma diferença entre os textos pragmáticos e os ficcionais, Stierle afirma que estes últimos "são, no sentido próprio, textos de ficção apenas quando se pode contar com a possibilidade de um desvio do dado, desvio na verdade não sujeito a correção, mas apenas interpretável ou criticável” (idem, 132). O desvio do dado original é possível pelo "preenchimento dos vazios e das indeterminações produzidas pelo texto, das quais se apodera a capacidade imaginativa do leitor" (idem, 157), resultando no fato de que, na experiência do texto ficcional, ocorra "o processo de formação da ilusão e da quebra da ilusão, em que se constituem e questionam figuras de sentido sempre novas", de modo que, para o autor alemão, "a produtividade constituinte do leitor, proveniente das indeterminações, se experimenta a si própria e, ao mesmo tempo, à resistência de uma realidade textual, que se mostra por perspectivas sempre novas e na história das diferenças destas perspectivas” (idem). O próprio Casimiro de Brito, no prefácio aos Poemas orientais, diz: “A poesia é intraduzível, e a minha tentativa de verter para o português, de fazer poesia a partir dos 
haicais japoneses, sem lhes roubar a magia, o clímax oriental é, reconheço-o, demasiado arriscada" (BRITO, 1962: 10). Em consequência, "penitencio-me dizendo que foi uma tentação, e considero estes poemas breves um pouco como poesia minha” (idem).

A ideia da tradução poética como novo texto original, em condições de igualdade com os poemas escritos pelo próprio poeta/tradutor, não é nova: ela deriva dos ensaios teóricos e da prática criativa de Ezra Pound, que em seu poema longo Os cantos inseriu textos traduzidos da Odisseia, de canções dos trovadores da Idade Média, entre outros, de diferentes momentos históricos e países, mesclados aos versos de sua própria lavra, sem nenhuma sinalização prévia para o leitor sobre os créditos de cada composição. O autor norte-americano considerava a tradução como persona (máscara dramática), que lhe permitia falar pela voz de grandes poetas do passado, como François Villon, Guido Cavalcanti e Artaud Daniel, e ainda de Li T'ai Po (Rikaku, em japonês) e Zeami. Ao lado da ideia da tradução como um tipo de heteronímia (tese formulada por Adolfo Casais Monteiro ${ }^{119}$ ), Ezra Pound desenvolveu o conceito da crítica pelo exercício no estilo de uma época - ou seja, o poeta passou a escrever poemas usando a linguagem e os recursos formais de autores da Idade Média ou do Renascimento, como forma de aprendizado e de diálogo com a tradição, visando realçar elementos poéticos pouco conhecidos nos dias de hoje. $\mathrm{O}$ autor norte-americano não desejava fazer de seu trabalho ensaístico e crítico-criativo uma mera arqueologia do passado literário, e sim descobrir, dentro da tradição, o que ainda era novo, ou pouco assimilado, fiel ao princípio confuciano do Make it new, que adotou como palavra-de-ordem. Quando Casimiro de Brito fala em "fazer poesia a partir dos haicais japoneses" ele apresenta uma proposta-

119 Na opinião de Augusto de Campos: "O paralelo é, sem dúvida, instigante. Mas o exame em profundidade dos dois artifícios revela atitudes poéticas diversas. As personae de Pessoa são, na verdade, personalidades fictícias projetadas do próprio poeta, de dentro para fora. (...) Já as máscaras de Pound correspondem (com exceção talvez única de Mauberley) a pessoas reais de poetas que falam, em sua própria linguagem, 'através de' Pound: Cino, Bertran de Born, Villon, Heine, Laforgue, Corbière etc." (CAMPOS, 1983: 25) 
desafio similar à do autor norte-americano, analogia que ganha força quando pensamos que o poeta português, assim como Ezra Pound, exercitou-se na criação conforme o estilo de uma época, nos haicais de sua própria autoria.

Para termos uma ideia do rigor com que Casimiro de Brito trabalhou em suas traduções, vamos comparar algumas peças que comparecem nas duas antologias, Poemas orientais (1962) e Poesia japonesa (1995), em diferentes versões:

A vida? Simples borboleta agitando-se na relva...

Como ela é delicada!

$\operatorname{SOIN}^{120}$

(Poemas orientais)

Visita às sepulturas...

Correndo, a mostrar o caminho, o velho cão da família.

ISSA $^{122}$

(Poemas orientais)

Oh estúpido espantalho!

Debaixo das tuas pernas de pau os pássaros estão roubando favas... YAYU $^{124}$

(Poemas orientais)
A vida? Borboleta agitando-se na relva Tão delicada!

SOIN $^{121}$

(Poesia japonesa)

Visita ao cemitério. O velho cão de família ensina o caminho

ISSA $^{123}$

(Poesia japonesa)

Pobre espantalho!

Os pássaros roubam favas sob os seus pés de pau YAYU $^{125}$

(Poesia japonesa)

Nas traduções incluídas no volume Poemas orientais (1962), notamos versos mais longos, de sintaxe regular, próxima ao ritmo da prosa. Já nas composições compiladas

\footnotetext{
${ }^{120}$ BRITO, 1995: 13.

${ }^{121}$ BRITO, 1962: 12.

${ }^{122}$ BRITO, 1995: 28.

${ }^{123}$ BRITO, 1962: 16

${ }^{124}$ BRITO, 1995: 21.
} 
em Poesia japonesa (1995) há maior concisão, cortes sintáticos e ritmo mais seco, que reforçam o poder de impacto da imagem poética. Os elementos temáticos e formais desse conjunto de traduções serão incorporados e transformados na poesia do próprio Casimiro de Brito, que realiza uma notável mescla do imaginário tradicional japonês com uma sensibilidade moderna temperada pelas vanguardas europeias, que reivindicavam a síntese, a concisão, a ruptura com a lógica sintático-discursiva, a visualidade e o pensamento analógico (lembremos que Casimiro de Brito integrou um dos movimentos de renovação da poesia portuguesa, o chamado Poesia 61, ao lado de Fiama Hasse Pais Brandão, Luiza Neto Jorge, Maria Tereza Horta e Gastão Cruz, aliás contemporâneo da $P O-E X$, liderado por Ana Hatherly e E. M. de Melo e Castro. Ao contrário dos experimentalistas, porém, a Poesia 61 não investiu na poesia visual, concentrando-se na pesquisa criativa do poema-texto, que se desenvolve na dimensão temporal, não na espacial). Todos esses elementos construtivos estão presentes no ambicioso projeto que Casimiro de Brito denominou LIVRO DOS HAIKU, obra em progresso desenvolvida desde 1958 que será constituída de 14 livros, sendo que apenas dois foram publicados até a presente data: 1) À sombra de Bashô (renga que intercala haicais traduzidos do poeta japonês com outros de autoria do próprio Casimiro de Brito); 2) renga com Ban'Ya; 3) (Elementos, estações); 4) Eros mínimo; 5) Devastação; 6) Da comoção; 7) Através do ar (editado no Japão, em quatro línguas, em parceria com Ban’Ya); 8) Amando, escrevendo; 9) Para além; 10) Outras músicas; 11) Desprendimento; 12) No amor tudo se move; 13 e 14) antologias de haikus antigos e contemporâneos. O primeiro livro deste ciclo, À sombra de Bashô, uma elegante publicação em formato vertical e textura roxa na capa e contracapa, de $14,5 \mathrm{~cm}$ por $35 \mathrm{~cm}$, é um conjunto de 110 poemas alinhados na forma de renga, gênero poético

\footnotetext{
${ }^{125}$ BRITO, 1962: 15.
} 
japonês em que dois ou mais poetas participam, intercalando os versos. Conforme escreve Shuichi Kato, "cada um faz uma estrofe relacionada exclusivamente à última estrofe composta, sem nenhuma necessidade de considerar as estrofes anteriores." (KATO, 2011: 94). "O fluir do renga não é planejado", afirma o autor japonês, "ele segue conforme as ideias que surgem no momento, ora mudando-se o tema, ora o cenário, ora a emotividade (idem)." Nessa forma de fazer poético regida pela mobilidade, casualidade e surpresa, sem uma unidade ou foco de interesse, o encanto reside no "encontro inesperado", na "engenhosidade" e na "retórica" de cada estrofe apresentada (idem). Em À sombra de Bashô há um elemento insólito adicional, que é o diálogo involuntário de um poeta-samurai japonês do século XVII com um autor português do século XX, que responde aos haicais de Bashô, traduzidos diretamente do idioma original e apresentados em itálico, com outros haicais, concebidos de maneira paródica (no sentido original da palavra, que em grego significa "canto dialogado"). Assim, o conhecido poema de Bashô "No velho tanque - / uma rã salta, mergulha - / ruído na água ${ }^{126 "}$ é seguido por esta composição de Casimiro de Brito: "Na página branca / na branca voz - outra rã / salta. Silêncio ${ }^{127,,}$, que introduz, sub-repticiamente, uma terceira voz na renga, a do simbolista francês Stéphane Mallarmé, representado por algumas de suas obsessões - o silêncio, a página em branco e o acaso. Outro poema de Bashô, "O mar escurece / ouço grasnar os patos / vagamente brancos ${ }^{128 "}$ recebe a seguinte resposta criativa de Casimiro de Brito: "Nuvem deitada / Os olhos espreitam o peixe / que vai saltar ${ }^{129}$,, em que a metáfora e o close cinematográfico de uma imagem inusitada respondem às sinestesias do poema anterior. Este haicai também foi traduzido

\footnotetext{
${ }^{126}$ In BRITO, 2001: 7.

${ }^{127}$ Idem.

${ }^{128}$ Idem, 11.
} 
por Jorge de Sena, na referida antologia Poesia de 26 séculos, do seguinte modo: "No

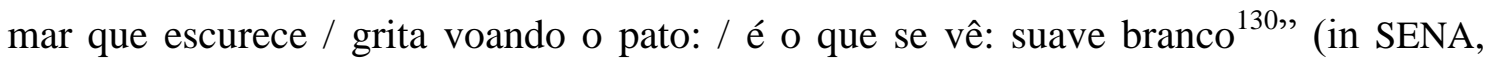
1972: 12), versão convencional que contrasta com a força elíptica e paratática da recriação de Paulo Leminski: "o mar escurece / a voz das gaivotas / quase branca" (LEMINSKI, 1983: 36).

O diálogo poético estabelecido por Casimiro de Brito com Matsuo Bashô não hesita em subverter o sentido dos poemas com os quais conversa, nem guarda pudores em relação a princípios do haicai tradicional, injetando o sensualismo (ausente na lírica do poeta samurai), metáforas complexas, citações metalinguísticas, a presença ostensiva do eu lírico e referências urbanas que denunciam o poeta como um cidadão da modernidade, em contraste com o mundo místico, simples e rural de um Japão que não mais existe (tornou-se literatura). Alguns exemplos da riqueza imagética das composições de Casimiro de Brito:

42

Aproximam-se as patas invisíveis do sol de sombras calçadas ${ }^{131}$.

58

O sol adormece

no seu lençol de nuvens

- insônia vermelha ${ }^{132}$.

60

As patas do sol aproximam-se, invisíveis,

${ }^{129}$ Idem.

${ }^{130}$ Em francês, o poema recebeu a seguinte de tradução de Roger Munier: "Sur la mer obscure / le cri blême / d'um carnard sauvage" (MUNIER, 2012: 54). Em espanhol, por sua vez, Octavio Paz traduziu da seguinte forma: "El mar ya oscuro: / los gritos de los patos / apenas blancos" (in PAZ, 1974: 241). Todas essas versões, bastante literais, são aproximadas às versões portuguesas e brasileiras.

${ }^{131}$ Idem, 13.

${ }^{132}$ Idem, 17. 
da relva do corpo ${ }^{133}$.

Cidade caótica -

a borboleta atravessa a rua

com o sinal vermelho ${ }^{134}$.

Podemos recordar, lendo estes poemas, de alguns haicais de Bashô que colocam em primeiro plano a imagem rara, como esta peça traduzida por Paulo Leminski : "chuva de primavera / a água escorre do teto / pelo ninho de vespas" (in LEMINSKI, 1983: 51), ou ainda: "relampagueia / através das trevas / a garça ecoa" (idem, 50). Bashô, samurai sem mestre (浪人; 浪, ronin) que tornou-se monge zen-budista, tematiza o amor universal, a compaixão por todos os seres vivos, de todos os gêneros e condições sociais, até mesmo pelas plantas e os insetos ("sob o mesmo teto / dormem rameiras, a lua / e também o trevo ${ }^{135}$ ", na tradução de Casimiro de Brito), mas nada fala sobre o amor erótico $^{136}$ (embora fosse contemporâneo dos Livros de primavera, romances pornográficos em voga na época, e dos rengas satíricos produzidos por comerciantes e soldados); já o poeta português elege esse tema como um dos pontos centrais de seu labor criativo, como podemos ler nesta composição de extrema sutileza e delicadeza:

\footnotetext{
${ }^{133}$ Idem.

${ }^{134}$ Idem, 19.
}

${ }^{135}$ In BRITO, 2001: 23. Na versão de Octavio Paz para o espanhol: "Bajo um mismo techo / dormieron las cortesanas, / la luna y el trébol” (in PAZ, 1974: 243).

136 A temática erótico-amorosa será mais frequente na poesia japonesa a partir da Restauração Meiji, destacando-se a produção de Yosano Akiko (1878-1942), autora de versos como estes, traduzidos por Donatella Natili e Álvaro Faleiros: "ouça o poema / como negar o carmim / da flor do campo? / delícias a menina / pecar na primavera" (in AKIKO, 2007: 53). Conforme Donatella Natili, "Akiko distinguiu-se desde o princípio como inovadora e portadora, em suas obras, de uma forte consciência feminista. Seus poemas, surgidos no momento em que se assistiu ao reflorescer do tanka, de inspiração romântica, ficaram famosos pela audácia e quebra de convenções, pela linguagem explícita e pelo uso informal da poética tradicional" (idem, 15). A poeta japonesa, segundo Donatella, "rompeu brutalmente com o estilo tradicional do tanka ao inserir questões pessoais e imagens não convencionais. Algumas expressões utilizadas chegaram a levar muitos literatos da época a reagir escandalizados. Por exemplo, a menção direta aos 'seios' femininos era considerada altamente ofensiva pelos leitores” (idem, 19-20). 
“Cabelos que vou pentear / a noite inteira. O vestido / junto à lareira ${ }^{137 ”}$. Em outros momentos da renga, Casimiro de Brito inclui haicais de caráter filosófico, como se fossem aforismos:

64

O mundo não vou mudar deixa-me sacudir a areia das tuas sandálias ${ }^{138}$.

90

A morte não existe.

Onde secam ervas foi água, que se partiu triste ${ }^{139}$.

102

Tanta luz feliz

Por tão pouco tempo! Amanhã

Estaremos velhos ${ }^{140}$.

110

Talvez a morte não

exista. Talvez seja apenas

viagem, flutuação ${ }^{141}$.

A afinidade entre o haicai e o aforismo foi percebida por Maria João Cantinho, que, na resenha do livro mais recente de Casimiro de Brito, A boca da fonte (Póvoa de Santa Iria: Lua de Marfim - Editora Unip. Lda., 2012), escreve: "A estética do haiku tem, ainda, vários pontos de afinidade com o aforismo, pela mesma retórica, pelo mesmo sentido de economia e de rigor poético", motivo pelo qual "tenha entrado na literatura ocidental pela estética do fragmento, tão cara aos poetas alemães românticos, tendo

\footnotetext{
${ }^{137}$ Idem, 15.

${ }^{138}$ Idem, 18.

${ }^{139}$ Idem, 22.

${ }^{140}$ Idem, 24.

${ }^{141}$ Idem, 26.
} 
como cultor máximo do gênero o poeta Novalis ${ }^{142 "}$ (CANTINHO, 2013). O aforismo e o fragmento estão presentes em diversas obras do autor português, relata a autora, citando livros como A arte da respiração, editado pela D. Quixote (1988), Da frágil sabedoria, (2001), Fragmentos de Babel (2007) e Arte de bem morrer (2007), aos quais podemos acrescentar $\mathrm{Na}$ via do mestre (2010), conjunto de 81 poemas-aforismos que dialogam com o Tao te king, do sábio taoísta chinês Lao Zi, que viveu no sexto século antes de Cristo. "A peculiaridade e o próprio sentido desta estética do fragmento nasce do próprio instante e da concentração temporal nele existente, do Aqui e do Agora que se abrem na sua leitura", escreve a autora (idem). O tempo do poema é o tempo presente; mesmo a recordação evocada de situações localizadas em outras coordenadas espaço-temporais se concretiza poeticamente a partir da rememoração / refabulação feita no agora. Ou ainda: o poema cria o seu próprio tempo, que se manifesta na duração da leitura, e o seu próprio espaço, que é o branco da página. Conforme diz Maria João Cantinho, "o poema conquista a sua plenitude à luz da organicidade e da estruturação que dele irradia, da sua própria concentração temporal e espacial”. Por essa razão, "cada poema deve ser lido ao centro, para que, da concentração do olhar, surja também a contemplação da origem e do fim do poema, da palavra e da coisa" (idem).

Partindo desses pressupostos, afirma a autora que "a estética do haiku ou do fragmento recusa a ideia de um acabamento ou de uma definição da obra e esta vai-se fazendo à medida que se escreve cada poema, definindo-se precisamente pela ausência da sua definição" (idem). Desse modo, a poesia concentrada colhe, em cada verso, "a imperfeição e o segredo, o inesperado" (idem). Os vetores conceituais apresentados por Maria João Cantinho em seu texto são instigantes pontos de partida para uma discussão do conjunto de cem haicais que Casimiro de Brito compilou em seu livro A boca da

\footnotetext{
${ }^{142}$ Casimiro de Brito: A boca na fonte, resenha publicado no n. XXVII da revista Zunái (março / 2013).
} 
fonte. A série não tem unidade temática, nem é dividida em focos de interesse; os poemas são numerados e alinhados em grupos de dois, quatro ou cinco por página, sem um critério de organização claramente identificável. Os haicais de Casimiro de Brito raramente têm rimas e a métrica não é sempre exata, embora esteja próxima das medidas japonesas, de 5-7-5 sílabas. O autor prescinde do signo da estação do ano, o kigo, mas investe na concisão, na economia sintática e nos cortes elípticos, e por vezes dialoga com imagens e recursos da poesia japonesa, como acontece nesta peça: "Vagueiam pela casa / o homem, a mosca e o ar -- / ninguém descansa ${ }^{143 ",}$, onde a enumeração de personagens humanos e não-humanos em um mesmo cenário e situação recorda os princípios da interdependência e da compaixão budista por todos os seres vivos, temas de numerosos haicais de Bashô, como este poema, traduzido por Kimi Takenaka e Alberto Marsicano: "em profundo silêncio / o menino, a cotovia / o branco crisântemo $^{144 \text { " }}$ (BASHÔ, 1997: 10). A reflexão filosófica é a tonalidade que predomina na maioria das composições de $A$ boca na fonte, em outro ponto de contato com os aforismos de autores alemães como Nietzsche e Novalis; essa "busca do primordial, do ato de beber diretamente da fonte”, escreve Maria João Cantinho, está contida já no título da obra, que alude à imersão "no sentido da natureza e simultaneamente da linguagem" (idem). A inflexão filosofante, sob o signo da água, aparece já na peça de abertura do volume: "Não separes a água / da sua espuma - / a vida é só uma" (BRITO, 2010: 7), que parece responder aos axiomas de Tales de Mileto (“tudo é água”) e Heráclito de Éfeso ("ninguém se banha duas vezes no mesmo rio"), bem como à tradicional imagem budista que representa o mundo fenomênico como algo temporário, mutável, sem realidade permanente, tal como a espuma nas águas de um rio. Casimiro de Brito, divergindo da ótica budista, parece dizer o oposto: que essência e aparência,

\footnotetext{
${ }^{143}$ BRITO, 2012: 14.
} 
substância e acidente formam uma unidade ("a vida é só uma"). O elemento líquido aparece em diversas composições do livro, em geral com o mesmo viés existencial ou filosofante, por vezes com timbre melancólico: "Silêncio. Ouçam / a vida - água correndo / cada vez mais triste" (idem, 16), que recorda a imagem da clepsidra, na poesia de Camilo Pessanha; "Em cada pedra / um rio que não cessa / de louvar as margens" (idem, 26); "Lágrimas que são / cascata pura. Outras vezes / avalanche mortal" (idem, 28). A água, símbolo da mobilidade, fluidez, mutação e brevidade dos fenômenos, é um dos motivos-condutores de A boca na fonte, ao lado de outros elementos da natureza, como as montanhas, as vacas, os bambus, os gatos e os figos, entre muitos outros. Conforme Maria João Cantinho,

Se os elementos e a força da terra e da natureza perpassam a sua poética, sob as mais variadas formas, desde a ínfima gota de chuva ou grão de areia até ao enigmático silêncio das constelações, também o onírico deflagra, a todo o instante, para nos recordar a brevidade da vida e do instante: "Viagem nocturna -/ regresso à origem do sonho/donde nunca saí. (CANTINHO, 2013)

Morte, sonho, infância, destino e linguagem são outros temas que aparecem nesta coletânea de haicais, que compõem uma espécie de diário íntimo do poeta, um registro de lembranças (reais ou inventadas), terrores, desejos, obsessões. O tema mais recorrente talvez seja o da infância, presente em dez poemas, em que se destaca um subtema doloroso, o da orfandade: “A mãe a perdi / no dia em que nasci -- / amor no exílio" (BRITO, 2012: 14); “A mãe não me deu / à luz. Passou-me duma nuvem / para outra" (idem, 12); "O pai ao colo / do filho que traz no colo. / Os dois um só” (idem, 12). A infância é percebida pelo poeta como duas realidades distintas: a biológica, que ele recorda com saudade ${ }^{145}$ - "O cheiro da casa / que já não há: o sabor / dos figos da infância" (idem, 15) e a atemporal, uma infância infinda, cujo único limite é a morte: “Acompanha-me / sem nenhuma idade / a criança que fui" (idem, 22); "Infância sem

\footnotetext{
${ }^{144}$ BASHÔ, 1997: 10.
} 
fim -- / enquanto a morte, felina / se vai instalando" (idem, 19). Thanatos é a contraparte do elogio ao Menino, e está presente numa das mais belas composições do volume: “Caminho devagar -- / viverei menos se caminhar / mais depressa?” (idem, 21). As peças mais originais do livro, no entanto, são as sete que comparecem nas páginas finais, sob o título $C f$. Lautréamont. Traçar um paralelo entre a poesia japonesa, com todo o seu lastro zen-budista, e a prosa cruel de Isidore Ducasse parece um paradoxo, ou mesmo impossibilidade, mas Casimiro de Brito consegue sair-se bem na dificultosa empresa, fazendo uma releitura intertextual focada na imagética surrealizante, como na peça de abertura da série: "A terra não passa / de um imenso cu celeste / fremindo, cantando". Claro, este já não é um haicai stricto sensu, mas um terceto que estabelece o diálogo possível entre elementos na estética japonesa - concisão, fala popular, imagens raras, relação Céu-Terra, o imprevisto - e o repertório linguístico e temático dos Cantos de Maldoror, como a pederastia (indicada, de maneira metonímica, na palavra $\mathrm{cu}$ ), a imaginação fantástica ou bizarra, a atribuição de características humanas a formas inanimadas (este "cu celeste / fremindo, cantando", que recorda ainda o William Burroughs de $O$ homem que ensinou o seи си a falar).

Em outro poema da série, Casimiro de Brito escreve: "Mãos vegetais / raízes de árvores invisíveis / trepando nas veias". Neste poema, ainda mais estranho que o anterior, as aliterações em $v$ e $s$ podem ser comparadas aos trocadilhos e jogos verbais da poesia japonesa, como o kakekotoba, e as "árvores invisíveis", numa leitura um pouco forçada, podem remeter ao signo da estação do ano, o kigo; porém, a fúria semântica e metafórica dessas linhas está bem mais próxima do simbolismo e do surrealismo europeus, movimentos aos quais Lautréamont, em geral, é associado. "Mãos vegetais" é uma bela imagem, mas talvez soasse, a um poeta como Bashô, mera

\footnotetext{
${ }^{145}$ A saudade dos pais também é um tema caro à poesia japonesa: "O grito do faisão / Que saudade imensa de meu pai e minha mãe" (Bashô) (in: FRANCHETTI, 2012: 80).
} 
exibição de virtuosismo; "árvores invisíveis" é igualmente construção mental, diferente do registro da observação direta dos fenômenos. A organização estrutural do poema em duas partes, separadas por um travessão, aproxima-se da lógica compositiva de muitos haicais japoneses (p. ex., "Cerejas do anoitecer - / Hoje também / já é outrora”, de Issa ${ }^{146}$, na tradução de Paulo Franchetti), mas o efeito causado é totalmente diverso: no haicai, mesmo a sinestesia, a metáfora e o paradoxo remetem a uma paisagem observada, ou à ação de algum elemento da natureza, sem nenhuma brecha para relações intertextuais cultas, obscuridade ou devaneios do poeta. Ao colocar em primeiro plano a sua fantasmagoria pessoal, parodiando as fantasias de Lautréamont, Casimiro de Brito, guiado "pelo rigor e pela claridade enigmática do pensamento" (CANTINHO, 2013), caminha para além da mera adaptação de uma forma poética oriental para o nosso idioma, obtendo um resultado poético denso, com originalidade formal e temática.

${ }^{146}$ In FRANCHETTI, 1990: 99. 


\subsection{Herberto Helder e o princípio da estranheza}

Herberto Helder (1930), companheiro de geração de Casimiro de Brito e participante do movimento da Poesia Experimental Portuguesa $(P O-E X)^{147}$, publicou no Jornal de Letras e Artes de Lisboa, em janeiro de 1963, artigos sobre a poesia japonesa, e posteriormente dedicou-se à tradução de haicais de Bashô e seus discípulos para o português, que reuniria mais tarde na antologia $O$ bebedor nocturno, lançada em 1968, que teve sucessivas edições, sendo a mais recente a de 2010. Comentaremos neste tópico o trabalho tradutório de $\mathrm{HH}$ e a presença de elementos da poesia japonesa em sua obra criativa, como o princípio da analogia e a linguagem paradoxal dos koans (公案).

Conforme Maria Estela Guedes, o fascínio de Helder por diferentes discursos étnicos - dos haicais à poesia esquimó, dos textos orais dos peles-vermelhas aos hieróglifos egípcios, dos cantos mitológicos pré-colombianos ao Cântico dos cânticos do Antigo Testamento - acompanha o escritor desde o início de seu trabalho literário e se manifesta em diversos outros livros, como As magias, Oulof e Poemas ameríndios. “Ao verter para o português textos próprios das culturas e mesmo das liturgias de outros povos", escreve Maria Estela Guedes, "HHelder busca uma ancestralidade literária, uma parentela que não pertence ao foro do DNA, e sim ao da imaginação criadora, ou do sonho, como the chama Alexandrian" (GUEDES, 2010: 53). Fascinado pelo aspecto mágico ou encantatório das línguas antigas, realçado pelos jogos sonoros aliterativos, pelas repetições e permutações de vocábulos, Helder irá pesquisar o artesanato semântico de várias literaturas, para incorporar procedimentos em seu próprio fazer poético. Conforme Maria Estela Guedes, “as sonoridades das línguas estranhas, por vezes apreendidas independentemente de significado, contando mais com o ritmo e a

\footnotetext{
147 Herberto Helder participou do primeiro número dos Cadernos de Poesia Experimental com um fragmento de A máquina de emaranhar paisagens. Posteriormente, afastou-se do grupo.
} 
surpresa provocados pelos sons, aproximam-se da música” (idem, 44) e também dos “jogos infantis" (idem, 45), próximos a certas experiências dadaístas e surrealistas, como as praticadas por Antonin Artaud. "Glossolalias e fenômenos fonéticos com o mesmo impacto estão presentes n'As magias, em títulos de obras, como Eloi Lelia Doura e Oulof, e até em textos jornalísticos", observa a autora (idem, 44). Em Photomathon \& vox (1979), por exemplo, Helder cria insólitas palavras abstratas como LGOGERYCHWYRNDROBWLLLLANTYSILIOGOGOGOCH (idem). Poeta obscuro ${ }^{148}$ como Heráclito, Helder se relaciona “com o misterioso, o mágico, a Esfinge” (idem, 45) e faz da tradução uma forma de máscara dramática ou heteronímia. Ou ainda, como diz Maria Estela Guedes: “O poeta, mediante a tradução, participa diretamente na cultura a que pertence o poema tribal, apropriando-se dela. Essa apropriação tem consequências intelectuais e estéticas" (idem, 52) que são diferentes do enfoque colonialista, que banaliza ou descaracteriza a cultura do Outro, seja ele africano, oriental ou ameríndio, para dominá-lo. O diálogo estabelecido por Herberto Helder com as culturas nãoocidentais vai em sentido diverso: "No momento em que o poeta assimila o elemento exótico, hibridando-o com o endótico, contraria a tendência colonialista e simultaneamente cria algo de novo, no plano artístico" (idem, 52-53).

Os textos japoneses traduzidos por Herberto Helder em $O$ bebedor noturno estão divididos em três seções: Poemas zen, conjunto de 16 dísticos sem informação sobre autoria ou procedência; Canções de camponeses do Japão, quatro peças breves traduzidas na forma do quarteto; e Quinze haikus japoneses, seleção de poemas de Bashô, Kikaku, Kyorai, Shikô, Buson, Issa e Ransetsu. Conforme observa Maria Estela Guedes, "uma vez que raramente identifica as suas fontes, vamos partir do princípio que

\footnotetext{
148 “Vamos relembrar: algures, n'Os passos em volta, o poeta suspira: Meu Deus, faz com que eu seja sempre um poeta obscuro." (GUEDES, 2010: 46)
} 


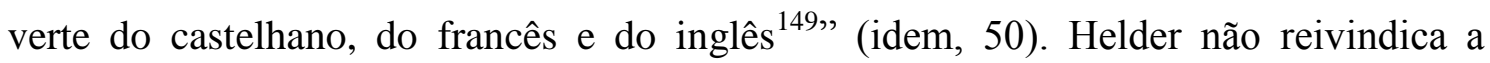
tradução como transposição rigorosa do sentido de uma língua para a outra, não adiciona notas explicativas, referências bibliográficas ou ensaios críticos para expor o seu método tradutório; o seu diálogo com a poesia japonesa não é o trabalho de um erudito, mas de um poeta que acredita na capacidade imaginativa, na intertextualidade e na mestiçagem para evocar rutilâncias dos textos originais. Em seus "poemas mudados para o português" (subtítulo de $O$ bebedor nocturno), Helder realiza "uma apropriação da cultura transportada no texto étnico, e seguidamente uma recriação de tais elementos na língua-mãe. Quer isso dizer que o resultado é sempre um texto mestiço" (idem). A prática tradutória de Helder afasta-se da historicidade e da busca de uma pureza original, da tentação ilusória de restabelecer uma suposta verdade de um determinado passado, sugerindo mesmo "a impossibilidade de resgatar o passado acumulado", conforme diz Izabela Leal no ensaio Da memória à tradução: o erro das musas distraídas (in JACOTO, 2011: 32). Segundo a autora, "no caso da tradução, há de fato uma limitação, que é a impossibilidade de recuperar o que está dito no texto original. A tradução nos faz ver o caráter fragmentário da linguagem, já que as línguas se diferenciam entre si ao mesmo tempo em que são aparentadas" (idem). A tradução literária, de acordo com a autora, revela não apenas "a distância entre aquilo que é visado e o que se atinge de fato" mas também o fato de que "não há incompletude apenas na relação entre texto original e texto traduzido", porque "o próprio original já é portador de um princípio de estranheza, pois apresenta uma dessemelhança em relação a si próprio" (idem). A partir destas considerações, Izabela Leal define a arte tradutória de Herberto Helder como "prática deformadora e violadora da língua materna" e como "desvio", uma vez que recusa ser "reprodução do original" para se firmar como

\footnotetext{
${ }^{149}$ Segundo Jorge Souza Braga, a maioria dos poemas traduzidos por Herberto Helder em $O$ bebedor nocturno baseia-se na antologia Trésors de la poésie universelle, de Roger Caillois.
} 
"vitalidade e esplendor" (idem). O ponto de partida da recriação helderiana é o "erro", mas um erro criativo, que se converte em "erro feliz", que "transforma o lugar do erro por meio de uma 'invenção de movimento', de passos em volta, e então 'acerta (...) com a potência natural da poesia"” (idem, 33). O signo do erro, da errância, do deslocamento rege toda a poética helderiana, e em particular a sua poética da tradução, mas nem por isso devemos deduzir que o poeta, em suas criativas versões dos haicais japoneses para o português, cai no puro espontaneísmo, na variação aleatória ou em intuições divorciadas do espírito da cultura com que dialoga. Podemos observar o extremo cuidado com que Helder recria em português a concisão, visualidade e imaginário da poética japonesa nestes dois poemas, também "reimaginados" por Casimiro de Brito em seu livro Poemas orientais:

Libélula vermelha.

Tira-lhe as asas:

um pimentão.

Kikaku (1661-1707)

Pimentão vermelho.

Põe-lhe umas asas:

Libélula

Bashô (1644-1694) $)^{150}$

\section{Tradução: Herberto Helder}

A réplica de Bashô ao poema de seu discípulo Kikaku não é apenas um exercício imaginativo ou estético, mas uma afirmação da piedade budista, que se manifesta por todos os seres vivos, inclusive a libélula ${ }^{151}$. Em vez de mutilar o inseto para transformá-

\footnotetext{
${ }^{150}$ HELDER, 2010: 136.

${ }^{151}$ Wenceslau de Moraes escreve o seguinte comentário: "Bashô era extremamente bondoso para com todos os animais, não admitindo que os maltratassem, mesmo por pensamento. Em certa ocasião, jornadeava ele campos fora, em companhia de Kikaku, seu discípulo. Este, dando fé de um tira-olhos escarlate, exclamou em verso:
}

Aka tombo 
lo em algo semelhante ao pimentão, Bashô faz a operação inversa, para transformar o pimentão em símile da libélula. Casimiro de Brito assim traduziu estes poemas:

Uma libélula vermelha.

Tirai-lhe as asas:

Oh! Um pimento!...

(Kikaku)

Um pimento vermelho.

Daí-lhe umas asas:

Oh! Uma libélula!...

(Bashô) ${ }^{152}$

Tradução: Casimiro de Brito

As versões criativas de Herberto Helder obtêm força e consistência no idioma português pela extrema economia sintática, elemento essencial da arte poética japonesa, e pela espacialização das linhas, que dão mobilidade aos poemas e mimetizam a visualidade da escrita caligráfica. Casimiro de Brito, por sua vez, introduz interjeições e reticências que enfatizam de maneira exagerada o sentido da surpresa, já contido na própria referencialidade, e utiliza um vocábulo de uso pouco corrente (pimento) em vez da forma mais popular (pimentão). Coloquialidade, jogos verbais, compaixão budista e imaginário do universo infantil são recorrentes na poesia de Kobayashi Issa, também traduzido por Helder em seu pequeno caderno japonês:

\footnotetext{
Hane wo tottara

To-garashi

que quer dizer: -- Arranquem as asas a um tira-olhos escarlate; ficará um pimento. - Esperava o discípulo, talvez, do mestre um cumprimento. Mas Bashô repreendeu-o vivamente, por tão cruel brincadeira; e, corrigindo os versos, proferiu:

To-garashi

Hane wo tsuketara

Aka tombo

que quer dizer: -- Juntem asas a um pimento; ficará um tira-olhos escarlate.” (MORAES, 1926: 198-199)

${ }^{152}$ BRITO, 1962: 20.
} 
Caracol,

lento, lento, lento - sobe

o Fuji ${ }^{153}$.

Um cuco

cuja voz se arrasta

sobre as águas ${ }^{154}$.

Tradução: Herberto Helder

O primeiro poema acentua ainda mais a visualidade como elemento essencial para a construção do sentido, com a palavra "caracol" isolada na primeira linha, sugerindo solidão, e a tripla ocorrência da palavra "lento" na linha seguinte, a mais longa do poema, indicando na própria fisionomia semântica a vagarosa caminhada até o monte Fuji. O segundo poema, de construção sintática e visual mais simples, materializa a força metafórica pela extrema concisão, em medidas métricas ainda mais condensadas Helder usou versos de 2-5-3 sílabas, em vez de 5-7-5, frequentes no haicai tradicional. A escolha dos poemas japoneses "mudados para o português" em $O$ bebedor nocturno favoreceu as composições de caráter fanopaico, talvez por afinidade eletiva do tradutor, ele próprio um cultor da imagem rara, insólita, herdeiro da tradição de Lautréamont e Reverdy. Assim, encontramos haicais com imagens de alto impacto, como estes:

Crescente lunar.

O tubarão esconde a cabeça debaixo das vagas.

(Shikô)

A lua deitou sobre as coisas uma toalha de prata.

Azáleas brancas ${ }^{155}$.

(Shikô)

153 Podemos comparar a tradução de Helder com as realizadas por R. H. Blyth ("O snail, / Climb Mt. Fuji, / Slowly, slowly!”), Octavio Paz (“Al Fuji subes / despacio - pero subes, / caracolito”), Corinne Atlan e Zéno Bianu (“Grimpe en douceur / petit escargot - / tu es sur le Fuji!”).

${ }^{154}$ HELDER, 2010: 138.

${ }^{155}$ Idem, 137. 
Casa sob as flores brancas.

Onde bater?

Mancha sombria da porta ${ }^{156}$

(Kyorai)

Ao mudar poemas japoneses para o português, Helder veste a máscara dramática de um autor clássico do século XVII, desenvolvendo temas e técnicas presentes em sua própria poesia - imagens desmesuradas, metáforas imprevistas - e recursos quase ausentes em sua lírica, como a escrita concisa, substantiva, com alta resolução e precisão de contornos. Ao contrário de Casimiro de Brito, não escreveu haicais, mas encontramos em sua escrita criativa a presença do koan, tipo de fábula ou pergunta enigmática que perturba a lógica rotineira pela construção inesperada e inusitada do discurso. Conforme o físico austríaco Fritjof Capra, "os koans são enigmas absurdos, cuidadosamente preparados com o fito de fazer com que o estudante do Zen se aperceba, do modo mais dramático, das limitações da lógica e do raciocínio" (CAPRA, 1989: 44). O caráter irracional, paradoxal desses enigmas, prossegue o autor, "torna impossível a sua decifração através do pensamento. Os koans são elaborados precisamente para parar o processo do pensamento e, dessa forma, preparar o estudante para a experiência não-verbal da realidade" (idem). "O koan pode ser descrito como um problema apresentado pelo mestre a seu discípulo", diz o pesquisador brasileiro Georges da Silva. "Consiste numa frase, às vezes ilógica e risível; é um exercício especial, cuja finalidade é ativar a mente, pela qual o discípulo chega à compreensão intuitiva da verdade" (SILVA, Georges, e HOMENKO, Rita: 1993, 236). Em seu livro Bashô, a lágrima do peixe, Paulo Leminski escreve a respeito: "há centenas de koans, reunidos em grandes coleções, com os ditos e feitos dos mestres mais famosos" (LEMINSKI, 1983: 73). Nos mosteiros zen-budistas, esse tipo de enigma verbal era transmitido pelo

\footnotetext{
${ }^{156}$ Idem.
} 
mestre a seu discípulo, para que este "concentre-se, durante um tempo que pode ser longo, trabalhando mentalmente sobre ele, absorvendo sua 'outra lógica"' (idem). Como ilustração dessa singular variante da parábola, que recorda os ensinamentos dos filósofos cínicos gregos, Leminski cita o seguinte koan:

Po-chang tinha tantos alunos que se viu obrigado a abrir outro mosteiro. Para achar alguém apto a ser mestre na nova casa, juntou seus monges e colocou um cântaro na frente deles, dizendo:

— Sem o chamarem de cântaro, me digam o que é isso.

— Você não pode chamá-lo um pedaço de lenha, disse o monge principal.

Nesta altura, o cozinheiro do mosteiro derrubou o cântaro com um pontapé e afastouse.

Po-chang deu a direção do novo mosteiro ao cozinheiro. (LEMINSKI, 1983: 72).

O koan era transmitido de mestre a discípulo na escola zen-budista Rinzai, introduzida nas ilhas japonesas por Eisai (1141-1251), que encontrou grande aceitação por parte da aristocracia guerreira. Outro exemplo clássico de koan é referido por Ricardo M. Gonçalves em seu livro Textos budistas e zen-budistas: "Você pode ouvir o ruído de suas duas mãos batendo uma na outra; ouça agora o ruído de uma só mão" (in GONÇALVES, 1999: 24). Ao receber um koan como este, o discípulo, no início, busca "uma solução lógica e racional" (idem, 25), mas "as tentativas nesse sentido são sumariamente rechaçadas pelo instrutor. Afinal, cansado de esgrimir inutilmente com suas armas habituais, a mente do praticante abre-se para o despertar do conhecimento intuitivo" (idem). O espírito do koan está presente numa notável composição de Helder publicada inicialmente nos Cadernos de Poesia Experimental e incluída posteriormente em seu único livro de prosa ficcional, Os passos em volta (1963):

\section{TEORIA DAS CORES}

Era uma vez um pintor que tinha um aquário e, dentro do aquário, um peixe encarnado. Vivia o peixe tranqüilamente acompanhado pela sua cor encarnada, quando a certa altura começou a tornar-se negro a partir - digamos - de dentro. Era um nó negro por detrás da cor vermelha e que, insidioso, se desenvolvia para fora, 
alastrando-se e tomando conta de todo o peixe. Por fora do aquário, o pintor assistia surpreendido à chegada do novo peixe.

O problema do artista era este: obrigado a interromper o quadro que pintava e onde estava a aparecer o vermelho do seu peixe, não sabia agora o que fazer da cor preta que o peixe lhe ensinava. Assim, os elementos do problema constituíam-se na própria observação dos fatos e punham-se por uma ordem, a saber:

1) peixe, cor vermelha, pintor, em que a cor vermelha era o nexo estabelecido entre o peixe e o quadro, através do pintor;

2) peixe, cor preta, pintor, em que a cor preta formava a insídia do real e abria um abismo na primitiva fidelidade do pintor.

Ao meditar acerca das razões por que o peixe mudara de cor precisamente na hora em que o pintor assentava na sua fidelidade, ele pensou que, lá dentro do aquário, o peixe, realizando o seu número de prestidigitação, pretendia fazer notar que existia apenas uma lei que abrange tanto o mundo das coisas como o da imaginação. Essa lei seria a metamorfose. Compreendida a nova espécie de fidelidade, o artista pintou na sua tela um peixe amarelo.

(HELDER, 2004: 21)

A fábula helderiana desarticula o raciocínio linear, de matriz cartesiana, e compõe uma outra lógica, intuitiva, que nasce da percepção da impermanência, ou contínuo vir-a-ser dos fenômenos, que HH nomeia como "lei da metamorfose". Este é um princípio caro ao pensamento budista, que considera a realidade material desprovida de identidade estável, uma vez que está sujeita às incessantes mutações e condicionamentos espaçotemporais. A impermanência, desse modo, é o mesmo que a vacuidade, ou ausência de um "eu" separado do mundo: na filosofia budista, tudo e todos estão relacionados num sistema de interdependência, cuja face visível é o universo material (samsara) e a face invisível, o vazio (sunyata). O peixe vermelho que se torna negro e por fim é representado como amarelo é uma metáfora pictórica dessa "lei da metamorfose" que permeia todo o texto, construído numa forma híbrida entre a fábula e o poema em prosa. No texto Comunicação acadêmica, de 1963, HH radicaliza a "lei da metamorfose", aplicando a técnica de tema e variações, própria da música ouvida em concerto (recordemos que a variação é uma forma musical em que a melodia é repetida ao longo da composição com mudanças em seu ritmo, compasso, tonalidade, modo, 
harmonização, arabesco etc., "com a única e imperiosa condição de permitir que o ouvinte sempre possa reconhecer mais ou menos distintamente o tema original”"157):

Gato dormindo debaixo de um pimenteiro: gato amarelo folhas verdíssimas pimentos vermelhos: sono redondo: sombras pequenas de pimentos: no sono do gato: folhas sombrias dentro do amarelo: pimentos dormindo num gato vermelho: verdes redondos no sono do pimenteiro: o amarelo: da cabeça do gato nascem pimentos verdíssimos de sono verdíssimo debaixo de um pimenteiro amarelo: a sombra do gato dando folhas redondas sonhando amarelo sobre dormindo os pimentos: água: secura sombria do gato vermelho: o sonho da água dorme no pimenteiro: a sombra da cal das paredes secas dorme no gato de água amarela: a cal dá pimentos que sonham nas folhas do gato: o sono da cal dá sombras redondas no gato enrolado no vermelho: a água é uma sombra o gato é uma folha o sono é um pimenteiro: a cal é o verdíssimo do sono seco dando sombra no amarelo: pimenteiro redondo: pimentos de cal enrolados no sonho do silêncio amarelo: o silêncio dá gatos que sonham pimentos que dão sono na cal que dá sombra nas folhas que dão água na secura do tempo vermelho: o tempo enrola-se debaixo da cabeça do pimenteiro que se enrola no gato de cal do sono amarelo: o sono de dentro dos pimentos debaixo do redondo verdísssimo enrolado no sonho: e dorme o pimenteiro com as sombras do gato redondo enrolandose nas folhas: silêncio de sonho sono de tempo: tudo amarelo: noite do pimenteiro sono da cal folha do gato sonho das sombras do verdíssimo vermelho: secura da noite: noite do gato na noite da cal com a noite das folhas dentro da noite do verdíssimo debaixo da noite do sonho diante da noite do pimenteiro após a noite da água conforme a noite debaixo com a noite enrolada contra a noite do amarelo desde a noite das sombras consoante a noite redonda para a noite de dentro durante a noite do vermelho detrás da noite dos tempos debaixo da noite sem à frente do com da noite conforme a noite conforme: a noite dos tempos: um gato de dentro desaparecendo num pimenteiro: pimenteiro desaparecendo: a cal morrendo no sonho das folhas pequenas: o silêncio de tudo no mundo inteiro:

et caeteramente vosso inteiro:

herberto helder:

em janeiro:

mil novecentos e sessenta e três

(HELDER, 2004: 181)

A insólita composição helderiana, construída a partir da combinação e permutação de poucos elementos semânticos - recurso empregado também na poesia oral de diferentes etnias africanas e indígenas ${ }^{158}$, na poesia visual do barroco português e nas experiências

${ }^{157}$ HOLLANDA, 1986: 1754.

158 No livro As magias, que reúne poemas de diferentes tradições e culturas de caráter iniciático, encontramos peças como esta, recolhida da literatura oral dos pigmeus: "O animal corre, e passa, e morre. 
de autores contemporâneos como Ana Hatherly - ao mesmo tempo que esvazia o sentido habitual das palavras, convertidas em termos quase abstratos, constroi novos significados, realçando a força sugestiva de termos como "amarelo", "gato", "água", "verdíssimo", "pimenteiro". As próprias conjunções, preposições e sinais de pontuação (no caso, os dois pontos) funcionam como elementos rítmicos, em construções que já não obedecem à sintaxe regular, mas sim à fluência melódica de cada frase. $\mathrm{O}$ caráter híbrido desse texto, desenvolvido num jorro contínuo, é ainda mais acentuado que o da Teoria das Cores, com a disposição espacial das últimas linhas sugerindo analogias com a poesia espacial de Mallarmé, em contraste com a prosa blocada das linhas anteriores. A poeticidade do texto é reforçada, sobretudo, pelas estranhas combinações imagéticas - "sono redondo", "silêncio amarelo", "verdíssimo vermelho" - e pelas ações inusitadas derivadas dessa alquimia semântica: "a cal dá pimentos que sonham nas folhas do gato", "dorme o pimenteiro com as sombras do gato redondo", "um gato de dentro desaparecendo num pimenteiro" etc., que recordam poemas infantis ou os jogos praticados pelos surrealistas franceses. À maneira do koan, o texto de HH não apresenta qualquer conclusão redutora, mas explicita a ambiguidade, a mutabilidade e impermanência da linguagem e do mundo.

E é o grande frio. / É o grande frio da noite, é a escuridão. / O pássaro voa, e passa, e morre. E é o grande frio. / É o grande frio da noite, é a escuridão. / O peixe nada, e passa, e morre. E é o grande frio. / O homem come, e dorme, e morre. E é o grande frio" (HELDER, 1987: 26). Em outro poema oral, este dos iugures, lemos: "Ao negro mar ressoante possas tu chegar. / Possas chegar e três vezes abrir a porta negra. / Ao ressoante mar amarelo possas tu chegar. / Pela tempestade amarela que sopra possas tu chegar. / Possas chegar montado num cavalo amarelo. / Empunhando um dardo amarelo possas tu chegar. / Possas chegar ao ressoante mar vermelho. / Pela tempestade vermelha que sopra possas tu chegar. / Possas chegar com as mãos cheias de preciosas pedras vermelhas. / Vestido de bárbaros couros vermelhos possas tu chegar" (idem, 25 


\subsection{Ana Hatherly e a reinvenção da escrita}

Ana Hatherly (1929), autora que integrou o movimento da Poesia Experimental (PO-EX) na década de 1960, dialogou com a estética japonesa em diversos momentos de seu percurso criativo, que inclui, além da escrita poética, ensaística, tradutória ${ }^{159} \mathrm{e}$ ficcional, incursões na música erudita, artes visuais, televisão e cinema. Neste tópico, comentaremos a presença de elementos da poética japonesa em sua produção textual, como a caligrafia, a relação íntima entre poesia e pintura e o uso da parábola, do paradoxo e outros recursos tradicionais dos koans japoneses. No texto de apresentação que elaborou para o livro 463 Tisanas (Lisboa: 2006), a escritora portuguesa rememora os vetores intelectuais que interessaram aos poetas de sua geração, como a linguística pós-saussureana, o estruturalismo, "os avanços da ciência em todas as áreas do saber e as novas fronteiras da imaginação" (HATHERLY, 2006: 12), e ainda "outra tendência internacional que nos anos 60 vigorou no Ocidente e pela qual me interessei" que foi "o contato com o Budismo Zen, que na cultura europeia de então floresceu de uma maneira avassaladora" (idem). O conhecimento do Outro oriental, o Outro japonês, que após a II Guerra Mundial torna-se um ícone estético, filosófico e espiritual, "dominou o pensamento e a criatividade dos jovens progressistas desse tempo" (idem), especialmente os que eram proclives à experimentação formal e à busca de novas referências em culturas não-ocidentais (recordemos o interesse de Allen Ginsberg, Gary

\footnotetext{
${ }^{159} \mathrm{Na}$ antologia Uma rã que salta, organizada por Casimiro de Brito, encontramos nada menos que dezessete haicais de Bashô traduzidos por Ana Hatherly, a partir de versões inglesas e francesas. Em sua recriação do poema da rã, a autora portuguesa obtém estas linhas: "Velho tanque sonolento / rã que salta / som de água" (BRITO, 1995: 61), preservando a concisão e o sentido da maioria das numerosas traduções do poema, mas incluindo um adjetivo ausente no texto original (sonolento). Em outra peça, a poeta portuguesa constroi um vigoroso ritmo icônico para representar o movimento das ondas, desprezando os sinais de pontuação: "O mar escurecendo / os gansos gritando circulando / brancos" (idem, 62). Na maioria de suas traduções, porém, a autora privilegia a recuperação do sentido literal, com poucas subversões semânticas. No campo da literatura chinesa, registramos que Ana Hatherly publicou em 2003 o volume $O$ vagabundo do dharma - 25 poemas de Han Shan, com caligrafias de Li Kwok Wing. Para a elaboração do trabalho, a escritora portuguesa contou com a colaboração de Jacques Pimpaneau, que realizou as versões literais do chinês para o português.
} 
Snyder $^{160}$, Michael McClure e Jerome Rothenberg pela arte e tradições espirituais de etnias indígenas norte-americanas, e também de tribos africanas, australianas, esquimós, entre outras, o que resultou em valiosos estudos e traduções da chamada etnopoesia). No caso específico da escritora portuguesa, o contato com a escrita, formas artísticas e sistemas de ideias do repertório cultural japonês inseminou boa parte de sua produção poética e pictórica, e em particular a série das tisanas. Em depoimento sobre a gênese dessa série notável de poemas em prosa, cujos primeiros resultados foram publicados na revista Operação n. 2 - Estruturas poéticas, em 1967, escreve a autora: "Eu, que nos anos 50 e 60 estudara a escrita chinesa, que tanto iria marcar minha produção artística (...), mergulhei também no Budismo Zen, sobretudo no ensinamento veiculado pelos desconcertantes textos usados pelos Mestres japoneses para instruir os seus discípulos" (idem, 12-13). Estes singulares textos - os koans - prossegue a escritora portuguesa, “causaram-me uma profunda impressão e, em termos estruturais, deixaram a sua marca na minha concepção das Tisanas" (idem, 13). No prólogo ao livro 222 Tisanas, publicado em 1988, a autora diz:

Se grande parte das primeiras Tisanas, quanto ao conteúdo são fábulas ou anti-fábulas ou mitos subvertidos, o seu estilo de escrita é um estilo de vanguarda, com acentuados desvios da norma (na lógica, na pontuação etc., podendo ver-se aí a influência do Experimentalismo)... No que diz respeito à estrutura da narrativa aí pode detectar-se algo herdado da tradição Zen: todas as Tisanas obedecem a um princípio semelhante ao do koan budista, são sempre ações, direta ou indiretamente, um acontecimento, um evento, mesmo que seja apenas linguístico. Todas as Tisanas dizem sempre respeito a algo que acontece, ao significado ou à questionação do significado de um acontecer que se depara ao narrador e que se oferece ao leitor como um desafio. Em todas as Tisanas encontra-se algo desta "indeterminação deslizante" do pensamento Zen, associada a uma técnica de destruição da certeza, mas também consequência de uma meditação sobre a natureza da linguagem baseada em pressupostos da linguística moderna... As Tisanas também são uma reflexão sobre a ilusão da verdade que é a arte, uma reflexão sobre a cultura como projeção da invenção do real, uma reflexão sobre o jogo como veículo de conhecimento na sua função libertadora de energia, criadora de liberdade e de reflexão sobre as formas ${ }^{161}$. (idem, 13-14)

\footnotetext{
${ }^{160}$ Gary Snyder é também um estudioso das culturas chinesa e japonesa e adepto do Budismo Zen, tendo realizado traduções do poeta chinês Han Shan (também traduzido por Ana Hatherly), episódio narrado por Jack Kerouac no romance Dharma Bums ("Vagabundos iluminados" na edição brasileira).

${ }^{161}$ A citação foi extraída do depoimento da autora no texto de apresentação ao volume 463 Tisanas, de 2006.
} 
A estrutura narrativa do koan, em que o humor e o non sense são utilizados para perturbar a lógica convencional e com isso abalar nossa visão rotineira da realidade, permitindo a compreensão intuitiva dos fenômenos, é o ponto de partida para a invenção das tisanas, onde o elemento lúdico está em primeiro plano. A fábula zenbudista não revela um sentido ontológico, ético ou metafísico, mas desenvolve um campo de "indeterminação deslizante, associada a uma técnica de destruição da certeza" (idem), que aponta para o artificialismo do discurso e do pensamento - e, portanto, de nosso princípio de "realidade". O koan procura mostrar o caráter impermanente dos fenômenos, não para negar a sua ocorrência, mas para sinalizar a sua natureza efêmera, assim como é a dos sonhos. Podemos fazer uma comparação ilustrativa entre as tisanas e alguns koans relatados por Taisen Deshimaru, no livro A tigela e o bastão:

\section{A CABEÇA E O RABO}

Havia uma serpente cuja cabeça e cujo rabo viviam brigando. $\mathrm{O}$ rabo dizia:

-- Fico sempre para trás, enquanto tu vais na frente, e sou obrigado a seguir-te.

No fim de contas, o rabo enrolou-se numa árvore. Não queria mais avançar. A cabeça viu uma bonita rã. Quis comê-la, mas não pode.

Diante disso, a cabeça permitiu ao rabo que fosse na frente. Mas, como o rabo não tinha olhos, caiu num buraco e a cabeça morreu na queda.

(DESHIMARU, 1983: 33)

\section{TISANA 12}

Era uma vez duas serpentes que não gostavam uma da outra. Um dia, encontraram-se num caminho muito estreito e como não gostavam uma da outra devoraram-se mutuamente. Quando cada uma devorou a outra não ficou nada. Esta história tradicional demonstra que se deve amar o próximo ou então ter muito cuidado com o que se comer $($ sic $)$.

(HATHERLY, 2006a: 23) 


\section{O PÁSSARO DE DUAS CABEÇAS}

Trata-se de um pássaro de duas cabeças (e um corpo), cuja cabeça direita é comilona e hábil em encontrar comida, ao passo que a esquerda, igualmente comilona, é desajeitada. A cabeça direita podia sempre alimentar-se à vontade, e a esquerda ficava sempre com fome.

Por isso, um dia, a cabeça esquerda disse à cabeça direita:

-- Conheço, pertinho daqui, uma erva deliciosa com a qual te regalarás; vem, vou conduzir-te ao lugar.

A cabecinha esquerda sabia que, na verdade, se tratava de veneno, mas desejava promover, desse modo, a morte da cabeça direita para, depois, poder comer a seu talante. O que na verdade aconteceu foi que, primeiro, o corpo se intoxicou e, a seguir, as duas cabeças morreram.

(DESHIMARU, 1983: 32)

\section{TISANA 13}

Era uma vez duas orelhas que viviam no alto da cabeça de um gato. Cansadas de passarem a vida arrebitadas frequentemente lamentavam a sua triste sorte. Até que um dia resolveram que não queriam mais viver arrebitadas e começaram estudando a maneira de acabar com essa aviltante postura. Diz a esquerda para a direita e se nos encolhêssemos. Diz a direita boa ideia começa tu para eu ver como é. a esquerda encolheu-se. Dobrou-se sobre si mesma com a maior firmeza. Esteve assim um certo tempo até que o gato irritado começou a coçar a orelha enrolada e como ela resistisse o gato só parou quando ela se reergueu escorrendo sangue.

(HATHERLY, 2006a: 23)

As afinidades estilísticas entre as tisanas e os koans são evidentes - humor, ironia, paradoxo, enredo similar ao da fábula, com a incorporação de animais como personagens com características humanas, ações inesperadas e, sobretudo, discurso enigmático. No livro A experiência do prodígio - bases teóricas e antologia de textosvisuais portugueses dos séculos XVII e XVIII, Ana Hatherly afirma que "o gosto pela decifração" se baseia "num conceito de que o significado do mundo é oculto (...) e nos obriga ao constante esforço da escolha através da interpretação" (HATHERLY, 1983: 222). A conquista da sabedoria por meio de enigmas e paradoxos é exatamente a meta do koan, mas, diferente do poema visual barroco, que podia ser interpretado por quem tivesse ciência de certo repertório de símbolos, o koan é uma máquina de produzir 
perplexidades, pois nesse caso o enigma não tem respostas prévias, mas oferece, no próprio ato da enunciação, uma pluralidade de experiências imaginativas, verbais e nãoverbais, até a obtenção de um estado intuitivo, não-racional, que resolve sem resolver a proposição misteriosa ("Voltemos ao Koan. O que é o sentido? Uma mala fechada que nunca teve fecho. Eis a ironia da humildade ${ }^{162 \%, ~ d i z ~ a ~ T i s a n a ~ 275) . ~ O ~ k o a n, ~ a s s i m ~ c o m o ~}$ a "obra aberta" de Umberto Eco, é um mecanismo sutil que sugere uma pluralidade de rotas de leitura e de construção de significados, não um mistério decifrável a partir de uma única via interpretativa. Neste sentido, podemos invocar a imagem do labirinto multicursivo, cuja peculiar arquitetura oferece ao peregrino diferentes trajetos que conduzem até o centro (tema estudado por Ana Hatherly no livro A casa das musas).

Em Mapas da imaginação e da memória, coleção de 97 desenhos de arte em branco e preto realizados pela autora portuguesa na mesma década em que surgiram as primeiras tisanas, a estratégia de atingir uma "indeterminação deslizante, associada a uma técnica de destruição de certeza" (HATHERLY, 2006: 13-14) é radicalizada: não se trata mais de alterar, ampliar ou esvaziar o sentido das palavras, mas de converter a própria escrita, reinventada, em abstração gráfica. Os desenhos de Mapas da imaginação e da memória não são metáforas visuais, onde acontece a substituição de um signo por outro, criando novas relações de significados, nem são construções metonímicas, onde a parte designa o todo, dentro do mesmo campo de referências, logo, sem descontinuidade entre conceito e realidade. Podemos considerar esses trabalhos como ruídos gráficos, sinais sem sentido vocabular, que se aproximam da gestualidade pela forte expressividade dos contornos ${ }^{163}$. A dimensão puramente plástica dessa escrita

\footnotetext{
${ }^{162}$ HATHERLY: 2006, 110.

${ }^{163}$ Shutaro Mukai, professor da Musashino Art University, considera que "os kanji são associados com o sentido do tato ou a sensação física" (in CAMPOS: 2000, 18) e que evocam, para o japonês, "a memória dos movimentos musculares envolvidos no ato de escrever" (idem, 19); na escrita ideogrâmica, segundo Mukai, "os gestos originais ainda permanecem em sua forma original ou num eco dessa forma" (idem).
} 
imaginária, que utiliza com frequência a mancha e o borrão para tornar ainda mais irreconhecível a identificação das formas (Figura 1), recorda, efetivamente, a arte da caligrafia japonesa, ou shodô (Figura 2), "linguagem que vira imagem, imagem que é linguagem” (VÁRIOS AUTORES: 2008, 7), na concisa definição de Teixeira Coelho, curador da exposição Mestres do sho contemporâneo: caligrafia artística japonesa, que aconteceu em 2008 no Museu de Arte de São Paulo (MASP).

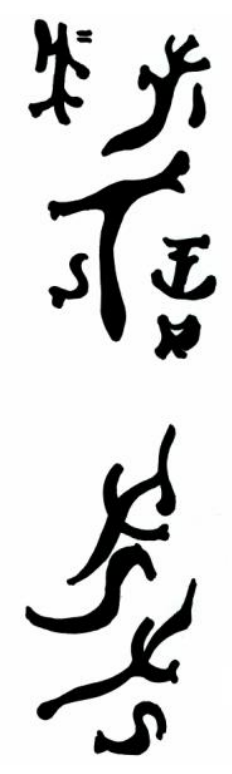

Figura 7

A comparação, ainda que restrita ao campo da visualidade, não é arbitrária, uma vez que Ana Hatherly, em suas tisanas, se define como um "poeta-pintor", ou ainda como "criadora de imagens" e "artista visual" (HATHERLY, 2005: 106). Em outra passagem, a autora situa o seu projeto artístico em uma "longa tradição de poetas-pintorescalígrafos, criadores de imagens mais ou menos diretamente ligados à escrita como pintura de signos" (idem, 113). Ao invocar a tradição dos poetas-calígrafos chineses e japoneses (entre os quais se destaca o haicaísta Buson, 1716-1783), Ana Hatherly aponta para as afinidades entre escrita, poesia e pintura, compreendidas como "materialização do imaginário" (idem, 107) em um sistema de signos que pressupõe a 
leitura ${ }^{164}$. "Seja qual for o tipo de escrita, visual, sonora, gestual, seja qual for o tipo de suporte, estamos sempre ante imagens codificadas" (idem). Toda codificação, por sua vez, requer um trabalho de decodificação "para que a comunicação se estabeleça, mesmo que essa comunicação deseje comunicar a sua incomunicabilidade" (idem). Ao criar uma escrita imaginária em que os signos não possuem significado prévio, ela propõe não apenas a reinvenção da escrita, mas também da leitura, que solicita a participação sensível e inteligente do leitor, qui met les choses en scène, elle-même ${ }^{165}$.

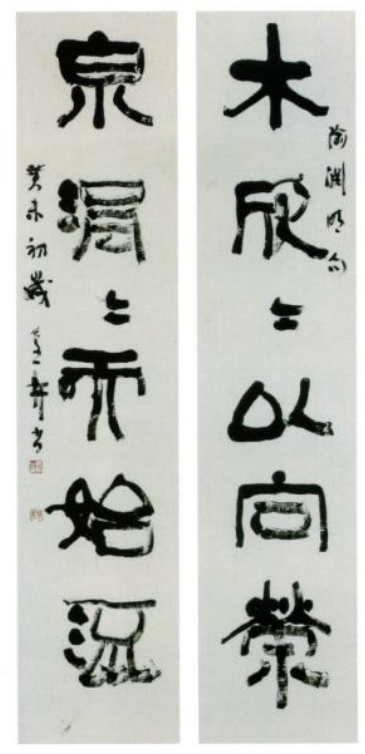

\section{Figura 8}

No texto de apresentação ao volume Mapas da imaginação e da memória, (1973), que reúne parte dos desenhos dessa estranha cartografia, Ana Hatherly rememora a gênese desse trabalho criativo, que desafia as fronteiras entre literatura e artes visuais:

Embora ao longo da minha vida tivesse sempre praticado regularmente o que usa chamar-se desenho de arte, foi sobretudo na década de 60 que me apliquei a realizar

\footnotetext{
${ }^{164} \mathrm{O}$ estudioso italiano Girolamo Mancuso afirma: "Uma vez que não existe na China uma nítida diferenciação entre pintura, caligrafia e poesia, o poeta é muitas vezes calígrafo e pintor. Na raiz da impessoalidade e da atemporalidade da poesia chinesa, encontramos, portanto, o influxo do sistema de escrita, mas num sentido bem diverso de como o entendiam Fenollosa e Pound; o que conta não é a sua natureza ideo-gráfica, mas o seu cunho gráfico; isto se patenteia de modo evidente através das formas 'cursivas', que se afastam ao máximo da reprodução iconográfica, e nas quais é exaltada a qualidade puramente gráfica do signo" (in CAMPOS: 2000, 65).
}

${ }^{165}$ MALLARMÉ, 1984: 10. 
um trabalho sistemático e orientado para um fim específico, dentro da área do desenho.

Nos primeiros anos dessa década eu realizava já algumas obras gestualistas quando um dia, quase por acidente, adquiri um dicionário de inglês-chinês, que incluía uma larga secção dedicada ao chinês arcaico. É certo que nessa época eu conhecia já algumas escritas arcaicas e estava relativamente bem informada acerca da importância que, ao longo do milênio, a palavra como imagem (ou o signo em geral) teve na história da evolução das formas, culminando na actualidade das experiências letristas e da poesia concreta que, aliás, também pratiquei; mas na verdade, o meu trabalho de pesquisa sistemática da escrita começou propriamente quando iniciei o estudo metódico desse dicionário.

Ao iniciar esse estudo estava fascinada e obcecada.

À medida que ia aprofundando o meu conhecimento gestual dessa escrita eu via, na destreza crescente com que desenhava esses caracteres, na fluência do meu conhecimento deles, eu via aquilo que posso descrever como 'a minha mão torna-se inteligente', quer dizer, experimentalmente observava, ao mesmo tempo que realizava, o acto de conhecer essa escrita; porque o estudo dessa caligrafia foi um meio que eu escolhi para realizar uma investigação que poderia ter seguido outro caminho ou utilizado outro veículo, igualmente adequado, uma vez que o meu empenho nesse acto era, acima de tudo, o de investigar, tanto quanto a minha subjetividade o permitisse, $o$ conhecimento do acto criador e da sua gratuidade.

Talvez um ano depois de ter iniciado esse estudo, verifiquei que começava a desligarme da representação direta desses caracteres e a realizar outros, que lembravam ainda os chineses arcaicos mas que gradualmente se iam despojando do antropomorfismo característico acentuando-se neles a tendência geométrica.

\section{(...)}

Revi então outras escritas do oriente, médio-oriente, norte da áfrica, escandinávia, culminando na escrita latina

\section{(...)}

Como um primeiro resultado desse trabalho de pesquisa, publiquei em 1967, na revista de poesia experimental OPERAÇÃO 1, um "Alfabeto Estrutural". Tratava-se duma proposta para uma nova escrita que, hoje, vejo, apresentei sem os devidos esclarecimentos. Hoje considero também que a designação "Alfabeto Estrutural" poderia ser substituída com vantagem pela de "Escrita Conceptual", por exemplo, embora essa questão possa ser secundária.

(HATHERLY, 1973: 7-8)

O "alfabeto estrutural" criado por Ana Hatherly a partir do estudo de antigas formas

de escrita com acentuado aspecto visual, como a chinesa, a escandinava, a latina, a 
semítica, entre outras, é composto de oito ${ }^{166}$ caracteres (Figura 3) que se combinam em múltiplas formas, como se fossem sílabas ou fonemas; porém, a autora não atribuiu nenhum valor semântico ou mesmo vocálico a essas imagens, que possuem apenas sentido plástico ${ }^{167}$. Conforme escreve a poeta portuguesa, "não há entre esses elementos nenhuma diferença hierárquica; a sua ordenação não pode ser comparada, por exemplo, à dos elementos numa escala diatônica ou numa série, ou a uma sucessão de algarismos implicando uma ordem de valor" (idem, 10). Os desenhos caligráficos de Ana Hatherly não constituem uma língua, mas "uma forma de linguagem”, cujos elementos "poderão ter valor metafórico na medida do seu valor sinalético, semiológico, icônico” (idem).

A propriedade evidente do "alfabeto estrutural" (ou "conceitual") de Ana Hatherly é a sua capacidade de combinação e permutação de caracteres, assim como acontece no anagrama, recurso empregado com frequência na poesia visual do barroco português, com evidente caráter de jogo. O caráter arbitrário do anagrama, "rico de possibilidades", segundo Ana Hatherly, "se poderia tornar, por uma generalização possível, paradigmático do ato criador" (idem, 11). Ao contrário do que acontece no uso cotidiano da língua, no "ato poético criador" o artista procurará "as combinações nãoúteis, isto é, procurará para além da necessidade. Quero dizer: joga. Provoca o acaso, suscita o fortuito, colhe o inesperado mesmo dentro do conhecido, não rejeita o inexplicável, o ambíguo, o incompreensível” (idem).

\footnotetext{
${ }^{166}$ Os oito caracteres do alfabeto plástico criado por Ana Hatherly recordam os $P a$ Kua (ou Ba Gua) da filosofia clássica chinesa, que são oito trigramas dispostos em círculo, representando a terra, o céu, a água, o vento, o fogo, o lago, o trovão e a montanha. Estes oito desenhos combinam-se entre si formando os 64 hexagramas do I king (ou I ching), o Livro das mutações.

${ }^{167}$ Conforme E. M. de Melo e Castro, “a questão da legibilidade é também totalmente secundária (...). É que ler, nesse caso, parece não ser decifrar... Também, sob um ponto de vista semiótico, não devemos procurar nestes poemas caligráficos, nem índices nem ícones. Apenas uma relação convencional aleatória se estabelece entre os textos e a sua caligrafia, o que lhes dá uma natureza simbólica, embora esvaziada de qualquer sentido, além da sua própria representação, visto que não se descortina a lei dessa relação convencional. (...) As caligrafias são objetos escritos, dos quais emana a sua própria substância. (in HATHERLY, 1992: 102-103)"
} 


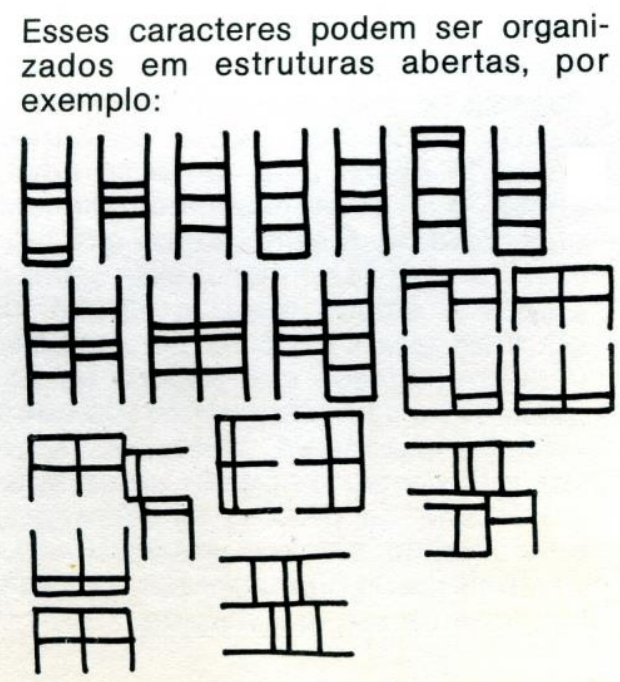

\section{Figura 9}

Manuel Castro Caldas considera que nas combinações e permutações dessa singular pictografia ocorrem "modos particulares de acumulação, sobreposição, encadeamento e interação de linha e mancha" que sugerem "a lógica gráfica de pequenos acidentes e pausas inerentes à escrita" (in HATHERLY, 1992: 107), e ainda "certos efeitos pictóricos de textura ou contraste" que "podem lembrar rasuras, encavalitar de linhas, miniaturização" (idem), assim como acontece na caligrafia dos ideogramas chineses, onde a mancha, o borrão e a deformação dos signos atribuem à escrita uma textura próxima à da gestualidade. (As considerações de Manuel Castro Caldas podem ser estendidas também à série de trabalhos visuais Hand made / Obra recente, de Ana Hatherly, publicada em 2000 pela Fundação Calouste Gulbenkian, que reúne uma série de desenhos caligráficos e pinturas da autora portuguesa que exploram o caráter visual e tátil das composições plásticas, com evidente ressonância da caligrafia artística japonesa e do expressionismo abstrato, especialmente na série Pintura sobre cartão.) O crítico aponta também a "recuperação do sagrado", a "função mágica" e o "primitivismo" nos desenhos de Ana Hatherly (caso similar ao de Picasso, fascinado pela estatuaria africana), ainda que se trate de uma arte profana, radicada na experiência 
lúdica entre leitor e caligrafia. Ao se apropriar de formas de outras culturas e transformá-las em seus desenhos, a artista portuguesa realiza uma "pilhagem" que é "o reverso de todo colonialismo" (idem, 108), pois não se trata de uma alienação, redução ou submissão do diferente, mas de sua reimaginação inventiva. Retirando de seus contextos históricos e culturais os sinais gráficos de diferentes tipos de escritura e atribuindo-lhes outras possibilidades de sentido, Ana Hatherly constroi uma mitologia singular, recupera uma "origem" ao mesmo tempo ancestral, mítica e personalíssima. A realização pictórica de Ana Hatherly é compreendida por Melo e Castro como uma “construção utópica” (idem, 98), por esvaziar os sinais de seu caráter utilitário, tornando-os livres. As letras do alfabeto plástico da poeta portuguesa não servem "para comunicar senão a sua própria existência, como potenciais meios de estabelecer contatos organizados entre a mente dos homens e as coisas que eles próprios fabricam" (idem). O sentido inutilitário dos desenhos de arte de Ana Hatherly é evidente em seu próprio trabalho artesanal, que utiliza instrumentos e materiais como a tinta da china, caneta de feltro e mesmo esferográfica, em suportes como o cartão, o bilhete postal e a folha de caderno. Os desenhos, em sua maior parte, não excedem o tamanho de um pequeno cartão, e utilizam uma sucinta variedade cromática - preto, azul, sépia, castanho, vermelho. Uma parte dos desenhos da série Mapas da imaginação e da memória foi coletada em um elegante volume vertical, de $10 \mathrm{~cm} \times 15 \mathrm{~cm}$, com tiragem de apenas quinhentos exemplares, numerados e assinados pela autora. Reunidos em volume, os Mapas da imaginação e da memória assumem o perfil de um "livro de poemas caligráficos", como notou Melo e Castro (idem, 100), em nova subversão de conceitos e estruturas comunicativas pela autora portuguesa: a inscrição mítica, ancestral da poesia, da magia e das artes pictóricas, torna-se por fim sentença mallarmeana: tudo o que existe é para acabar em um livro. 


\subsection{A erotografia poética de Melo e Castro}

Ernesto Manuel Geraldes de Melo e Castro (1932), que assina sua obra poética, ficcional, teórica e ensaística como E. M. de Melo e Castro, foi um dos expoentes do movimento da Poesia Experimental $(P O-E X)$ na década de 1960, ao lado de Ana Hatherly, Salette Tavares, Antônio Aragão e Herberto Helder. Comentaremos, neste tópico, a ressonância da estética do ideograma em sua produção textual, a presença da síntese, da concisão, da visualidade e da justaposição de signos em sua poesia visual, além do diálogo criativo com o haicai, remodelado pelo autor numa estrutura de quatro versos e temática erótica, em dissonância com a quase ausência do elemento amoroso no haicai japonês tradicional. Em seu livro Ideogramas, publicado em 1962, Melo e Castro reúne 29 poemas concretos, publicados sem qualquer introdução ou nota explicativa; este é o marco zero da Poesia Concreta e do Experimentalismo em Portugal $^{168}$ (embora seja possível rastrearmos uma pré-história da visualidade na poesia portuguesa na época maneirista e barroca, tema estudado por Ana Hatherly em $A$ experiência do prodígio: bases teóricas e antologia de textos-visuais portugueses dos

\footnotetext{
168 O poeta concretista brasileiro Pedro Xisto (ele próprio estudioso da cultura japonesa e autor de numerosos haicais) escreveu uma carta a Melo e Castro em 04/11/1962 onde comenta o livro do autor português: "Acabo de receber, gratamente, seus IDEOGRAMAS. E, desde o princípio, já se deflagra uma questão ou reação em cadeia: são eles de ler? Não e sim. Pois não são de ler e ver? E ainda não e sim, que há mais. E é ter. Mas ter é sim ou não? Quem, afinal, tem a poesia? E que é o que a poesia tem? Tem um não ou um $\underline{\text { sim? }}$ ? Quem sabe, na poesia, isto é, no poema, há de se ler, $\underline{\text { ver, }} \underline{\text { ter, }}$ verter um $\underline{\text { ser }}$ - o próprio

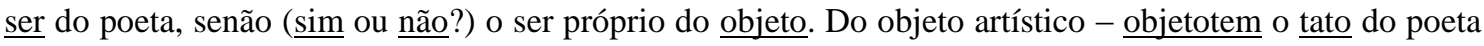
que, atento, sente ao tato - um ato, o ato criador. Estranho totem, desalienado, não exclusivo do poeta (que é do rei?) e da sua grei e da sua lei mas, sim, compreensivo de outras gentes e outras terras, lado a lado, as mesmas. Alto teto, donde o pêndulo se precipita em círculos de tontura e aceleração de ritmos no fundo do poço ou, exatamente, à fonte alfabética. É como se, sobre o choque de sismos o poeta viesse da serra ao vale. Rolam os dados (hipnotismo?). O certo é que funciona o gerador - a máquinaimagem. E, do círculo aberto em cristal e arco-íris, o gesto poético traga novos perfis. Se a asa sem ar resiste e à casa sem sol é triste - edifício de ferro e cimento - água vem, água vai, e se faz troca ou dura pura. A casa, em si, fala, e há (ah!) luta e flor. E, porque, também há espinha dorsal, um livro monumento ergue-se por fim". (A carta de Pedro Xisto a E. M. de Melo e Castro foi publicada na revista eletrônica brasileira Zunái, na página http://zunai.com.br/post/56772592455/carta-de-pedro-xisto-para-e-m-de-melo-e-castro) A respeito dessa carta, e da relação com Pedro Xisto, escreve o poeta português, no mesmo link: "Só mais tarde, em 1966, quando vim pela primeira vez ao Brasil e a São Paulo é que conheci pessoalmente o Pedro Xisto e com ele falei sobre o Haikai. Quando regressei a Lisboa levei comigo alguns poemas inéditos do Pedro Xisto que foram publicados no no 2 da Revista de Poesia Experimental (1966) e no $\mathrm{n}^{\circ} 1$ da revista Operação (1967), de minha iniciativa. Hoje esta carta é um documento verdadeiramente notável e único, nas relações poéticas entre Portugal e Brasil, nesses anos de 60!"
} 
séculos XVII e XVIII, e também em composições esparsas de Mário de Sá-Carneiro, Mário Cesariny, Jaime Salazar Sampaio ou Alexandre O’Neill).

A estratégia adotada por Melo e Castro nesta coleção de poemas estabelece uma clara consonância entre disposição gráfico-espacial e referente: assim, no poema Pêndulo, letras e sílabas são distribuídas na página de modo a sugerir o movimento pendular (Figura 10); em Edifício, as letras que formam o poema são inseridas em linhas verticais e horizontais, simulando contornos de um prédio; em Ritmo, a variação gráfica do texto indica a alternância de tempos fortes e fracos do compasso musical, além de reforçar, visualmente, as relações de ambiguidade entre as palavras ritmo e riso.

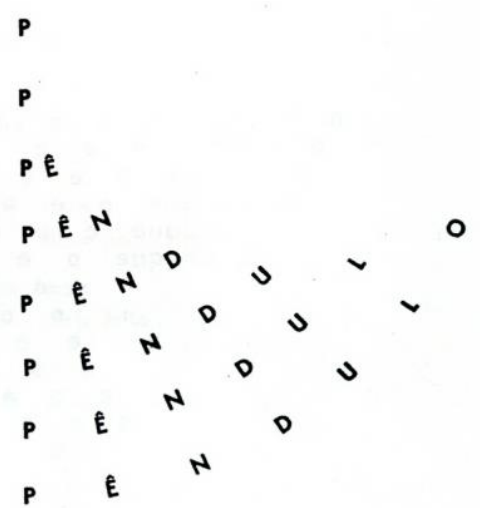

\section{Figura 10}

A representação visual do "conteúdo" do poema, nos Ideogramas de Melo e Castro, recorda as experiências de Guillaume Apollinaire ${ }^{169}$ nos Caligrammes (1918), como por exemplo na peça il pleut (Figura 11), em que os versos, dispostos em linhas verticais e inclinadas, simulam a própria chuva - experiência que pode ter inspirado a composição pluvial / fluvial, de Augusto de Campos (Figura 12), com uma diferença metodológica 
clara: enquanto Apollinaire ${ }^{170}$ preserva o verso e o discurso sintático linear dentro da nova arquitetura semântica, Augusto de Campos rompe com a versificação e o pensamento gramatical, construindo seu poema com apenas duas palavras.

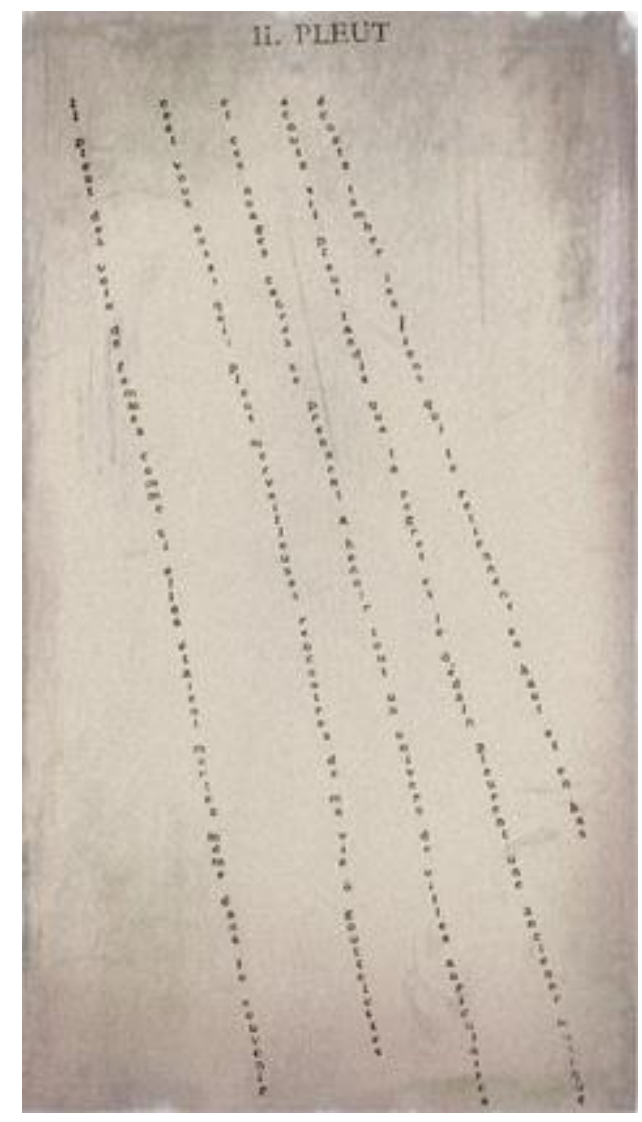

\section{Figura 11}

A relação mimética fundo/forma, no entanto, é apenas o aspecto mais superficial na apropriação do princípio do ideograma pelos poetas concretistas, que valorizaram, sobretudo, a técnica de justaposição ou montagem da poesia ideográfica chinesa e japonesa. "Nesse processo de composição" - dizem Fenollosa e Pound - "duas coisas conjugadas não produzem uma terceira, mas sugerem alguma relação fundamental entre

\footnotetext{
169 Apollinaire é o autor de uma frase adotada como grito de guerra pelos concretistas: "il faut que notre intelligence s'habitue à comprendre synthético-ideographiquement au lieu de analytico-discursivement" (in CAMPOS, Augusto; PIGNATARI, Décio; CAMPOS, Haroldo. 1975, 156).

${ }^{170}$ A esse respeito, escreve Haroldo de Campos: 'É bem verdade que o 'caligrama' de Apollinaire se perde na pictografia, exterior, imposta (no poema com forma de objetos, na figuração artificial à composição); mas sua formulação teórica (...) é fecunda e profética" (CAMPOS, Augusto; PIGNATARI, Décio; CAMPOS, Haroldo. 1975, 97).
} 
ambas" (CAMPOS, Augusto; PIGNATARI, Décio; CAMPOS, Haroldo: 1975, 96). "Em

The cantos, de E. P., o ideograma é o princípio de estrutura presidindo a interação de blocos de ideias, que se criticam, reiteram e iluminam mutuamente" (idem), escreve Haroldo de Campos no texto Aspectos da Poesia Concreta. Prossegue o poeta e ensaísta brasileiro: "O isolamento de núcleos temáticos em cadeias de essências e medulas impõe a tomada de consciência do espaço gráfico como fator de organização do corpo do poema (vejam-se, nesse sentido, especialmente, os Cantos pisanos e a seção Perfuratriz de rochas, última publicada, de 1955)" (idem).

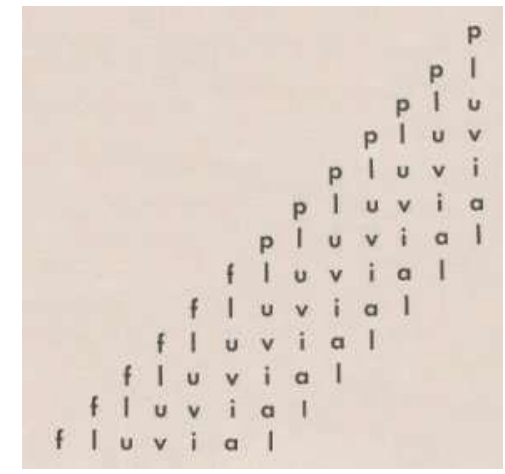

\section{Figura 12}

A poesia de Melo e Castro, apesar das evidentes aproximações que podem ser feitas com o ideograma - quanto à concisão, visualidade, ruptura com a sintaxe e com o discurso linear, substituído pela aglutinação de partículas semânticas em estruturas gráfico-espaciais $^{171}$-, faz pouco uso da justaposição analógica de signos que caracteriza o ideograma; na maioria das composições de seu livro, como é o caso de Pêndulo e Arco-ìris, predomina o figurativismo icônico de Apollinaire, ou ainda experiências cinéticas que dialogam com a poesia visual do barroco português como é o caso de

\footnotetext{
${ }^{171}$ Conforme escreveu o poeta português, "quase toda a Poesia Experimental Portuguesa produzida a partir da década de 60 se pode inscrever dentro de uma denominação geral de POESIA ESPACIAL, uma vez que as suas coordenadas visuais são dominantes" (MELO E CASTRO e HATHERLY: 1981, 9). A expressão se justifica porque "é no campo das experiências visuais e espaciais do texto, considerado como matéria substantiva de que o poema se produz, que a pesquisa morfológica, fonética, sintática e semiológica se projetou e se projeta" (idem).
} 
Tontura (Figura 13), composto de uma única palavra, que é fragmentada em diferentes sequências de letras, dispostas em círculos concêntricos. O poema solicita uma nova dinâmica de leitura para reproduzir, pelo movimento lúdico, o efeito desejado pela composição. Neste poema, assim como em outras peças de Ideogramas, é claro o uso de técnicas de combinação, permutação, anagrama e leitura labiríntica ${ }^{172}$ que permitem a multiplicidade de rotas de interpretação e construção do sentido, tema estudado por Umberto Eco em seu clássico livro Obra aberta, de 1962 (precedido por artigo de Haroldo de Campos, publicado em 1955 no jornal Diário de São Paulo).

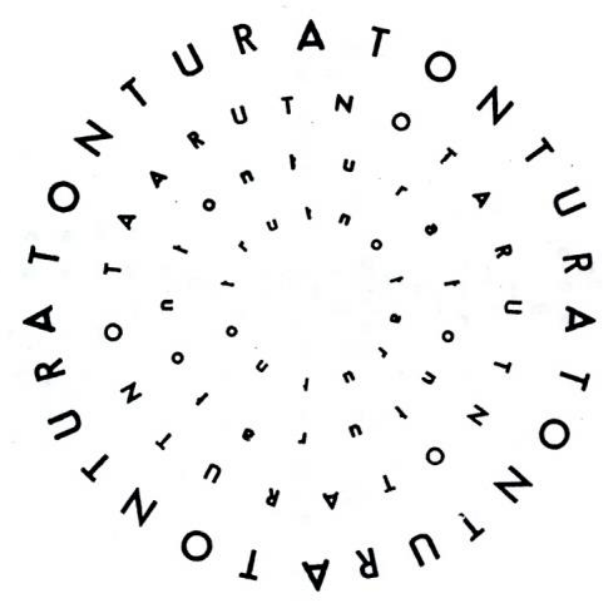

\section{Figura 13}

Uma composição curiosa do volume, que se aproxima do princípio da montagem analógica do ideograma, é o poema (sem título) que associa os termos antitéticos sim e não aos verbos ler, ver, ter e ser, alinhados em colunas verticais e dispostos em diferentes sequências (Figura 14). A formatação visual da peça, próxima ao abstracionismo, obedece a uma lógica estrutural e rítmica que dispensa a relação mimética entre fundo e forma. O leitor é convidado a percorrer o poema por diversas

\footnotetext{
172 A influência das técnicas de composição da poesia visual do barroco português na vanguarda experimental portuguesa foi abordada por nós no livro A estética do labirinto: barroco e modernidade em Ana Hatherly (Bauru: Lumme Editor, 2010).
} 
trilhas labirínticas, construindo múltiplas possibilidades de leitura: podemos pensar, nesse caso, no "ideograma como processo relacional, enquanto metáfora estrutural ${ }^{173}$ ".

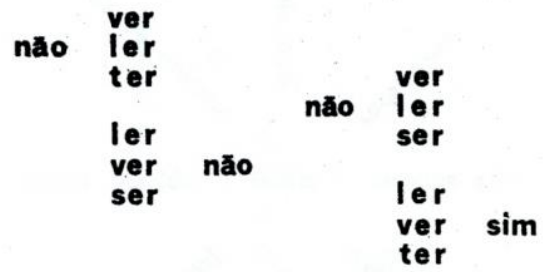

\section{Figura 14}

No ensaio Ideograma, anagrama, diagrama, Haroldo de Campos afirma que, no pensamento chinês, “os opostos não são excluídos, mas integrados numa inter-relação dinâmica, mutuamente complementar" (idem, 84). Isto significa que, em lugar da "lógica da identidade" típica da lógica ocidental, prevalece, no sistema de ideias chinês, uma "lógica da correlação", onde o interesse está "no inter-relacionar dos signos (caracteres), não na substância" (idem, 84-85). Ao silogismo de origem grega, baseado na "lógica da identidade", o pensamento chinês prefere a analogia. O poema de Melo e Castro, que entre o "sim" e o "não" perfila quatro verbos no infinitivo, sem sujeito (mesmo oculto), oferece ao leitor todas as possibilidades de analogia e, portanto, de construção de significados. O poeta português, diga-se de passagem, desconhecia, em meados da década de 1960, a poesia chinesa ou japonesa, e tomou conhecimento do princípio do ideograma por meio dos poetas concretistas brasileiros ${ }^{174}$, que por sua vez absorveram as reflexões de Fenollosa, Ezra Pound e Eisenstein sobre a escrita

\footnotetext{
${ }^{173}$ CAMPOS: 2000, 66.

${ }^{174}$ Dois acontecimentos referidos por Melo e Castro antecedem o surgimento da Poesia Experimental: "primeiro, a rápida visita a Lisboa de Décio Pignatari, em 1956 (...), após o seu já histórico encontro com Gomringer; segundo, a publicação em 1962, pela Embaixada do Brasil em Lisboa, de uma pequena mas excelente compilação da Poesia Concreta do Grupo Noigandres" (MELO E CASTRO e HATHERLY: 1981, 9)
} 
ideográfica. De modo distinto das experiências realizadas por Ana Hatherly no mesmo período, com os Mapas da imaginação e da memória, que dialogam com a materialidade da escrita chinesa e o seu caráter caligráfico, Melo e Castro praticou uma abordagem mais conceitual do ideograma, com o filtro dos recursos da poesia visual barroca e da bagagem da poesia de vanguarda das primeiras décadas do século XX.

A obra visual de Melo e Castro ultrapassa o mimetismo icônico e aproxima-se de uma nova geometria da composição em obras posteriores, como a segunda coleção de Ideogramas (1966), os Cinéticos (também de 1966) e sobretudo os Infopoemas (1998), estes últimos realizados com programas de computador. O poema sem título que abre o caderno dos novos Ideogramas é formado por sete palavras entrecruzadas (coração / respiração / inspiração / expiração / espaço / braço / abraço), com as letras em diferentes corpos e fontes, dispostas num conjunto sem contornos discerníveis: o figurativismo cede vez à abstração e a leitura torna-se o terreno da combinação, da permutação e da ambiguidade (Figura 15):

[de ideogramas - 1966 ]

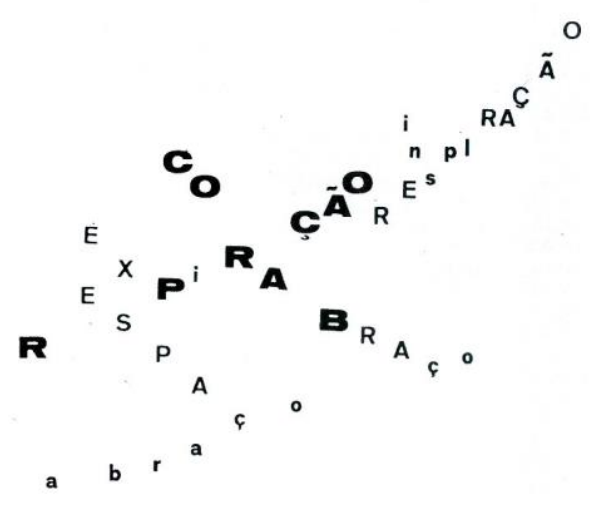

\section{Figura 15}


Em outra peça do ciclo, as palavras man, woman, name e amor são desmembradas e as letras, repetidas e recombinadas em diferentes sequências anagramáticas, formando imagens e sons puramente abstratos (Figura 16) — experiência radicalizada em outra peça, composta pela repetição de apenas duas letras, $s$ e $z$, combinadas e mescladas até a deformação e a mancha (Figura 17):

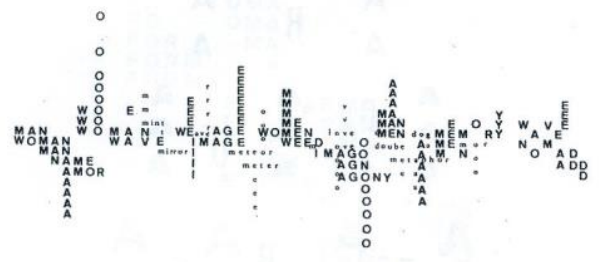

\section{Figura 16}

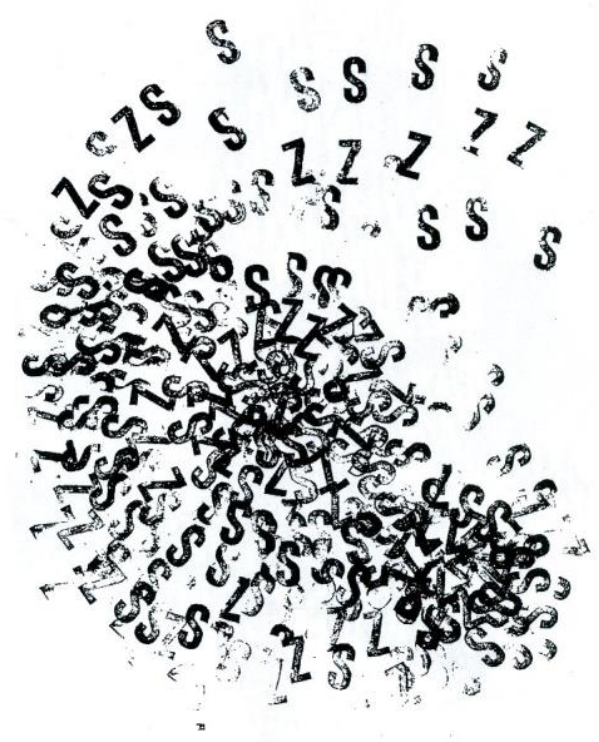

\section{Figura 17}

A série de poemas intitulada Cinéticos, como o próprio nome indica, é um conjunto de poemas visuais que simulam o movimento: diferentes versões de cada imagem gráfica (composta por desenhos geométricos e eventualmente também palavras, sílabas ou letras) são dispostas em sequências que recordam a linguagem cinematográfica. A peça dedicada ao silêncio, formada por cinco retângulos, duas cores (branco / preto) e uma 
única palavra (silêncio) é a que mais se aproxima do princípio do ideograma, tal como entendido por Fenollosa: o sentido da composição é construído pela relação entre as imagens, numa representação visual do som que se transforma em silêncio (Figura 18):
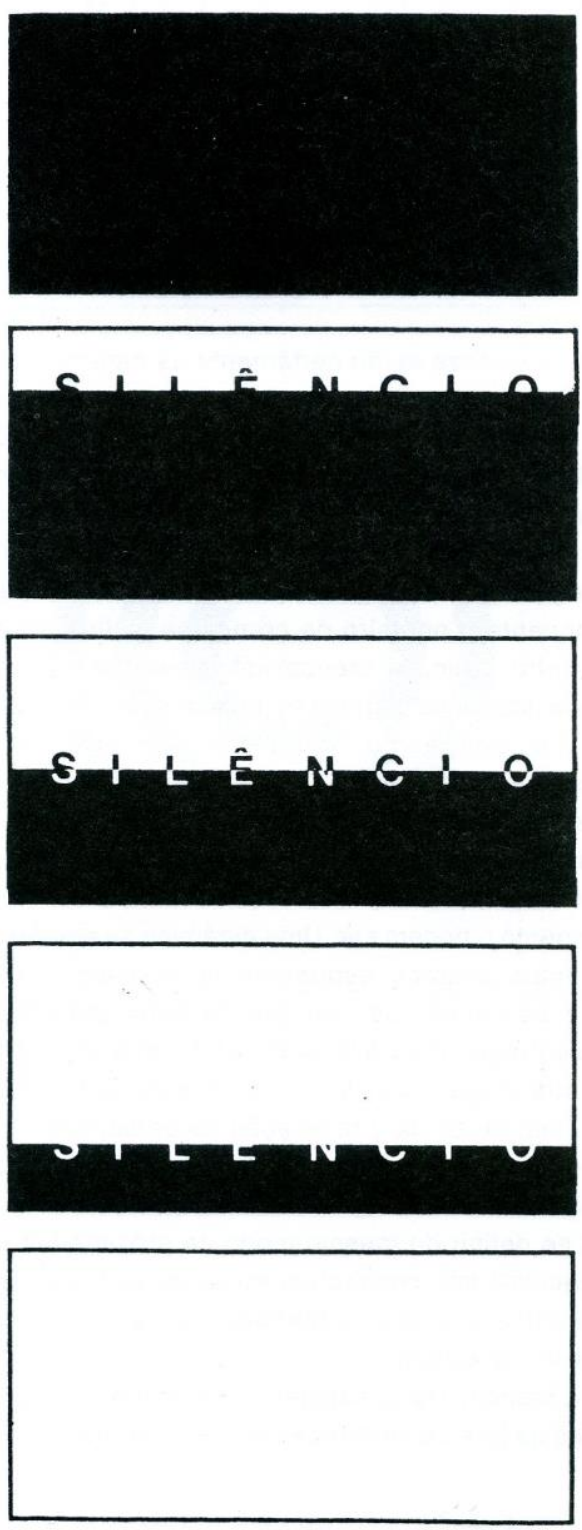

\section{Figura 18}

Nos Infopoemas, cabe destacar as peças da sequência intitulada Transfilm, em que as letras são deformadas e convertidas em pontos, linhas, manchas e figuras puramente abstratas, desprovidas de qualquer valor semântico e possibilidade de leitura (Figura 18). Nessas composições, que dissolvem os limites entre literatura, pintura, tecnologia e 
grafismo, Melo e Castro obtém expressivos resultados plásticos, equiparáveis aos ruídos gráficos de seus ilustres antepassados, os mestres calígrafos japoneses:

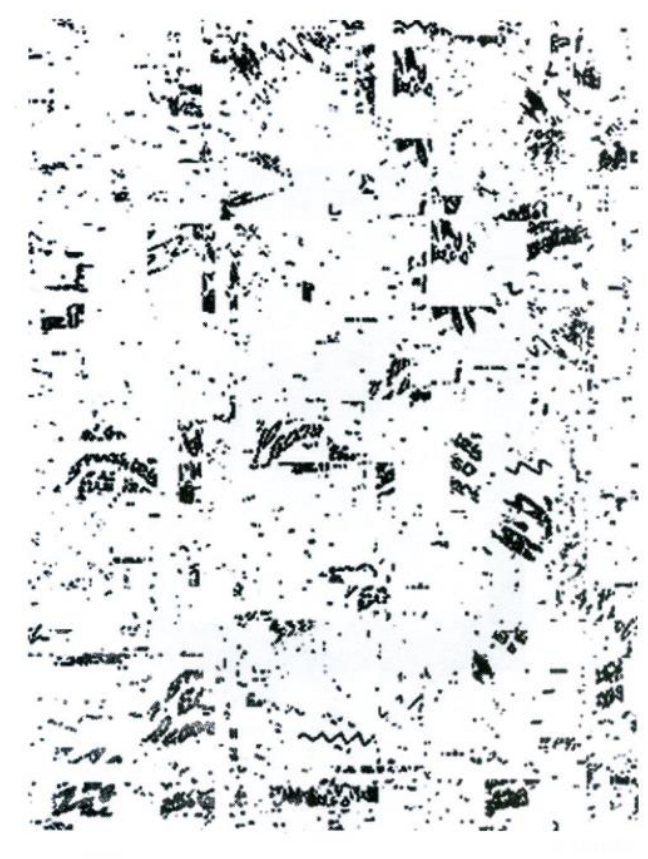

transfim -4

\section{Figura 19}

Diálogo explícito com a poesia japonesa será realizado na série Haiku erótico, conjunto de 14 poemas que integram o volume De entre o rigor e o excesso: um osso, publicado em 1994. Ao contrário do terceto adotado na maioria das tentativas ocidentais de adaptação desse gênero poético, Melo e Castro adota o quarteto (lembremos que o haicai japonês tradicional podia ser escrito em uma, duas, três ou quatro linhas, sendo o quarteto a forma adotada por Wenceslau de Moraes em suas pioneiras transposições do haicai para a língua portuguesa), sem medidas métricas fixas, embora as linhas, em geral, estejam próximas às redondilhas portuguesas ${ }^{175}$. Todas as peças da série são escritas em caixa baixa, sem pontuação, com raras rimas internas ("na onda anda",

\footnotetext{
${ }^{175}$ Consideramos aqui a redondilha menor, de cinco sílabas, e a redondilha maior, de sete sílabas, contadas até a última sílaba tônica, conforme a codificação de Castilho. Na versificação japonesa, assim como ocorria nas cantigas galego-portuguesas, a contagem de sílabas desconsiderava a acentuação final, fato observado e comentado por Álvaro Faleiros em seu livro Tradução e significância nos caligramas de Apollinaire: o espaço gráfico, o metro e a textura fônica (São Paulo: EDUSP, 2003).
} 
"negro loiro", "beijo eixo"), num estilo próximo ao de outras composições experimentais do poeta (como os poemas mais concisos do volume De corpos radiantes, de 1982). O autor português desconsidera as convenções clássicas do gênero, como o a presença do signo da estação do ano (o kigo), a referência ao local onde foi escrito o poema e, sobretudo, a ação, o movimento súbito que faz a ligação entre o céu (eternidade), o homem e a terra (mundo dos fenômenos). Melo e Castro não pretende niponizar a sua lírica, numa fácil aclimatação de flores de lótus, cerejeiras, templos silenciosos, samurais e outros elementos repetidos com certa frequência por poetas ocidentais que tentam reproduzir aquilo que imaginam ser o Japão, o haicai e o zenbudismo. O poeta português escolheu trabalhar a forma japonesa sem renunciar ao seu repertório cultural, à sua formação europeia; não quer convencer o leitor de que a sua sensibilidade está próxima à de Bashô e seus discípulos, nem fingir uma simplicidade que contrarie seu voluntário rebuscamento. Renunciando ao clichê, Melo e Castro realiza uma microlírica de extrema originalidade, a começar pela temática erótica, ausente no haicai japonês tradicional. Sua linguagem é fragmentária, elíptica, e as linhas se sucedem de maneira rápida, como em um videoclipe: "mamilos ilhas / do mar elástico / flores / na pele do peito" (idem, 177). A transformação do corpo humano em um mapa onde estão espalhados ilhas, mares e flores é um recurso metafórico próximo a um preciosismo barroco ${ }^{176}$; em outra composição, de aparente simplicidade, a figura empregada é a metonímia: "fundo e claro / o obscuro fluxo / canto do olho aberto" (idem). A (quase) ausência de rimas é compensada, na maioria das peças, por jogos sonoros de caráter aliterativo ("a saliva sabe", "vulva / volume vago", "nulo de nada") ou ainda por assonâncias (“do sol o toque", "voo no ritmo", “das asas duplas"). Em todos os micropoemas da série, a pedra-de-toque é a representação do ato erótico a

\footnotetext{
${ }^{176}$ Composição similar a esta, no procedimento, é o haicai "na pele do deserto / areia movediça / cetim / de dedos cactus"(idem).
} 
partir de associações com elementos da natureza, que materializam o amor em sua dimensão animal; como inesperado clímax (anticlímax?), o último terceto anula as regras do jogo, numa figuração deliberadamente abstrata do êxtase: "total orgasmo / nulo de nada / luz / sobre a iluminação", linhas que recuperam palavras do vocabulário zen-budista, mas reconfiguradas em outro campo de referências: na erotografia poética de Melo e Castro é pelo corpo que a alma vem. 


\subsection{A "secura verde" de Albano Martins}

Albano Martins (1930) praticou a poesia breve desde os seus primeiros títulos publicados, como Secura verde (1950) e Outros poemas (1951-1952), sob o influxo da poesia grega (o autor licenciou-se em Filologia Clássica pela Universidade de Lisboa e traduziu poemas de Safo e Alceu, epigramas ${ }^{177}$ e dísticos latinos), da quadra portuguesa e outras formas tradicionais, inclusive o terceto, como nesta composição incluída em Coração de bússola (1967): “A vida - essa invenção magnífica / da morte” (MARTINS, 2000: 44), revelando uma tendência "para a condensação, para a ascese vocabular rumo a um dizer essencial”, nas palavras do ensaísta português José Fernando Castro Branco, em seu livro Poética do sensível em Albano Martins (BRANCO, 2004: 51). No presente tópico, estudaremos as analogias entre o processo criativo de Albano Martins e os recursos tradicionais da poesia japonesa, como a brevidade, a rica imagética, o paradoxo e a relação entre texto e imagem, que pode ser observada na disposição geométrica de palavras e linhas na obra textual do autor.

A busca da essência, ou antes dos "cernes e medulas" na expressão poética (para citarmos a conhecida frase de Ezra Pound), que no caso de Albano Martins deriva inicialmente de sua formação humanista, de sua predileção pela poesia greco-latina, se aproxima da arte verbal japonesa pela "concisão vocabular e estrutural inerente às duas situações" (idem), ao mesmo tempo que se avizinha dos procedimentos da vanguarda. A partir de Em tempo e memória, publicado em 1974, Albano Martins pratica uma escrita ainda mais concentrada, em consonância com as experiências construtivistas da época, desenvolvidas por poetas como Carlos de Oliveira em Micropaisagem (1969) e Haroldo de Campos em Lacunae (1969-1974) e Signância: quase céu (1979). Uma boa amostra

\footnotetext{
177 Paulo Leminski faz uma curiosa analogia a este respeito "Pela brevidade, o haicai guarda certo parentesco com o epigrama, a mais diminuta forma da poesia greco-latina, praticada no Ocidente durante o Renascimento e o Barroco" (LEMINSKI, 1983: 47), opinião compartilhada por José Fernando Castro
} 
da poética minimalista de Albano Martins encontra-se nestes fragmentos da terceira parte do poema Modulações:

3.

De inomináveis

obscuros,

refluentes

sinais

se tece

a polpa,

a medula

do espaço que habitamos.

*

O ritmo

do universo

cabe,

inteiro,

na pupila

dum verso.

Árvores

que me doem

na garganta

Quem as arranca?

Quem as planta?

Branco,

solúvel

veneno

ao rés

das pálpebras

arde

lento.

De lágrimas se molha

o tempo e a memória.

(MARTINS, 2000: 69-70).

Branco, para quem "se encontra no epigrama tudo o que de essencial caracteriza o haicai" (BRANCO, 2004: 51). 
Nesta composição, é notável o desenho sintático das palavras e frases, dispostas na página numa representação visual do movimento rítmico: "O ritmo / do universo / cabe, / inteiro, / na pupila / dum verso" (idem). Não há uma relação de continuidade referencial ou semântica entre as estrofes, que se combinam de acordo com o princípio da montagem ou superposição, como acontece na poesia japonesa. $\mathrm{O}$ elevado grau de abstração e subjetividade no poema de Albano Martins, no entanto, contrasta com a representação quase fotográfica do haicai, que busca o registro de paisagens e situações de contornos mais precisos - e recordemos aqui Haroldo de Campos, que no ensaio Visualidade e concisão na poesia japonesa afirma: "No pensamento por imagens do poeta japonês, o haicai funciona como uma espécie de objetiva portátil, apta a captar a realidade circundante e o mundo interior, e a convertê-los em matéria visível" (CAMPOS, 1977: 65). Albano Martins irá se aproximar desse princípio imagético/sensorial em outras seções da composição, como nesta pequena passagem:

Há folhas no tempo ainda verdes ainda à espera dum fictício verão.

(BRANCO, 2004: 72).

Neste micropoema construído com apenas onze palavras, a simplicidade das "folhas / no tempo / ainda verdes" e a ação inusitada da "espera" de um "fictício verão" recordam algumas peças de Bashô, como esta composição traduzida por Paulo Leminski: "templo de suma / ouvi a flauta não soprada / debaixo das árvores" (in LEMINSKI, 1983: 56). A representação da ausência, tão valorizada nas artes tradicionais japonesas, assim como os traços imprecisos, assimétricos ou inacabados na pintura, na poesia e na caligrafia serão elementos constantes na poesia de Albano Martins, que valoriza o espaço em 
branco da página, os cortes elípticos e o discurso paratático, em poemas cada vez mais condensados. A própria distribuição das palavras e linhas na página sugere a visualidade da escrita caligráfica, como acontece no poema Aproximações ao real:

Andaimes

para o vento:

nuvens.

*
Altas
e solitárias voam
as montanhas e as águias.

$*$

Pirilampos - acrí

licas vozes do sono.

Soltos ou não - quem pode vê-los? -,

de vento são os cabelos.

$*$

À laranja não

se lhe tira a casca,

mas o coração.

(BRANCO, 2004: 101).

Linhas breves, recortadas por sinais de pontuação e asteriscos, em que descobrimos nuvens e montanhas, águias e pirilampos, cabelos ao vento e laranjas descascadas, descritos com o mínimo de palavras, como se o poeta fosse um calígrafo japonês, que escreve o seu verso em rápidas pinceladas de nanquim sobre o papel. A concisão atinge o seu ponto máximo, talvez, neste poema de Sob os limos (1982):

De ciprestes

o templo

o tempo, 
o cálcio,

a cinza.

$*$

Certifico o silêncio,

a podridão do vidro.

Das casas

a ruína

sem ruído

(idem, 131-132)

A última estrofe - ou micropoema - da composição sugere uma referência intertextual a um dos mais conhecidos haicais de Bashô, o primeiro que comparece entremeado à prosa de sua narrativa de viagem Sendas de Oku: "a cabana de ervas secas / o mundo tudo muda / vira casa de bonecas" (in LEMINSKI, 1983: 10). A similaridade temática e de procedimentos com a poesia japonesa, porém, não derivava - neste momento - de um diálogo consciente com a arte de Bashô e seus amigos, que Albano Martins então desconhecia (em entrevista a Baptista-Bastos, o poeta declara: “... e se a minha poesia faz lembrar haicais japoneses, que todavia, é bom que se saiba, só tardiamente conheci, deixe-me lembrar-lhe que não são necessárias muitas palavras para dizer o amor, o deslumbramento, a paixão. Basta, às vezes, um oh!, um ah..." (BRANCO, 2004: 51-52). Somente em 1992, quando publica o livro Entre a cicuta e o mosto (1992), a forma do haicai aparecerá na obra poética de Albano Martins, como por exemplo nesta série de poemas:

\section{QUATRO QUARTETOS}

1.

Se houve um paraíso, foi depois, quando a maçã 
foi mordida.

2.

A cabeça da lua entre as coxas.

O sexo do luar.

3.

Solitários, solidários ambos - Hermes

e Afrodite.

4.

A um passo

da luz fulguram,

grávidas, as espadas.

A primeira composição do conjunto não descreve um movimento ocorrido nas dimensões do tempo e do espaço, mas remete a uma hipótese de passado, redesenhando o mito do pecado original como metáfora erótica - tema desenvolvido nas peças seguintes, especialmente a segunda, a mais concisa e imagética do conjunto: "A cabeça da lua / entre as coxas. / O sexo do luar”. Na terceira composição, aparecem personagens da mitologia greco-romana - Hermes e Afrodite $^{178}$ - que não participam de nenhum acontecimento, apenas expressam, simbolicamente, solidão e solidariedade. $\mathrm{O}$ último poema, com sua imagem das espadas brilhando sob o sol, é a que mais se aproxima da imagética nipônica, apesar da presença do adjetivo que transforma o objeto visível em metáfora, logo, em pensamento. Os quatro poemas breves desta série, embora escritos na forma do terceto (sem divisão métrica), não guardam nenhuma proximidade com o espírito do haicai, forma poética indissociável da experiência vivida no tempo e no espaço. O diálogo entre Albano Martins e a poesia japonesa atingirá

178 A mescla de referências na poesia de Albano Martins, como observou José Fernando Castro Branco, é capaz de conciliar "a ocidentalidade e a orientalidade, o espírito pagão e o espírito Zen" (BRANCO, 2004: 52). 
maturidade criativa no volume Com as flores do salgueiro, publicado em 1993, em homenagem ao tricentenário da morte de Bashô, que comparece já na epígrafe: “As cigarras cantam / sem saberem que é a morte / que as escuta". O livro, uma reunião de 48 poemas escritos na forma do terceto, sem métrica ou rimas (salvo exceções) e incluindo a referência sazonal - "Quando o verão / morre, as amoras / vestem-se de luto", por exemplo (MARTINS, 2000: 257) - apresenta motivos tradicionais da poesia japonesa, como a gaivota, o rouxinol, a rã, a libélula, a abelha e a montanha, e por vezes conversa com haicais do cânone clássico japonês, como acontece no poema de abertura - "Um mar azul / pintou de branco / o voo das gaivotas" (idem, 251), que responde ao haicai de Bashô "o mar escurece / a voz das gaivotas / quase branca” (in LEMINSKI, 1983: 36), numa inversão de luz e sombra.

Em outro poema, Albano Martins refabula a saga da rã: "Despida, à tona / da água, a rã / vê-se ao espelho" (idem, 254), desafio também aceito por Eugênio de Andrade e Casimiro de Brito, em suas incursões na micropoesia. A rima - inexistente na lírica japonesa - aparece poucas vezes nesse conjunto de poemas, e nunca de maneira ornamental ou puramente retórica; quando ela é empregada, reforça a intenção temática ou emotiva, como neste poema que recorda a delicadeza e o imaginário lúdico das crianças que caracterizam a poesia de Kobayashi Issa: “Castanha é a cor / do sorriso / do ouriço" (idem, 252). O olhar infantil acompanha diversas outras peças do livro, que nos fazem lembrar, por vezes, da simplicidade e da comunicação direta de um Mário Quintana, ele próprio um poeta de haicai: "A andorinha faz / a sua casa / no vento" (idem). As imagens raras, elemento destacado na poesia de Bashô e Buson, são abundantes no livro de Albano Martins: "Com as flores / do salgueiro / fez a água uma grinalda”, composição que faz referência à árvore mítica da poesia japonesa, o 
salgueiro. Uma outra imagem inusitada, agora construída num feitio quase teratológico: "Uma concha bivalve: / borboleta do mar, / de asas fechadas" (idem, 257).

A desmesura, elemento citado por Paulo Leminski como uma das características peculiares da poesia de Bashô, encontra, no livro de Albano Martins, exemplos como este: "Eclipse: a lua / joga às escondidas / com o sol” (idem, 258). A construção artificial e rebuscada de Teitoku, contraparte da simplicidade e objetividade de Soin, também comparece no volume, que não se prende a um único recurso ou estilo: “O insecto / pede à lâmpada / que lhe empreste os seus olhos" (idem, 260). Albano Martins experimenta várias possibilidades criativas na estrutura do terceto, sem temer o uso do paradoxo, do non sense e mesmo da imagem poética de feitio surrealista, como nesta composição, uma das mais belas do volume: "O rouxinol não sabe / que o seu canto / é verde" (idem, 253). A atribuição de características humanas a animais, a ideias ou objetos inanimados, recurso conhecido como prosopopeia, é cultivada em diversos haicais de Albano Martins, com uma fluência e aparente facilidade típicas da poesia de um outro brasileiro que, ao lado de Paulo Leminski, muito contribuiu para a divulgação do haicai em nosso idioma: Millôr Fernandes. Poemas como este: "Mais cedo ou mais tarde / o silêncio virá / perguntar por ti”"179, com o seu humor refinado e a incorporação crítica de expressões tiradas da linguagem cotidiana, encontram-se na mesma sintonia que as composições do poeta, cartunista e humorista brasileiro. A linguagem coloquial, longe de ser uma dissonância no repertório da poesia japonesa, retoma a liberdade formal e o despojamento da poesia de Bashô, que renunciou ao tom elevado e ao preciosismo da escola de Teitoku para incorporar a fala das ruas e a observação direta das coisas. Albano Martins, como observou José Fernando Castro Branco, não se limitou a seguir a divisão estrófica e métrica do haicai tradicional, mas buscou "o

\footnotetext{
${ }^{179}$ MARTINS, 2000: 262.
} 
instante poético, a anotação rápida de um momento privilegiado, a fixação do efêmero pela palavra justa em que, como afirma Paz, 'o instante é incomensurável'” (idem). 


\subsection{O branco no branco: a epifania de Eugênio de Andrade}

O crítico literário português Arnaldo Saraiva, ao enumerar as leituras que marcaram a formação literária de Eugênio de Andrade (1923), considera "quase obrigatório falar nos gregos (os elementos, o paganismo, o heraclitismo, a 'melancolia estoica' referida por Jorge de Sena), nos orientais (o haiku, o budismo zen) (...) e nos espanhóis da geração de 27, em especial Garcia Lorca" (SARAIVA, 2005: 22). Eugênio de Andrade recusou filiação a Presença, ao Surrealismo ou ao Neorrealismo e sua poesia sempre foi eclética e universalista, bebendo nas mais diversas fontes, aproximando-se da estética japonesa na concisão, brevidade, visualidade e sobretudo na epifania, como veremos no presente tópico. Desde os seus primeiros textos publicados, entre 1942 e 1945, Eugênio de Andrade praticou o poema breve, em especial a quadra, mas também composições com cinco, seis ou sete versos, como esta, intitulada Adágio: "O outono é isto - / apodrecer de um fruto / entre folhas esquecido. / Água escorrendo, / quem sabe donde, / ocasional e fria / e sem sentido" (ANDRADE, 2000: 14). Nesta notável composição não faltam a referência à estação do ano, a montagem cinematográfica, o mistério, a indeterminação e o paradoxo. O poema, escrito em meados da década de 1940, é provavelmente anterior à leitura de haicais japoneses por Eugênio de Andrade, o que nos faz pensar no caso de Alberto Caeiro, em que houve extraordinária afinidade temática e estética com a poesia japonesa, sem que houvesse uma relação intertextual planejada (tema estudado por Leyla Perrone-Moisés no livro Fernando Pessoa-Aquém do eu, além do outro). Eugênio de Andrade nunca foi um estudioso do haicai, como Wenceslau de Moraes ou Casimiro de Brito, nem um praticante sistemático dessa modalidade poética, mas encontramos poemas breves, inclusive na forma do terceto, em muitos de seus livros, como Ostinato rigore (1964), Obscuro domínio (1971), Véspera de água (1973), Matéria solar (1980), O outro nome da terra (1988), Rente ao dizer 
(1992) e Pequeno formato (1997). A homenagem explícita a Bashô aparece num curioso poema publicado, inicialmente, na antologia Uma rã que salta-Homenagem a Bashô (Porto: Limiar, 1995), organizada por Casimiro de Brito, que transcrevemos aqui:

\section{HOMENAGEM A BASHÔ}

As cigarras ardem nos ramos do verão como lenha verde.

Um rumor pueril e doce de abelhas enganava a sede.

No cimo da torre da praça mais branca é que o sol se despe, e dança dança dança. (BRITO, 1995: 22)

O primeiro terceto, fortemente imagético, com métrica próxima à redondilha menor (com versos de cinco e seis sílabas), inclui o signo da estação do ano, o kigo ("nos ramos do verão”) e o olhar do poeta está voltado às pequenas coisas da natureza, como cigarras e ramos de árvore, mostrados de maneira metafórica, que atribui um brilho virtuosístico à cena observada - “As cigarras ardem / (...) / como lenha verde”. No segundo terceto, permanece o foco nos seres de menor dimensão do reino animal, no caso, as abelhas, mas a objetividade do haicai é perdida com a adjetivação retórica (pueril, doce) e com a abstração metafórica da imagem. Na terceira composição, Eugênio de Andrade alcança maior precisão de imagens, nos dois versos iniciais, e conclui o poema com uma inesperada prosopopéia, em que o sol, convertido em personagem, despe-se da luz e "dança dança dança", sendo o quarto verso - inexistente no haicai - uma possível citação de Une saison en enfer, de Rimbaud ("Fome, sede, gritos, dança, dança, dança, dança", lemos na tradução de Ledo Ivo, in RIMBAUD, 
1982: 52). A cena criada por Eugênio de Andrade neste poema foge das convenções do haicai, mas, pela imagem inusitada, lúdica, próxima ao imaginário das crianças, não destoa da tradição inaugurada por Bashô, a quem o poema é dedicado no título. O apreço do poeta por esse pequeno conjunto de (quase) haicais pode ser avaliado por sua inclusão no livro Pequeno formato (1997), publicado por Eugênio de Andrade dois anos após o lançamento da antologia Uma rã que salta. A sensibilidade poética do autor, no entanto, submeteu os tercetos a uma rigorosa revisão estilística ${ }^{180}$, a começar pelo título, que muda para Rumores de verão, excluindo a óbvia referência intertextual do título anterior. O primeiro terceto, talvez o mais virtuosístico, foi reelaborado, perdendo um pouco do brilho original, porém ganhando maior proximidade com o espírito do haicai: "As cigarras cantam, / como no inverno / arde a lenha verde", imagem simples e eficaz, com economia de recursos e alta definição de contornos. Já o segundo terceto sofreu a alteração de uma única palavra, que mudou completamente o seu sentido: em lugar de "Um rumor pueril / e doce de abelhas / enganava a sede", o poeta escreve agora: "Um rumor pueril / e doce de abelhas / acrescenta a sede”, mudança imprevista que adiciona uma discreta ironia ao verso. A terceira estrofe muda completamente: em vez de "No cimo da torre / da praça mais branca / é que o sol se despe", o poeta escreve agora: "Quando o sol avista /os flancos do mar / despe-se a correr, / e dança dança dança" (ANDRADE, 2000: 545), substituindo a paisagem quase estática da versão anterior por uma imagem em movimento, que recorda a desmesura de uma composição de Bashô: "o dia em chamas / joga no mar / o rio mogâmi”, na tradução de Paulo Leminski ${ }^{181}$.

\footnotetext{
${ }^{180}$ Podemos recordar aqui da observação de Arnaldo Saraiva: "Eugênio de Andrade é, continua a ser, um poeta exigente e inconformado com os seus próprios poemas, que pode submeter a sucessivas e despudoradas emendas, e que publica com evidente parcimônia." (SARAIVA, 1995: 7) "Eugênio de Andrade não corrige apenas versões inéditas dos seus textos, pois transforma frequentemente em palimpsestos os seus textos éditos." (idem, 15)

${ }^{181}$ LEMINSKI, 1983: 51.
} 
Rumores de verão é a peça de abertura de Pequeno formato, conjunto de 30 poemas breves, em que predominam os dísticos, tercetos e quartetos; de todos os livros de Eugênio de Andrade, este é o que apresenta maior economia verbal. A simplicidade, a presença da natureza, dos animais e das quatro estações, a observação rara e as ações imprevistas, elementos característicos do haicai, predominam neste volume, embora poucas peças possam ser chamadas, a rigor, de haicais; talvez apenas o Jardim de Lou Lim Leoc, que diz: "Deste jardim o que levo comigo / é um ramo de bambu para servir / de espelho ao resto dos meus dias" (idem, 551), terceto antecedido pelo dístico intitulado Templo da barra: "O verde dos bambus mais altos é azul / ou então é o céu que pousa nos seus ramos" (idem). A imagética dessas composições é japonesa, sendo o bambu uma imagem recorrente na pintura sumiê e em diversos haicais, como neste poema de Buson, traduzido por Paulo Franchetti: “Com a luz do relâmpago / Barulho de pingos - / Orvalho nos bambus" (in FRANCHETTI, 2012: 100). A proximidade na página entre os dois poemas, um de três versos, o outro de dois versos, sem uma relação sintática ou referencial entre eles - com exceção da palavra bambu - remete ainda à forma do tanka, em que as duas estrofes têm certa autonomia, relacionando-se por analogia. A justaposição de sentenças sem um nexo lógico entre elas, à maneira de uma montagem cinematográfica, é um recurso estrutural da poesia japonesa, presente no tanka e também no haicai, como neste poema de Bashô: "Um corvo pousado / Num ramo seco - / Entardecer de outono" (idem, 128). Podemos encontrar vários exemplos dessa técnica nos poemas de Pequeno formato, como neste poema de cinco linhas, intitulado Cantam na madrugada: “À beira / d'água a luz / é em mim que tem morada: / tão longe / ainda a última barca" (ANDRADE, 2000: 553), em que há um claro corte entre os três primeiros versos e os dois seguintes, que se relacionam de maneira metafórica, assim como as estrofes de um tanka tradicional. A justaposição de cenas e 
ações simultâneas é ainda mais expressiva nessa quadra, intitulada Verão, escrita em versos de dez sílabas: "Era verão, pela varanda entrava / a madura ondulação do trigo, / o grito lancinante dos pavões, / o cavalo na sombra ardendo em cio" (ANDRADE, 2000: 547), em que não faltam o signo da estação do ano, os animais e vegetais integrados numa ordenação cósmica. A observação rara, frequente na poesia de Bashô, está presente em várias peças de Pequeno formato, especialmente na última composição do volume, intitulada À sombra de Victor Hugo, que é quase um oxímoro: "A sombra é sempre escura até mesmo / a dos cisnes" (ANDRADE, 2000: 554).

Além do "gosto das estruturas breves e simples, do poema, do verso, da frase" (SARAIVA: 1995, 38), encontramos na poesia de Eugênio de Andrade "as sonoridades cuidadas, os ritmos fluidos, a frase pontuada; o equilíbrio entre a simplicidade e o requinte da expressão (...); o apuramento dos sentidos; a revelação, a plenitude poética, o sentimento do tempo, o sentido do precário" (idem), elementos que estão em consonância com a arte poética japonesa, que valoriza especialmente a expressão sazonal, o vínculo entre o homem e a natureza, a imperfeição e a assimetria. Um outro aspecto da poesia de Eugênio de Andrade apontado por Arnaldo Saraiva e que merece especial atenção é a representação da epifania, palavra de origem grega (epi, sobre, phaino, brilhar) que o crítico português define como "uma luminosa manifestação, uma revelação clara e rara, uma clarividência essencial" (idem, 54). O conceito, de origem teológica, designava inicialmente "a manifestação ou o aparecimento divino no mundo ou a festa e o período que o celebra" (idem), como o nascimento de Cristo (caso em que o termo mais usado é teofania), aparições de santos ou outras entidades espirituais.

Mircea Eliade, em seu Tratado de história das religiões, define a epifania como “manifestação que lembra ou se parece com uma manifestação divina, uma experiência exaltante e inesperada, o súbito acesso a um conhecimento ou prazer essencial, a 
percepção nítida de uma verdade imprevista, um momento de inteligência global do real" (in SARAIVA, 1995: 53), como por exemplo as revelações obtidas em sonhos, transes xamânicos, experiências com alucinógenos místicos ou a iluminação zenbudista. Conforme observa Arnaldo Saraiva, o conceito de epifania passou a ser empregado, na modernidade, por autores como James Joyce, num contexto laico e profano, para designar experiências estéticas de revelação e deslumbramento “perceptíveis pelos ou por alguns dos sentidos; não é uma experiência duradoura - é uma experiência intervalar e efêmera, salva na memória” (idem, 54). A poesia de Eugênio de Andrade revela "diversas modalidades epifânicas ou diversos tipos de narrativa epifânica", escreve Arnaldo Saraiva (idem, 55). No poema Sul, que integra o volume $O$ outro nome da terra, por exemplo, o poeta diz:

Era verão, havia o muro.

Na praça, a única evidência

eram os pombos, o ardor

da cal. De repente,

o silêncio sacudia as crinas,

correu para o mar.

Pensei: devíamos morrer assim.

Assim: explodir no ar

(ANDRADE, 2000: 451-452)

Nesta composição de oito versos, sem medida métrica nem divisão estrófica, o poeta "documenta bem a passagem de um tempo e modo comum e concreto (verão, muro, praça, pombos, cal) para um tempo e modo epifânicos, que sem abolir a visão ou 'evidência' objetiva ('assim') implica, sobretudo, uma evidência, uma clarividência relativa ao sentimento ou ao pensamento escatológico" (SARAIVA, 2005: 56), o que acontece nas linhas finais do poema ("Pensei: devíamos morrer assim. / Assim: explodir no ar”). Em outro poema breve de Eugênio de Andrade, incluído em Pequeno formato, o registro epifânico é menos dramático que lírico: 


\section{COMO NO INÍCIO}

É a noite por fim, podes tocá-la.

Também a mão, a pequena e febril

música da mão, aí está a iluminá-la.

Agora vê-se melhor o caminho.

(in ANDRADE, 2000: 550)

A paisagem metafórica do poema, em que não falta o recurso da sinestesia (“É a noite por fim, podes tocá-la”), prescinde de um sujeito identificável; há um enunciador que descreve a sucessão de imagens e um interlocutor a quem esse discurso visual é transmitido, mas ambos permanecem quase invisíveis no poema, sem nada que os identifique além da própria enunciação. A epifania acontece no próprio discurso, em que elementos simples como a noite, a mão e a música se transfiguram para iluminar o caminho, que é trajeto, revelação e descoberta (podemos recordar aqui o ideograma chinês que representa o Tao, que significa, ao mesmo tempo, o caminhante, o caminho e o ato de caminhar). Conforme observa Arnaldo Saraiva:

o fenômeno epifânico é sempre relacionável com o sujeito enunciador do poema, que interessadamente o assinala e acusa os seus efeitos, às vezes dentro do seu próprio corpo ('subitamente como fonte ou ave / rompe dentro de mim); mas ele também pode implicar e afetar outros seres, árvores, bichos, a terra, o ar e até os nomes.

(idem, 57-58).

Nesta acepção, podemos relacionar o conceito de epifania com a experiência espiritual indissociável da prática do haicai, tal como compreendida por Bashô. Comentando o poema da rã, Alberto Marsicano escreve em sua introdução a Trilha estreita ao confim, que reúne os quatro principais diários de viagem do mestre japonês:

Bashô contemplou num harmonioso entardecer uma tranquila lagoa quando uma rã saltando sobre a água rompeu subitamente a lisa superfície. Não com um forte ruído mas com um som claro e distinto. Ao ouvir este som cristalino o poema fluiu quase que involuntariamente leve e simples, sem artifício algum. O haicai é o olho do furacão, o profundo toque de um gongo de bronze, o iridescente relâmpago que inesperadamente reluz na escuridão da noite. o haicai é o satori, o despertar zen que repentinamente surge no caminho.

ao sol da manhã

uma gota de orvalho 
precioso diamante

(in Bashô: 1997, 11)

A experiência do satori (悟り), referida por Alberto Marsicano, é o objetivo central da prática zen-budista: a tomada de consciência do vazio original da mente (sunyata, em sânscrito) e a superação da percepção dualista que nos aprisiona ao mundo fenomênico $^{182}$. Como toda vivência espiritual profunda (os êxtases místicos de São João da Cruz ou de Santa Teresa de Ávila, na tradição cristã, ou a vivência do sagrado em Rumi e Attar, na tradição sufi), o satori não pode ser descrito em palavras; segundo Paulo Leminski, é algo "pessoal e intransferível, impossível de programar, prever ou administrar (o desejo de atingir a iluminação, inclusive, dizem, é o maior obstáculo para atingi-la)" (LEMINSKI, 1983: 68). Apesar da impossibilidade de se registrar na forma escrita as sensações e percepções da jornada espiritual, existe vasta literatura sobre o assunto, desde interpretações filosóficas ou teológicas da vivência mística até poemas, cartas ou relatos em prosa que de certa forma "transmitem" algo dessa experiência. Segundo relatos dos antigos historiadores chineses, técnicas indianas de meditação (dhyana, em sânscrito; ch'an, em chinês; zen, em japonês) foram introduzidas na China desde o século II a. C. por Bodhidarma, o primeiro patriarca do zen-budismo, e de lá foram levadas para a Coreia, o Tibete e o Japão, mesclando-se a tradições locais como o taoísmo, o xintoísmo, o confucionismo, cultos devocionais e práticas mágicas ou

\footnotetext{
${ }^{182}$ No livro de poemas Satori, de Horácio Costa, publicado em 1989, Severo Sarduy, que assina o prefácio do volume, faz uma reinterpretação do conceito, sob uma ótica ocidental laica: "O prólogo do satori é não só a vida inteira, toda a realidade, mas também as existências anteriores, míticas, sonhadas pelo sujeito ou por essa alucinação persistente que considera como seu 'eu'. Desses estados preparatórios só tem uma vaga consciência no sonho - na sucessão de imagens ao mesmo tempo prismáticas e desalinhavadas do sonho - na escritura - o Diário esquecido e hoje recuperado convoca por si próprio, como um animal agradecido, expulso e aceito de volta, um éden das palavras, uma utopia verbal - e no amor - nesse Outro nos dissolvemos, até atingir como que um apagar da individualidade, o anonimato genético. Se estes três estados, sonho, amor e escritura, nos fazem vislumbrar o estado absoluto do satori, é porque neles a linguagem também se encontra em condição de precariedade: no sonho porque constitui, desconexa, precisamente sua matéria, sua madeira; na escritura porque se trata, antes de mais nada, de captar seu surgimento, de presenciar sua epifania ou sua retração; no amor porque sua luz zenital, ou seu êxtase, excluem-na por definição. A linguagem do satori é, como o esboça a destes três âmbitos, a que circunscreve o indizível, brusca agrimensura do não-verbal”. (COSTA, 1989: 9)
} 
esotéricas. O mestre mais reverenciado da tradição zen-budista é Hui-Neng, que teria ensinado no século VI no Mosteiro da Ameixa Amarela. A respeito deste sábio chinês escreve Paulo Leminski:

A assim chamada Doutrina Lanka de Bodhidarma foi transmitida por muitas gerações a Hui-Neng, homem de origem humilde, um lenhador analfabeto, ideias revolucionárias e duradoura influência. Nascido em Fan-Yang, a sudoeste de Pequim, Hui-Neng perdeu o pai muito cedo. E levava vida penosa, sustentando a mãe como apanhador e vendedor de lenha.

Aos vinte e quatro anos, vendendo lenha na cidade, ouviu alguém recitando o Sutra do Diamante, uma das escrituras hindus traduzidas para o chinês. Hui-Neng quis saber mais. Enviado a Hupei, submeteu-se à direção de Hung-Jen, o quinto patriarca, tornou-se monge e acabou superior do mosteiro Fa-Hsing, recebendo a dignidade de patriarca das mãos do próprio Hung-Jen.

Esta transmissão do patriarcado consistia na entrega do manto pessoal e da tigela de pedir esmolas.

Atuou por trinta e sete anos, atraindo os mais famosos mestres Zen da época, incluindo os quarenta e três "herdeiros da lei", que disseminaram seus ensinamentos por toda a China, o Sudoeste Asiático, a Coreia e o Japão.

Do pensamento de Hui-Neng, chegou-nos um texto, “A Escritura Plataforma”, sermão pronunciado pelo sexto patriarca, no mosteiro Tan-fan.

De Hui-Neng descendem, espiritualmente, Bashô e seu haicai, bem como as artes zen, das quais o haicai se alimentou (idem, 78-79).

Mestres budistas comparavam a mente humana a um espelho, cuja essência é pura e perfeita. Ao entrar em contato com o mundo material, a superfície cristalina acumula poeira, que recobre a sua pureza original. Shen-hsiu escreveu o seguinte poema, para apresentar o conceito: "Este corpo é a árvore Bodhi / a mente é como um espelho iluminado; / Empenhai-vos em mantê-la sempre limpa / Sem deixar que nela se junte o pó” (in SUZUKI, 1993: 15). Para "limpar a mente” dos resíduos mundanos e fazer com que ela recupere a sua natureza de puro cristal, Shen-hsiu propunha o "método gradual" para a iluminação, que incluía o estudo dos Preceitos morais (sila), Meditação (dhyana) e Sabedoria Transcendental (prajna) ${ }^{183}$, tópicos que integravam a vida monástica na

183 “A moralidade consiste em observar todos os preceitos estabelecidos por Buda, tendo em vista o progresso espiritual de seus discípulos; a meditação é o exercício destinado ao treinamento pessoal na 
maioria das escolas budistas, tanto as do sul quanto as do norte da China. Rebelando-se contra o formalismo das práticas meditativas, o quietismo e sobretudo contra a ideia de uma evolução espiritual gradual, Hui-Neng apresentou o seguinte poema, em resposta ao de Shen-hsiu: "Não há árvore Bodhi, / nem o cessar do brilho do espelho. Sendo tudo vazio, onde / poderia assentar-se o pó?”. A natureza búdica da mente, para Hui-Neng, “não persiste nem é aniquilada; não chega nem parte; não está no meio nem nas extremidades; ela não morre nem nasce. Permanece a mesma o tempo todo, imutável em todas as mudanças. Assim como nunca nasceu, nunca morrerá" (idem, 33). O "método abrupto" de Hui-Neng não era a "arte de tranquilizar a mente para que sua essência interior, pura e imaculada, pudesse extravasar os seus invólucros” (idem), uma vez que ela já é "pura, simples e iluminadora como o sol por trás das nuvens” (idem, 22). O reconhecimento desse princípio, para o sábio chinês, era a iluminação súbita, que dispensava erudição, práticas de austeridades ou rigor nas normas cerimoniais e de conduta. A busca do satori tornou-se o centro da vivência zen-budista, e os meios para esse súbito despertar eram os mais inusitados, podendo incluir desde tarefas domésticas, como varrer o templo, até golpes de bambu aplicados pelo mestre no discípulo ou histórias absurdas ou enigmáticas (koans), como esta, relatada por Paulo Leminski:

Hui-Ko procurou Bodhidarma, primeiro patriarca do zen chinês, e lhe disse:

— Não tenho paz na minha mente. Pacifica a minha mente.

tranquilização, pois se a mente não for controlada pela meditação, de nada adiantará observar mecanicamente as regras de conduta; na realidade, estas se destinam a tranqüilizar o espírito. Sabedoria ou prajna é o poder de penetrar a natureza do próprio ser (...). Não é preciso dizer que todas essas três disciplinas são necessárias a um budista sincero. Mas, com o passar do tempo, depois de Buda, a Tríplice Disciplina cindiu-se em três ramos distintos de estudo: os seguidores das regras de moralidade estabelecidas pelo Buda tornaram-se professores do Vinaya; os yogues da meditação incorporaram-se a várias espécies de Samadhi e até mesmo adquiriram algumas faculdades extraordinárias (...). E finalmente, os que buscavam Prajna tornaram-se filósofos dialéticos ou líderes intelectuais. Esse estudo unilateral da Tríplice Disciplina fez com que os budistas se desviassem do reto caminho da vida budista, especialmente quanto a Dhyana (meditação) e a Prajna (sabedoria ou conhecimento intuitivo)." (SUZUKI, 1993: 30) 
— Traz tua mente à minha presença e eu a pacifico, responde Bodhidarma.

— Mas quando busco a minha própria mente, não consigo encontrá-la, diz Hui-Ko.

E Bodhidarma:

— Pronto! Pacifiquei tua mente.

(LEMINSKI, 1983: 73)

A vivência profunda da espiritualidade zen-budista está presente na poesia de Bashô, e ainda na maneira como ele ensinava os seus discípulos, como podemos verificar nestes aforismos do poeta japonês, que abandonou o caminho do samurai após a morte de seu mestre para tornar-se monge andarilho:

Repita seu verso mil vezes nos lábios.

Não siga os antigos. Procure o que eles procuravam.

Respeite as regras. Então, jogue todas fora. Pela primeira vez, você atinge a liberdade. (in LEMINSKI, 1983: 41-42)

Aprende do pinheiro diretamente do pinheiro; do bambu, diretamente do bambu.

(BASHÔ, 1997: 10)

Eugênio de Andrade, em outro momento histórico, outra dimensão geográfica e com outro repertório cultural, aproxima-se, pelo conceito laico (e mesmo pagão) da epifania - "uma luminosa manifestação, uma revelação clara e rara, uma clarividência essencial" (SARAIVA, 1995: 54) da experiência zen-budista. No prefácio à sua Antologia breve (Lisboa: Moraes Editores, 1980), o poeta português define o ato poético como "o empenho total do ser para a sua revelação", que ele define como a "descida ao coração da alma, essa coragem de mostrar o que achou no caminho", que caracterizaria "a dignidade do poeta e, com ela, a do homem" (ANDRADE, 1980: 7-8). A tarefa do poeta seria resistir à "desfiguração" imposta pela cultura moderna e resgatar o rosto original do homem, "belo e tenebroso, à luz limpa do dia" (idem). Enumerando poetas e místicos de diferentes épocas, culturas e países que considera seus companheiros de 
jornada, Eugênio de Andrade escreve: "De Homero a S. João da Cruz, de Virgílio a Alexandre Blok, de Li Po a William Blake, de Bashô a Cavafys, a ambição maior do fazer poético foi sempre a mesma: Ecce Homo, parece dizer cada poema. Eis o homem, eis o seu efêmero rosto" (idem, 8-9). A rebelião do poeta seria feita "em nome dessa fidelidade. Fidelidade ao homem e à sua lúcida esperança de sê-lo inteiramente; fidelidade à terra onde mergulha as raízes mais fundas; fidelidade à palavra que no homem é capaz da verdade última do sangue, que é também verdade da alma" (idem, 9). A tonalidade desta breve nota é a de um manifesto, em que não são poucas as referências românticas, como a oposição entre cultura e natureza, a busca de uma verdade essencial, a valorização da sinceridade e da expressão subjetiva, e mesmo o emprego de palavras como rebelião, raízes, terra, sangue, alma. O poeta é visto de modo messiânico, como aquele que possui as chaves mágicas para decifrar a realidade e mostrar ao homem o seu próprio rosto.

O pensamento filosófico de Eugênio de Andrade possui diversos matizes que contrastam com as percepções de Matsuo Bashô - único oriental citado entre os seus poetas de devoção, ao lado do chinês Li T'ai Po - mas podemos estabelecer uma relação elucidativa entre a perspectiva idealista do autor português e a visão sincrética do poeta samurai, que recebeu a educação militar e cultural adequada a um guerreiro (que incluía aulas de pintura, poesia, caligrafia e filosofia, além do treinamento no manejo de armas), absorveu as normas de conduta confucianas e depois abraçou a mística budista, sem nunca perder um vínculo espiritual com a natureza, herança da cosmovisão xintoísta, presente em todas as manifestações da arte japonesa. Eugênio de Andrade, assim como o poeta-samurai, também recebeu treinamento militar, expressou o sentimento de vínculo com a aldeia natal e manteve sempre a referência à natureza em seus poemas, numa perspectiva espiritual humanista e próxima ao panteísmo. O diálogo 
consciente que Eugênio de Andrade estabeleceu com o haicai, no entanto, foi acima de tudo estético, e ele não renunciou a sua própria linguagem poética, pouco afeita ao humor e ao coloquialismo, para glosar a irreverência de Bashô ("Pulgas piolhos / um cavalo mija / do lado do meu travesseiro", na tradução de Paulo Leminski ${ }^{184}$; "Sem nada, ainda piolhos / da minha viagem passeiam / no estival quimono", na versão de Jorge de Sena ${ }^{185}$ ). A afinidade espiritual entre os dois poetas, podemos formular esta hipótese, aconteceu sobretudo na relação com a terra, os animais, as aves e os peixes; a mística do Eugênio de Andrade, assim como a de Bashô, não se situa num plano transcendental, numa zona etérea além das dimensões do espaço e do tempo, mas, ao contrário, ela acontece aqui e agora, em nossa relação com as estações, paisagens, pessoas e objetos. Conforme observou Arnaldo Saraiva, o poeta português "soube ainda revitalizar o veio do chamado lirismo tradicional, inventando um ruralismo e um bucolismo" (SARAIVA, 1995: 22). Sua maneira de olhar para as coisas era quase fotográfica, extraindo o lirismo possível dos objetos tangíveis. Eugênio de Andrade recorre por vezes à alegoria e à metáfora, "mas nem por isso elas deixam de revelar um fulgor concreto e objetivo que só lhes podia conferir a experiência concreta do mundo (empírico), feita em lugares (concretos) que quase nunca são diretamente nomeados" (idem, 37), embora saibamos, pela biografia do poeta e algumas referências históricas e geográficas, a quais cidades ele em geral se refira, como Povoa, Lisboa, Tavira, Porto ou Coimbra - assim como Bashô mapeou o seu percurso como poeta-andarilho em seus diários de viagem, especialmente Sendas de $O k u$, redigido quatro séculos antes do nascimento do autor português. A rã de Bashô ressoa na lírica de Eugênio de Andrade, viajando no espaço e no tempo, transformada em outros batráquios, como vemos neste

\footnotetext{
${ }^{184}$ BASHÔ, 1983: 52.

${ }^{185}$ In SENA, 1972: 13.
} 
Noturno: "Coaxar de rãs é toda a melodia / que a noite tem no seio / - versos dos charcos / e dos juncos podres / casualmente, com luar no meio" (ANDRADE, 2000: 98). 


\subsection{A rocha vermelha de Yvette Centeno}

Yvette Centeno (1940) poeta, ensaísta e tradutora portuguesa, é estudiosa da obra de Fernando Pessoa e pesquisa temas relacionados com a maçonaria e o hermetismo. Sua tese de doutorado é sobre A alquimia no Fausto de Goethe e a autora criou o Gabinete de Estudos de Simbologia da Universidade Nova de Lisboa, onde leciona. A obra publicada de Yvette Centeno inclui romances como No jardim das nogueiras (1982), peças teatrais -- Saudades do paraíso (1980), Será Deus o dr. Freud? (1995), ensaios - Fernando Pessoa: tempo, solidão, hermetismo (1978), A utopia: mitos e formas (1994) e coletâneas de poesia, como A Oriente (1998), em que dialoga com a estética japonesa e a forma do haicai, como estudaremos no presente tópico. A autora, que também traduziu poetas como Bertolt Brecht e Paul Celan, mantém o blog Simbologia e alquimia (http://simbologiaealquimia.blogspot.com.br/), onde publica regularmente textos sobre literatura, mística e psicanálise. Yvette Centeno participou das principais antologias de haicai publicadas em Portugal - entre elas Uma rã que salta - Homenagem a Bashô, organizada por Casimiro de Brito (Porto: ed. Limiar, 1995) e De frente para o mar, de David Rodrigues (Coimbra: Palimage, 2010), para citar as mais recentes. Seu

Em Uma rã que salta, Yvette Centeno publicou uma notável série de doze haicais, com o título de Renga (hokku de Os 64 trigramas com waki de Stephen Reckert). Conforme vimos no primeiro capítulo, a renga é um gênero poético em que participam dois ou mais poetas que desenvolvem um ciclo de poemas encadeados, sem um nexo lógico entre as partes. No caso da poeta portuguesa, ela dialoga com o catedrático norteamericano Stephen Reckert (1923-2013), especialista em literatura portuguesa e espanhola e também estudioso da poesia japonesa. Yvette Centeno escreveu os tercetos (hokku), em português, acompanhados por dísticos (waki) de Reckert em espanhol, 
inglês, italiano, francês e português, numa voluntária babel de idiomas e referências literárias e culturais. Todos os poemas são escritos em caixa baixa (na escrita japonesa não há maiúsculas ou minúsculas), sem métrica, rimas ou pontuação; o signo da estação do ano (kigo) comparece em boa parte das composições, ainda que de maneira não convencional, como nesta curiosa peça, que dialoga também com o conhecido poema de Bashô: "jazz em agosto / cantam as rãs / mirando-se no lago / dans les allées, les statues / impassibles" (in BRITO, 1995: 26). Referências musicais não faltam na poesia de Bashô, como nos haicais "começo da poesia / o canto dos plantadores de arroz / desta

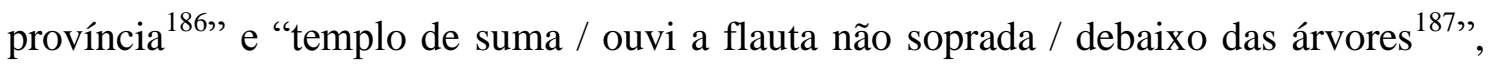
traduzidos por Paulo Leminski (assim como há referências diretas à pintura e ao teatro nô, que faziam parte do repertório cultural dos samurais). Yvette Centeno incorpora a música ao poema com ironia, mesclando o jazz ocidental ao coaxar das rãs, elevado ao nível do canto. Há também o contraste nítido entre a ação que acontece no poema e a impassibilidade das estátuas, no dístico escrito em francês. Em apenas cinco linhas, há todo um palimpsesto de referências simbólicas, sem exclusão da possível leitura psicanalítica (na duplicidade das rãs, refletidas no lago). O caráter intelectual do poema destoa, sensivelmente, da criação espontânea preconizada por Bashô a seus discípulos; podemos considerar, no entanto, que este é um fenômeno inevitável na poesia ocidental, especialmente a partir das primeiras décadas do século $\mathrm{XX}$, com a eclosão das vanguardas, que colocaram a reflexão metalinguística como tema principal da poesia.

No livro A Oriente, publicado em 1998, Yvette Centeno reúne uma expressiva coleção de oitenta haicais ${ }^{188}$, numerados e sem títulos, juntamente com outros poemas

\footnotetext{
${ }^{186}$ LEMINSKI, 1983: 42.

${ }^{187}$ LEMINSKI, 1983: 56.

${ }^{188}$ Os haicais de A Oriente são dedicados pela autora a Dídia e Stephen Reckert.
} 
breves, escritos em português e em francês, escritos numa dicção concisa e elíptica que não se filia a nenhum movimento ou escola, mas têm certa proximidade com o experimentalismo de Ana Hatherly e E. M. de Melo e Castro (“A transgressão: esse é o meu limite ${ }^{189}$,, diz um poema sem título do volume, composto de uma única linha). A epígrafe do caderno de haicais é um poema de Issa, traduzido pelo brasileiro Paulo

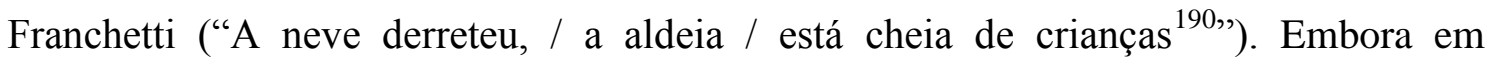
algumas composições a autora portuguesa se aproxime da simplicidade do autor japonês

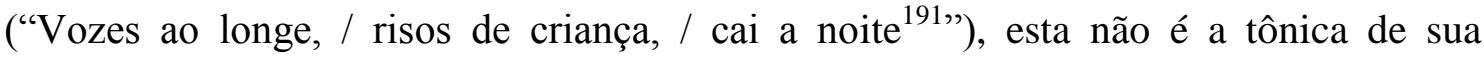
produção, em que se destacam metáforas ("Rocha vermelha: / um coração a pique / sobre o mar ${ }^{192 »), ~ i m a g e n s ~ r a r a s ~(" D e ~ m a d r u g a d a, ~ / ~ o ~ p e s o ~ d o ~ l a g a r t o ~ / ~ a g a r r a d o ~ a ̀ ~}$ cabeça ${ }^{193 » "), ~ a c ̧ o ̃ e s ~ i m p o s s i ́ v e i s ~(“ A g a r r a r ~ a ~ L u a ~ / ~ e ~ a t i r a ́-l a ~ / ~ a o ~ m a r ? ~}{ }^{194 » ”), ~ f e n o ̂ m e n o s ~ d a ~}$ natureza (“Águas bravas, / rochedos, / covas onde se encalha ${ }^{195 ”), ~ a n a ́ f o r a s ~(“ A s ~ c o p a s ~}$

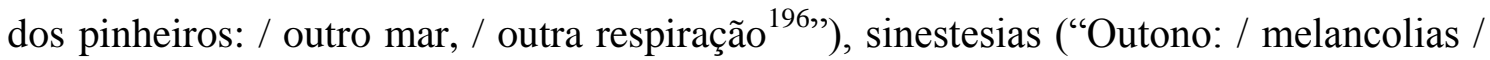
pesadas $^{197, ") ~ a n g u ́ s t i a ~ e x i s t e n c i a l ~(" R e m e x e n d o ~ p a p e i s, ~ / ~ q u e ~ f o r m a ~ / ~ d e ~ m o r r e r ~}{ }^{198 »), ~ o ~}$

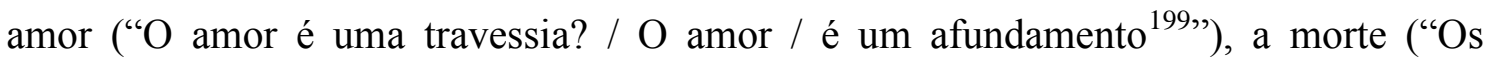

\footnotetext{
${ }^{189}$ CENTENO, 1998: 16.

${ }^{190}$ Idem, 37.

${ }^{191}$ Idem, 41.

${ }^{192}$ Idem, 49.

${ }^{193}$ Idem, 44.

${ }^{194}$ Idem, 59.

${ }^{195}$ Idem, 68.

${ }^{196}$ Idem, 41.

${ }^{197}$ Idem, 50.

${ }^{198}$ Idem, 59.

${ }^{199}$ Idem, 77.
} 
retratos na mesa: / mortos e vivos / sorrindo lado a lado ${ }^{200 "), ~ o ~ s o n h o ~(" N o ~ s o n h o, ~ / ~ o ~}$ negro matador / com o seu punhal ${ }^{201 ")}$ ) aliados à extrema concisão (“A morte: / lento apertar / da teia ${ }^{202 »)}$ e à reflexão metalingüística (“A palavra: / libertação ou /

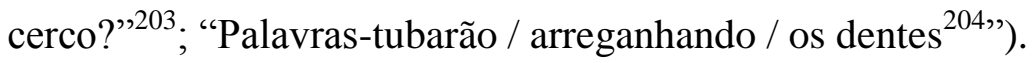

A pesquisa de Yvette Centeno no campo da filosofia hermética e da alquimia pode sugerir algum vínculo entre essas formas de representação simbólica e sua lírica, hipótese que não descartamos, mas que não parece ser um elemento axial em sua criação. A mitologia grega está explícita em pelo menos duas composições: "Três

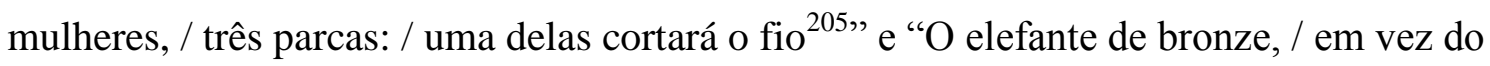

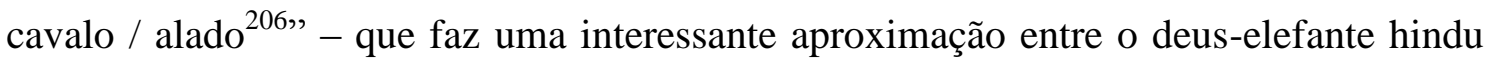
Ganesha (que teria escrito o Mahabharata com uma de suas presas de marfim) e o Pégaso helênico. A integração entre céu, homem e terra, base da filosofia taoísta e do zen-budismo, é verificável em vários de seus haicais, como por exemplo nesta peça: “O suspiro do homem / no alto / da colina ${ }^{207, ", ~ q u e ~ r e c o r d a ~ a i n d a ~ o ~ s e n t i m e n t o ~ d e ~ s o l i d a ̃ o ~ d o ~}$ eremita (sabi), representado em pinturas e poemas. Despojamento, simplicidade, leveza e melancolia são outras características desse terceto, que guarda proximidade temática com outra peça: "Subir ao monte / contemplar / a descida"208". As montanhas, representadas em diversas pinturas chinesas e japonesas (nessas últimas, se destaca o

\footnotetext{
${ }^{200}$ Idem, 65.

${ }^{201}$ Idem, 43.

${ }^{202}$ Idem, 44.

${ }^{203}$ Idem, 39.

${ }^{204}$ Idem, 71.

${ }^{205}$ Idem, 45.

${ }^{206}$ Idem, 53.

${ }^{207}$ Idem, 66.
} 
monte Fuji, tema de diversos haicais), eram não apenas locais de mosteiros e eremitérios, mas também símbolos da jornada espiritual (escalar uma montanha, muitas vezes, é a metáfora do caminho que um neófito budista deve trilhar para atingir a iluminação, tema abordado na poesia de Han Shan). A descrição de cenas do cotidiano, elemento presente no haicai tradicional, encontra-se também neste ciclo de poemas de Yvette Centeno, como nessa composição, de extrema delicadeza e simplicidade: "Anoitecer de Setembro / um casal abraçado / na varanda", que recorda a pintura hiperrealista de Hopper. A diversidade temática e estilística de Yvette Centeno, que navega entre o diálogo com a tradição (ocidental e oriental) e o imprevisto, mesclando referências de diferentes territórios culturais com agudeza e sensibilidade, situa a autora entre as vozes mais originais e consistentes da poesia portuguesa contemporânea.

${ }^{208}$ Idem, 72. 


\subsection{O cenário atual: três antologias}

Uma rã que salta - Homenagem a Bashô (Porto: Limiar, 1995), já referido neste capítulo, é um elegante volume que apresenta traduções e poemas originais que dialogam com o mais conhecido de todos os haicais japoneses - "No velho tanque / uma rã salta - mergulha. / Ruído na água"209, de Bashô. A antologia, organizada por Casimiro de Brito para o Pen Club português, apresenta ensaio introdutório do estudioso inglês Stephen Reckert, professor da Universidade de Londres e autor de Beyond Chrysanthemus (Oxford Press, 1993), e poemas escritos por vinte autores de língua portuguesa, entre eles Eugênio de Andrade (1923-2005), Antonio Ramos Rosa (19242013), Albano Martins (n. 1930), Yvette Centeno (n. 1940), Maria Alzira Seixo (1941) e o brasileiro Murilo Mendes (1901-1975). No final do volume, foi incluído um caderno com traduções de Bashô realizadas por outros nomes de importância na literatura portuguesa, como Jorge de Sena (1919-1978), Ana Hatherly (n. 1929) e Liberto Cruz (1935), e ainda dos brasileiros Paulo Franchetti (1954) e Elsa Taeko Doi. A leitura atenta desta antologia revela enorme diversidade de dicções e estilos, que dialogam de maneira criativa com temas e técnicas da poesia japonesa tradicional, sem intenção caricatural ou mimética. Esta antologia, pioneira no cenário literário de Portugal, estimulou o surgimento de duas outras coletâneas, que comentaremos a seguir.

De frente para o mar (Coimbra: Palimage, 2010), obra organizada por David Rodrigues, é uma reunião de poemas de dez autores portugueses, incluindo desde nomes incorporados ao cânone, como Casimiro de Brito e Albano Martins, até autores mais recentes, como Luís Domingos (1953) e Lucília Saraiva (1966). A pluralidade e diversidade de vozes elencadas no volume, conforme escreve o organizador, reflete a vitalidade de um gênero poético cada vez mais praticado no Ocidente e no Oriente:

\footnotetext{
${ }^{209}$ BRITO, 1995: 19.
} 
A poesia haiku, com a sua postura não didática, centrada no momento e no presente, frugal na expressão e ligada à Natureza constitui uma afirmação de valores que vão contra-corrente dos valores hodiernos da comunicação pessoal e social e da vida quotidiana das sociedades industrializadas. Assim, escrever haiku não é linearmente equivalente a escrever qualquer outro tipo de poesia: pressupõe - como dizia um dos seus maiores cultores, Matsuo Bashô - a procura de um caminho de valores, uma via de transformação pessoal que aproxima o caminhante de uma visão do mundo da qual emerge a atitude e a escrita haiku. Um caminho pessoal de despojamento e de procura do essencial. Um haiku procura o que designa no Japão como haim, o que poderia ser traduzido como "o sabor do haiku", uma qualidade que, como afirma o poeta japonês Ban'ya Natsuishi, é um mistério que não pode ser explicado mas que pode ser compreendido. O poeta brasileiro Manuel Bandeira dizia, sobre o haiku, evocando a marca da sutileza que esta poesia tem, que se trata de "estremecimentos, murmúrios ou rastros de perfume".

(RODRIGUES: 8, 2010)

Neste pequeno (e denso) registro de vozes, encontramos poetas que privilegiam os aspectos mais lúdicos e bem-humorados do haicai, como Albano Martins ("Peixes: os sobreviventes / dos antigos / naufrágios ${ }^{210 " ; ~ " P o r q u e ~ e ́ ~ q u e ~ o s ~ p e i x e s ~ / ~ d o r m e m ~ / ~ d e ~}$ olhos abertos? ${ }^{211 ")}$ e Lécio Ferreira (“atrás das rochas / sem saber que é visto / o velho

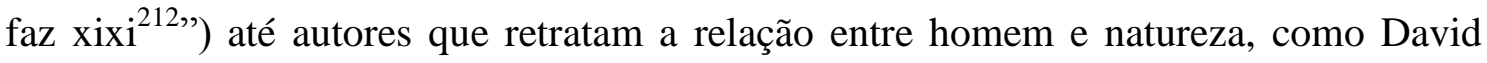
Rodrigues (“graves, na duna / eu e uma lagartixa / olhamos o mar"213") e Dinis Lapa

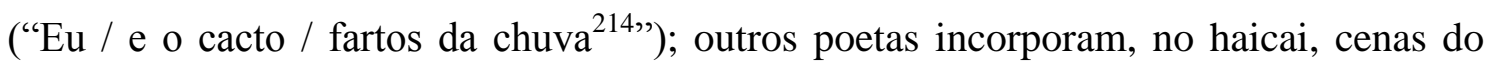
mundo contemporâneo, como Casimiro de Brito ("Um petroleiro! / No mar também habitam / animais doentes ${ }^{215 ")}$ e Lucília Saraiva ("no que resta da praia - / inerte, / um

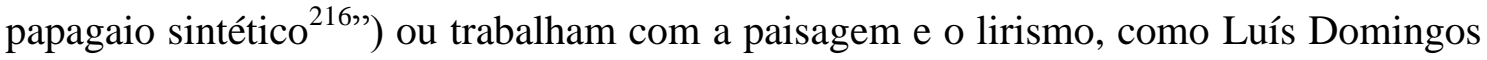

\footnotetext{
${ }^{210}$ Rodrigues, 2010: 18 .

${ }^{211}$ Idem, 19.

${ }^{212}$ Idem, 78.

${ }^{213}$ Idem, 44.

${ }^{214}$ Idem, 63.

${ }^{215}$ Idem, 35.

${ }^{216}$ Idem, 119.
} 


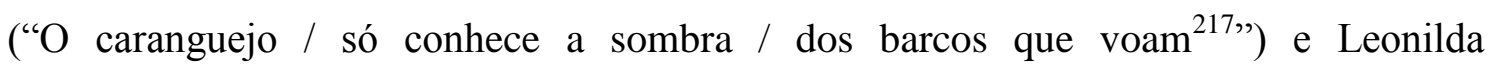
Alfarrobinha ("crescem flores bravas / no penhasco de ninguém -- / só a voz do $\operatorname{mar}^{218 »)}$. Uma voz que se destaca em De frente para o mar é a de Liberto Cruz (1935), que foi conselheiro cultural da embaixada portuguesa na França e diretor da Fundação Oriente, em Lisboa, autor de livros como Caderno de encargos e Sequências (ambos de 2000). Sua poética é concisa, elíptica, substantiva, deslocando a atenção da paisagem e da emoção lírica para a materialidade do poema, numa dicção entre a "faca só lâmina" de João Cabral de Melo Neto e o sabre de aço dos samurais do Período Tokugawa: "No cimo da onda / A gaivota espera / A dádiva do $\operatorname{mar}^{219}$ ”. O poeta não recusa a ironia e a

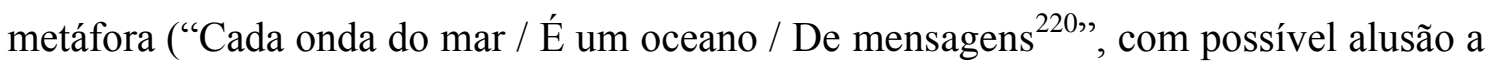
Fernando Pessoa) e parodia provérbios, ditos populares e sentenças bíblicas com humor oswaldiano ("Pelo mar / Fomos / Pelo mar somos ${ }^{221 ",}$, poema com ecos especulares do estilo anafórico dos textos atribuídos ao rei Salomão).

De frente para o mar é uma coletânea poética "tradicional", que apresenta poemas de boa fatura, mas não pretende inovar a linguagem poética, no sentido de Ana Hatherly e Melo e Castro; também não é uma antologia canônica, que faça o rastreamento da história do haicai em Portugal, desde Wenceslau de Moraes até Yvette Centeno (ou autores mais jovens, como João Rasteiro). É o registro de um momento da criação poética em Portugal, uma radiografia do diálogo presente entre a poesia portuguesa e o influxo da cultura japonesa, definição que poderíamos estender também a outra antologia, mais recente, organizada por Pedro Miguel Salvado: Sombra branca (Câmara

\footnotetext{
${ }^{217}$ Idem, 133.

${ }^{218}$ Idem, 83.

${ }^{219}$ Idem, 106.

${ }^{220}$ Idem, 97.

${ }^{221}$ Idem, 101.
} 
Municipal do Fundão, 2013). No texto de apresentação ao volume, A tecer o coração de uma cereja, escreve Paulo Fernandes:

O projeto artístico de Sombra branca surge no contexto de mais uma edição da Festa da Cereja da Freguesia de Alcangosta (...) Sombra branca, ao conjugar a palavra com a imagem, assume a cerejeira não apenas como uma árvore tópica da atual paisagem serrana local, mas também como uma metáfora lenhosa que estabelece e possibilita o surgimento de vínculos com outras culturas e geografias.

Este constitui, aliás, o nosso propósito: convocar para este evento eixos culturais e econômicos de outros pontos cardeais do mundo que venham e se apresentem neste periférico ocidental da velha Europa.

Sombra branca, ao reunir 14 haikus de criadores peninsulares e outras tantas pinturas na técnica oriental sumi-ê, é uma despretensiosa reverência ao povo e à cultura japonesa, representadas nesta edição do Festival da Cereja pelo nosso convidado de honra, Sua Excelência o Embaixador do Japão em Portugal, Dr. Nobutaka Shinomiya.

(SALVADO, 2013: 7-8)

O projeto gráfico deste caderno de haicais privilegia o espaço em branco da página e o diálogo entre poesia e pintura, com a inserção dos trabalhos de sumi-êe executados por Miguel Elías. A unidade estética do livro é reforçada também pelo signo da estação do ano (kigo) presente em todos os poemas: a cereja ou a cerejeira, árvore nacional do Japão. Conforme escreve Pedro Miguel Salvado: a cerejeira é o "símbolo da efemeridade da vida terrena (...). Predizendo o termo do Inverno e o renascimento de cada Primavera, as cerejeiras floridas são para os japoneses nascente de esperança, de alegria, de comunhão e de encontro com a natureza" (SALVADO, 2013: 11). Sobre ela, o poeta Den Sujetu (1633-1698) escreveu o seguinte poema: "Floresce a cerejeira / só para mostrar ao mundo / seu breve florir? ${ }^{222 "}$ (idem). Sob o signo dessa árvore admirada por artistas, guerreiros e camponeses, Sombra branca reúne 14 poetas da Península Ibérica, desde nomes conhecidos como Casimiro de Brito e Albano Martins até autores recentes, como João Rasteiro e Maria do Sameiro Barroso. Cada haicai é apresentado em uma página, nos idiomas português, espanhol e japonês. A respeito das traduções,

\footnotetext{
${ }^{222}$ A autoria da tradução não é indicada no livro.
} 
escreve o organizador da obra, Pedro Miguel Salvado: “As respirações de Sombra branca foram vertidas ao japonês religando-se, assim, àquela que é a sua enigmática e límpida fonte civilizacional original: a essa densa e profunda cartografia poética, filosófica e linguística pautada por outros ritmos e sentires aqui revisitada" (idem, 11). Como pequena amostragem de Sombra branca, citamos os seguintes haicais:

A primavera ofereceu

ao verão um rubro

colar de cerejas.

\section{Albano Martins \\ Vermelho verão. \\ Cerejas maduras \\ Campo que sangra.}

\section{Carlos Aganzo}

Agitam-se as folhas

da cerejeira - frases leves

escritas pelo vento.

\section{Casimiro de Brito}

Uivo de lobos, cerejas do homem, um deus pasmado.

\section{João Rasteiro}

Cinco cerejas argolas sem som: seda escarlata.

\section{Verônica Amat}

A primeira composição, de Albano Martins, apresenta vocabulário simples, dicção enxuta e um jogo bem-humorado com a referência sazonal, duplicada (primavera / verão) e transformada em personagem de prosopopeia. A segunda peça, de Carlos Aganzo, é ainda mais metafórica ("Vermelho verão", “campo que sangra"), aproximando-se de certo rebuscamento ornamental próprio da escola de Teitoku; o mesmo elemento metafórico é verificado no poema de Casimiro de Brito ("frases leves / escritas pelo vento"), em nítido afastamento da fotografia do cotidiano preconizada 
pelos mestres japoneses. Há nestas composições uma tentação de "lirismo", de incorporação da imagética e da subjetividade ocidental, ainda mais evidente nas peças seguintes, de João Rasteiro ("um deus pasmado") e Verônica Amat ("argolas sem som”). A inevitável transformação do haicai, após sua incorporação nas literaturas ocidentais, torna flexíveis as regras composicionais e alarga o repertório temático e de recursos formais; uma questão que poderia ser apresentada por algum estudioso mais ortodoxo, defensor do modelo canônico formulado por Shiki no século XIX (medidas métricas de 5-7-5 sílabas, referência sazonal e ao local em que foi escrito o poema), é a seguinte: em que medida podemos considerar tais poemas como haicais? Não serão apenas versos escritos em forma de terceto? A pergunta, considerada a partir do modelo tradicional do haicai, já traz em si mesma a resposta: não, os poemas escritos pelos autores portugueses não são haicais, gênero talvez irrealizável plenamente em outra língua diferente do japonês. Se adotarmos um ponto de vista menos ortodoxo, defendido, por exemplo, por autores brasileiros como Paulo Leminski e Alice Ruiz, a resposta seria outra: sim, são haicais, reinventados em outra língua, outra tradição cultural, porém mantendo elementos construtivos como a brevidade, a relação com a natureza, a simplicidade, o humor, a concisão. Numerosos autores brasileiros e portugueses publicam antologias e obras individuais em que reivindicam o gênero haicai, considerado modalidade literária já integrante das literaturas ocidentais. Para nós, no entanto, ambas as respostas são insuficientes, porque a própria pergunta talvez seja irrelevante: ao longo deste trabalho, quisemos discutir a recepção e transformação criativa de elementos estéticos e culturais da poesia japonesa nas obras de autores portugueses do século $\mathrm{XX}$, sem a pretensão de defender a pureza de qualquer gênero poético. O que surgiu dessa mescla, em nossa opinião, já não é a continuidade da poesia japonesa em outro idioma, mas sim a própria poesia portuguesa alimentada e estimulada 
por outro(s) repertório(s), em direção a um universalismo que talvez seja a melhor definição da poesia contemporânea. 


\section{CONCLUSÃO}

A recepção criativa da poesia japonesa em Portugal desenvolveu-se na segunda metade do século XX, fortemente influenciada pelas pesquisas realizadas pelos movimentos de vanguarda, especialmente a Poesia Experimental Portuguesa $(P O-E X)$, à qual estavam ligados autores como Herberto Helder, Ana Hatherly e E. M. de Melo e Castro. Os poetas portugueses, fascinados pela visualidade, concisão, ambiguidade, humor, lógica não-aristotélica e sobretudo pela técnica de montagem do ideograma, realizaram experimentos inventivos como os Mapas da imaginação e da memória de Ana Hatherly ou os Infopoemas de Melo e Castro, nos quais notamos também a influência da Poesia Concreta e dos estudos realizados por Fenollosa, Ezra Pound e Octavio Paz. A recepção portuguesa, portanto, não é um movimento erudito de natureza acadêmica ou museológica, centrado no estudo do idioma, história e cultura do Japão, mas uma atividade de natureza criativa, que nasce do encantamento pelas linguagens artísticas japonesas - além da poesia, a caligrafia e a pintura, sobretudo -, lidas por uma ótica que se sabe parcial e cosmopolita. O que motiva os poetas portugueses não é a imitação das formas literárias canônicas praticadas no Japão do século XVII e sim o diálogo inventivo que percebe a íntima relação entre poesia, gestualidade, grafismo e a importância do pensamento analógico para a expressão poética. A tradição literária do Japão é assim traduzida - ou reinventada - à luz do presente para a fundação de outra tradição, aquela que transita entre diversos repertórios, fronteiras, idiomas e referências, à margem da margem (para citar uma expressão cara ao poeta brasileiro Augusto de Campos). Nesse sentido, a própria tradução de haicais japoneses por Herberto Helder e Casimiro de Brito adquire caráter criativo, como heteronímia ou máscara dramática. $\mathrm{O}$ próprio Casimiro de Brito reconhece que "A poesia é intraduzível, e a minha tentativa de verter para o português, de fazer poesia a partir dos haicais japoneses, sem lhes 
roubar a magia, o clímax oriental é, reconheço-o, demasiado arriscada. Penitencio-me dizendo que foi uma tentação, e considero estes poemas breves um pouco como poesia minha" (BRITO, 1962: 10). Assim, ao longo deste trabalho, consideramos as traduções realizadas pelos autores portugueses como parte de seu próprio trabalho poético.

No primeiro capítulo da tese, de visada diacrônica, apresentamos um breve resumo da história e das formas poéticas praticadas no Japão desde a clássica antologia Manyoshu, publicada durante o Período Heian (794-1192), até a codificação do haicai por Masaoka Shiki (1867-1902). Abordamos as técnicas de composição do tanka, do renga, as diferentes escolas de haicai, os princípios da filosofia da arte que orientaram a poesia japonesa e a relação entre poesia, pintura e caligrafia, tópico que será de sumo interesse para os poetas portugueses estudados ao longo do presente trabalho.

No segundo capítulo é apresentado um relato do intercâmbio cultural e comercial desenvolvido entre Portugal e Japão a partir do século XVI, quando os primeiros missionários são enviados às ilhas japonesas. Registramos os textos produzidos por autores portugueses no período da evangelização, como os relatos de viagem de Luís Fróis e as obras do padre João Rodrigues, entre elas o Vocabulário da Lingoa de Iapam (1603) e a Arte da lingoa de Iapam (1604), em que se encontram as primeiras referências ao haicai registradas na literatura portuguesa. Os conflitos entre os missionários cristãos e as autoridades japonesas merecem a nossa atenção neste capítulo, pois motivaram a expulsão de todos os estrangeiros pelo xogum Tokugawa e o isolamento do Japão, que restringiu o comércio à ilha de Nagasaki, onde apenas os chineses e os holandeses estavam autorizados a trazer os seus produtos. O intercâmbio cultural com os países europeus seria retomado apenas na segunda metade do século XIX, com a Restauração Meiji, quando tem início um novo capítulo na história das relações entre o Japão e Portugal. O personagem-chave desse período é o diplomata, 
militar e escritor português Wenceslau de Moraes (1854-1929), que exerceu o cargo de cônsul no Japão, tendo inclusive adotado suas vestimentas, idioma e hábitos alimentares. O escritor português converteu-se ao zen-budismo, casou com uma japonesa e passou os seus últimos anos em Tokushima, após ter escrito 14 obras sobre a cultura japonesa, entre as quais se destacam $O$ culto do chá, Dai Nippon e Relance da alma japonesa. Wenceslau de Moraes foi o primeiro autor português a traduzir e comentar haicais em nosso idioma, além de abordar diferentes aspectos da cultura japonesa, incluindo a pintura, escultura, arquitetura, religião, ética, política e história.

Após o falecimento de Wenceslau de Moraes, o principal estudioso e divulgador da cultura japonesa em Portugal será outro diplomata, Armando Martins Janeira (19141988), autor de livros como Nô - teatro lírico japonês (1954), Caminhos da terra florida - a gente, a paisagem, a arte japonesa (1956), O teatro de Gil Vicente e o teatro clássico japonês (1967) e sobretudo O impacto português sobre a civilização japonesa (1970). No terceiro capítulo, analisamos as traduções realizadas por Janeira de obras dramáticas do repertório nô, especialmente Hagoromo (“O manto de penas”), que no Brasil foi "reimaginada" por Haroldo de Campos. A poética da tradução, aliás, é um dos temas centrais desse capítulo, em que discutimos também as versões de haicais japoneses efetuadas por Herberto Helder e Casimiro de Brito. Ao analisarmos diferentes concepções tradutórias - de Walter Benjamin, Jorge Luis Borges, Paulo Franchetti, Haroldo de Campos - não tivemos interesse meramente especulativo: nosso intuito foi o de iluminarmos o conceito da tradução como atividade inventiva, autoral. A visada diacrônica, adotada nos dois primeiros capítulos, cede lugar, aqui, à análise sincrônica: se a primeira corresponde ao historicismo, a segunda é "mais adequada e conatural ao projeto poético-artístico", conforme escreve Júlio Plaza, em seu livro A tradução intersemiótica (PLAZA, 2013: 7). Em lugar de recuperar o passado "como fetiche, como 
novidade, como conservadorismo, como nostalgia", a análise sincrônica permite que essa recuperação aconteça "de forma crítica, tomando aqueles elementos de utopia e sensibilidade que estão inscritos no passado e que podem ser liberados como estilhaços ou fragmentos para fazer face a um projeto transformativo do presente, a iluminar o presente" (idem). A sincronia acompanha nossa abordagem das traduções poéticas feitas por Casimiro de Brito e Herberto Helder e também o nosso mergulho nas obras desses autores, em que podemos verificar as impressões digitais de suas leituras dos poetas japoneses. No caso de Casimiro de Brito, percebemos as marcas da concisão, do paradoxo, da imagética, da justaposição de imagens; no caso de Herberto Helder, notamos a linguagem enigmática do koan, a ambiguidade, a lógica da metamorfose.

A poesia visual de Ana Hatherly e E. M. de Melo e Castro, por sua vez, recupera a iconicidade inerente à lírica japonesa, não apenas naquilo que ela tem de imitativo, mas sobretudo, em seu aspecto plástico: a mancha, o borrão, o ruído da tinta no papel, que desfigura deliberadamente os signos verbais, atribuindo a eles um relevo e contornos próximos à abstração. A caligrafia transforma a escrita poética numa arte que está além da mera semântica ou referencialidade, solicitando a participação sensível e inteligente do leitor, que é convidado a descobrir os seus próprios caminhos de leitura, uma vez que “seja qual for o tipo de escrita, visual, sonora, gestual, seja qual for o tipo de suporte, estamos sempre ante imagens codificadas" (HATHERLY, 2005: 107). Toda codificação, em consequência, implica o trabalho de decodificação "para que a comunicação se estabeleça, mesmo que essa comunicação deseje comunicar a sua incomunicabilidade" (idem). Em obras como Mapas da imaginação e da memória e Hand made, de Ana Hatherly, e os Ideogramas e Infopoemas de Melo e Castro, percebemos o nexo entre o princípio do ideograma (tal como compreendida por Fenollosa e Pound e transmitida 
aos poetas de vanguarda do período), o "encadeamento e interação de linha e mancha" que sugere "a lógica gráfica de pequenos acidentes e pausas inerentes à escrita" segundo Manuel Castro Caldas (in HATHERLY, 1992: 107), que permite uma aproximação com a caligrafia artística chinesa e japonesa, e ainda a presença da gestualidade, do registro da presença corporal do poeta/calígrafo, tal como acontece no expressionismo abstrato de Jackson Pollock. A dimensão visual da escrita está presente ainda nos textos poéticos de Albano Martins, que alia a extrema concisão ao alinhamento assimétrico de palavras e frases na página, atribuindo ao poema um caráter ao mesmo tempo plástico e rítmico (procedimento adotado quase simultaneamente por outros poetas do período, como Calos de Oliveira em Micropaisagem e Haroldo de Campos em Lacunae).

Albano Martins, assim como Eugênio de Andrade, recebeu uma influência inicial da poesia breve grega e romana e só mais tarde entrou em contato com a lírica japonesa; o aparente anacronismo não descarta a aproximação de sua poética com a escrita de Bashô e seus discípulos, uma vez que neste capítulo adotamos a leitura sincrônica, que permite a comparação entre textos e autores de diferentes épocas, idiomas e países. A comparação não é gratuita, antes rege-se pelas afinidades que seriam posteriormente reconhecidas pelo próprio Albano Martins, autor do volume Com as flores do salgueiro, publicado em 1993, em homenagem ao tricentenário da morte de Bashô. Caso similar é o de Eugênio de Andrade, autor de formação eclética, leitor de Alceu, Safo, Rimbaud, Federico Garcia Lorca, que conheceu o haicai já em plena maturidade, quando tinha publicado boa parte de sua obra. Podemos mapear, na lírica inicial do poeta, diversos elementos que permitiriam uma análise sincrônica, feita em paralelo com os textos japoneses - como a métrica de redondilhas e as referências às estações do ano - e mais ainda nas obras posteriores à sua leitura de Bashô, autor que exerceu profunda influência em seu volume Pequeno formato, publicado em 1997. Estamos, portanto, no 
território da simultaneidade, da sincronia, e sob esse paradigma vamos ler também a obra de uma poeta mais recente, Yvette Centeno, autora do volume A Oriente, onde reúne nada menos que 80 haicais, escritos numa linguagem miscigenada, porosa a influxos ocidentais e orientais, do passado e do presente. O Japão reinventado em Portugal não é o território fechado ao mundo pelos Tokugawas, enclausurado em seus castelos e tradições imutáveis, mas um Japão sonhado, aberto a todas inovações de linguagem, com espírito de permanentes inquietação e metamorfose. 


\section{REFERÊNCIAS BIBLIOGRÁFICAS:}

\section{A) BIBLIOGRAFIA ATIVA:}

\section{HISTÓRIA DA CULTURA JAPONESA}

BRINKER, Helmut. O zen na arte da pintura. São Paulo: Pensamento, 1991.

BROERING, Alécio. Os 26 mártires do Japão. São Paulo: Loyola, 1983.

COLLCUTT, JANSEN e KAMAKURA. Japão. São Paulo: Edições Folio, 2008.

CORDEIRO, Renata. Viagem ao Japão. São Paulo: Landy Editora, 2004.

DAVIS, F. H. Mitos e lendas do Japão. São Paulo: Landy, 2004.

DESHIMARU, Taisen. A tigela e o bastão. São Paulo: ed. Cultrix, 1983.

FRELLESVIG, Bjarke. A history of the japanese language. Cambridge University Press, 2010.

GONÇALVES, Ricardo M. Textos budistas e zen-budistas. São Paulo: Cultrix, 1995.

GIROUX, Sakae M. Zeami: cena e pensamento nô. São Paulo: Perspectiva, 2012.

HAMMITZSCH, Horst. O zen na arte da cerimônia do chá. São Paulo: Pensamento, 1993.

HERRIGEL, Eugen. A arte cavalheiresca do arqueiro zen. São Paulo: Pensamento, 1989. , Eugen. O caminho zen. São Paulo: Pensamento, 1990.

HERRIGEL, Gusty L. O zen na arte da cerimônia das flores. São Paulo: Brasiliense, 1995.

KATO, Shuichi. Tempo e espaço na cultura japonesa. São Paulo: Estação Liberdade, 2012.

LISBOA, Luiz Carlos, e ARAKAKI, Mara Rúbia. Namban - O dia em que o Occidente descobriu o Japão. São Paulo: Alianza Cultural Brasil-Japão / Estação Liberdade, 1993.

KONDER, Alexandre. História do Japão. Rio de Janeiro: Editora do Século XX, 1942.

KUSANO, Darci Yasuco. O que é teatro nô. São Paulo: Brasiliense, 1984.

SCHLOMBS, Adele. Hiroshige. Lisboa: Taschen, 2009.

SUZUKI, D. Teitaro. A doutrina zen da não-mente. São Paulo: Pensamento, 1989.

SUZUKI, Eico. Literatura japonesa (712-1868). São Paulo: Editora do Autor, 1979. Nô - Teatro Clássico Japonês. São Paulo: Editora do Autor, 1977. 
TAZAWA, Yutaka. História cultural do Japão - uma perspectiva. Ministério dos Negócios Estrangeiros do Japão, 1973.

WATTS, Alan. O espírito do zen. São Paulo: L\&PM, 2008.

YAMAZATO, Augusto. História ilustrada do Japão. São Paulo: ed. Cinco Cores, s/d.

\section{A ARTE DA CALIGRAFIA CHINESA E JAPONESA}

ADDISS, Stephen. The art of zen. Paintings and callygraphy by japanese monks 16001925. New York: Library of Congress, 1989.

NAKATA, Yujiro. The art of japanese calligraphy. New Cork / Tokio: Weatherhill / Heibonsha, 1973.

SAITO, Cecília Noriko Ito. O shodô, o corpo e os novos processos de significação. São Paulo: Annablume, 2004.

VÁRIOS AUTORES. Mestres do sho contemporâneo - Caligrafia artística japonesa. São Paulo: MASP / Consulado Geral do Japão / Fundação Japão / São Paulo Shimbun / Bunkyo, 2008.

\section{POESIA JAPONESA TRADUZIDA PARA LÍNGUAS OCIDENTAIS}

\section{1 - Para o português}

AKIKO, Yosano. Descabelados. Brasília: Editora Universidade de Brasília, 2007. Tradução: Donatella Natili e Álvaro Faleiros.

BASHÔ, Mstsuo. Sendas de Oku. São Paulo: Roswitha Kempf Editores, 1983. 1997. Trilha estreita ao confim. Trad.: Alberto Marsicano. São Paulo: Iluminuras,

BRITO, Casimiro de. Poemas orientais. Faro, 1962. . Poesia japonesa. Separata da Revista de poesia Limiar n. 5. Porto, 1995.

CAMPOS, Haroldo de. Hagoromo de Zeami. São Paulo: Estação Liberdade, 1993.

FRANCHETTI, Paulo, DOI, Elza Taeko e DANTAS, Luiz. Haikai. Antologia e história. $1^{\text {a }}$. edição: Campinas: Editora da Universidade Estadual de Campinas, 1990.

. Haikai. Antologia e história. 4a. edição: Campinas: Editora da Universidade Estadual de Campinas, 2012.

HELDER, Herberto. O bebedor nocturno. Lisboa: Assírio \& Alvim, 2010.

JANEIRA, Armando Martins. Nô. Tóquio, 1954.

LEMINSKI, Paulo. Bashô, A lágrima do peixe. São Paulo: ed. Brasiliense, 1983. MARSICANO, Alberto. Haikai. São Paulo: Editora Oriento, 1988. 
MENDONÇA, Maurício Arruda. Trilha forrada de folhas. Nenpuku Sato, um mestre de haikai no Brasil. São Paulo: Ciência do Acidente, 1999.

PIGNATARI, Décio. 31 poetas, 214 poemas. São Paulo: Companhia das Letras, 1996.

RUIZ, Alice. Dez hai kais. Florianópolis: Editora Noa Noa, 1981.

SENA, Jorge de. Poesia de 26 séculos. Porto: Editorial Inova Limitada, 1971, 2 vols.

\section{2 - Para o francês:}

ATLAN, Corinne, e BIANU, Zéno. Haiku: anthologie du poème court japonais. Paris: Gallimard, 2002.

. Le poème court japonais d'aujourd'hui. Paris: Gallimard, 2007.

BRUNEL, Henri. Les haikus. Paris: Librio, 2005.

COYAUD, Maurice. Fourmis sans ombre. Le livre du haiku. Paris: Phébus, 2001.

. Tanka, haiku, renga: le triangle magique. Paris: Belles Lettres, $1996 .$.

MERCIER, Catherine-Jeanne. Haikus. Paris: Seuil, 2003.

MUNIER, Roger. Miroirs de la nature: recueil de haikus. Paris: Seuil, 2012.

. Haikus des quatre saisons. Paris: Seuil, 2010.

. Haiku. Paris: Fayard, 2000.

\section{3 - Para o inglês:}

BLYTH, R. H.. Haiku (quatro volumes). Tóquio: Hokuseido Press, 1981/1982.

\section{4 - Para o espanhol:}

PAZ, Octavio. Versiones y diversiones. Tabasco: Editorial Joaquín Mortiz, 1974.

\section{LITERATURA PORTUGUESA MODERNA E CONTEMPORÂNEA}

ANDRADE, Eugênio de. Antologia breve. Lisboa: Moraes Editores, 1980. . Poesia. Lisboa: Fundação Eugênio de Andrade, 2000.

ANDRESEN, Sophia de Mello Breyner. Ilhas. Lisboa: Texto Editora, 1989.

BRANCO, José Fernando Castro. Poética do sensível em Albano Martins. Lisboa: Roma Editora, 2004.

BRITO, Casimiro de. À sombra de Bashô. Faro: colecção do Grito Claro, 2001.

Apenas um ruído (antologia de poesia japonesa). In: Nova Renascença $\mathrm{n}$. 60/63. Porto: Inverno / Outono, 1996. 
Zoo mínimo (antologia de haicais de Kobayashi Issa). Lisboa: PEN, Folhas soltas, n. 3, 1996.

. Na via do mestre. Guimarães: Pedra Formosa, 2000.

CENTENO, Yvette. A oriente. Lisboa: Editorial Presença, 1998.

HATHERLY, Ana. 463 tisanas. Lisboa: Quimera, 2006.

O mestre. Rio de Janeiro: Sette Letras, 2006

PO.EX - Teóricos e documentos da poesia experimental portuguesa (com E.

M. de Melo e Castro). Lisboa: Moraes Editores, 1981.

A experiência do prodígio - bases teóricas e antologia de textos-visuais portugueses dos séculos XVII e XVIII. Lisboa. Imprensa Nacional - Casa da Moeda, 1983. A casa das musas. Lisboa: Editorial Estampa, 1995.

1992 Obra visual: 1960-1990. Lisboa: Fundação Calouste Gulbenkian, Mapas da imaginação e da memória. Lisboa: Moraes Editores, 1973.

HELDER, Herberto. Os passos em volta. Rio de Janeiro: Azougue Editorial, 2005.

MARTINS, Albano. Com as flores do salgueiro. Porto: Universidade Fernando Pessoa, 1995.

MELO E CASTRO, E. M. Antologia efémera. Rio de Janeiro: Lacerda editores, 2000.

SALVADO, Pedro Miguel (org.). Sombra branca. Câmara Municipal do Fundão, 2013.

\subsection{Antologias de haicaístas portugueses}

BRITO, Casimiro. Uma rã que salta - Homenagem a Bashô. Porto: ed. Limiar, 1995.

RODRIGUES, David. De frente para o mar. Coimbra: Palimage, 2010.

SALVADO, Pedro Miguel. Sombra branca. Câmara Municipal do Fundão: 2013),

\section{RELATOS DE VIAJANTES EUROPEUS E BRASILEIROS}

AZEVEDO, Aluísio. O Japão. São Paulo: Roswitha Kempf, 1984.

COOPER, S. J. Michael. Rodrigues, o intérprete. Um jesuíta português no Japão e na China. Lisboa: Quetzal Editores, 1994.

JANEIRA, Armando Martins. O impacto português sobre a civilização japonesa. Lisboa: Publicações Dom Quixote, 1988. 
MORAES, Wenceslau. Relance da alma japonesa. Lisboa: Parceria A. M. Pereira, 1924. LTDA., 1924.

Relance da história do Japão. Porto: Empresa industrial gráfica do Porto . Cartas do Japão. Porto: Portugal-Brasil, 1928.

. Traços do Extremo Oriente. Lisboa: Livraria Brasileira, 1946.

Fala a lenda japonesa. Lisboa: Cotovia, 1993.

. Cartas do Extremo Oriente. Lisboa: Fundação Oriente, 1993.

Fernão Mendes Pinto no Japão. Lisboa: VEGA, 1993.

. Daí Nippon. Rio de Janeiro: Nórdica, s/d.

. O culto do chá. Lisboa: Vega, 1996.

Moeda, 2006.

Ó-Yoné e Ko-Haru. Lisboa: Instituto Camões / Imprensa Nacional - Casa da

PINTO, Fernão Mendes. Peregrinação. Lisboa: Livraria Sá da Costa, 1961.

POLO, Marco. As viagens de Marco Polo. São Paulo: Martins Fontes, 1997.

\section{TEORIA LITERÁRIA E OBRAS DE CARÁTER GERAL}

ALENCAR, Ana, LEAL, Izabela, e MEIRA, Caio (org.). Tradução literária: a vertigem do próximo. Rio de Janeiro: Azougue Editorial, 2011.

ALLETON, Viviane. Escrita chinesa. Porto Alegre: L\&PM, 2010.

ALMEIDA, Guilherme de, e VIEIRA, Trajano. Três tragédias gregas. São Paulo: Perspectiva, 1997;

BARBOSA, João Alexandre. As ilusões da modernidade. São Paulo: Perspectiva, 2005.

BARTHES, Roland. O império dos signos. São Paulo: Martins Fontes, 2007.

BENJAMIN, Walter. Escritos sobre mito e linguagem. São Paulo: Duas Cidades / Editora 34, 2011.

BONVICINO, Régis e FENG, Yao. Um barco remenda o mar - Dez poetas chineses contemporâneos. São Paulo: Martins Editora Livraria LTDA., 2007.

BORGES, Jorge Luis. Dezessete haiku. Tradução: Amálio Pinheiro. São Paulo: Arte PauBrasil, 1990.

. Esse ofício do verso. São Paulo: Companhia das Letras, 2000.

. Discussão. São Paulo: Difel, 1985.

Obras completas, vol. II. São Paulo: Editora Globo, 1999. 
CAMPOS, Augusto de. Verso Reverso Controverso. São Paulo: Perspectiva, 1978a.

CAMPOS, Augusto e Haroldo de, PIGNATARI, Décio, GRUNEWALD, José Lino e FAUSTINO, Mário. Ezra Pound - Poesia. Brasilia: Editora Hucitec / Editora Universidade de Brasília, 1983.

CAMPOS, Haroldo de. A operação do texto. São Paulo: Perspectiva, 1976.

. A arte no horizonte do provável. São Paulo: Perspectiva, 1977.

. Ideograma. São Paulo, Edusp, 2000.

. Metalinguagem e outras metas. São Paulo: Perspectiva, 2004.

Transcriação (org.: Marcelo Tápia e Thelma Médici Nóbrega). São Paulo:

Perspectiva, 2013.

Depoimentos de oficina. São Paulo: Unimarco, 2002.

. Dante Aligheri - 6 cantos do Paraíso. São Paulo: Editora Fontada LTDA / Istituto Italiano di Cultura, 1978b.

. Crisantempo. São Paulo: Perspectiva, 1997.

Deus e o Diabo no Fausto de Goethe. São Paulo: Perspectiva, 1981.

CAMÕES, Luís de. Os lusíadas. Edição crítica de Francisco da Silveira Bueno. Rio de Janeiro: Edições de Ouro, 1999.

CANTINHO, Maria João. In Zunái, Revista de Poesia e Debates n. XXVI. São Paulo, março de 2013.

CAPPARELLI, Sérgio, e YUQI, Sun. Poemas clássicos chineses (Li Bai, Du Fu e wang Wei). Porto Alegre: L\&PM, 2012.

CAPRA, Fritjof. O tao da física. São Paulo: ed. Pensamento, 1989.

CARVALHO, Daniela de. Nambanjin: sobre os portugueses no Japão. Lisboa: revista Antropológicas n. 4, 2000. http://revistas.rcaap.pt/antropologicas/article/view/924/726

CARVALHO, Gil de. A propósito de poesia - Oriente e Ocidente. In Revista Colóquio I Letras, n. 142, pp. 200-203.

COSTA, Horácio. Satori. São Paulo: Iluminuras, 1989.

DERRIDA, Jacques. Torres de Babel. Belo Horizonte: Editora da UFMG, 2002.

EAGLETON, Terry. Teoria da literatura - uma interpretação. São Paulo: Martins Fontes, 2006.

ECO, Umberto. Obra aberta. São Paulo: Perspectiva, 1976. . Os limites da interpretação. São Paulo: Perspectiva, 2008. 
FALEIROS, Álvaro. Traduzir o poema. São Paulo: Ateliê Editorial, 2012.

GUEDES, Maria Estela. A obra ao rubro de Herberto Helder. São Paulo: Escrituras, 2010.

FRANCHETTI, Paulo. O haicai no Brasil. In Poesia Sempre n. 17, ano X, dezembro / 2002, pp. 23-40.

Edusp, 2001.

Nostalgia, exílio e melancolia. Leituras de Camilo Pessanha. São Paulo:

Wenceslau de Moraes e o haikai. In Revista Colóquio / Letras n. 110 / 111, julho / 1989, pp. 50-59.

GAUDIOSO, Tomoko. Wabi, sabi, wasabi, warabi. Jornal Memai, n. 7, Inverno /2011.

HICHMEH, Yuri Sócrates Saleh. Império e xogunato no Japão. Jornal Memai, n. 8, Primavera $/ 2011$.

JACOTO, Lílian, e MAFFEI, Luís (org.). Soldado aos laços das constelações. Bauru: Lumme Editor, 2011.

KHAYYAM, Omar. Rubayat. Tradução: Eugênio Amado. Rio de Janeiro: Livraria Garnier, 1999.

KEROUAC, Jack. Livro de haicais. Tradução: Claudio Willer. Porto Alegre: L\&PM, 2013.

LIMA, Luiz Costa. A literatura e o leitor. São Paulo: Paz e Terra, 2011.

1983. V. II.

Teoria da literatura em suas fontes. Rio de Janeiro: Francisco Alves,

MALLARMÉ, Stéphane. Igitur ou A loucura de Elbehnon. Tradução: José Lino Grunewald. Rio de Janeiro: Nova Fronteira, 1984.

MOISÉS, Massaud. Dicionário de termos literários. São Paulo: ed. Cultrix, 2004.

MORAIS, Fernando. Corações sujos. A história da Shindo Renmei. São Paulo: Companhia das Letras, 2000.

MOTTA, Leda Tenório da. Céu acima - para um tombeau de Haroldo de Campos. São Paulo: Perspectiva, 2006.

NAGAE, Neide. Mil folhas para Geny. Jornal Memai, n. 8, Primavera /2011.

PAZ, Octavio. Signos em rotação. São Paulo: Perspectiva, 1996.

PESSANHA, Camilo. Clepsidra. Organização, apresentação e notas de Paulo Franchetti. São Paulo: Ateliê Editorial, 2009.

Clepsidra. Apresentação crítica, notas e organização de Célia A. N. Passoni. São Paulo: Editora Núcleo, 1989. 
PIMENTEL, Luís Antônio. A poesia e suas demandas. In Poesia Sempre n. 17, ano X, dezembro / 2002, pp. 11-19.

RECKERT, Stephen. A desejada parte oriental na moderna poesia portuguesa. In Poesia Sempre n. 17, ano X, dezembro / 2002, pp. 45-63.

RIMBAUD, Artur. Uma temporada no inferno \& Iluminações. Tradução: Ledo Ivo. Rio de Janeiro: Francisco Alves, 1982. Poésies / Une saison en enfer / Illuminations. Paris: Gallimard, 1984.

RÓNAI, Paulo. Escola de tradutores. Rio de Janeiro: Livraria São José, 1956.

SANTOS, José da Cruz (coord.). Ensaios sobre Eugênio de Andrade. Porto: Edições ASA, 2003.

SARAIVA, Arnaldo. Introdução à poesia de Eugênio de Andrade. Lisboa: Fundação Eugênio de Andrade, 1995.

UNGARETTI, Giuseppe. Daquela estrela à outra. Tradução: Haroldo de Campos e Aurora Bernardini. São Paulo: Ateliê Editorial, 2003.

USUI, Chisato. Desenhando a palavra. In Poesia Sempre n. 17, ano X, dezembro / 2002 , pp. 21-22

VIEIRA, Primo. A propósito do hai-kai. In Revista Colóquio / Letras n. 49, maio / 1979, pp. 58-60. 
